\title{
Unsymmetrical Aryl(2,4,6-trimethoxyphenyl)iodonium Salts: One-pot Synthesis, Scope, Stability, and Synthetic Applications
}

\author{
Thomas L. Seidl, Sunil K. Sundalam, Brennen McCullough and David R. Stuart* \\ dstuart@pdx.edu \\ Department of Chemistry, Portland State University, Portland Oregon 97201, United States
}

\section{Supporting Information}

1. Design of Experiments (DoE)... S2

2. Qualitative light stability study... S9

3. Differential Scanning Calorimetry (DSC)... S10

4. In situ reaction temperature profiles... $\quad$ S11

5. ${ }^{1} \mathrm{H},{ }^{13} \mathrm{C},{ }^{19} \mathrm{~F}$ NMR spectra of new compounds... $\quad$ S12 


\section{Design of Experiments (DoE) information}

\subsection{Placket-Burmann Design with center points}

Plackert-Burman designs allow evaluation of main effects with relatively few experiments. In this case 12 experiments were required to study five factors and 5 center points were added.

\subsubsection{Summary of design (Table S1) and applicable model (Table S2).}

Table S1. ${ }^{a}$ Low and high levels are coded to -1 and +1 in order to assess the relative effect of each factor on \%yield. "Time 1" and "Time 2" refer to reaction times for "Stage 1" and "Stage 2", respectively.

\begin{tabular}{|c|c|c|c|c|}
\hline Factor & Description $^{b}$ & low level ${ }^{a}$ & center level $^{a}$ & high level $^{a}$ \\
\hline A & Conc. (M) & $0.1(-1)$ & $0.55(0)$ & $1 \quad(1)$ \\
\hline B & Time 1 (min) & $2(-1)$ & $16 \quad(0)$ & $30(1)$ \\
\hline $\mathrm{C}$ & Time 2 (min) & $2(-1)$ & $16 \quad(0)$ & $30(1)$ \\
\hline D & Temp. $\left({ }^{\circ} \mathrm{C}\right)$ & $25(-1)$ & $53 \quad(0)$ & $80(1)$ \\
\hline E & TMB (equiv) & $1 \quad(-1)$ & $2.0(0)$ & $3 \quad(1)$ \\
\hline
\end{tabular}

Table S2. Contribution of factors, non-aliased interactions and curvature to yield are shown (calculated with Design Expert software).

\begin{tabular}{|c|c|c|}
\hline Factor & Description & \%contribution \\
\hline $\mathbf{A}$ & Conc. (M) & 7.71 \\
\hline B & $\begin{array}{l}\text { Time } 1 \\
(\mathrm{~min})\end{array}$ & 19.35 \\
\hline $\mathrm{C}$ & Time 2 (min) & 0.12 \\
\hline D & Temp. $\left({ }^{\circ} \mathrm{C}\right)$ & 30.35 \\
\hline curvature & - & 31.94 \\
\hline E & TMB (equiv) & 2.77 \\
\hline $\mathrm{AB}$ & & 1.85 \\
\hline $\mathrm{AC}$ & & 1.09 \\
\hline $\mathrm{AD}$ & Interaction & 3.81 \\
\hline $\mathrm{AE}$ & Terms & 0.12 \\
\hline $\mathrm{BC}$ & & 0.03 \\
\hline $\mathrm{BE}$ & & 0.82 \\
\hline Pure error & - & 0.033 \\
\hline
\end{tabular}

\subsubsection{Identification of main effects}

Main effects are those factors that substantially contribute to yield and are included in subsequent experiment designs. Factors chosen as main effects are bolded in Table S2 and it can be seen that they make up for $\sim 90 \%$ of the measured response. The effect of each factor is visualized in Figure S1. The "equivalents of TMB" factor was rejected from subsequent work because its effect was inversely proportional to yield. Despite its low effect on yield, the reaction time of Stage 2 was included in subsequent experiment designs as it is an integral part of the iodonium salt preparation. 
Figure S1. Plots of effects for factors A, B, C, D, E (from left to right). In each plot the x-axis runs from the low to the high value and the $y$-axis from $0 \%$ to $100 \%$.
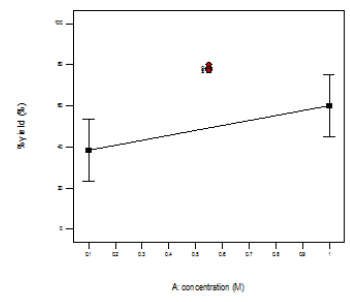

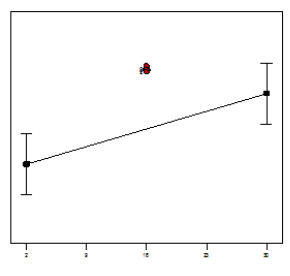

B. Trees (min)
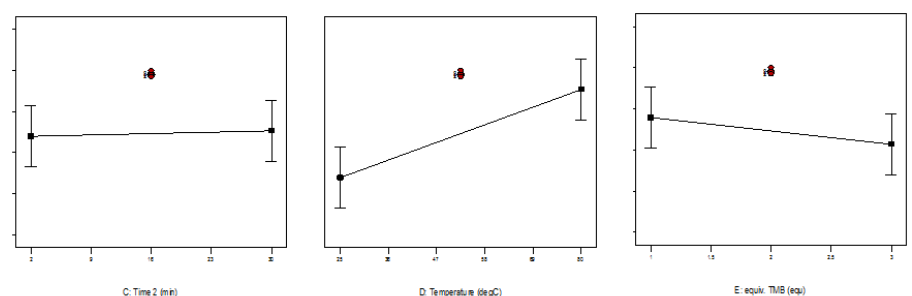

\subsection{Full Factorial Design}

Identification of interactions between variables is possible with this design. This design, with four factors, required sixteen experiments and was conducted on $0.2 \mathrm{mmol}$ scale of $\mathbf{1}$. It should be noted that studying factor $\mathrm{C}$ was optional as it was not a main effect, making the number of experiments required was lower.

\subsubsection{Summary of design (Table S3) and applicable model (Table S4).}

Table S3. Summary of factorial design.

$\begin{array}{llll}\text { Factor } & \text { Description }^{b} & \text { low level } & \\ \text { A } & \text { Conc. (M) } & 0.1(-1) & 1 \quad(1) \\ \text { B } & \text { Time 2 (min) } & 2(-1) & 30(1) \\ \text { C } & \text { Time 1 (min) } & 2(-1) & 30(1) \\ \text { D } & \text { Temp. }\left({ }^{\circ} \mathrm{C}\right) & 25(-1) & 80(1)\end{array}$

Table S4. Regressioin analysis of factorial study. Bolded rows were selected as model terms (see Table S5). Terms shown include all possible factors and interactions possible with the design model used.

Factor Description $\begin{aligned} & \text { Standardized } \\ & \text { Effect }\end{aligned} \begin{aligned} & \begin{array}{l}\text { Sum of } \\ \text { Squares }\end{array}\end{aligned} \%$ Contribution

$\begin{array}{llrrr}\text { A-Conc } & \text { Conc. }(\mathbf{M}) & \mathbf{2 0 . 2 7} & \mathbf{1 6 4 2 . 3 7} & \mathbf{1 0 . 9 3} \\ \text { B-Time 1 } & \text { Time 1 }(\mathbf{m i n}) & \mathbf{2 1 . 3 2} & \mathbf{1 8 1 7 . 6 0} & \mathbf{1 2 . 0 9} \\ \text { C-Time 2 } & \text { Time 2 }(\mathrm{min}) & -1.41 & 8.42 & 0.056 \\ \text { D-temperature } & \text { Temp. }\left({ }^{\circ} \mathbf{C}\right) & \mathbf{5 2 . 2 5} & \mathbf{1 0 9 1 8 . 6 8} & \mathbf{7 2 . 6 5} \\ \text { AB } & & \mathbf{3 . 3 7} & \mathbf{4 5 . 3 9} & \mathbf{0 . 3 0} \\ \text { AC } & & -0.55 & 1.18 & 7.87 \mathrm{E}-003 \\ \text { AD } & & \mathbf{6 . 0 4} & \mathbf{1 4 5 . 8 7} & \mathbf{0 . 9 7} \\ \text { BC } & & 1.4 & 7.97 & 0.053 \\ \text { BD } & & \mathbf{0 . 0 5 9} & \mathbf{0 . 0 1 4} & \mathbf{9 . 1 9 E - 0 0 5} \\ \text { CD } & & -2.01 & 16.64 & 0.11 \\ \text { ABC } & \text { Interaction } & 1.38 & 7.71 & 0.051 \\ \text { ABD } & \text { Terms } & \mathbf{- 1 0 . 1 9} & \mathbf{4 1 5 . 2 4} & \mathbf{2 . 7 6} \\ \text { ACD } & & 0.50 & 0.98 & 6.49 \mathrm{E}-003 \\ \text { BCD } & & 0.52 & 1.21 & 8.03 \mathrm{E}-003 \\ \text { ABCD } & & 0.34 & 0.54 & 3.57 \mathrm{E}-003\end{array}$




\subsubsection{Identification of interactions by regression analysis and ANOVA (Figure 1a).}

Table S5. Factors selected as model terms based on ANOVA. Factors that are not statistically significant are not included in the model unless required to support hierarcy, as with interaction term BD. Prob > F values of less than 0.0500 are statistically significant and those greater than 0.1 are not significant.

$\begin{array}{llrrrr}\text { Factor } & \text { Description } & \text { Sum of Squares } & \text { \% Contribution } & \text { F-value } & \begin{array}{c}\text { p-value } \\ \text { Prob }>\text { F }\end{array} \\ \text { A } & \text { Conc. }(\mathrm{M}) & 1642.37 & 10.93 & 298.02 & <0.0001 \\ \text { B } & \text { Time 1 }(\mathrm{min}) & 1817.60 & 12.09 & 329.82 & <0.0001 \\ \text { D } & \text { Temp. }\left({ }^{\circ} \mathrm{C}\right) & 10918.68 & 72.65 & 1981.30 & <0.0001 \\ \mathrm{AB} & & 45.39 & 0.30 & 8.24 & 0.0208 \\ \mathrm{AD} & & 145.87 & 0.97 & 26.47 & 0.0009 \\ \mathrm{BD} & \text { Interaction terms } & 0.014 & 9.19 \mathrm{E}-005 & 2.505 \mathrm{E}-003 & 0.9613 \\ \mathrm{ABD} & & 415.24 & 2.76 & 75.35 & <0.0001\end{array}$

\subsubsection{Evaluation of overall Factorial Model (Design Expert).}

Table S6. Statistical evaluation of model.

Results

\begin{tabular}{|c|c|c|c|c|}
\hline F-value & 388.83 & $\begin{array}{l}\text { p-value } \\
(\text { Prob > F })\end{array}$ & $<0.0001$ & $\begin{array}{l}\text { The model is significant and there a } \\
0.01 \% \text { chance this F-value could be } \\
\text { due to noise }\end{array}$ \\
\hline $\begin{array}{l}\text { Std. } \\
\text { Dev. }\end{array}$ & 2.35 & R-Squared & 0.9971 & \multirow{3}{*}{$\begin{array}{l}\text { Predicted and Adjusted R-Squared } \\
\text { values are }<0.2 \text { apart, indicating the } \\
\text { model is appropriate for the data } \\
\text { collected }\end{array}$} \\
\hline Mean & 45.69 & Adj. R-Squared & 0.9945 & \\
\hline $\mathrm{CV} \%$ & 5.14 & Pred R-Squared & 0.9883 & \\
\hline PRESS & 176.35 & Adeq Precision & 50.456 & $\begin{array}{l}\text { This model can be used to navigate the } \\
\text { design space due to sufficient signal- } \\
\text { to-noise ratio. }\end{array}$ \\
\hline
\end{tabular}

\subsubsection{Final model equation calculated by Design Expert.}

The model at this point has good value for prediction; however, optimization requires additional data points to allow for a higher order. Fortunately, this may be accomplished by adding sufficient data points to the existing factorial design results so that a quadratic model is possible. Effects of interactions are graphically described in Figures S2 through S4.

Equation in terms of coded factors:

$\%$ yield $=45.2+10.1 A+10.7 B+26.7 D+1.7 A B+3.0 A D+0.03 B D-5.0 A B D$ 
Equation in terms of actual factors - see plots in Figure S2:

\%yield $=-5.37-23.1 A-0.25 B+0.52 D+1.93 A B+0.78 A D+0.02 B D-0.032 A B D$

Figure S2. A) 3D-plot of factorial response at $\mathrm{T}=77{ }^{\circ} \mathrm{C}$, time $2=5 \mathrm{~min}$. B) Illustration of temperature/concentration interaction. The effect of changing concentration from $0.1 \mathrm{M}$ to $1 \mathrm{M}$ on yield is more pronounced at higher temperature (bottom).

\section{A)}

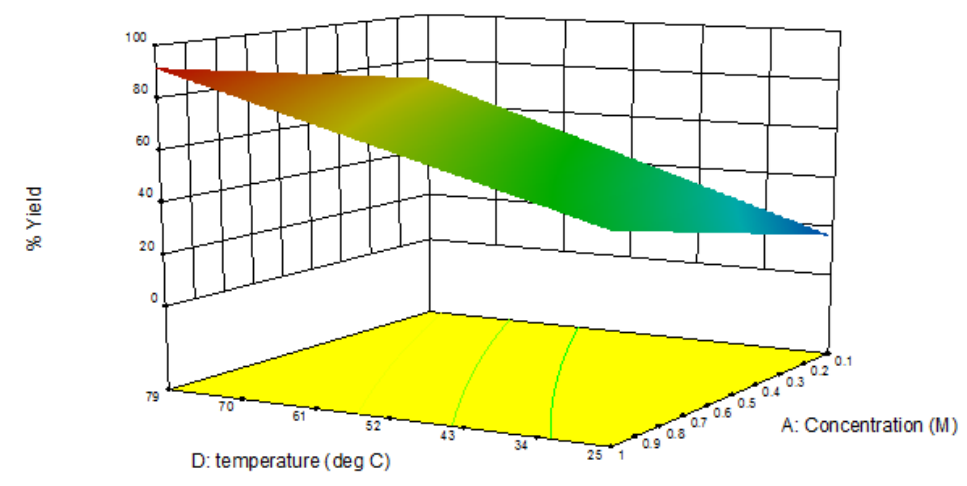

B)
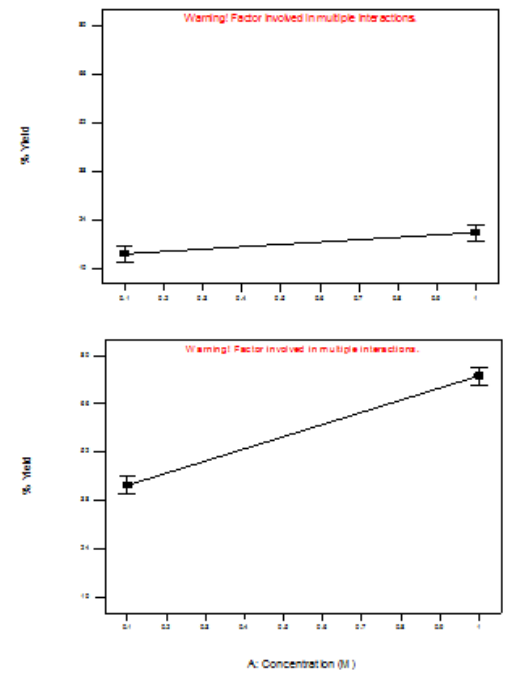

Figure S3. A) 3D-plot of factorial response at conc. $=1 \mathrm{M}$, time $2=5 \mathrm{~min}$. B) Illustration of temperature/time 1 interaction. The effect of changing temperature from $25{ }^{\circ} \mathrm{C}$ to $77{ }^{\circ} \mathrm{C}$ on yield is less pronounced at longer stage 1 time (bottom).

\section{A)}

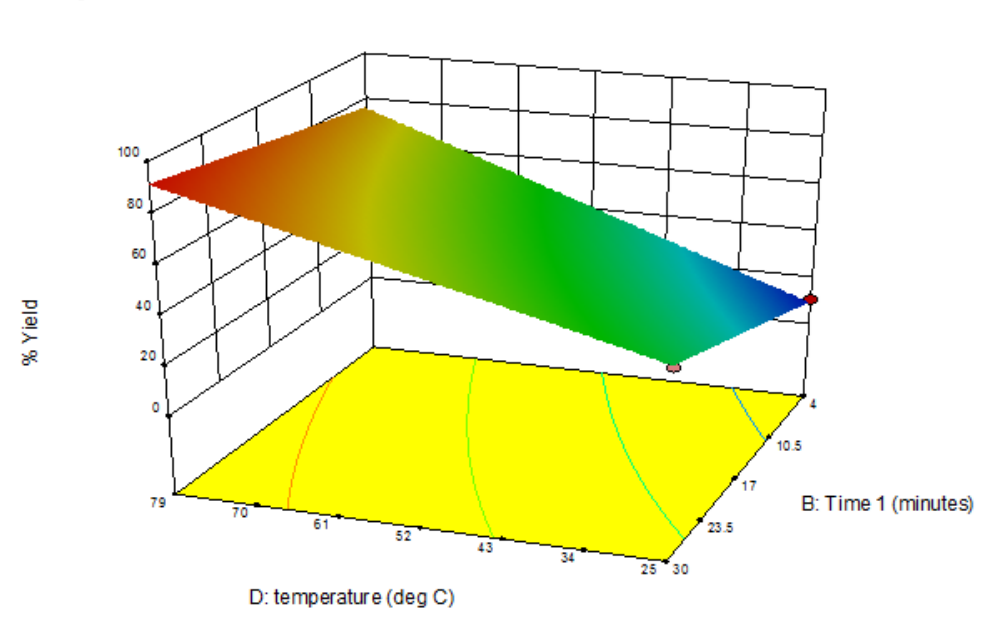

B

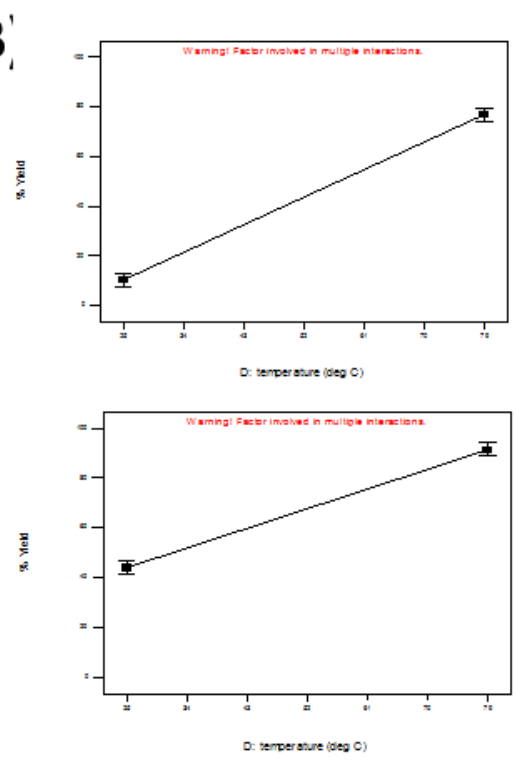


Figure S4. A) 3D-plot of factorial response at time $1=30 \mathrm{~min}$, time $2=5 \mathrm{~min}$. B) Illustration of concentration/time 1 interaction. The effect of changing concentration from $0.1 \mathrm{M}$ to $1 \mathrm{M}$ on yield is more pronounced at longer stage 1 time (bottom).
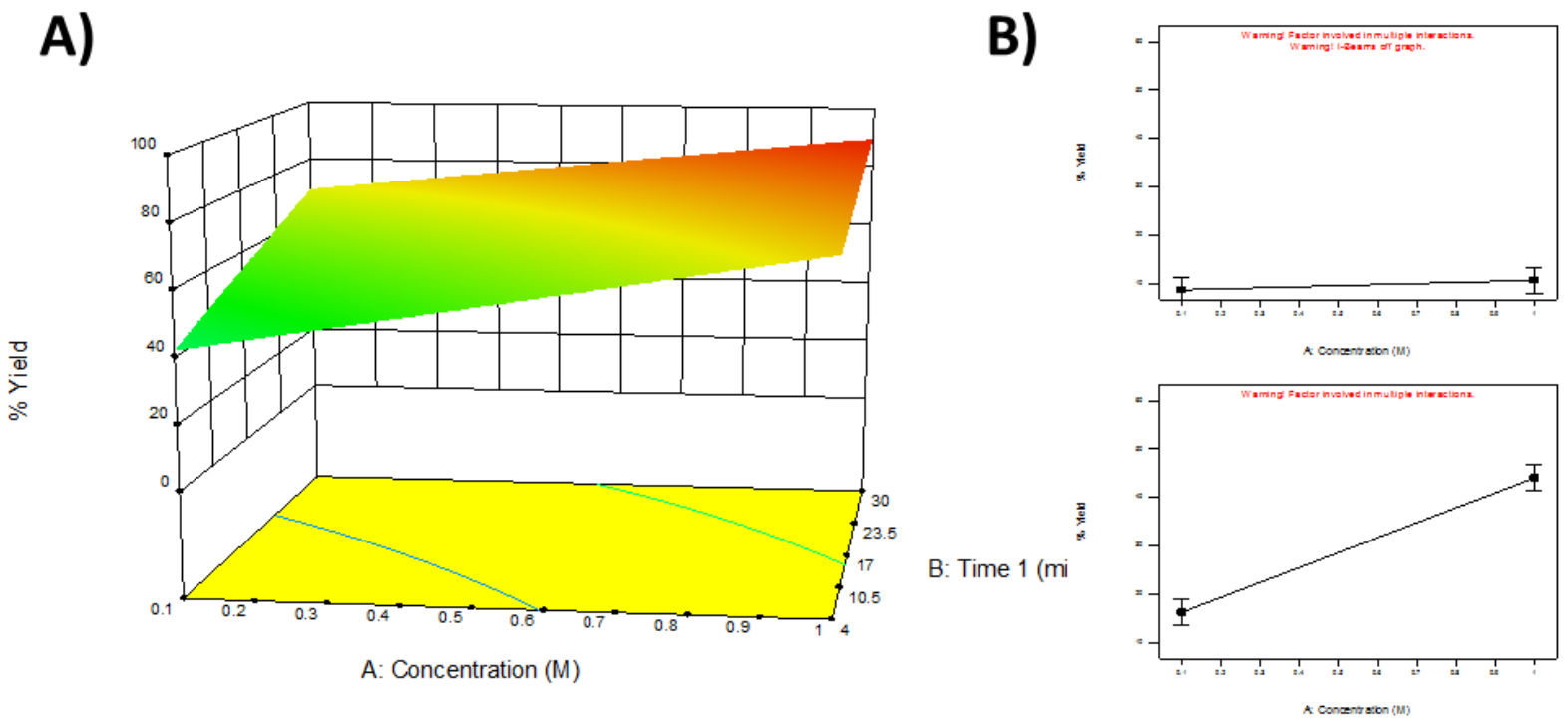

\subsection{Optimization via Response Surface}

\subsection{1.}

Results from the factorial design above are augmented with additional points necessary to apply a quadratic model. Ten additional points were needed to achieve the response surface in Figure 3. The additional points were applied in a face-centered design with respect to the factorial model discussed above. Additional points were then taken to confirm the model. Confirmation runs were performed in triplicate.

\subsubsection{Evaluation of overall Response Surface model (Design Expert)}

Table S7. Factors selected as model terms based on ANOVA.

\section{Factor}

A-Concentration

B-Time 1

D-temperature

$\mathrm{A}^{2}$

$\mathrm{D}^{2}$
Description

Conc. (M)

Time 1 (min)

Temp. $\left({ }^{\circ} \mathrm{C}\right)$

Quadratic terms
Sum of Squares

2067.46

1559.98

13732.11

291.92

1152.60
F-value

37.36

19.64

14.82

130.47

2.77 p-value Prob > F

$<0.0001$

0.0002

0.0009

$<0.0001$

0.1107 
Table S8. Statistical evaluation of model.

\begin{tabular}{|c|c|c|c|c|}
\hline \multicolumn{4}{|c|}{ Results } & Conclusion \\
\hline F-value & 37.36 & $\begin{array}{l}\text { p-value } \\
(\text { Prob > F })\end{array}$ & $<0.0001$ & $\begin{array}{l}\text { The model is significant and there a } \\
0.01 \% \text { chance this F-value could be } \\
\text { due to noise }\end{array}$ \\
\hline $\begin{array}{l}\text { Std. } \\
\text { Dev. }\end{array}$ & 10.26 & R-Squared & 0.8989 & \multirow{3}{*}{$\begin{array}{l}\text { Predicted and Adjusted R-Squared } \\
\text { values are }<0.2 \text { apart, indicating the } \\
\text { model is appropriate for the data } \\
\text { collected }\end{array}$} \\
\hline Mean & 54.85 & Adj. R-Squared & 0.8749 & \\
\hline CV\% & 18.7 & Pred R-Squared & 0.8247 & \\
\hline PRESS & 3833.68 & Adeq Precision & 18.578 & $\begin{array}{l}\text { This model can be used to navigate the } \\
\text { design space due to sufficient signal- } \\
\text { to-noise ratio. }\end{array}$ \\
\hline
\end{tabular}

Figure S5. Response surface. A) temperature $v s$ yield. B) Effect of temperature and concentration on yield at time $1=30 \mathrm{~min}$, time $2=5 \mathrm{~min}$.
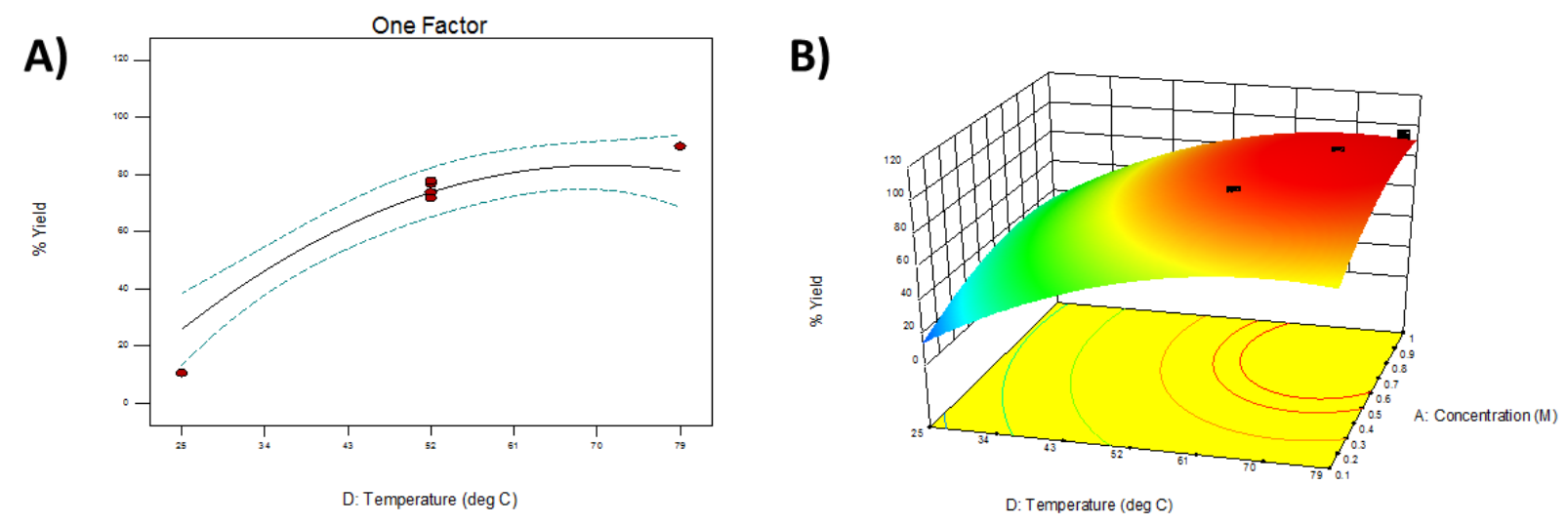

Figure S6. Response surface. A) time $1 v s$ yield. B) Effect of time 1 and concentration on yield at temperature $=77^{\circ} \mathrm{C}$, time $2=5 \mathrm{~min}$.

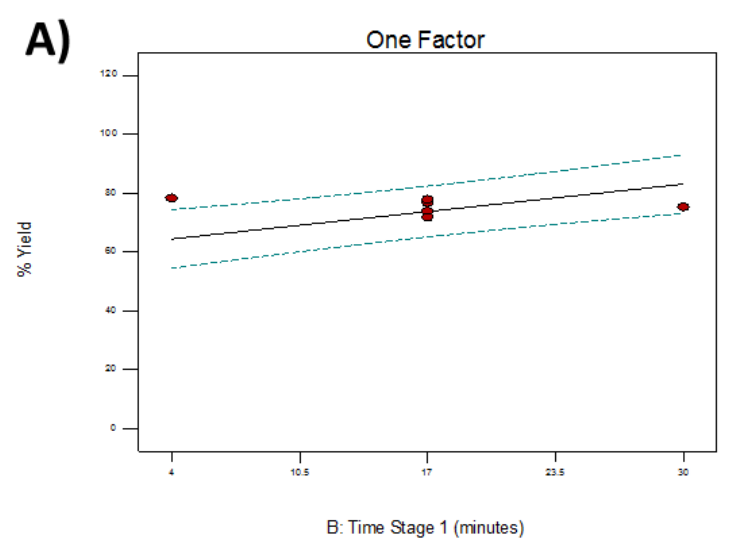

B)

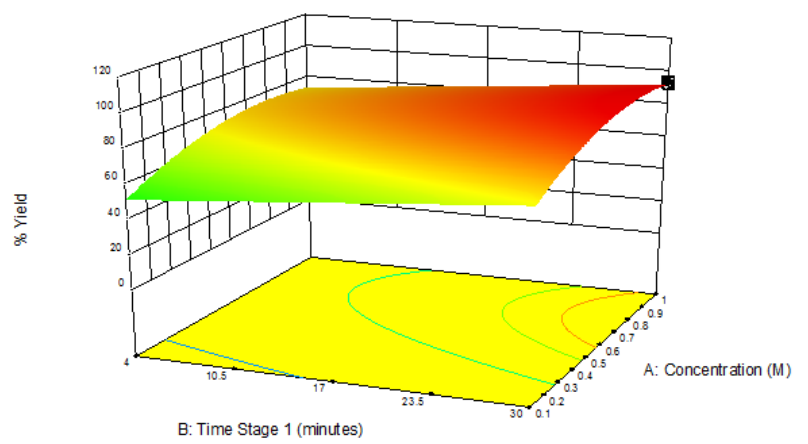


Figure S7. Response surface. A) concentration $v s$ yield. B) Effect of time 2 and concentration on yield at temperature $=77^{\circ} \mathrm{C}$, time $1=30 \mathrm{~min}$.

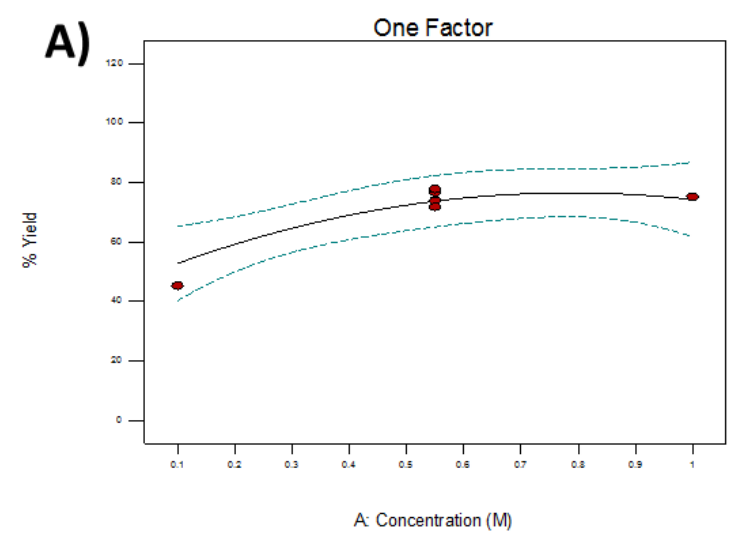

B)

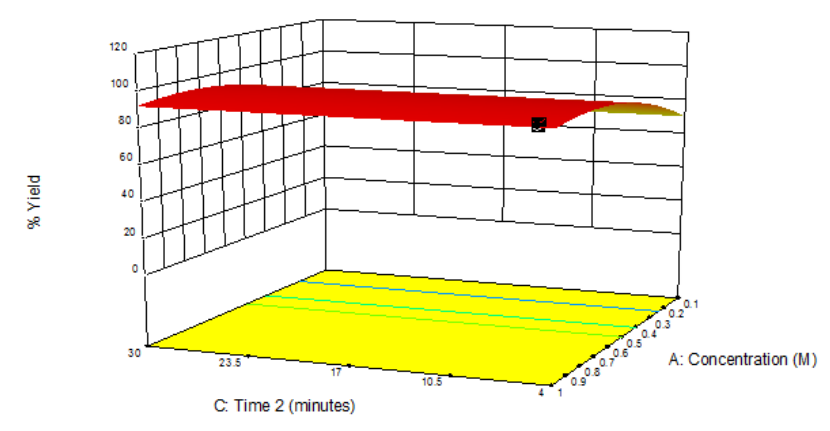




\section{Qualitative Light Stability Study}

Small samples of powdered iodonium salts were placed into scintillation vials and left adjacent to a window, exposed to ambient sunlight. A second sample of each salt was placed into a scintillation vial and wrapped with aluminum foil. The samples were periodically photographed. Any discoloration or change in consistency, appreciable upon visual inspection, was taken as evidence for decomposition. The photographs below are selected in order to illustrate the range of decomposition observed. See Figure S10 for a summary of results. Decomposition has not been observed when these compounds are stored in a freezer.

Figure S11. Study of ambient light stability of aryl(2,4,6-trimethoxyphenyl)iodonium salts.<smiles></smiles>

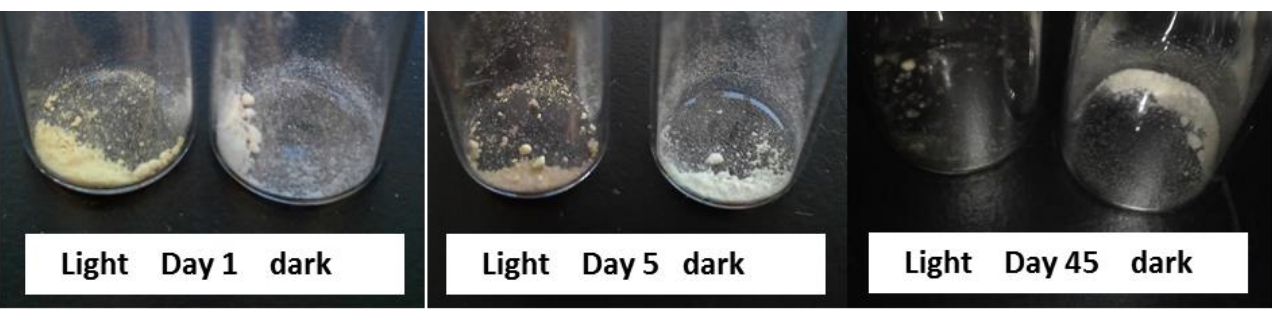<smiles></smiles>

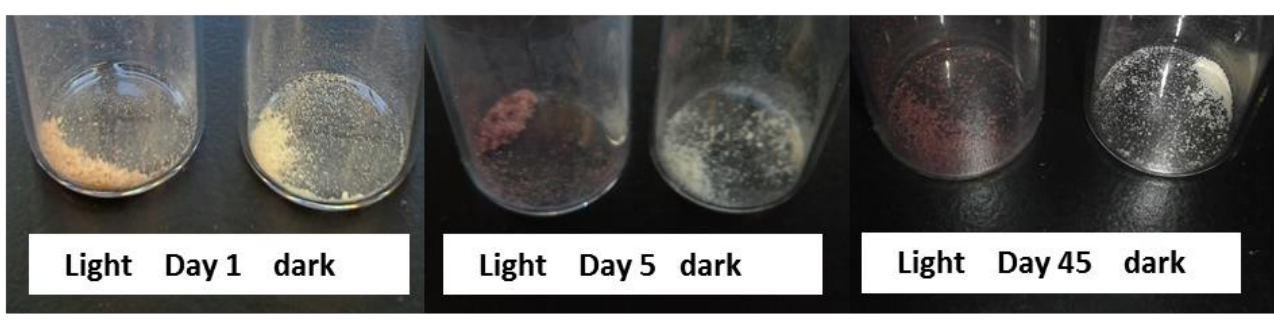<smiles>[13CH3]I([18OH])c1ccc(F)c(C(F)(F)F)c1</smiles>

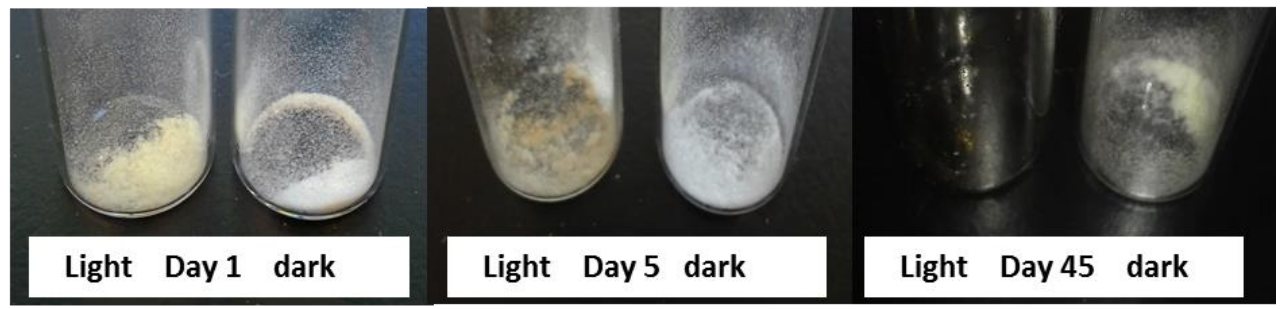<smiles></smiles>

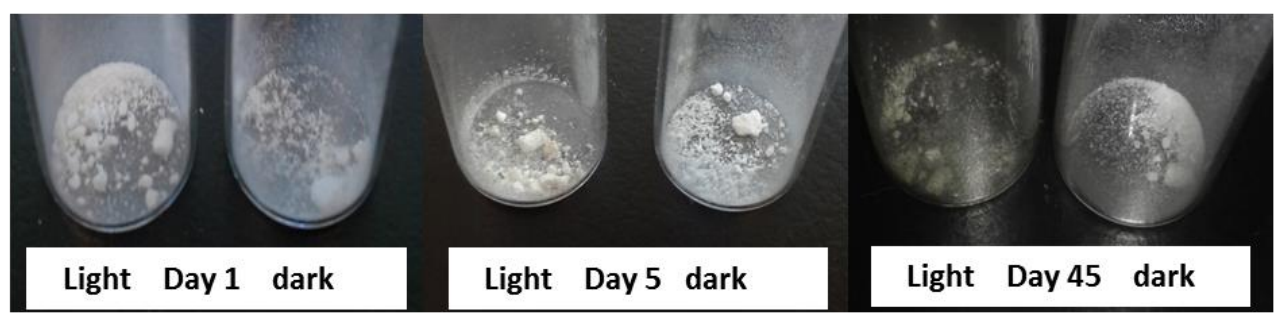




\section{Differential Scanning Calorimetry (DSC)}

Selected diaryliodonium salts were characterized by DSC in order to study thermal degradation behavior. Two aryl(TMB)iodonium salts were tested, one relatively more electron deficient and one more electron rich. Counter ions were varied for both.

Figure S10. Exotherm onset temperatures were measured by DSC for diaryl(TMB)iodonium salts with various counter anions.

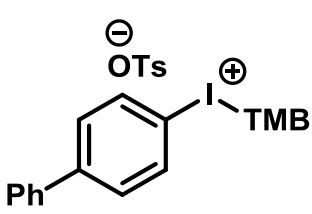

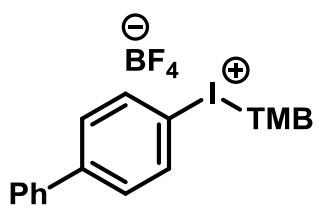<smiles></smiles>

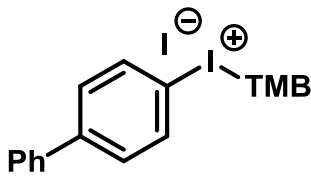

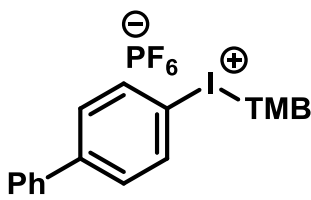<smiles>[13CH3][13C](=[18O])c1ccc(-c2ccccc2)cc1</smiles>

DSC exotherm

(deg C)

208

156

85

172

110<smiles>[13CH3]I([14CH3])c1ccc(F)c(C(F)(F)F)c1</smiles>

\section{DSC exotherm}

(deg C)<smiles></smiles>

224 


\section{Reaction Temperature Profiles}

Figure S8. In-situ temperature measurement of a $20 \mathrm{mmol}$ synthesis of compound $\mathbf{4}$ conducted at room temperature.

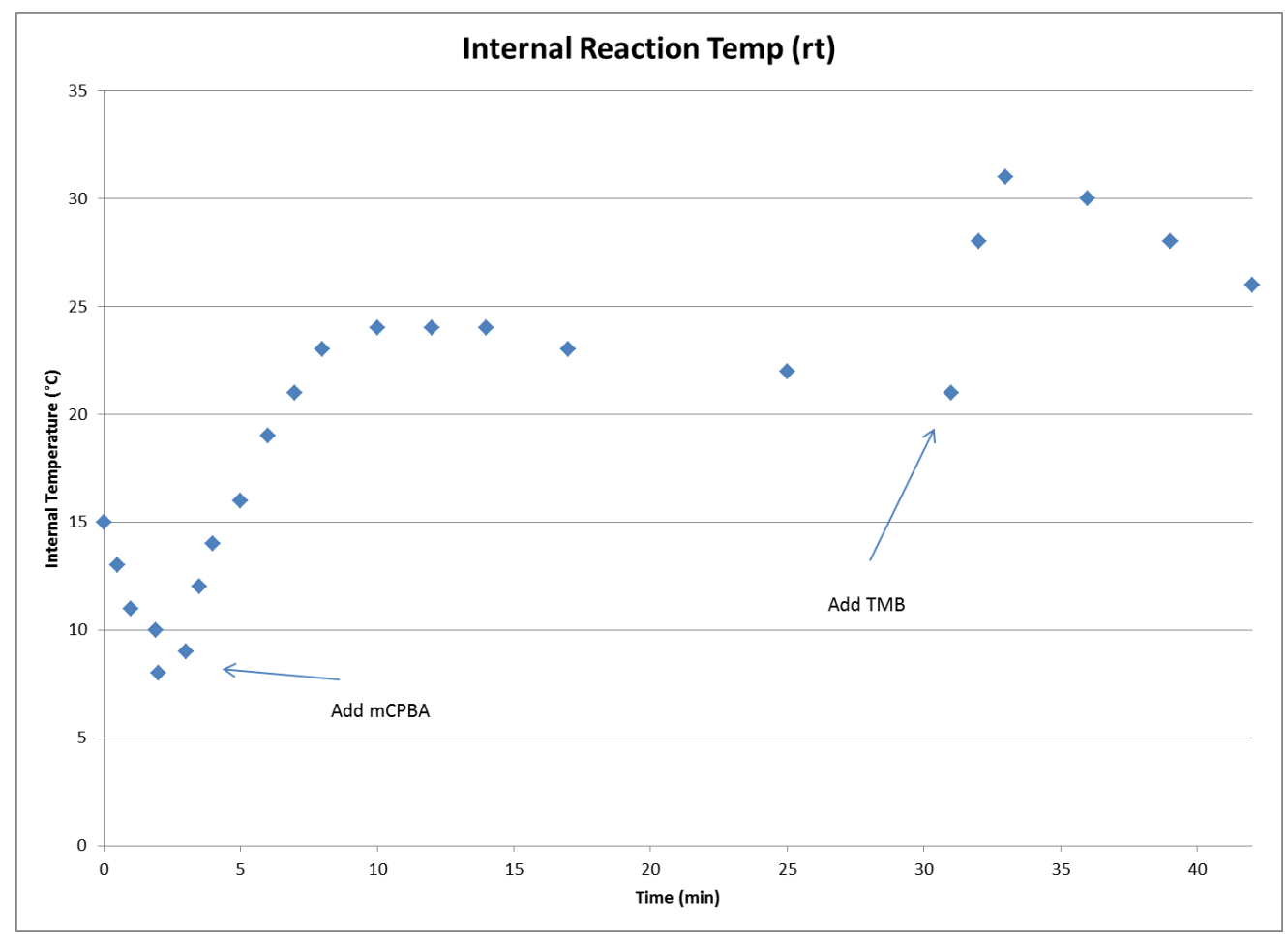

Figure S9. In-situ temperature measurement of a $20 \mathrm{mmol}$ synthesis of compound 2 conducted at $77{ }^{\circ} \mathrm{C}$.

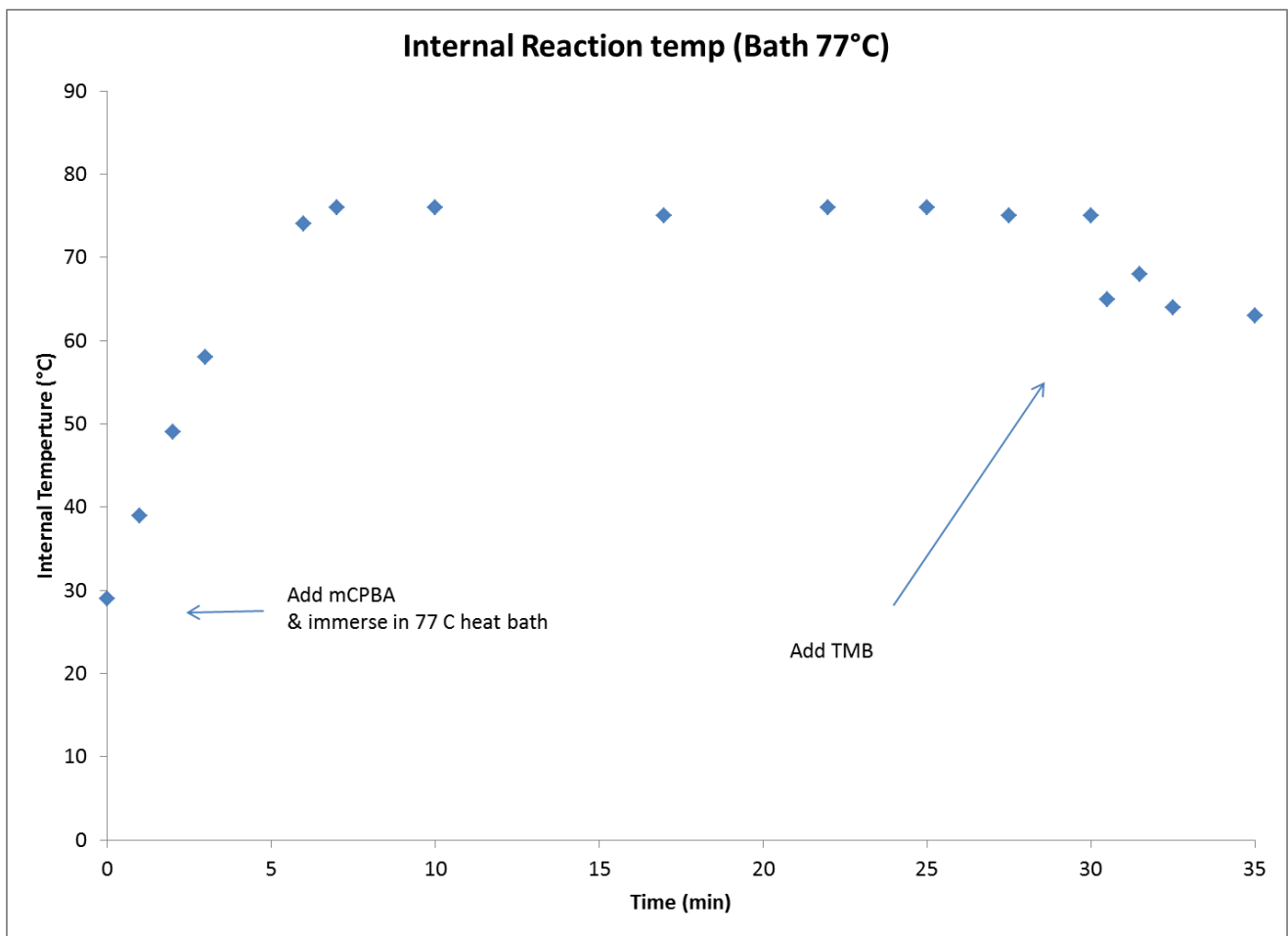


5. ${ }^{1} \mathrm{H},{ }^{13} \mathrm{C},{ }^{19} \mathrm{~F}$ NMR spectra of new compounds

- ${ }^{1} \mathrm{H}$ NMR spectrum of 2 at $400 \mathrm{MHz}$ in DMSO- $d_{6}$ at $298 \mathrm{~K}$

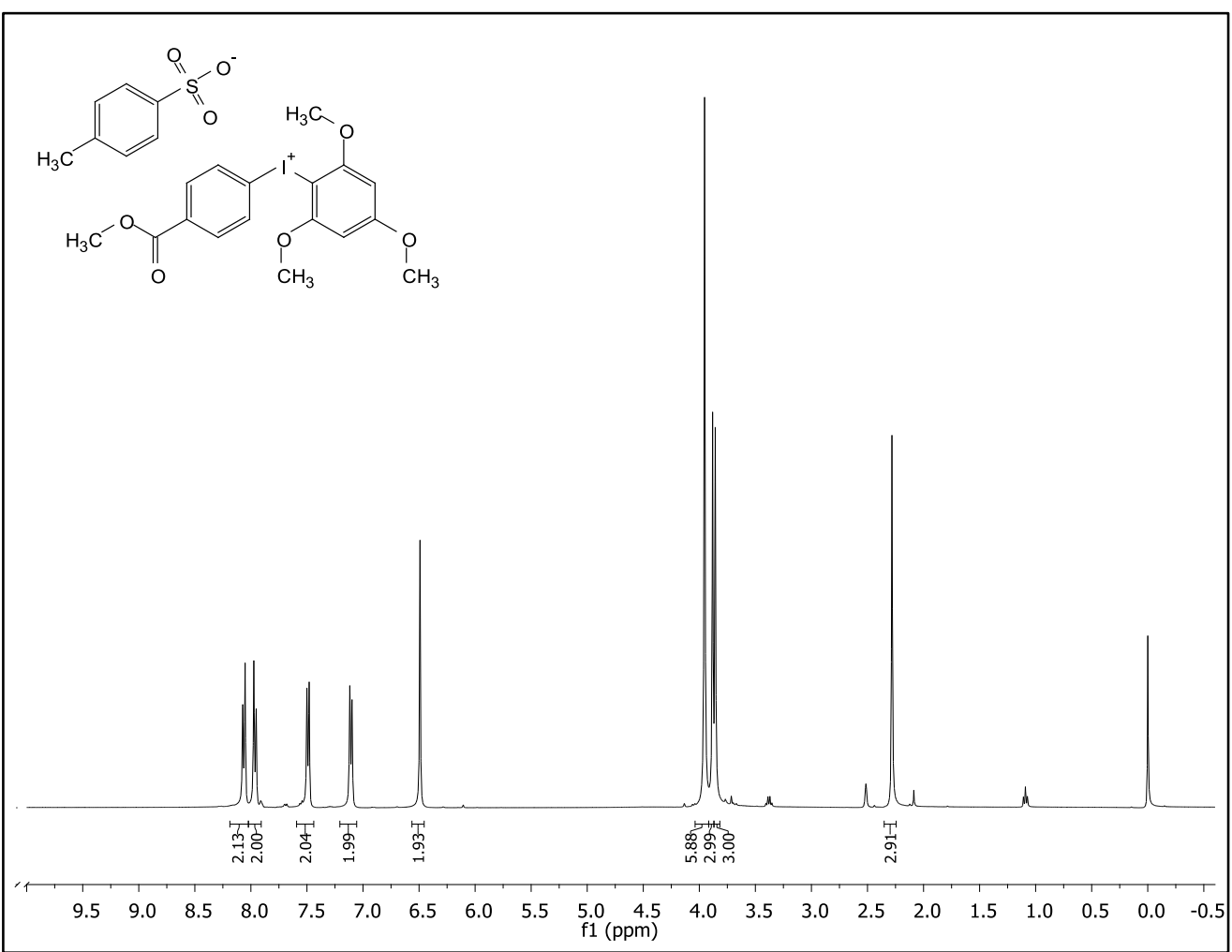

- ${ }^{13} \mathrm{C}$ NMR spectrum of 2 at $101 \mathrm{MHz}$ in DMSO- $d_{6}$ at $298 \mathrm{~K}$

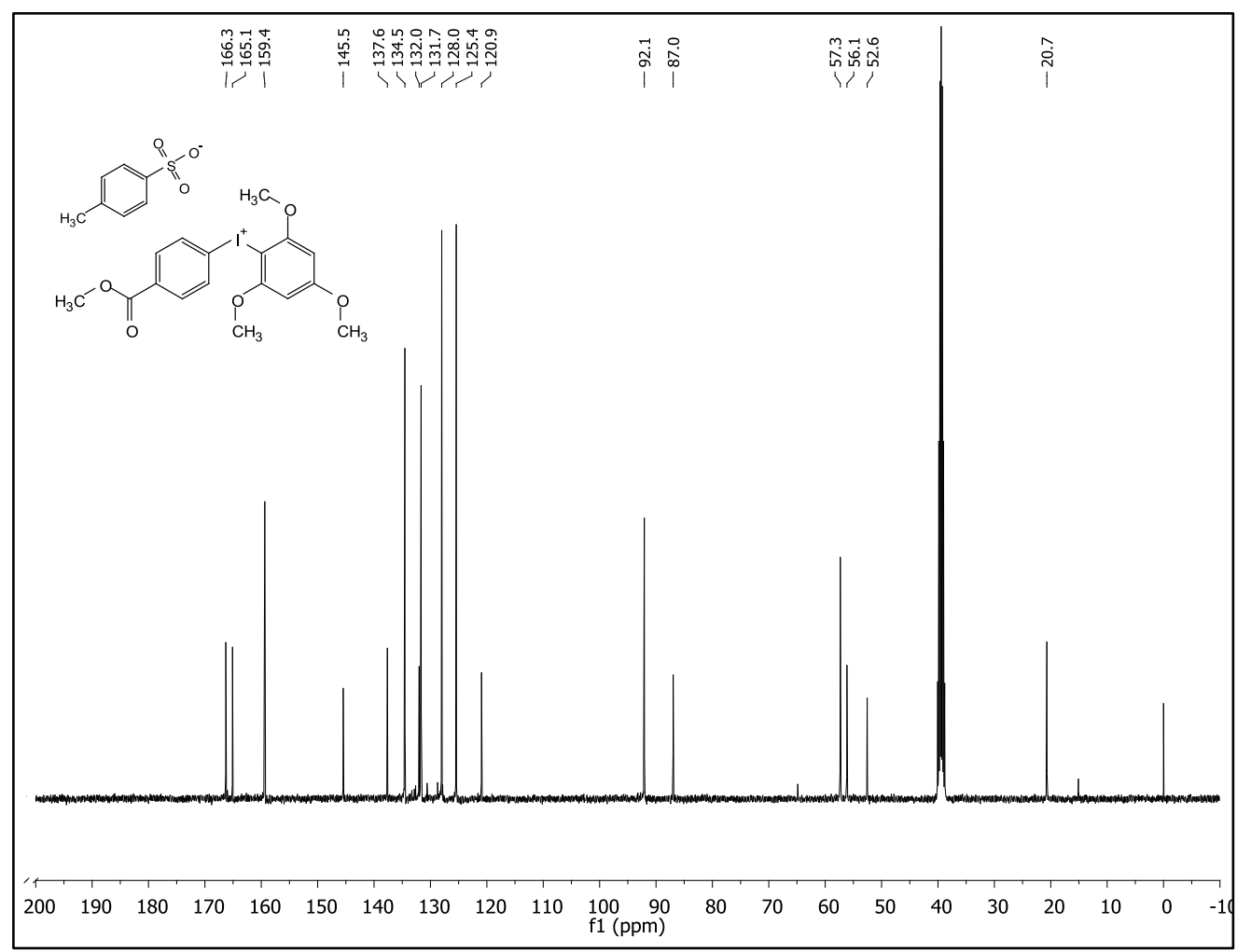


- ${ }^{1} \mathrm{H}$ NMR spectrum of 3 at $400 \mathrm{MHz}$ in DMSO- $d_{6}$ at $298 \mathrm{~K}$

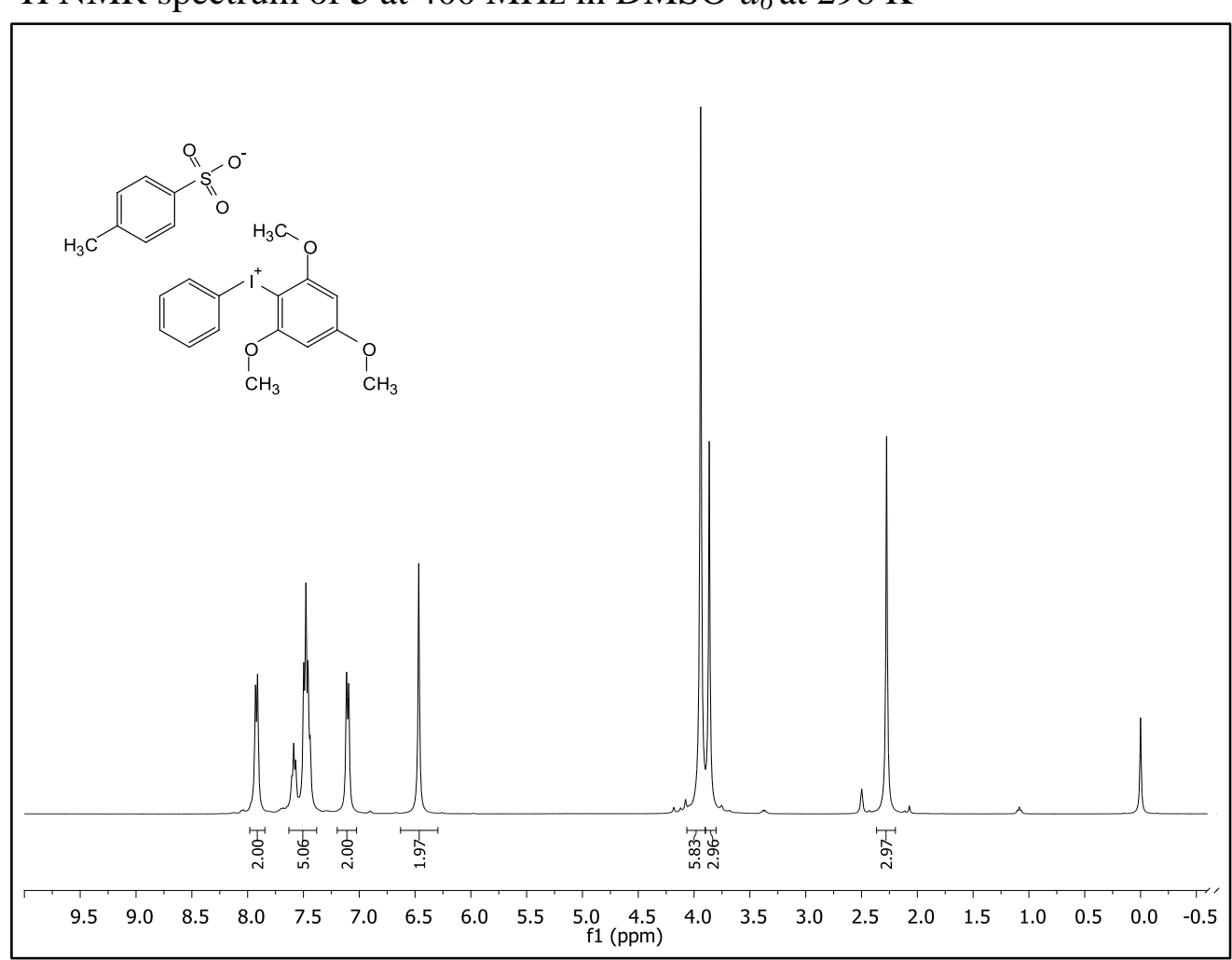

- ${ }^{13} \mathrm{C}$ NMR spectrum of $\mathbf{3}$ at $101 \mathrm{MHz}$ in DMSO- $d_{6}$ at $298 \mathrm{~K}$

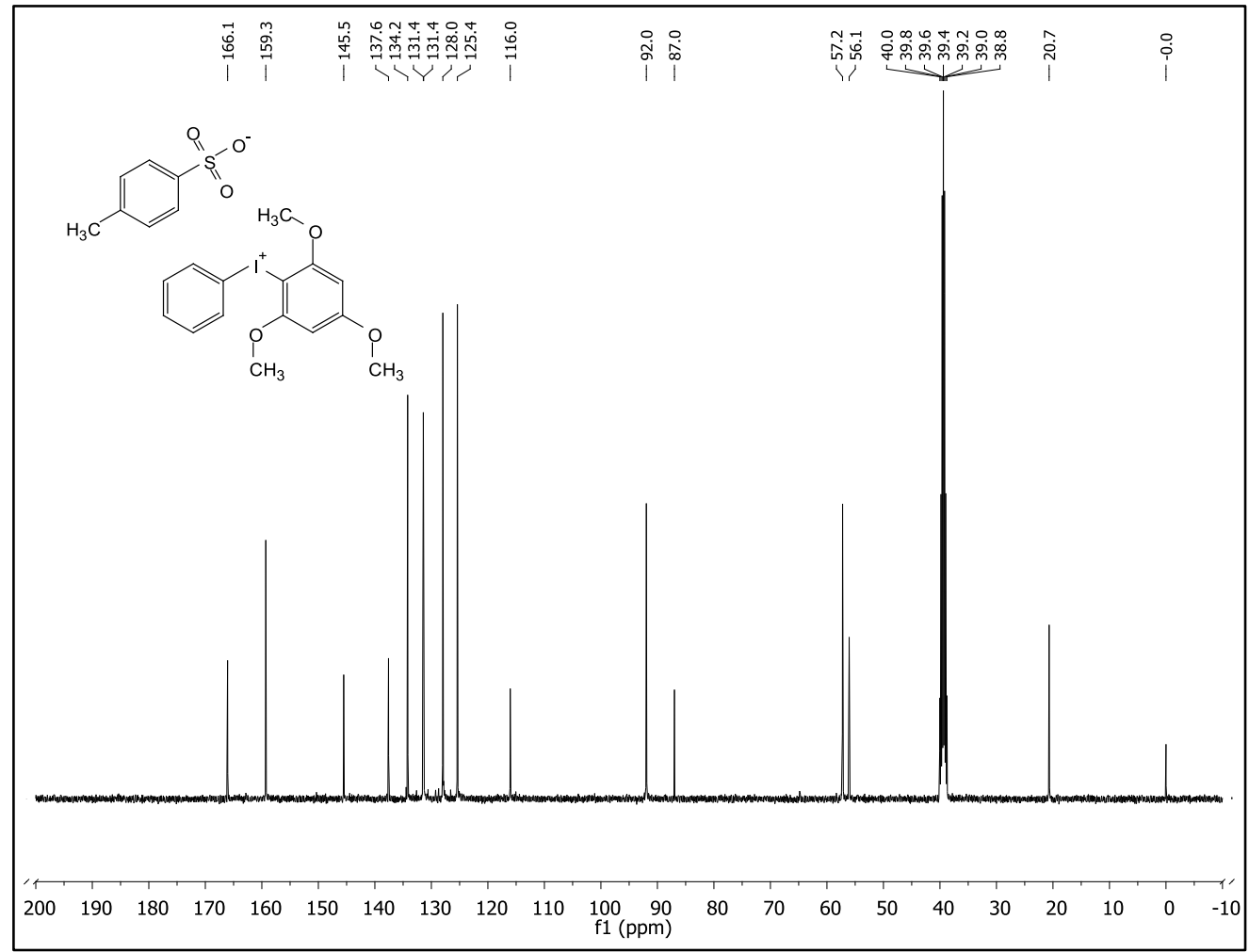


- ${ }^{1} \mathrm{H}$ NMR spectrum of $\mathbf{4}$ at $400 \mathrm{MHz}$ in DMSO- $d_{6}$ at $298 \mathrm{~K}$
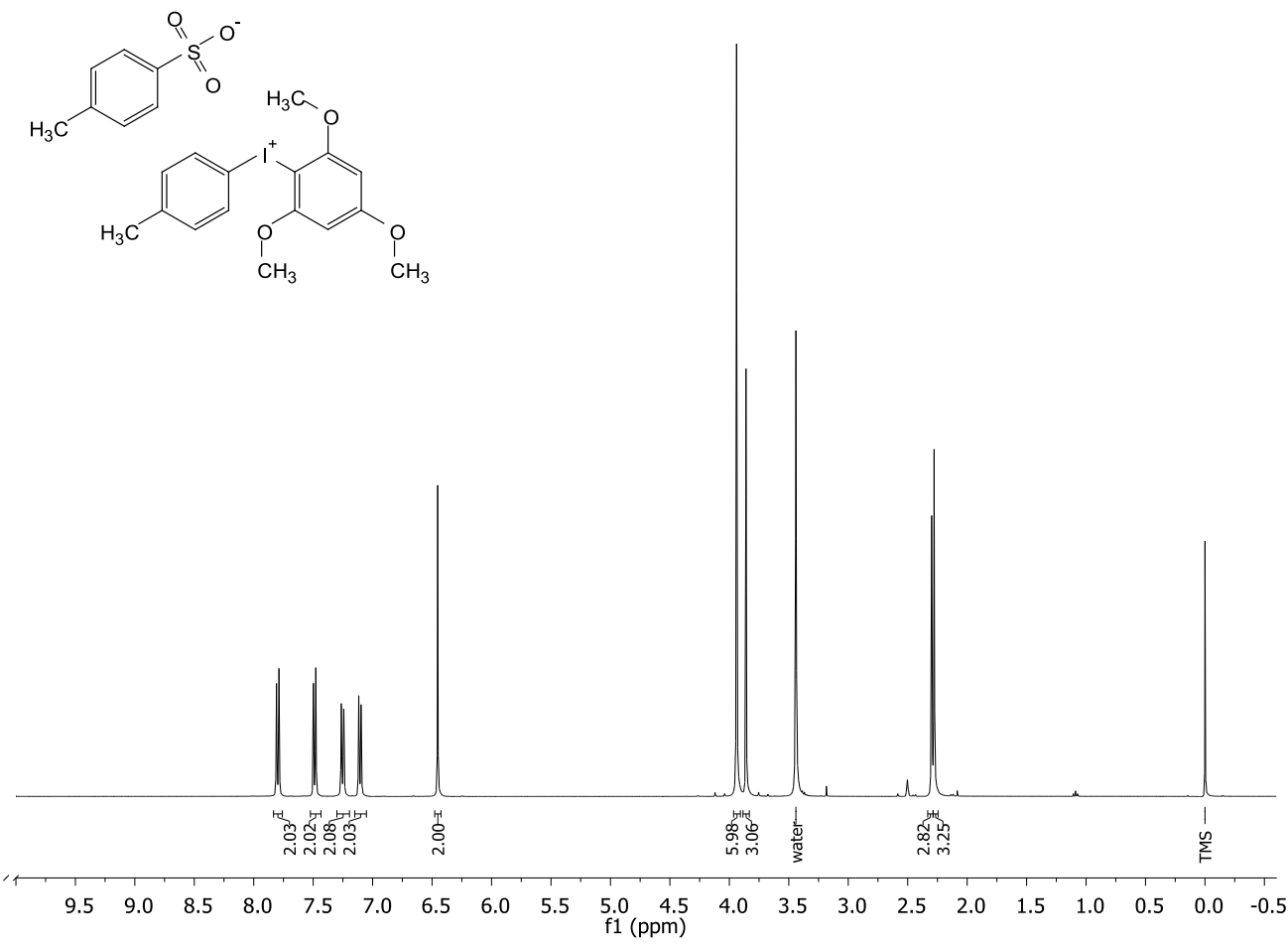

- ${ }^{13} \mathrm{C}$ NMR spectrum of 4 at $101 \mathrm{MHz}$ in DMSO- $d_{6}$ at $298 \mathrm{~K}$

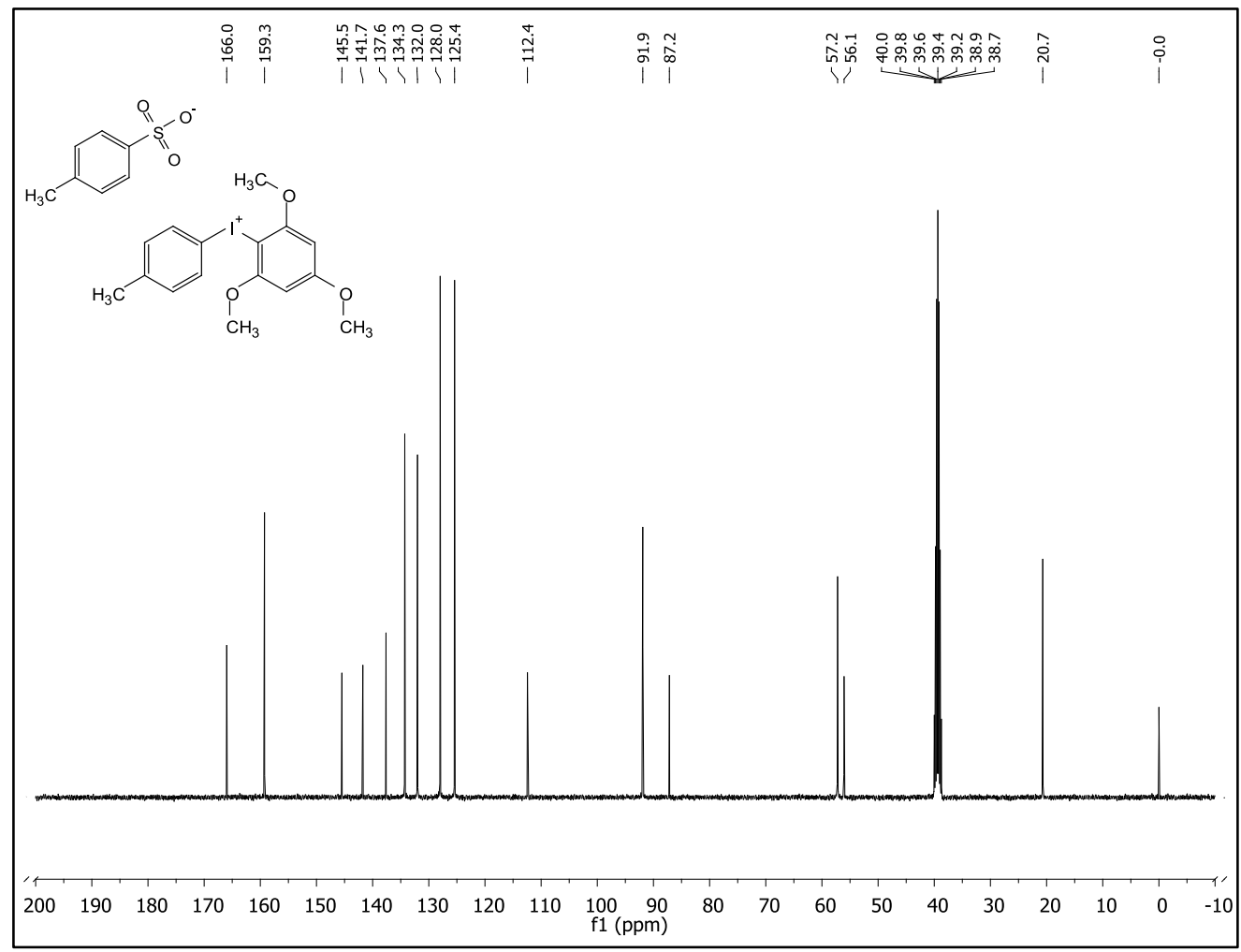


- ${ }^{1} \mathrm{H}$ NMR spectrum of 5 at $400 \mathrm{MHz}$ in DMSO- $d_{6}$ at $298 \mathrm{~K}$
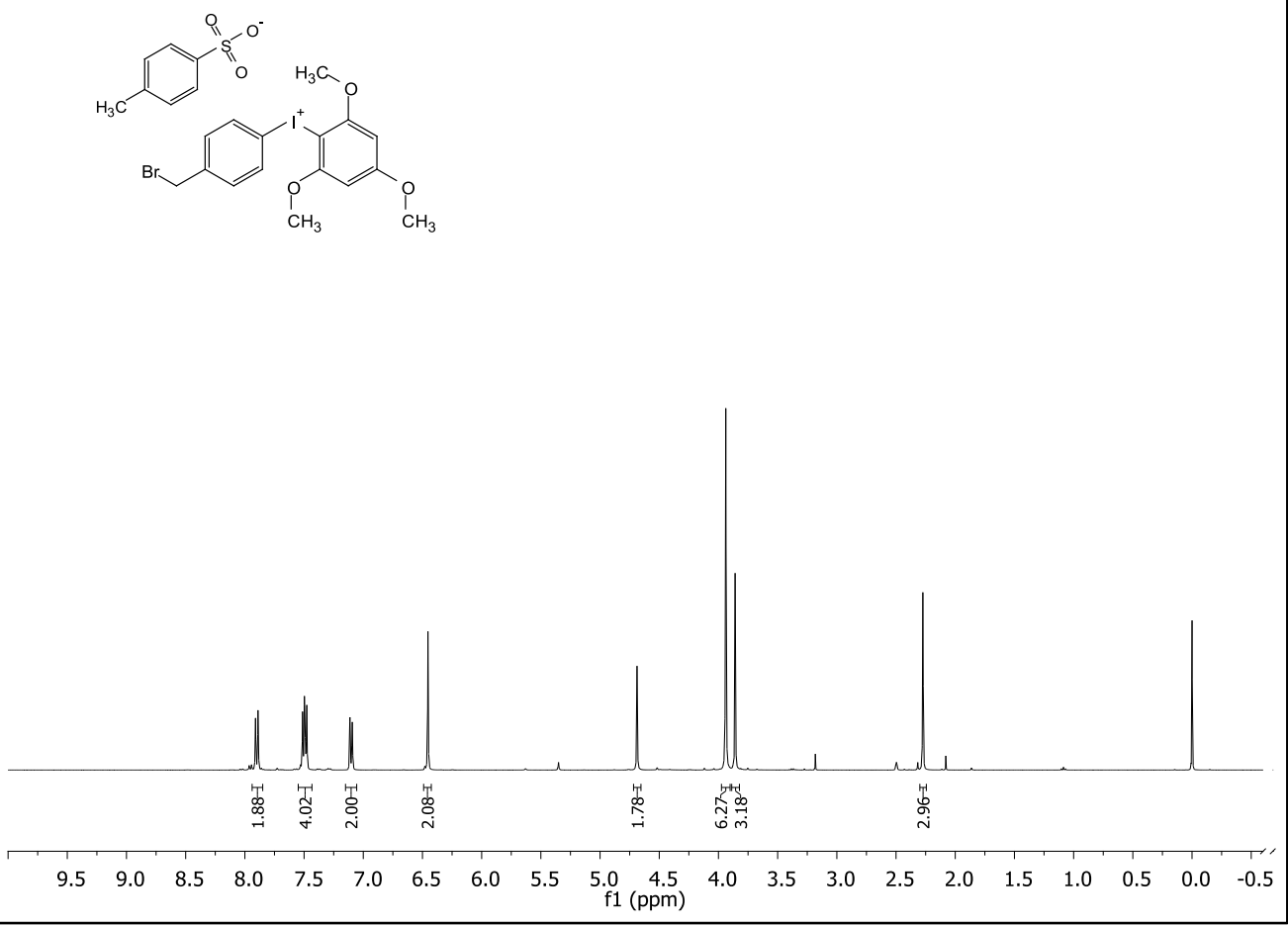

- ${ }^{13} \mathrm{C}$ NMR spectrum of 5 at $101 \mathrm{MHz}$ in DMSO- $d_{6}$ at $298 \mathrm{~K}$

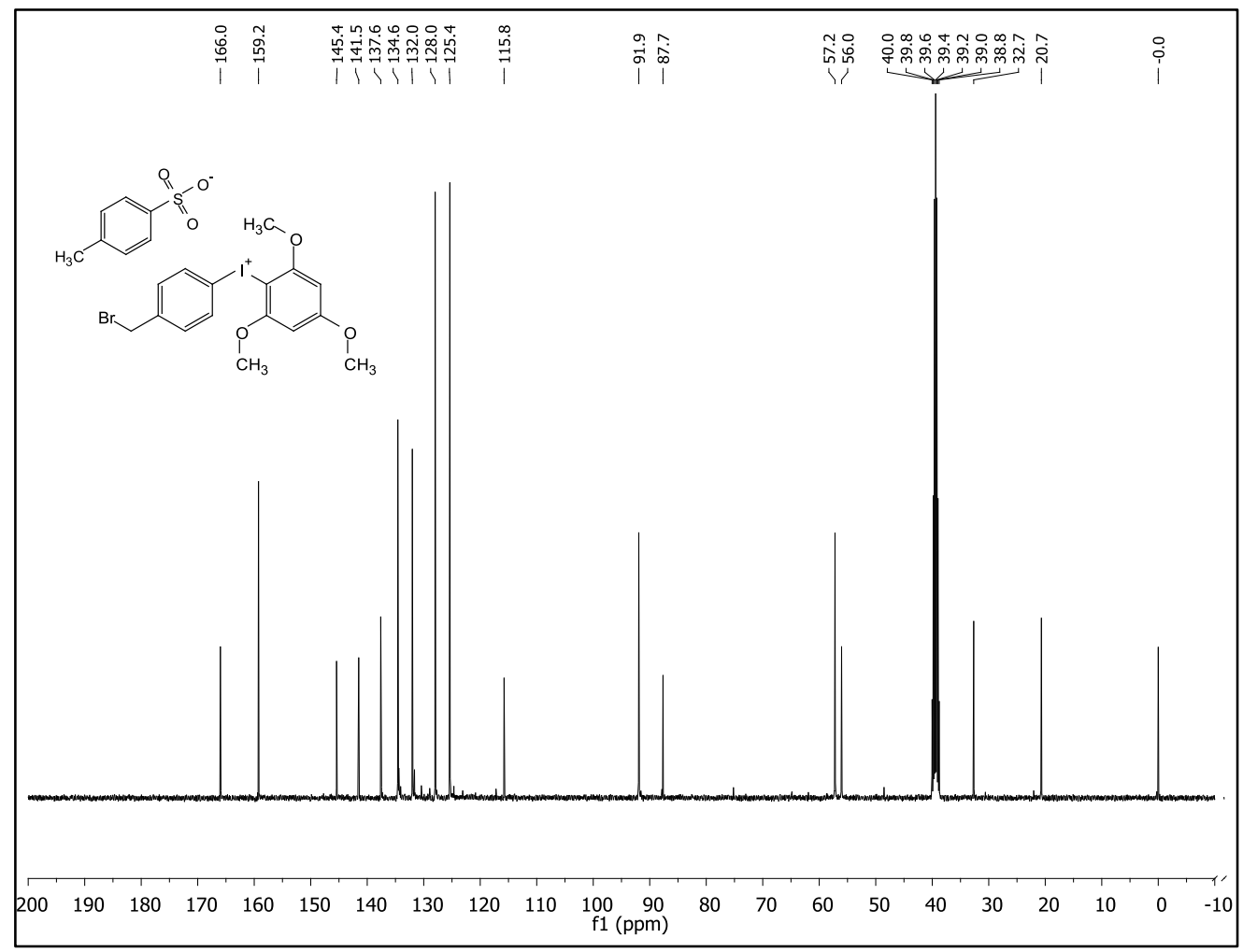


- ${ }^{1} \mathrm{H}$ NMR spectrum of 6 at $400 \mathrm{MHz}$ in DMSO- $d_{6}$ at $298 \mathrm{~K}$
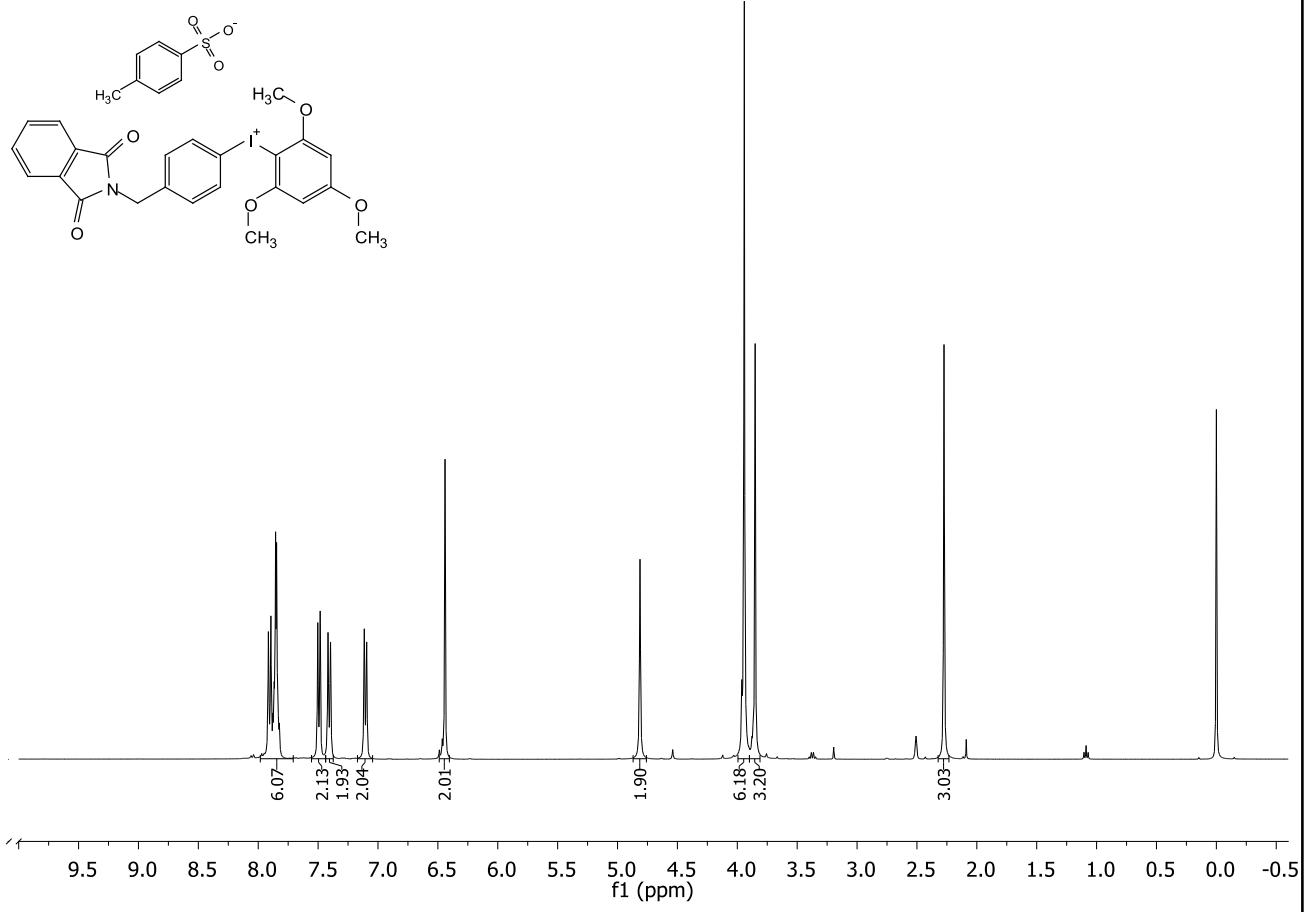

- ${ }^{13} \mathrm{C}$ NMR spectrum of 6 at $101 \mathrm{MHz}$ in DMSO- $d_{6}$ at $298 \mathrm{~K}$

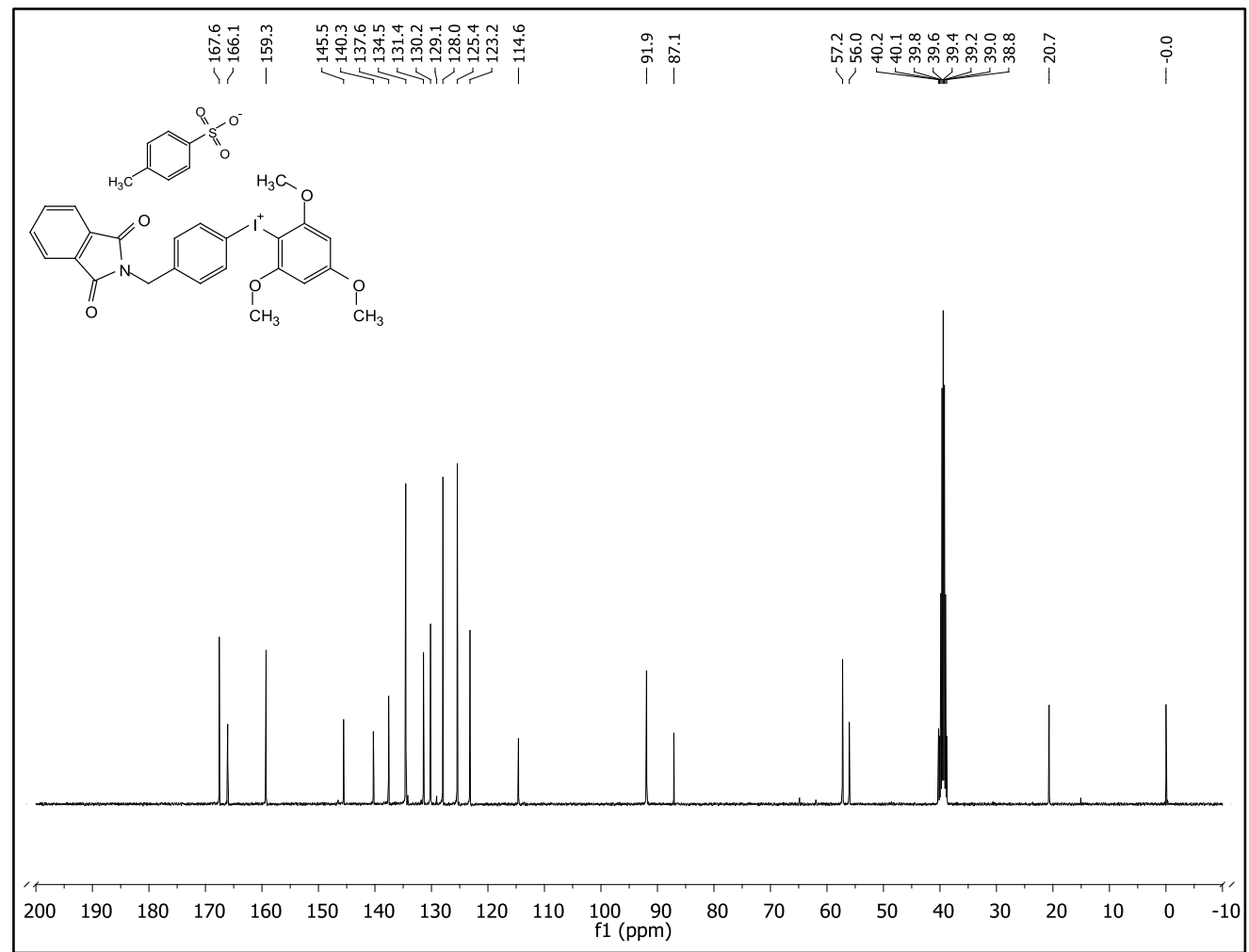


- ${ }^{1} \mathrm{H}$ NMR spectrum of 7 at $400 \mathrm{MHz}$ in DMSO- $d_{6}$ at $298 \mathrm{~K}$
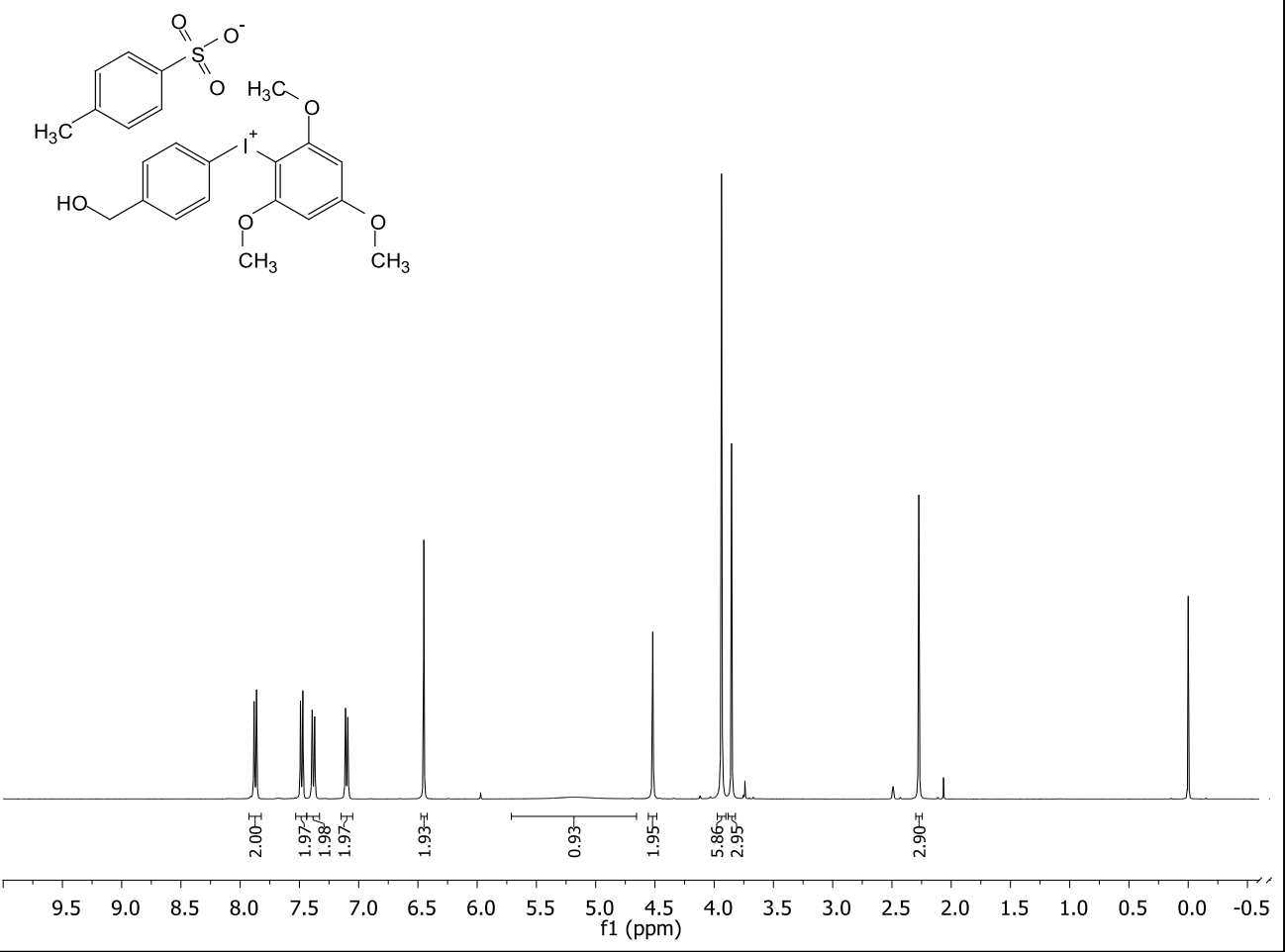

- ${ }^{13} \mathrm{C}$ NMR spectrum of 7 at $101 \mathrm{MHz}$ in DMSO- $d_{6}$ at $298 \mathrm{~K}$

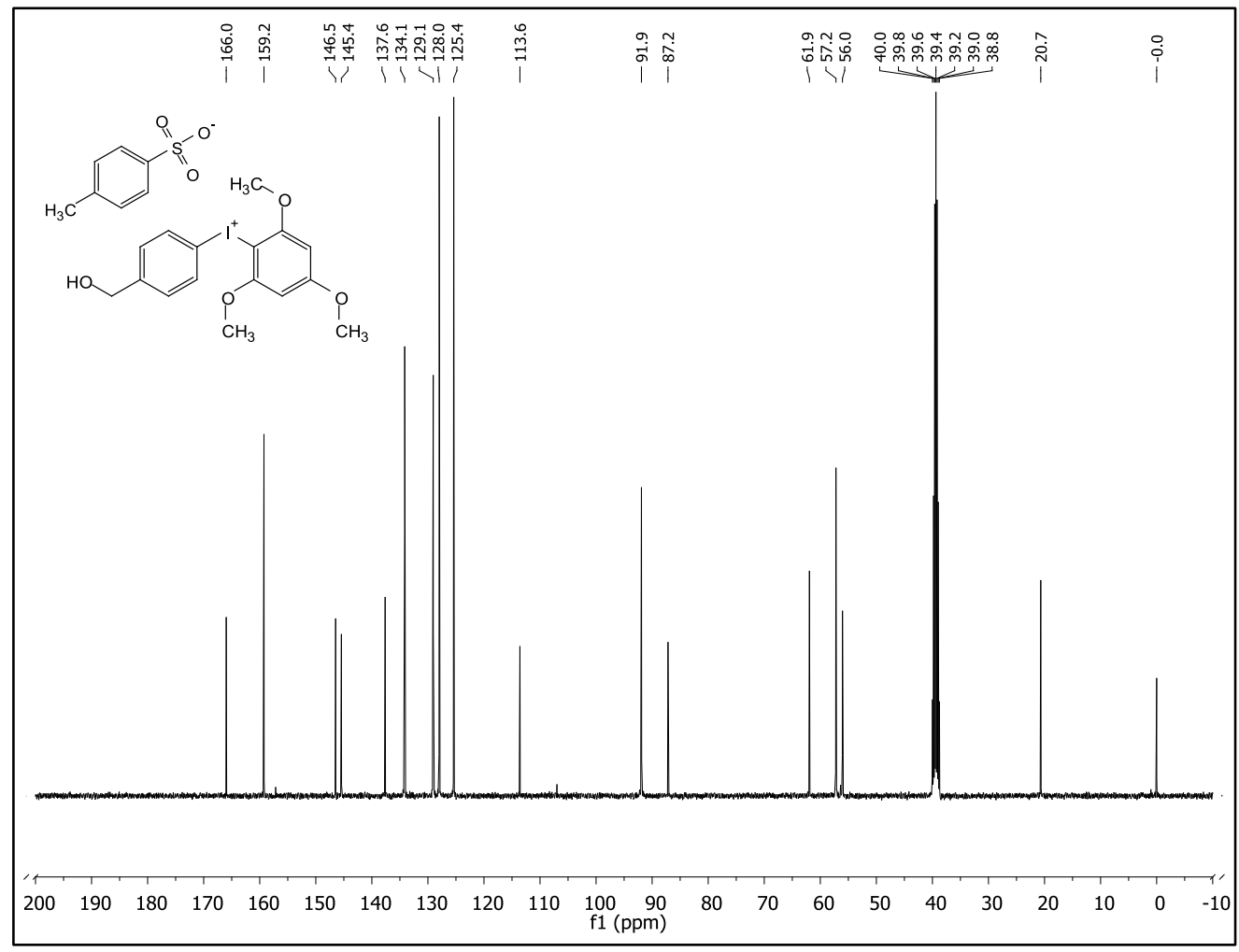


- ${ }^{1} \mathrm{H}$ NMR spectrum of 8 at $400 \mathrm{MHz}$ in DMSO- $d_{6}$ at $298 \mathrm{~K}$

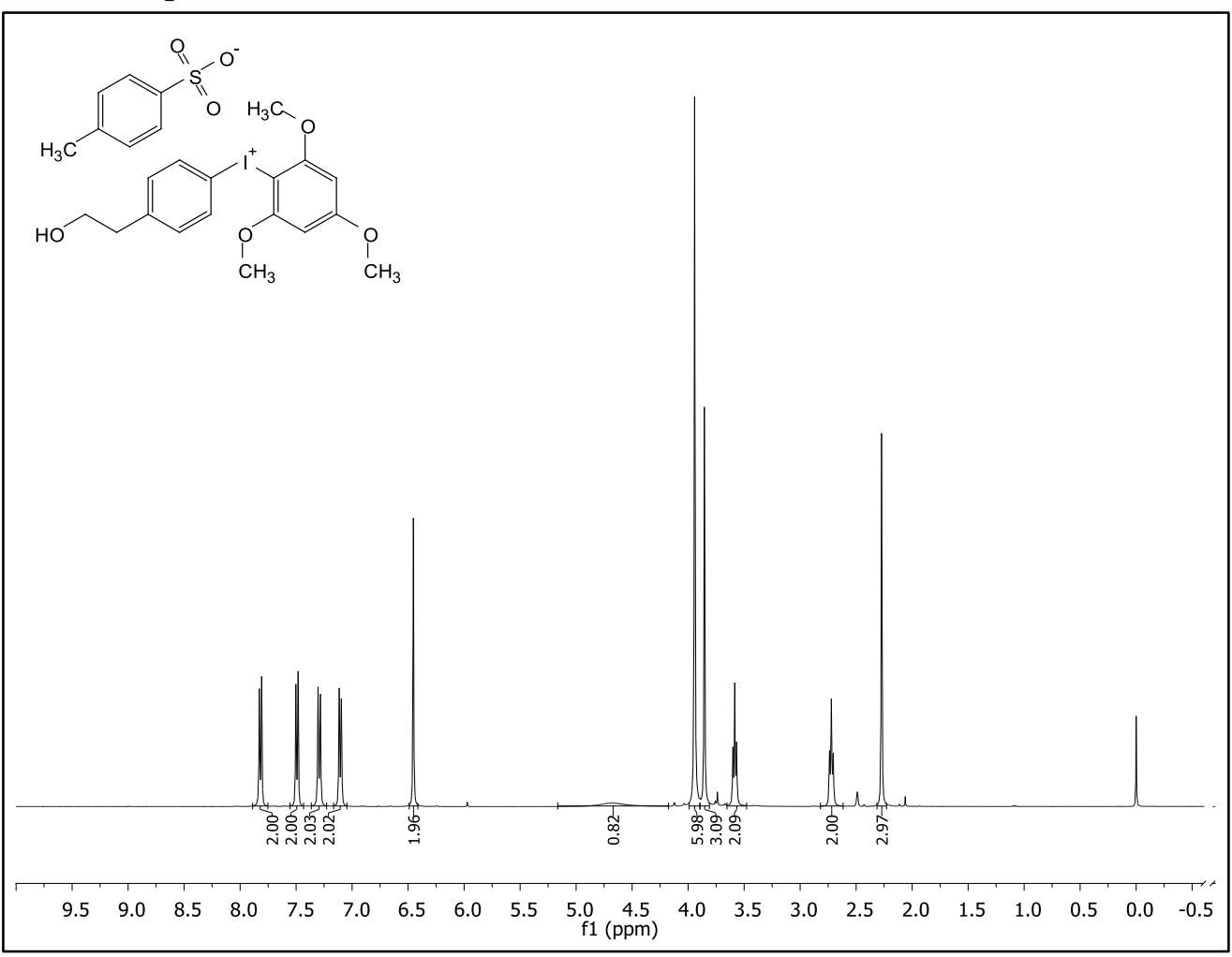

- ${ }^{13} \mathrm{C}$ NMR spectrum of 8 at $101 \mathrm{MHz}$ in DMSO- $d_{6}$ at $298 \mathrm{~K}$

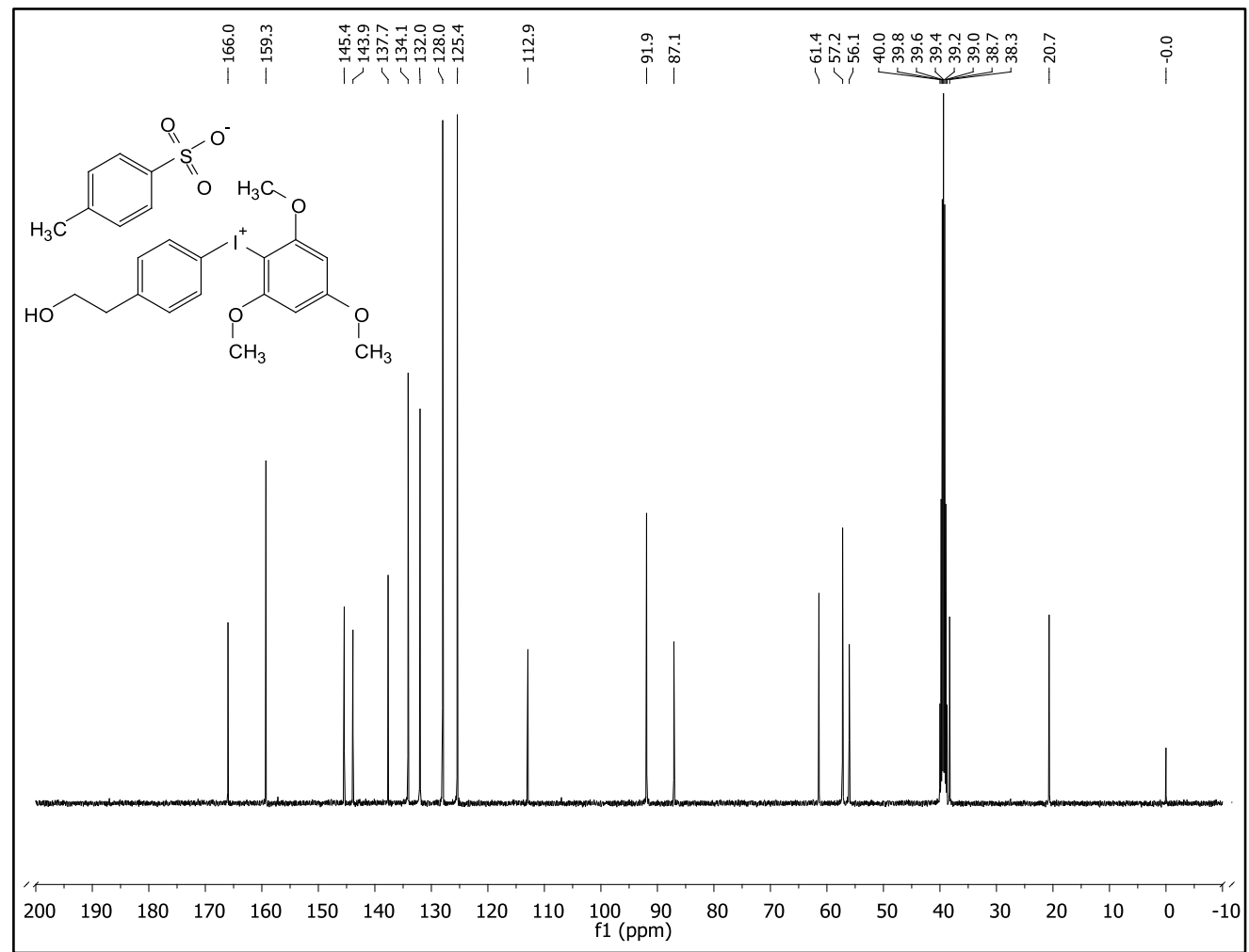


- ${ }^{1} \mathrm{H}$ NMR spectrum of 9 at $400 \mathrm{MHz}$ in DMSO- $d_{6}$ at $298 \mathrm{~K}$

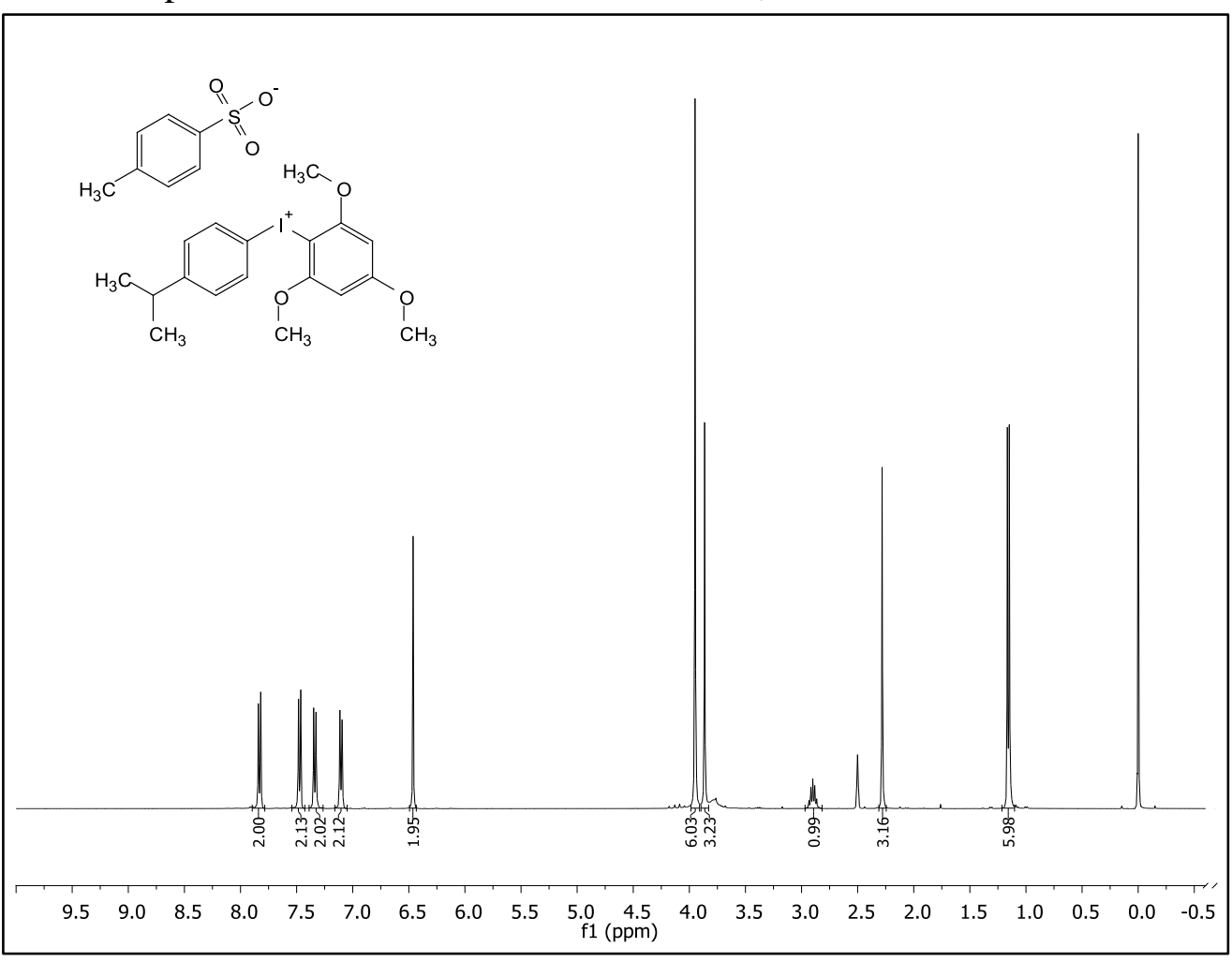

- ${ }^{13} \mathrm{C}$ NMR spectrum of 9 at $101 \mathrm{MHz}$ in DMSO- $d_{6}$ at $298 \mathrm{~K}$

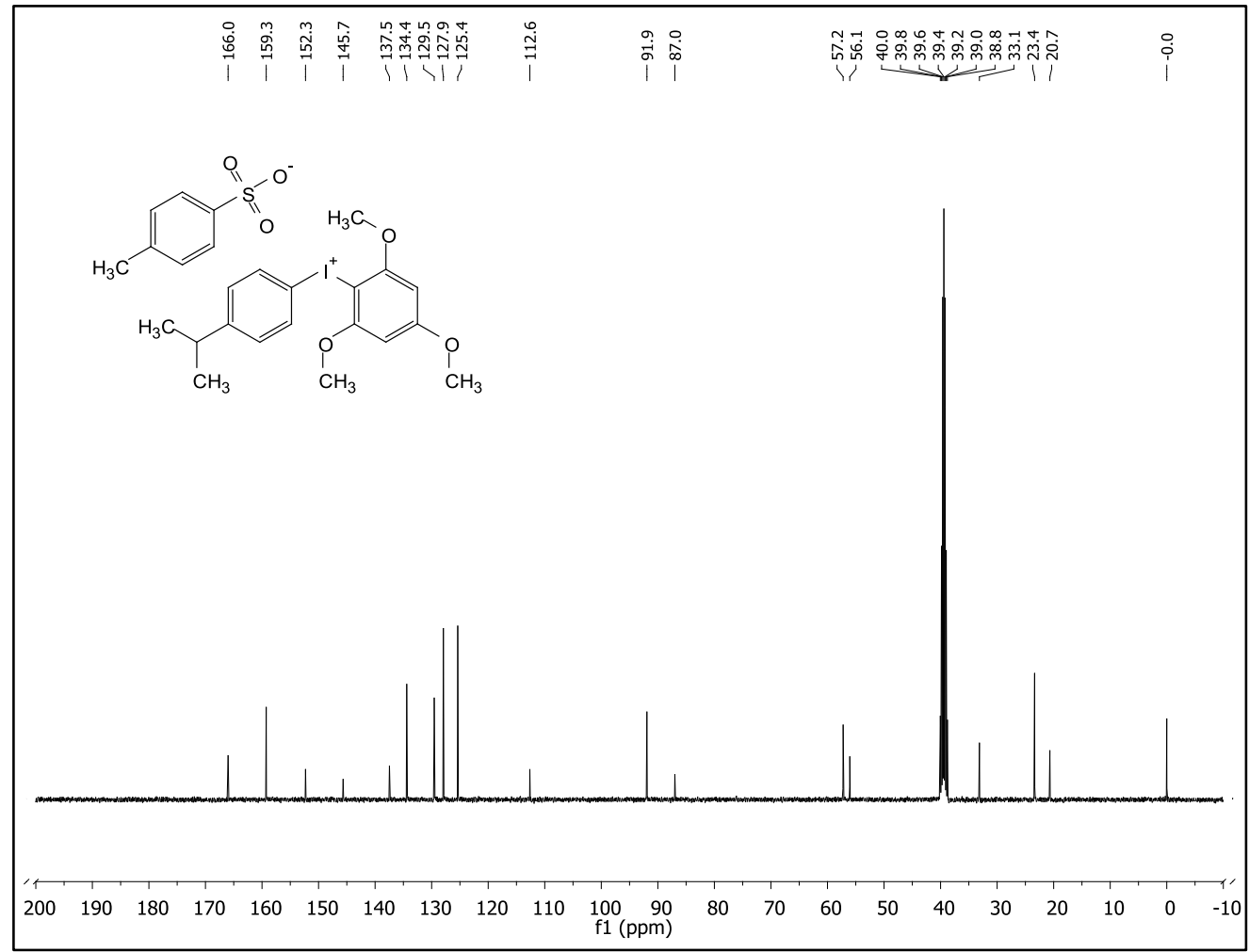


S20

- $\quad{ }^{1} \mathrm{H}$ NMR spectrum of $\mathbf{1 0}$ at $400 \mathrm{MHz}$ in DMSO- $d_{6}$ at $298 \mathrm{~K}$

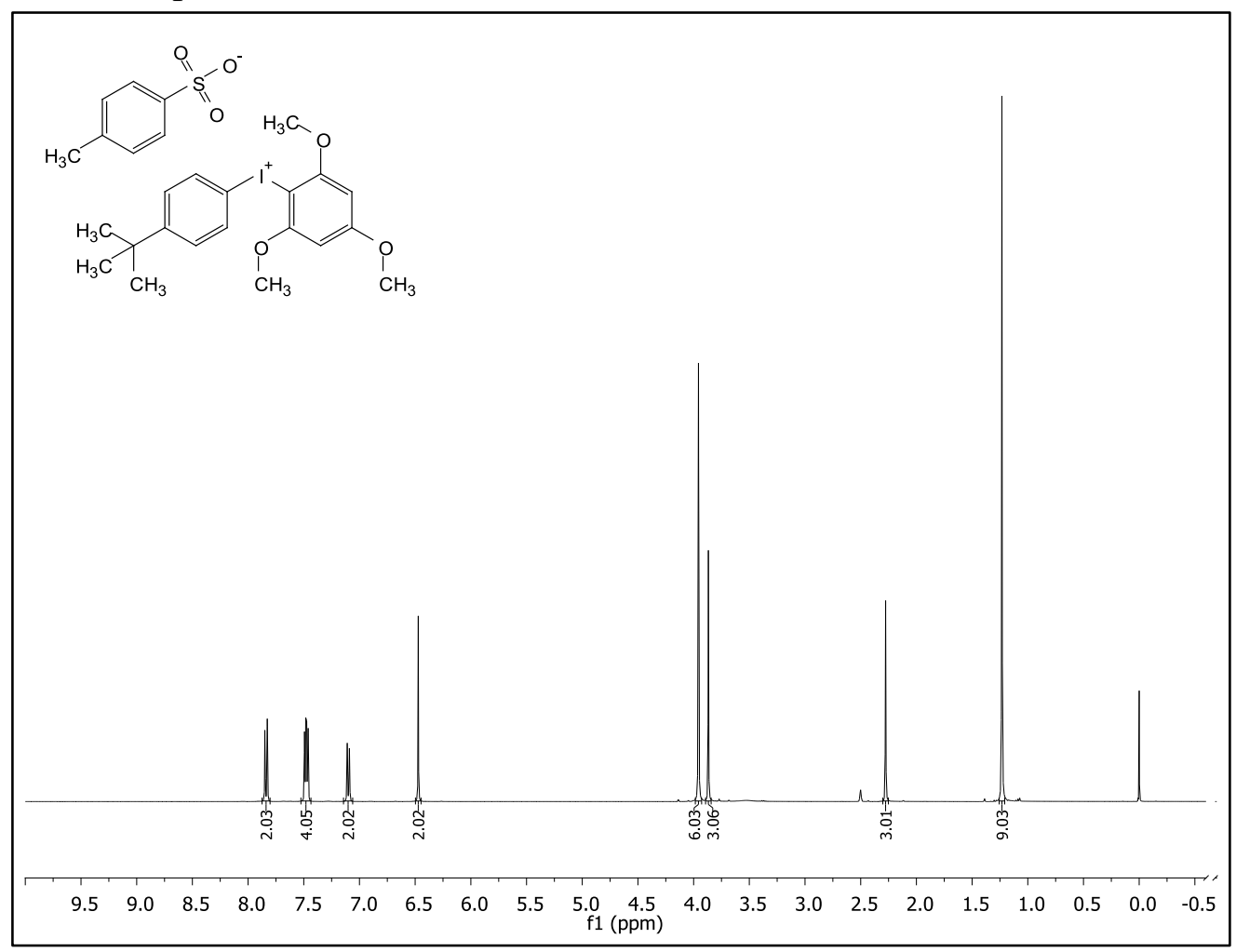

- ${ }^{13} \mathrm{C}$ NMR spectrum of $\mathbf{1 0}$ at $101 \mathrm{MHz}$ in DMSO- $d_{6}$ at $298 \mathrm{~K}$

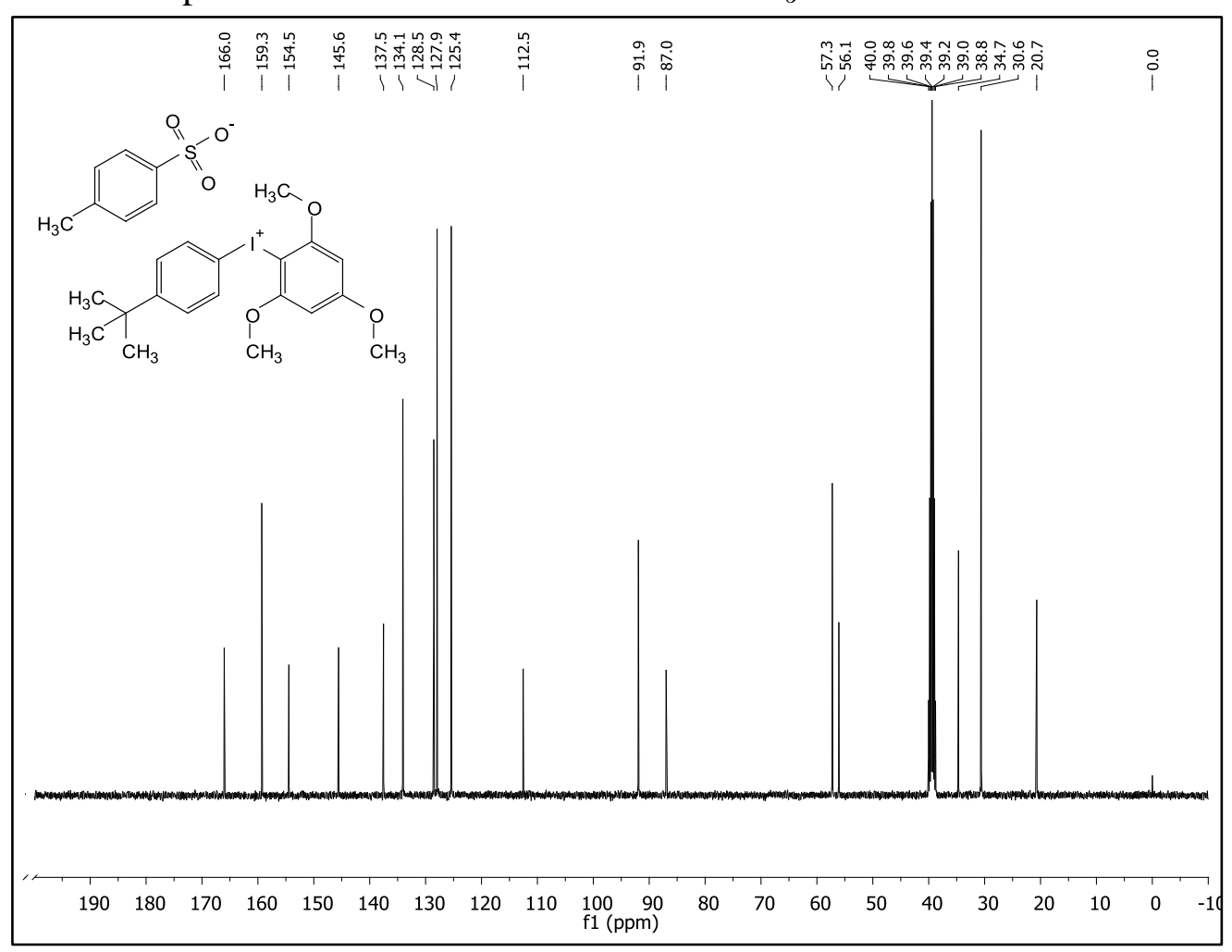


- ${ }^{1} \mathrm{H}$ NMR spectrum of $\mathbf{1 1}$ at $400 \mathrm{MHz}$ in DMSO- $d_{6}$ at $298 \mathrm{~K}$

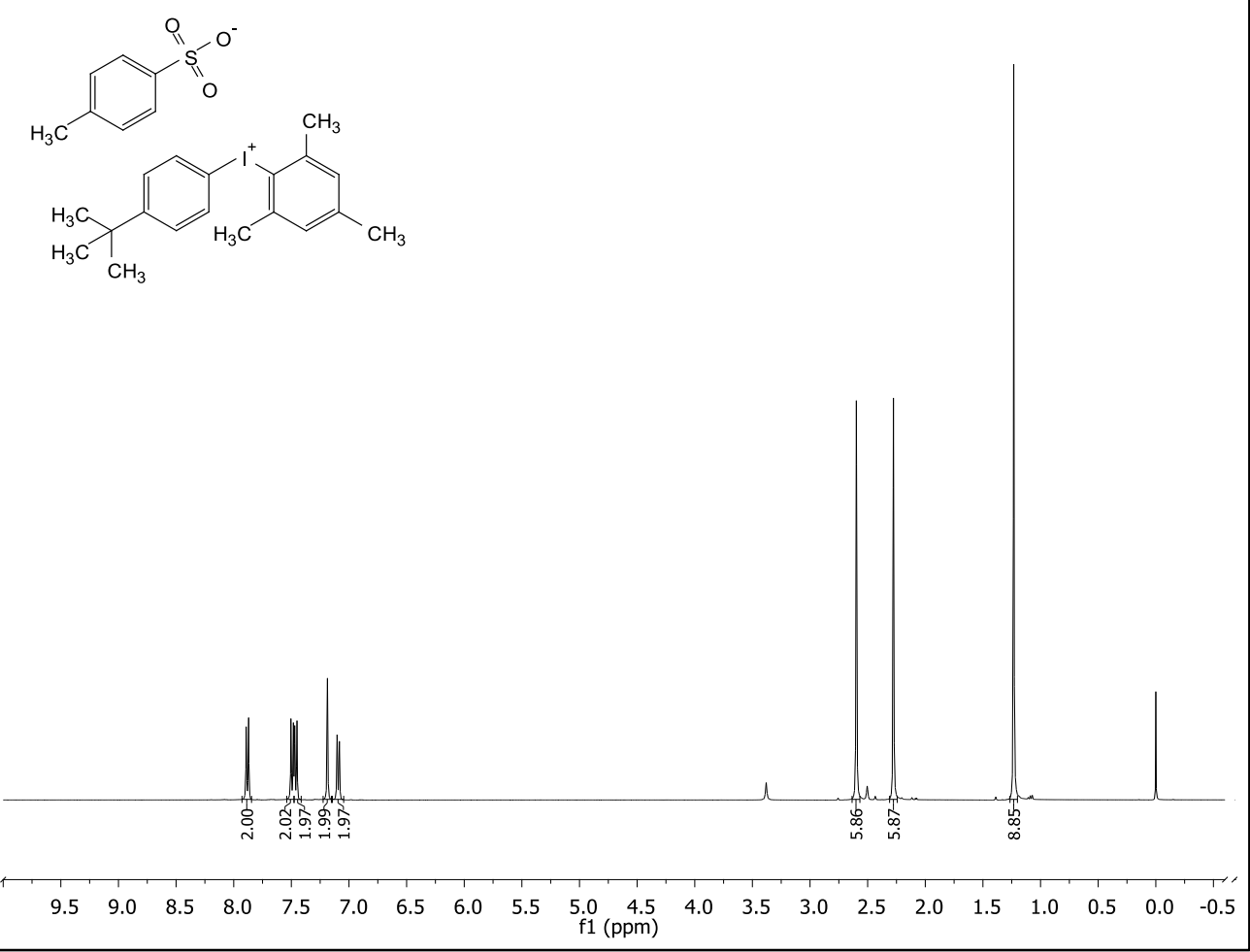

- ${ }^{13} \mathrm{C}$ NMR spectrum of $\mathbf{1 1}$ at $101 \mathrm{MHz}$ in DMSO- $d_{6}$ at $298 \mathrm{~K}$

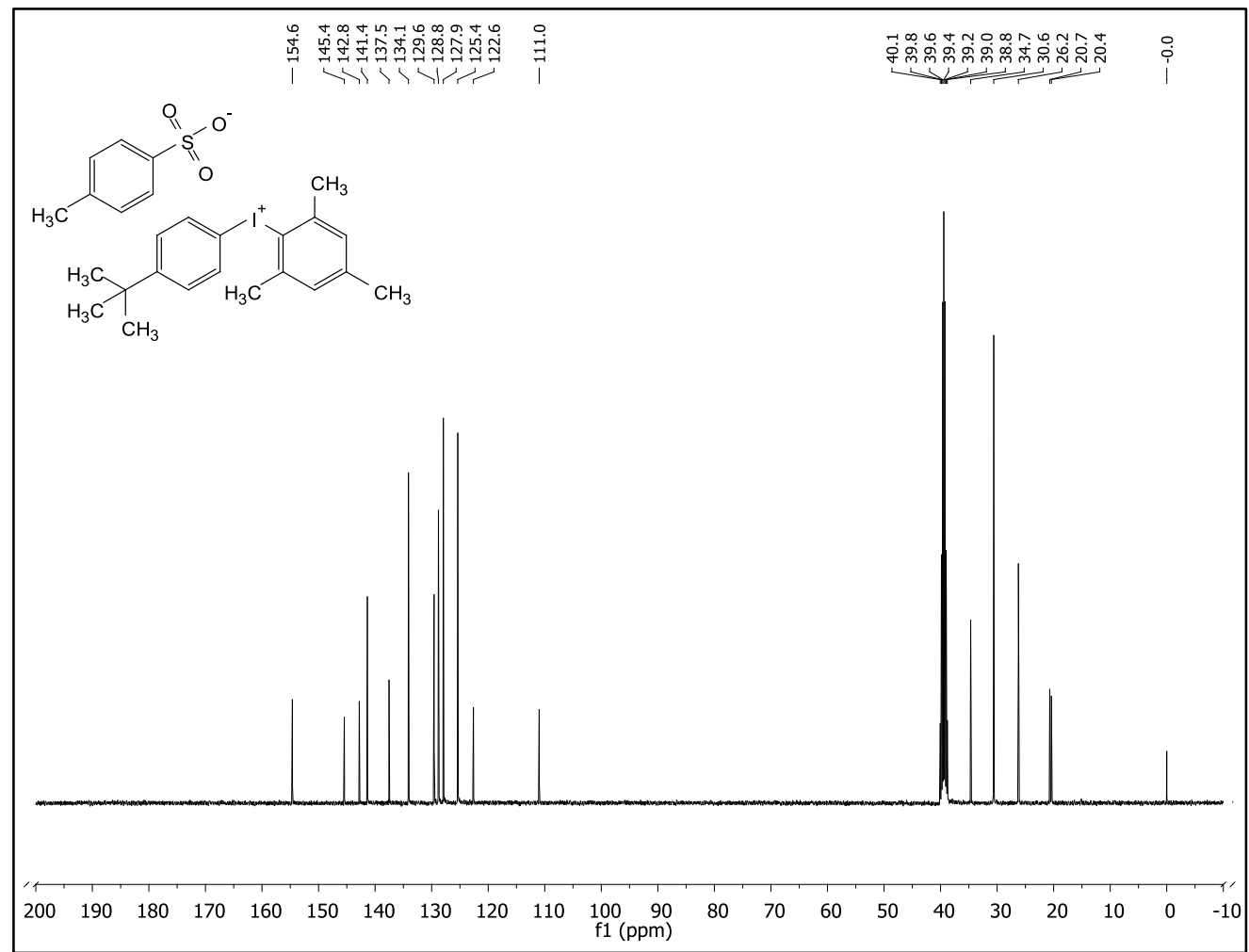


- ${ }^{1} \mathrm{H}$ NMR spectrum of $\mathbf{1 2}$ at $400 \mathrm{MHz}$ in DMSO- $d_{6}$ at $298 \mathrm{~K}$

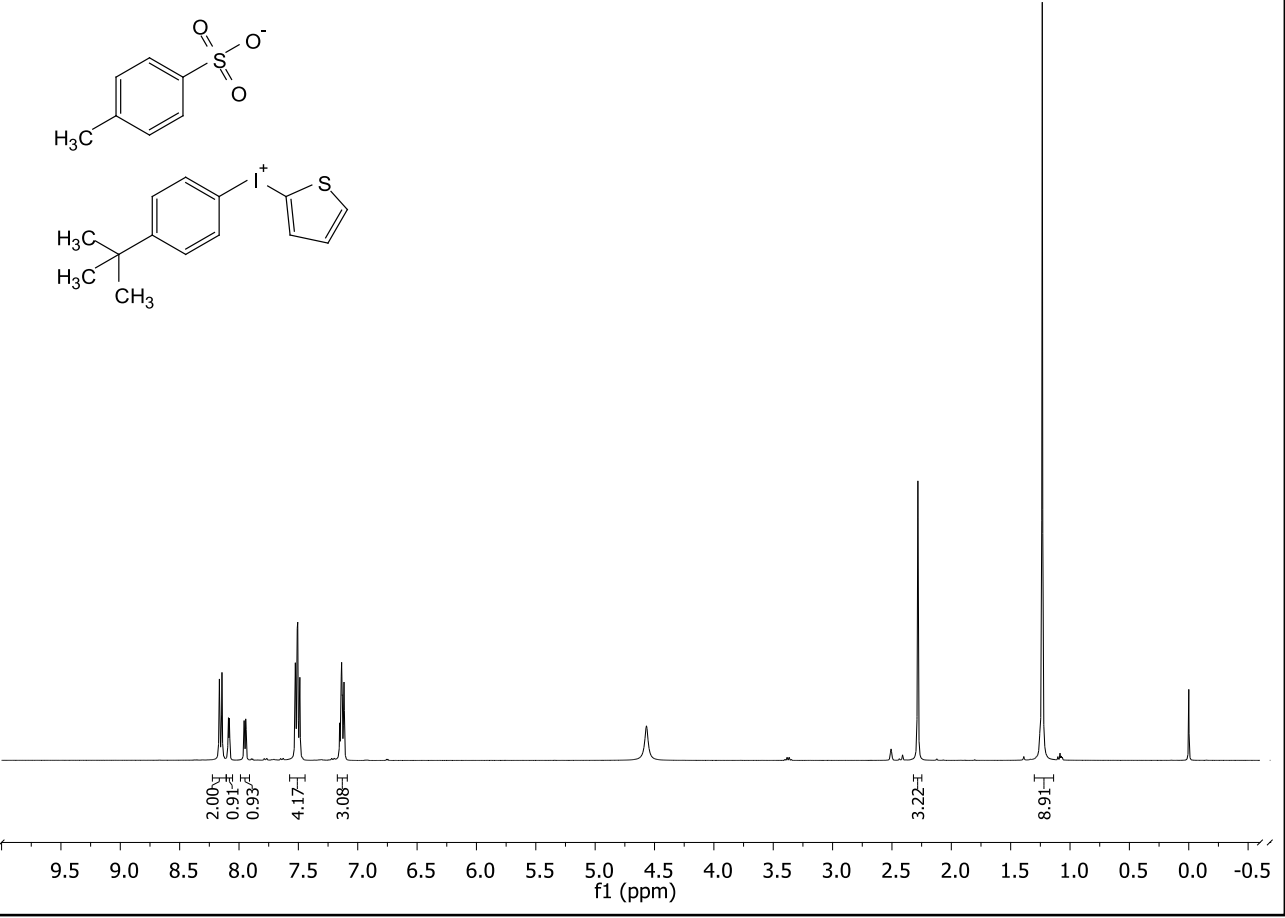

- ${ }^{13} \mathrm{C}$ NMR spectrum of $\mathbf{1 2}$ at $101 \mathrm{MHz}$ in DMSO- $d_{6}$ at $298 \mathrm{~K}$

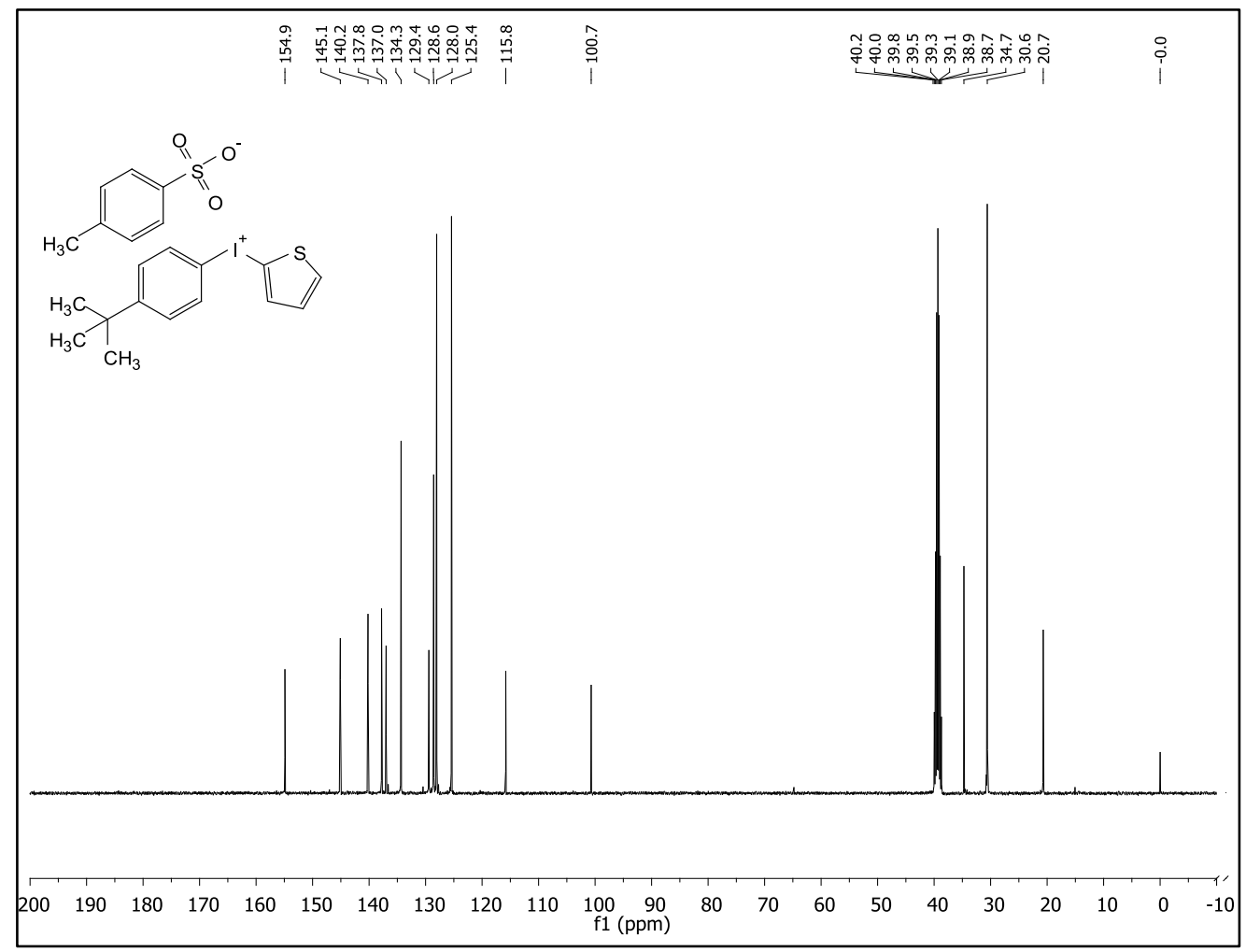


- ${ }^{1} \mathrm{H}$ NMR spectrum of $\mathbf{1 3}$ at $400 \mathrm{MHz}$ in DMSO- $d_{6}$ at $298 \mathrm{~K}$

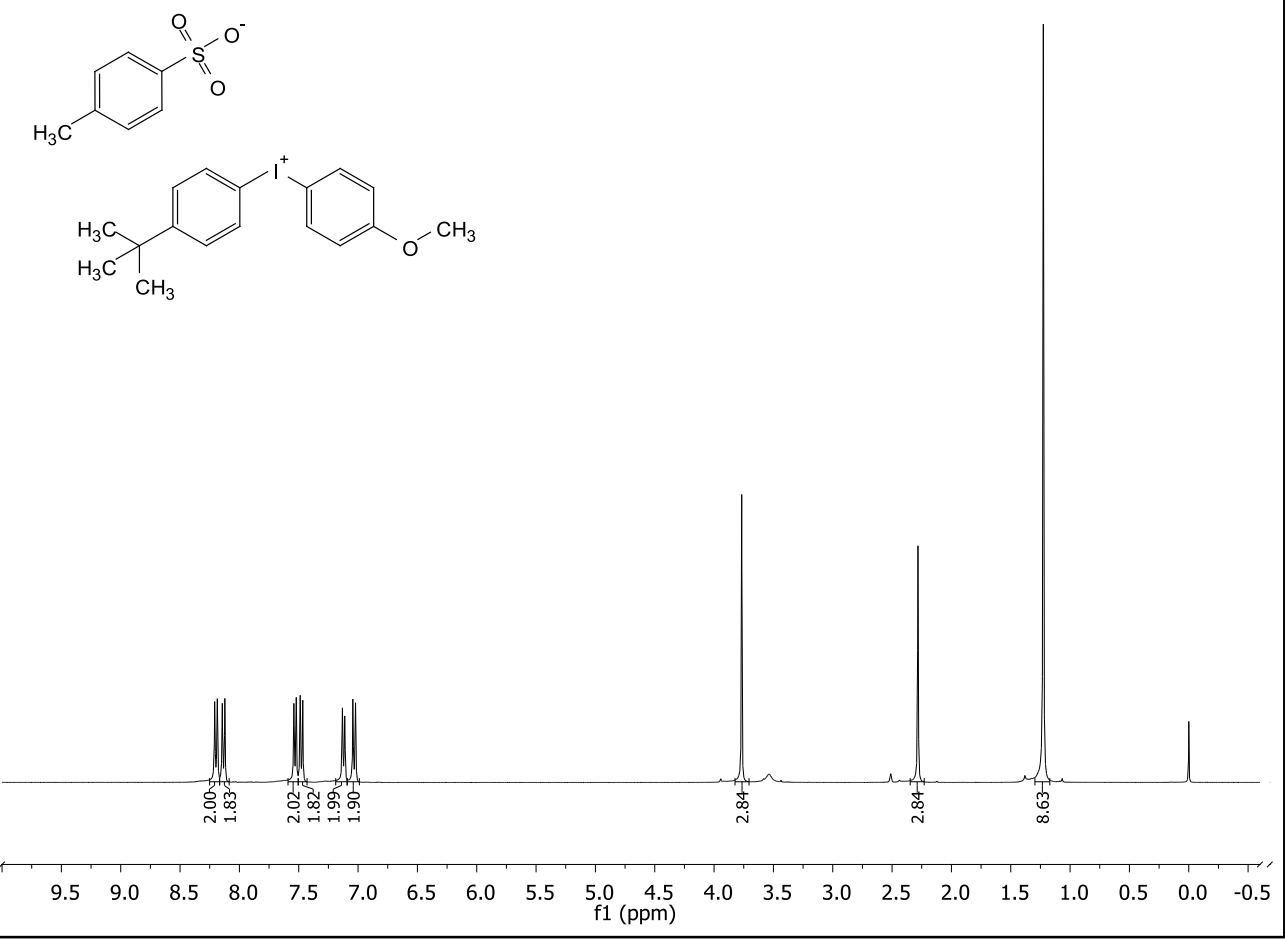

- ${ }^{13} \mathrm{C}$ NMR spectrum of $\mathbf{1 3}$ at $101 \mathrm{MHz}$ in DMSO- $d_{6}$ at $298 \mathrm{~K}$

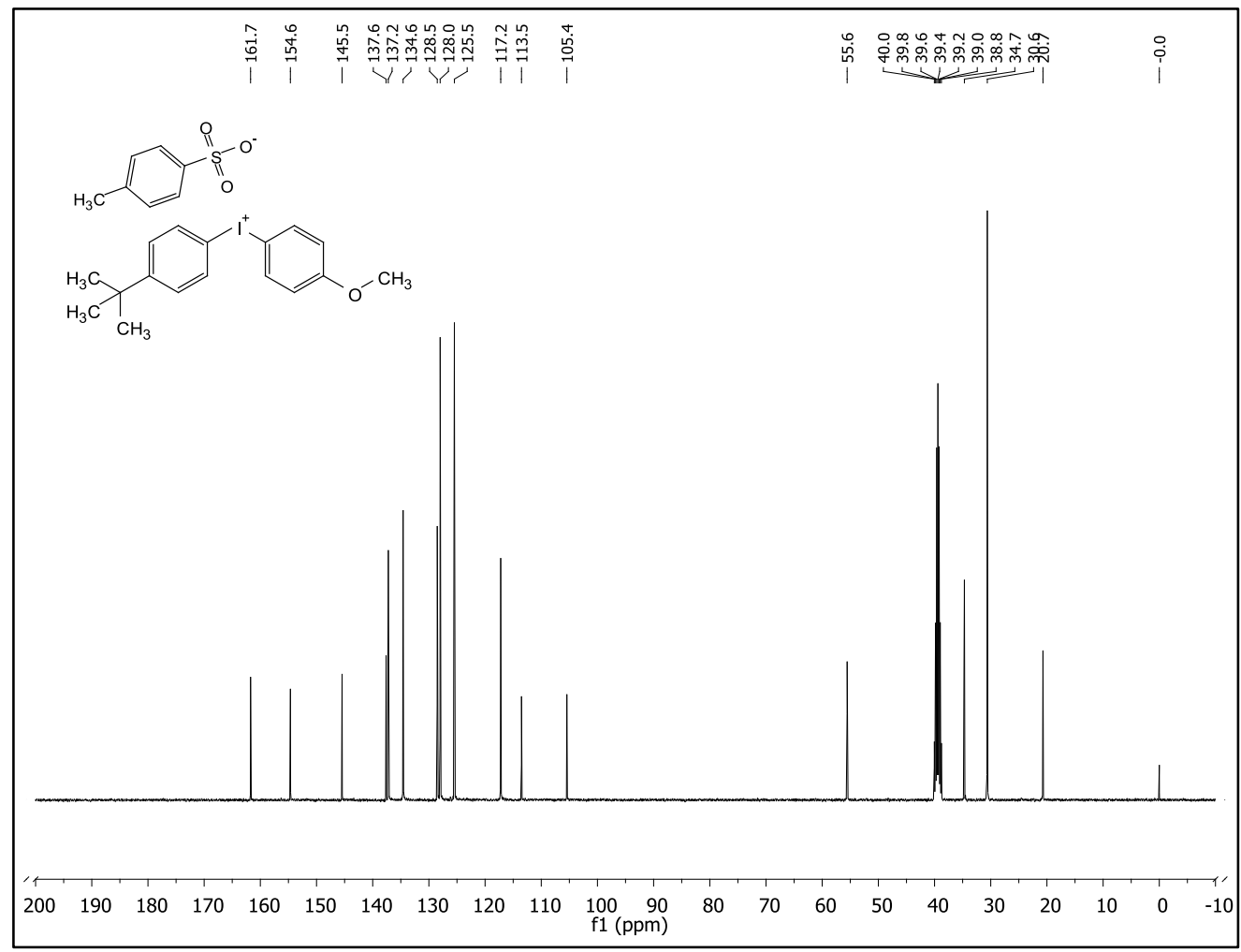


- ${ }^{1} \mathrm{H}$ NMR spectrum of $\mathbf{1 4}$ at $400 \mathrm{MHz}$ in DMSO- $d_{6}$ at $298 \mathrm{~K}$
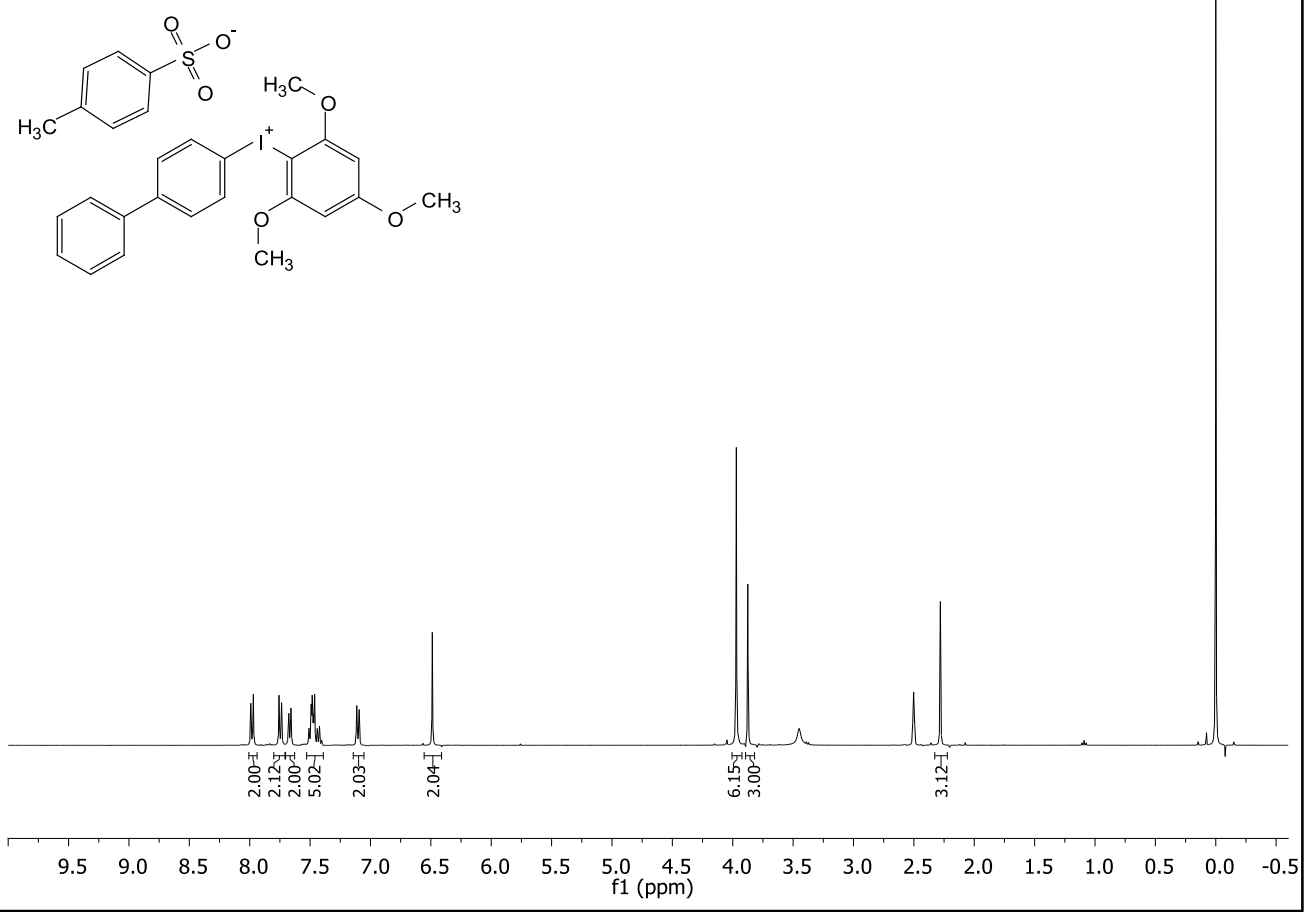

- ${ }^{13} \mathrm{C}$ NMR spectrum of $\mathbf{1 4}$ at $101 \mathrm{MHz}$ in DMSO- $d_{6}$ at $298 \mathrm{~K}$

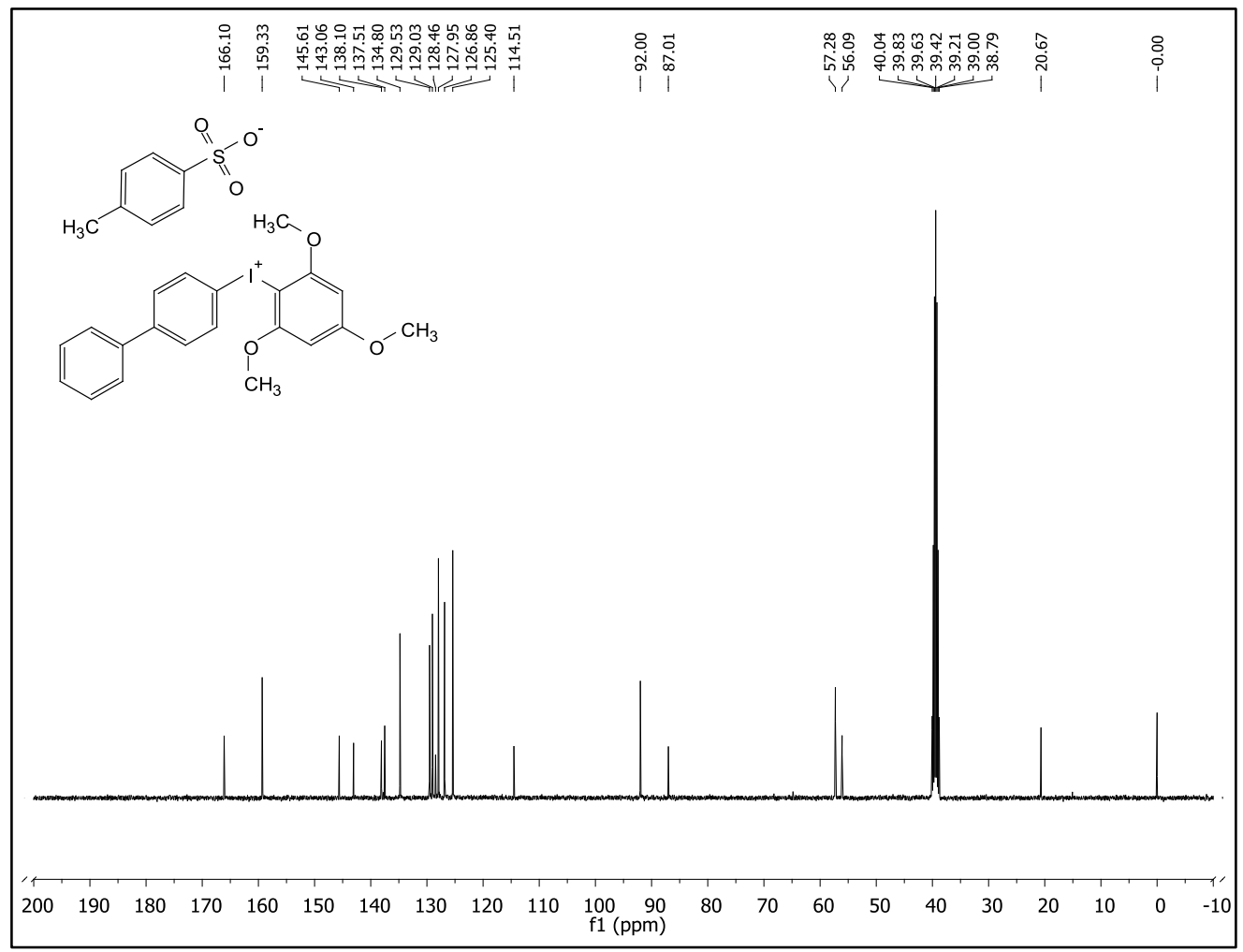


- ${ }^{1} \mathrm{H}$ NMR spectrum of $\mathbf{1 5}$ at $400 \mathrm{MHz}$ in DMSO- $d_{6}$ at $298 \mathrm{~K}$

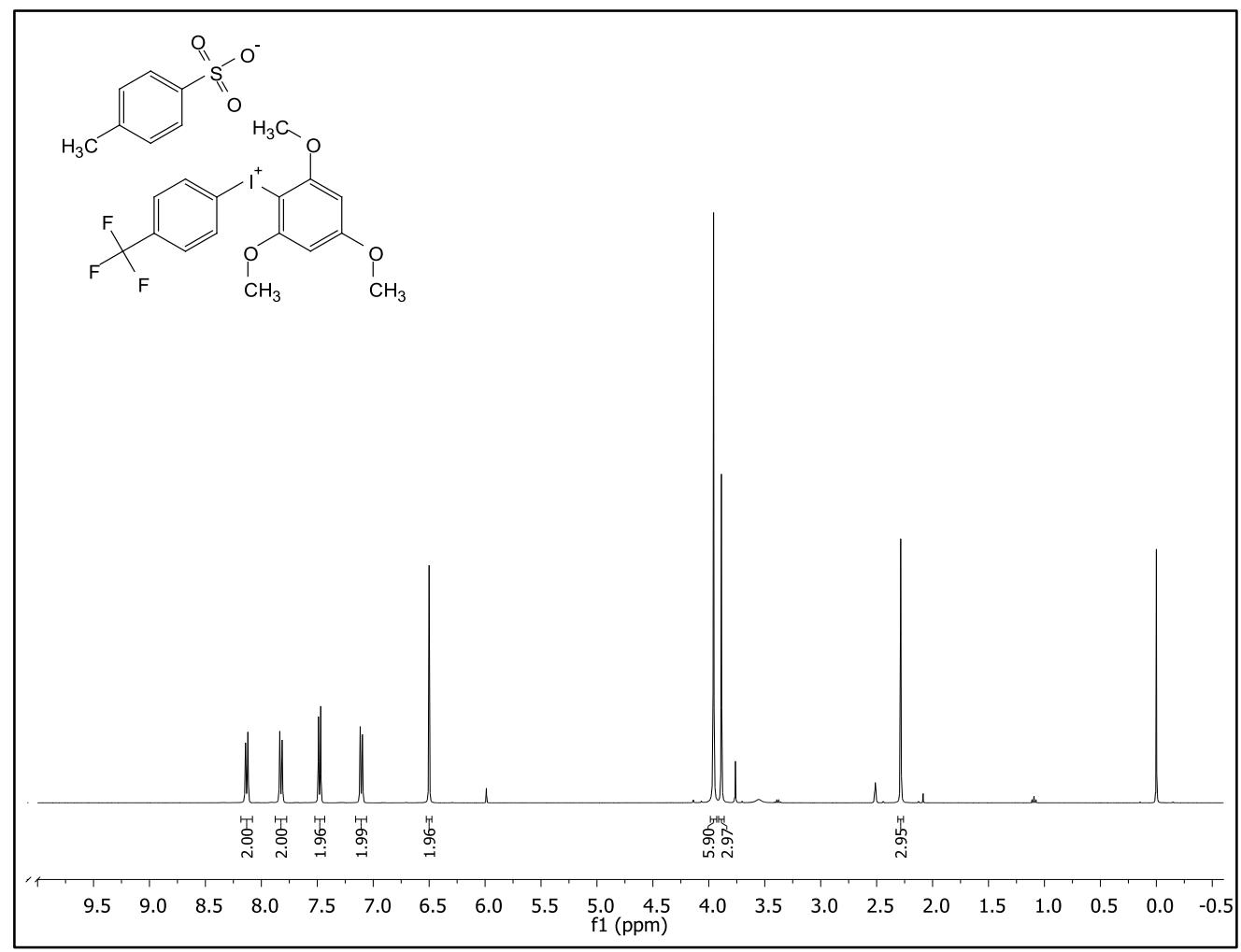

- ${ }^{13} \mathrm{C}$ NMR spectrum of $\mathbf{1 5}$ at $101 \mathrm{MHz}$ in DMSO- $d_{6}$ at $298 \mathrm{~K}$

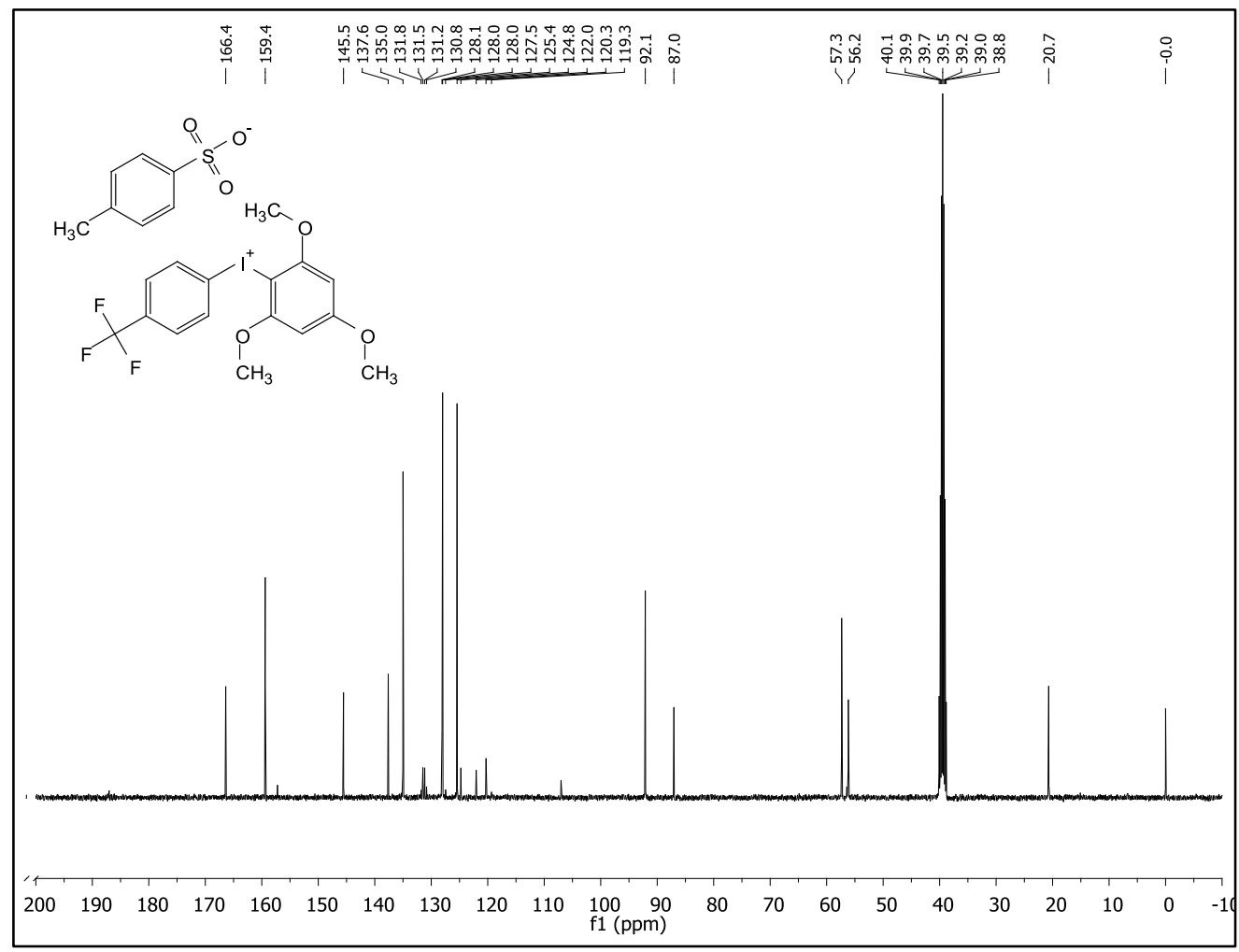


- ${ }^{19}$ F NMR spectrum of $\mathbf{1 5}$ at $376 \mathrm{MHz}$ in DMSO- $d_{6}$ at $298 \mathrm{~K}$

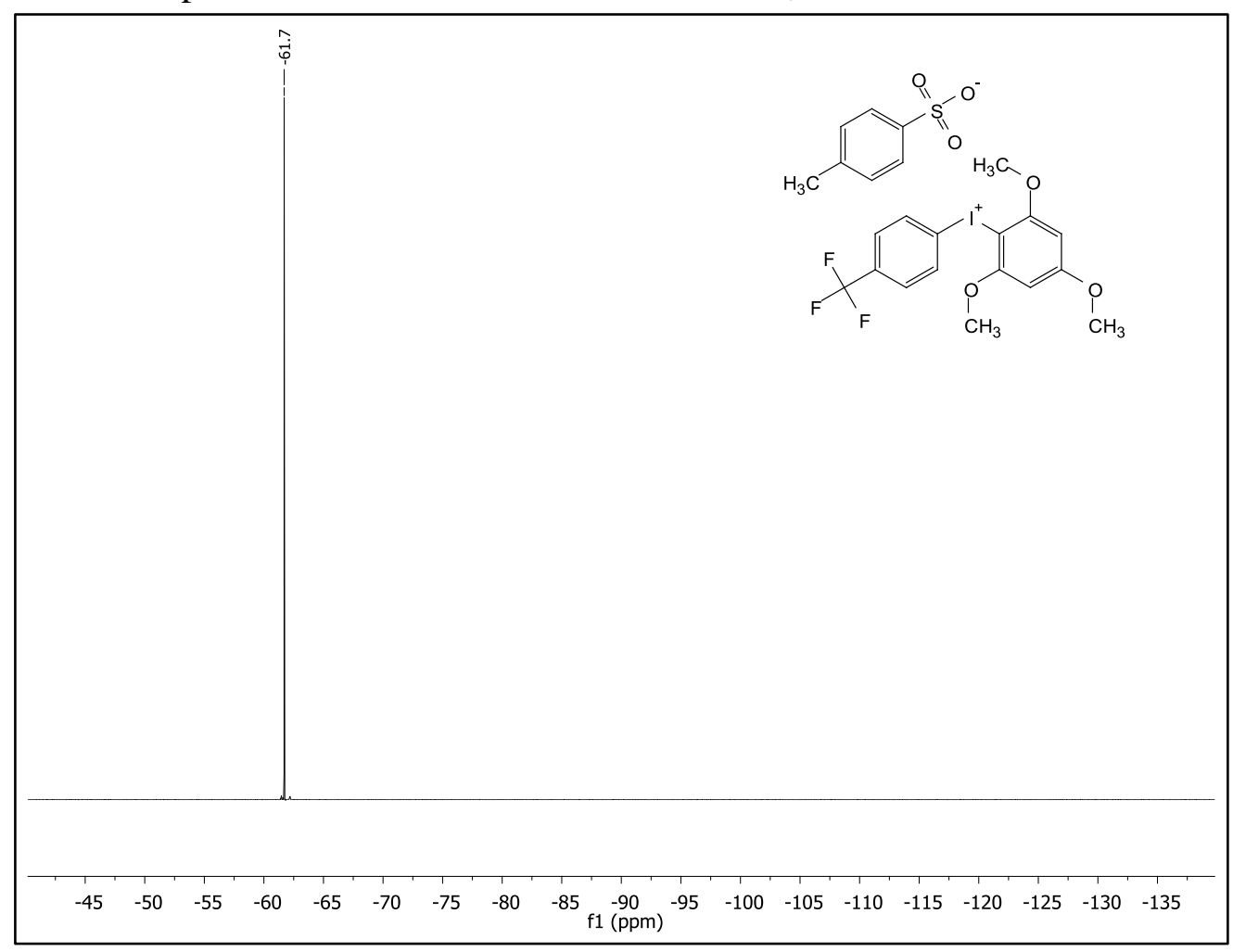

- ${ }^{1} \mathrm{H}$ NMR spectrum of $\mathbf{1 6}$ at $400 \mathrm{MHz}$ in DMSO- $d_{6}$ at $298 \mathrm{~K}$

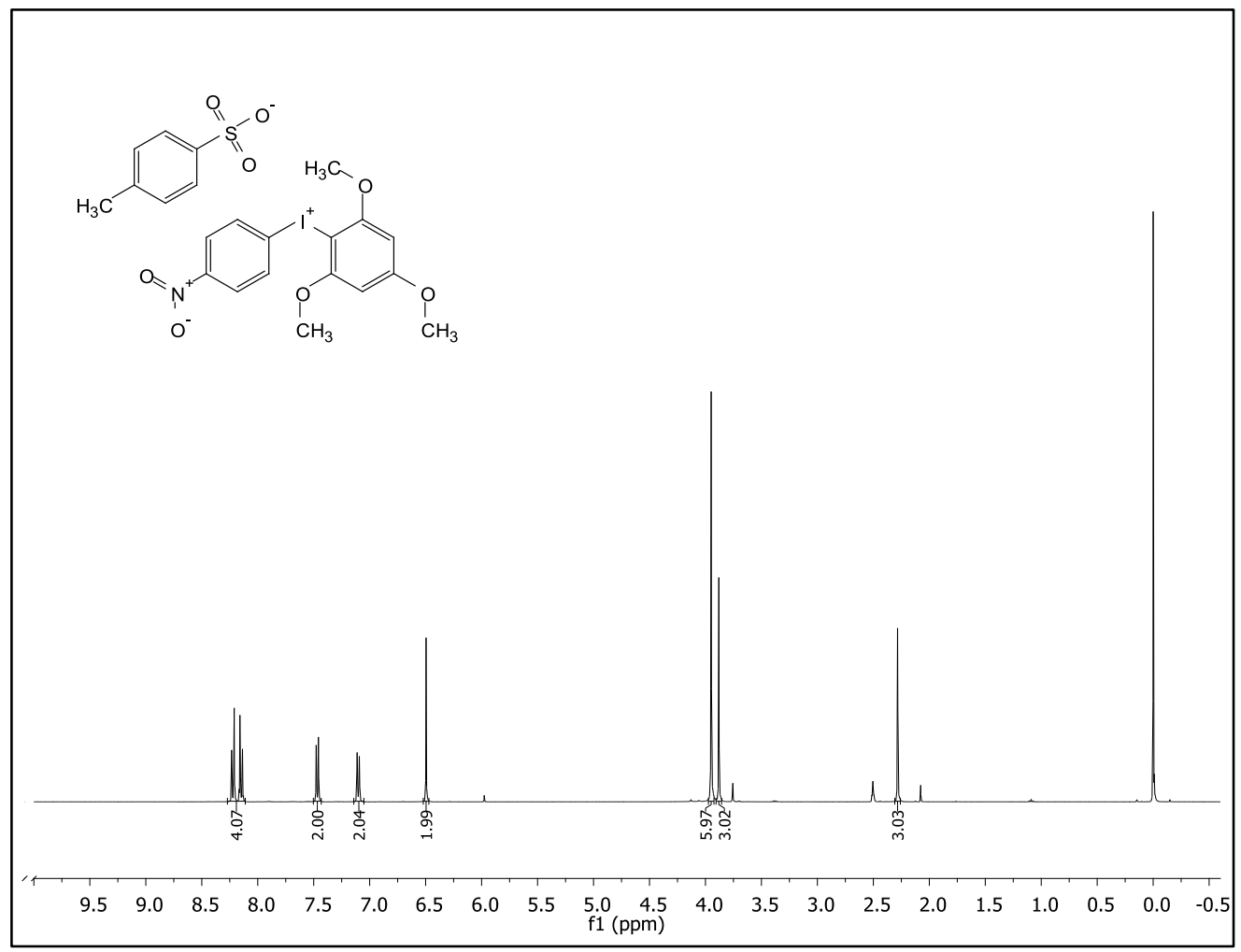


- ${ }^{13} \mathrm{C}$ NMR spectrum of $\mathbf{1 6}$ at $101 \mathrm{MHz}$ in DMSO- $d_{6}$ at $298 \mathrm{~K}$

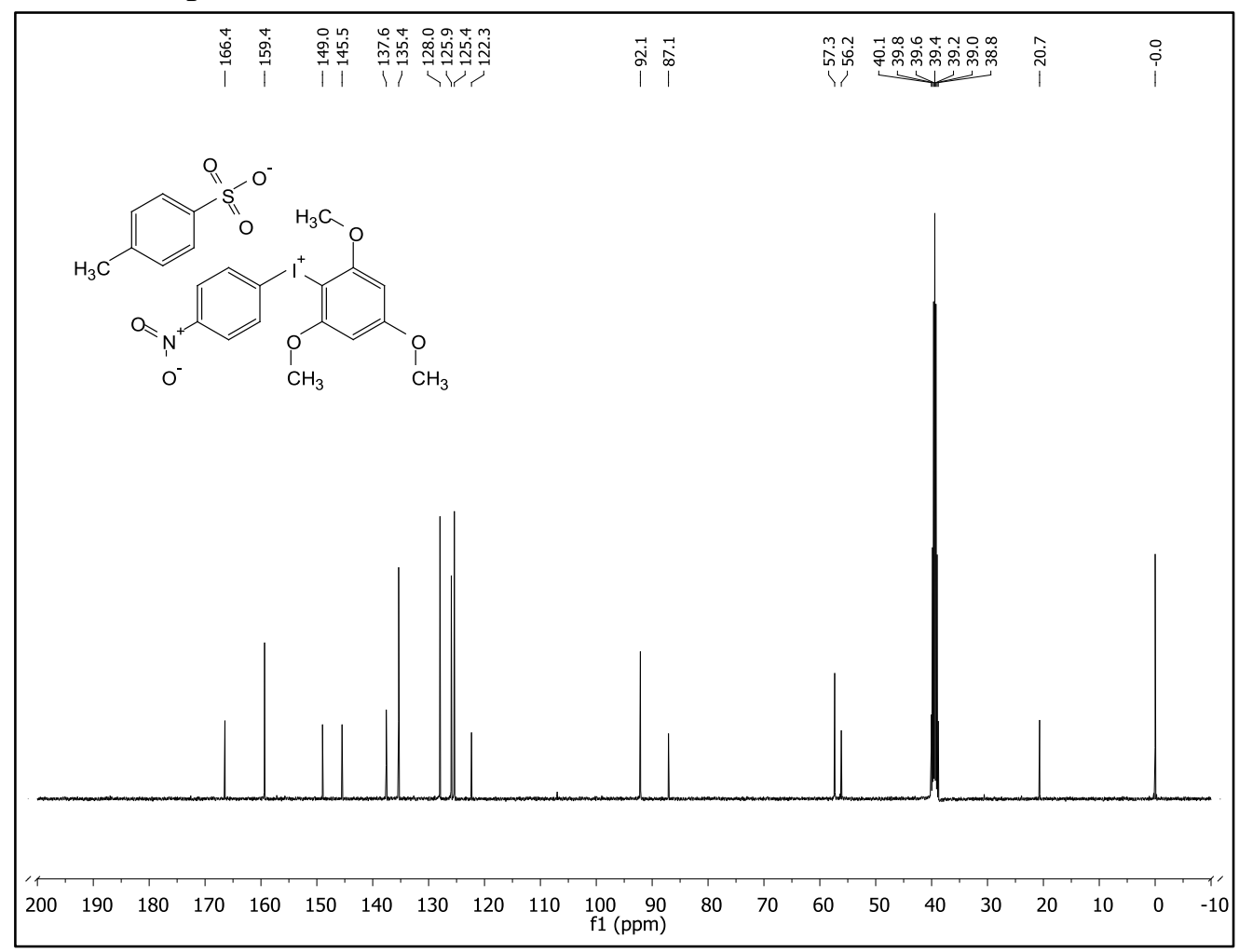

- ${ }^{1} \mathrm{H}$ NMR spectrum of $\mathbf{1 7}$ at $400 \mathrm{MHz}$ in DMSO- $d_{6}$ at $298 \mathrm{~K}$

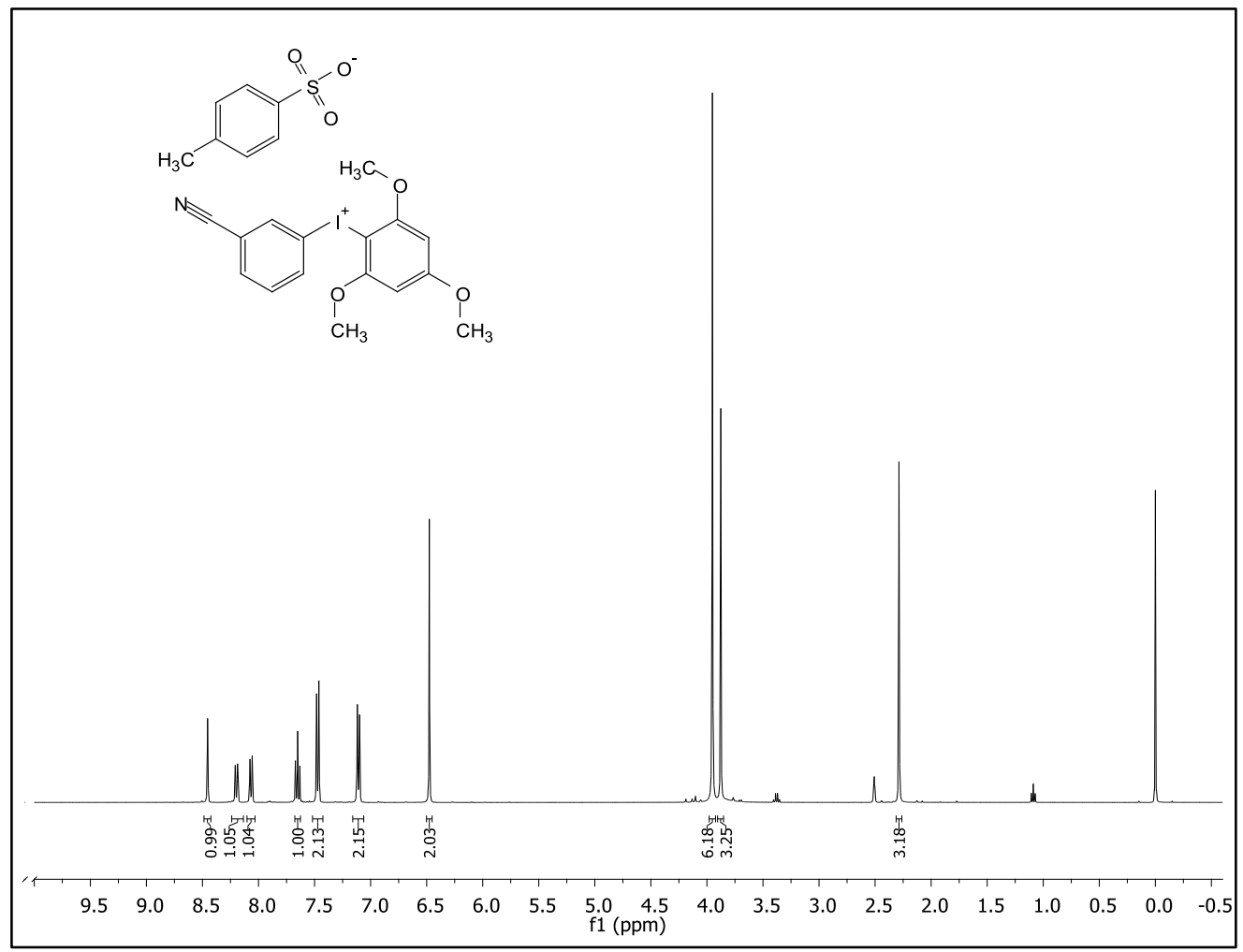


- ${ }^{13} \mathrm{C}$ NMR spectrum of $\mathbf{1 7}$ at $101 \mathrm{MHz}$ in DMSO- $d_{6}$ at $298 \mathrm{~K}$

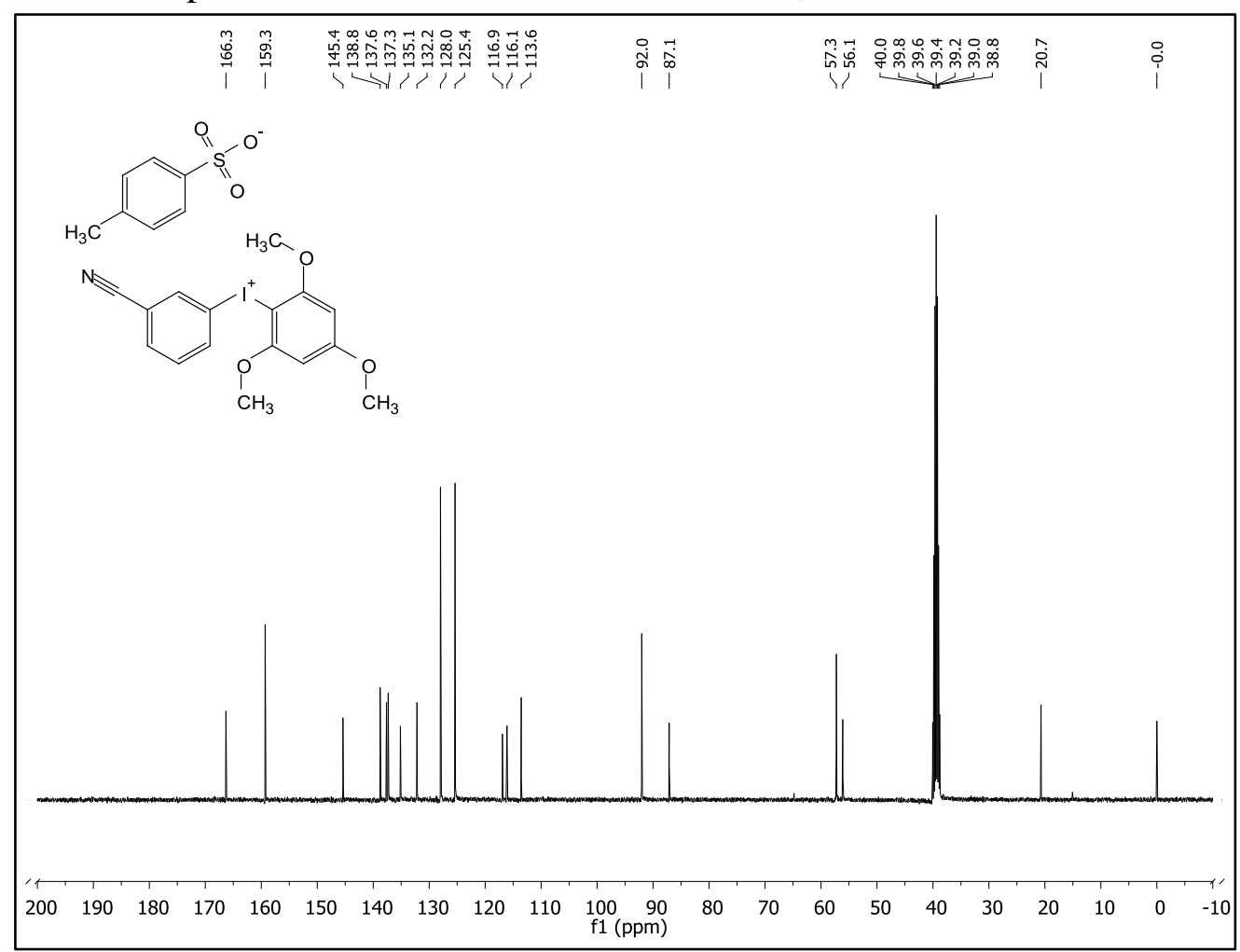

- ${ }^{1} \mathrm{H}$ NMR spectrum of $\mathbf{1 8}$ at $400 \mathrm{MHz}$ in DMSO- $d_{6}$ at $298 \mathrm{~K}$
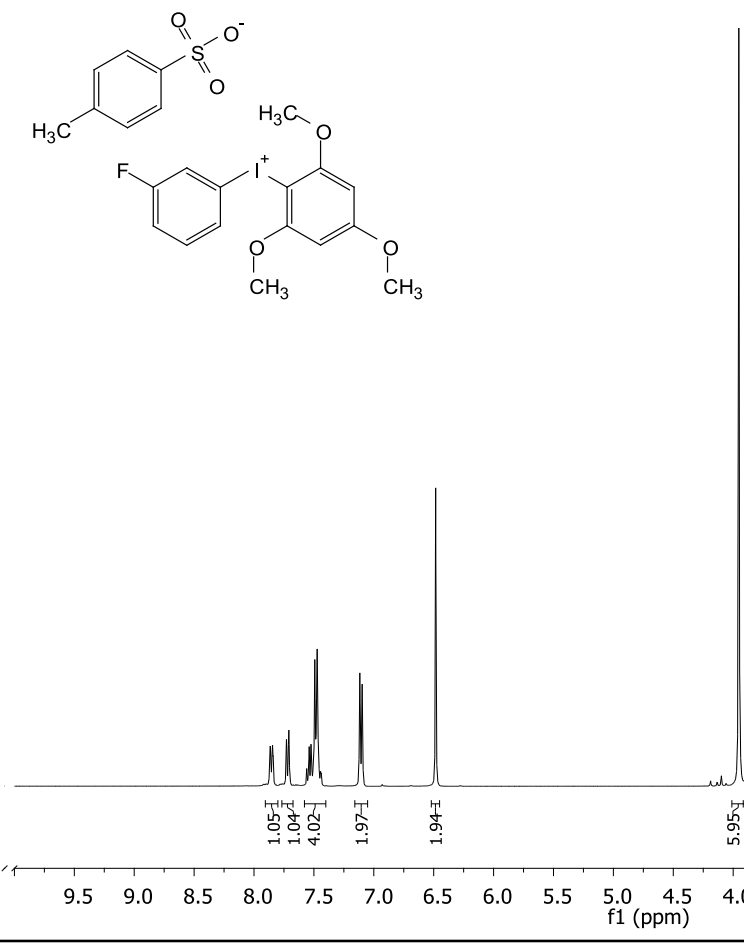
- ${ }^{13} \mathrm{C}$ NMR spectrum of $\mathbf{1 8}$ at $101 \mathrm{MHz}$ in DMSO- $d_{6}$ at $298 \mathrm{~K}$

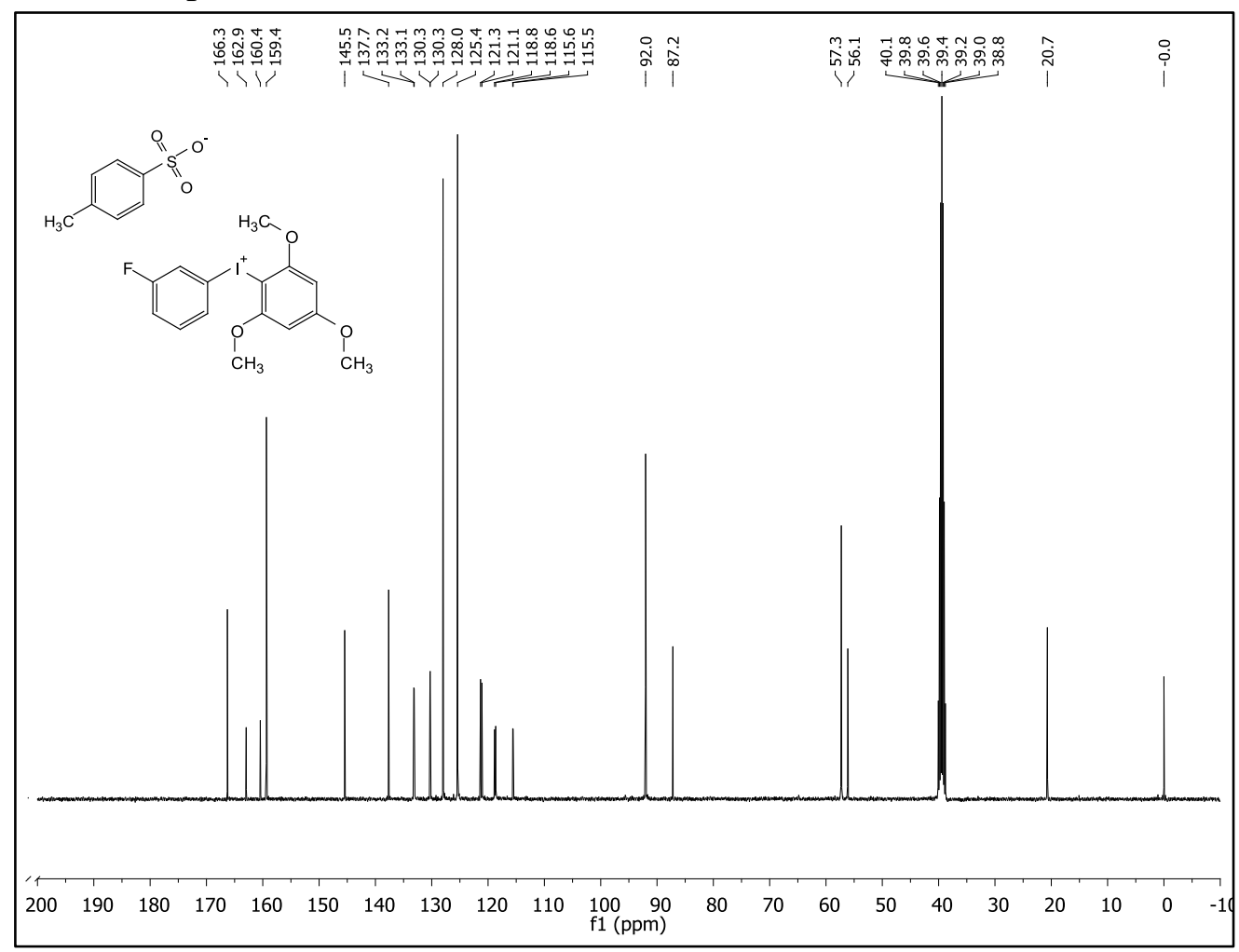

- ${ }^{19}$ F NMR spectrum of $\mathbf{1 8}$ at $376 \mathrm{MHz}$ in DMSO- $d_{6}$ at $298 \mathrm{~K}$

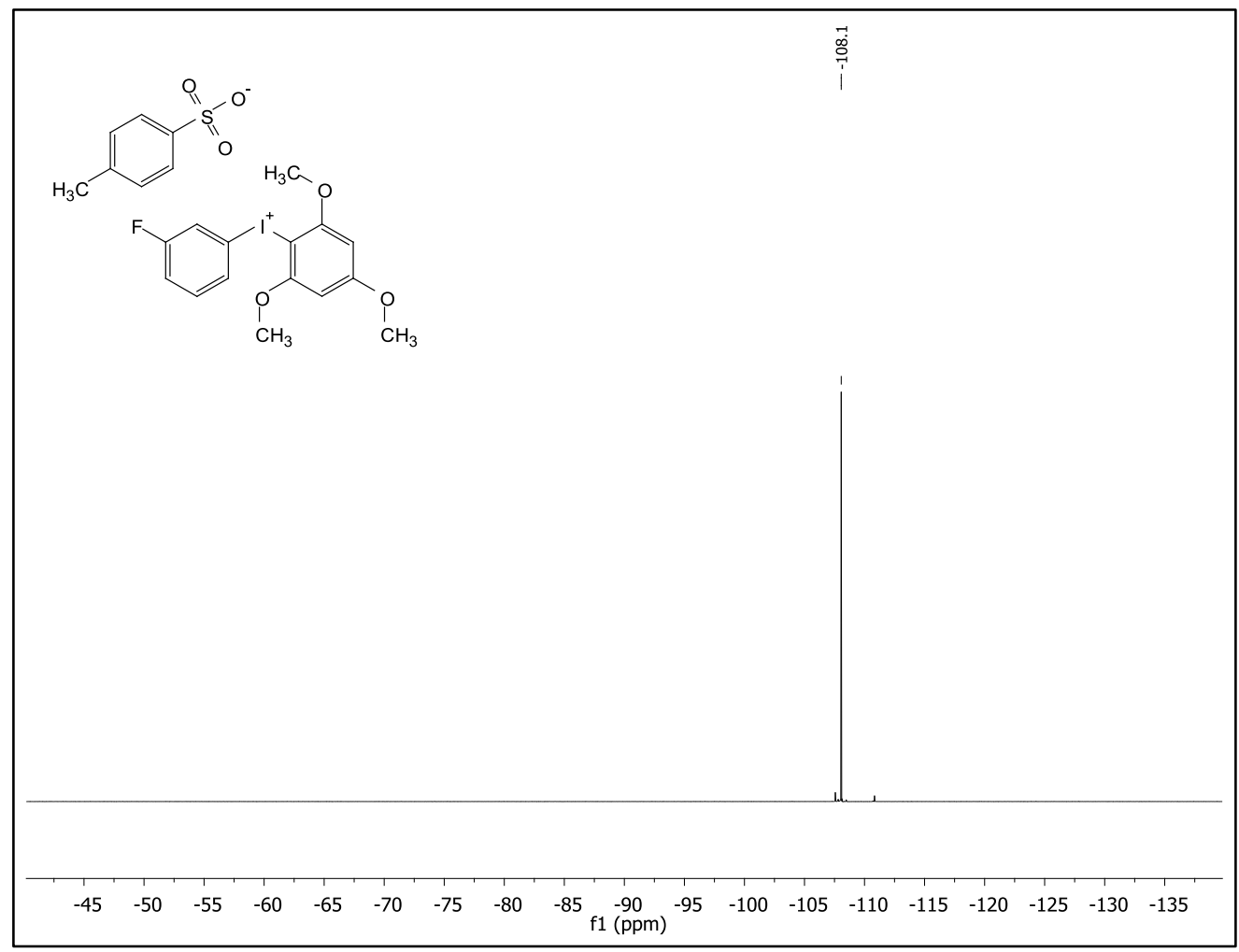


S30

- ${ }^{1} \mathrm{H}$ NMR spectrum of $\mathbf{1 9}$ at $400 \mathrm{MHz}$ in DMSO- $d_{6}$ at $298 \mathrm{~K}$

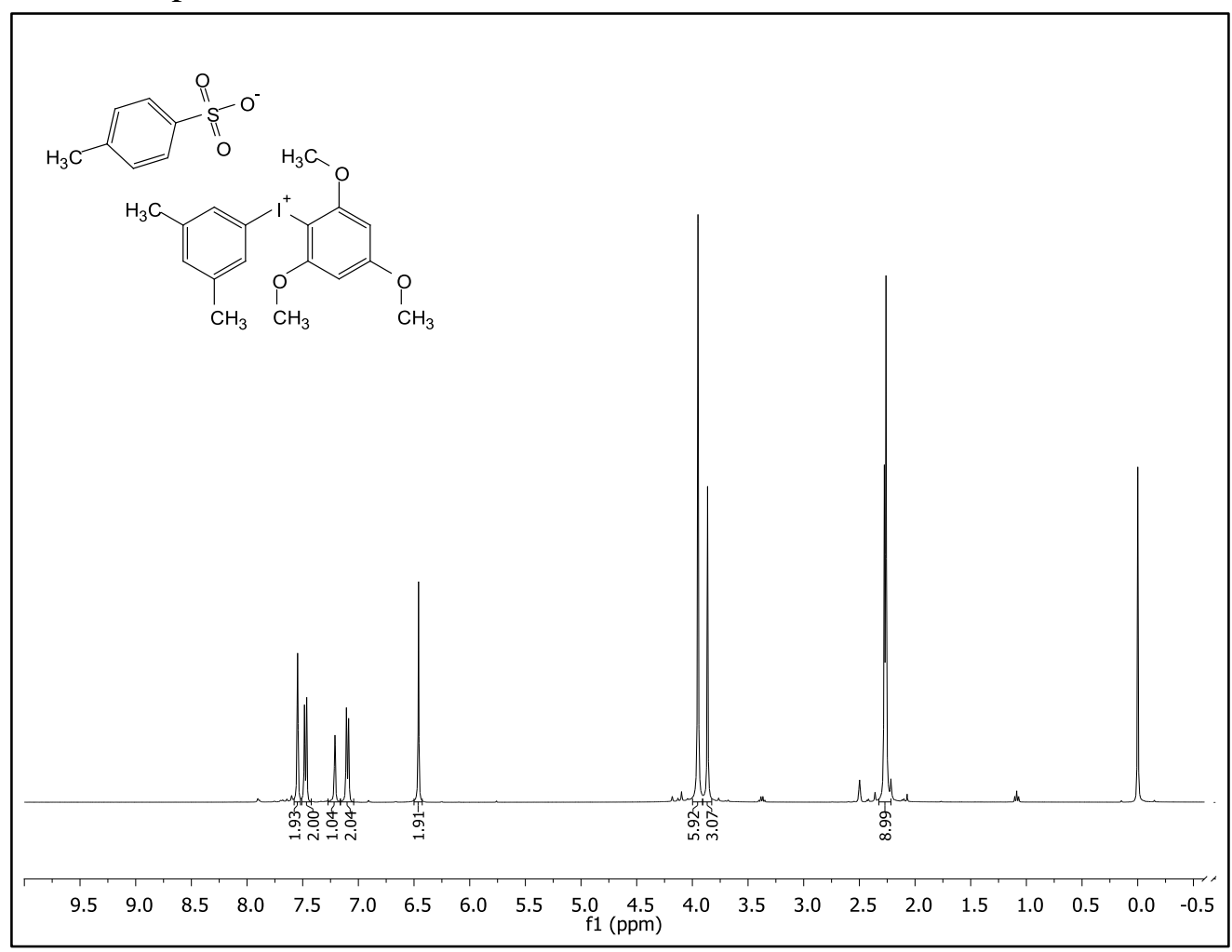

- ${ }^{13} \mathrm{C}$ NMR spectrum of $\mathbf{1 9}$ at $101 \mathrm{MHz}$ in DMSO- $d_{6}$ at $298 \mathrm{~K}$

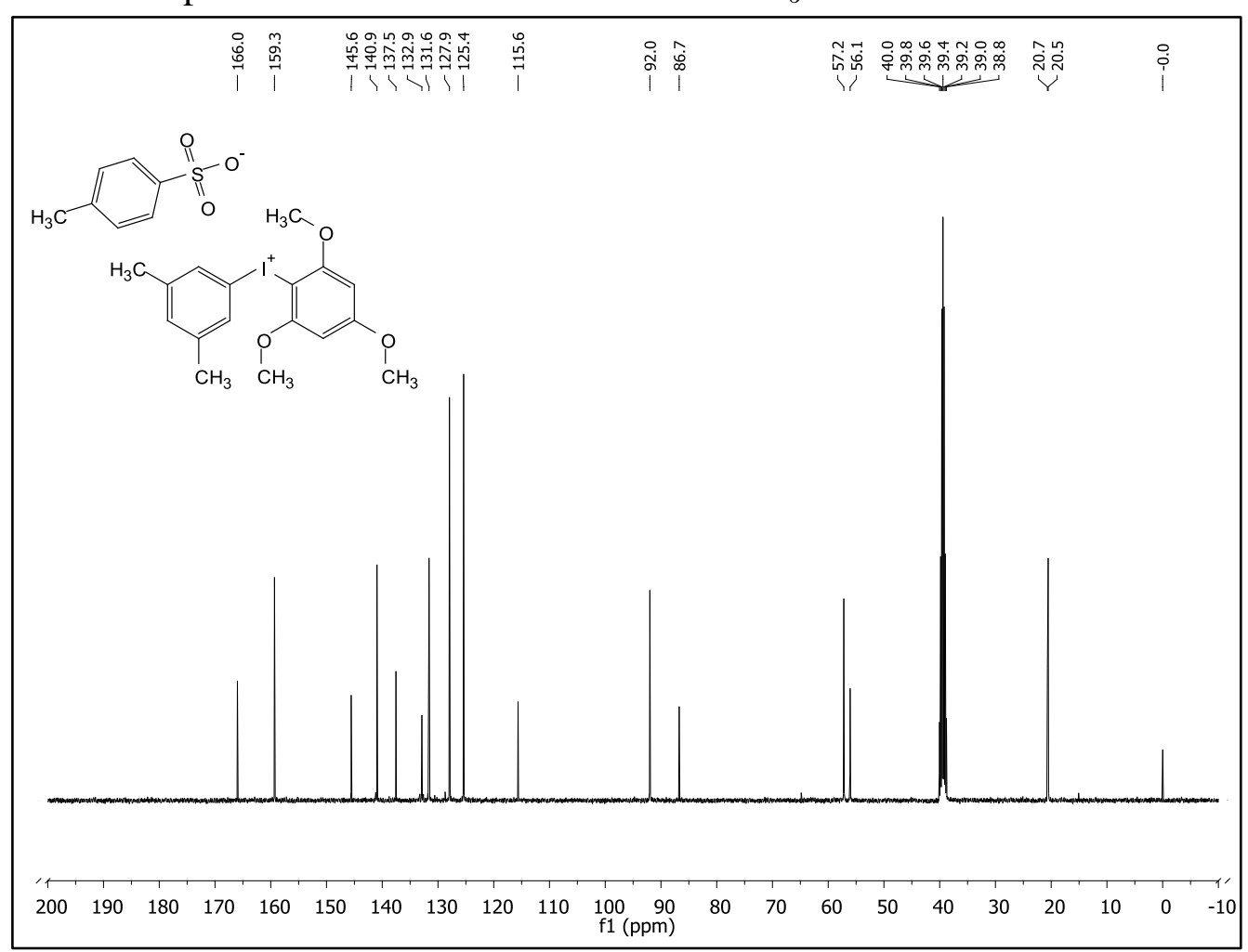


S31

- $\quad{ }^{1} \mathrm{H}$ NMR spectrum of 20 at $400 \mathrm{MHz}$ in DMSO- $d_{6}$ at $298 \mathrm{~K}$

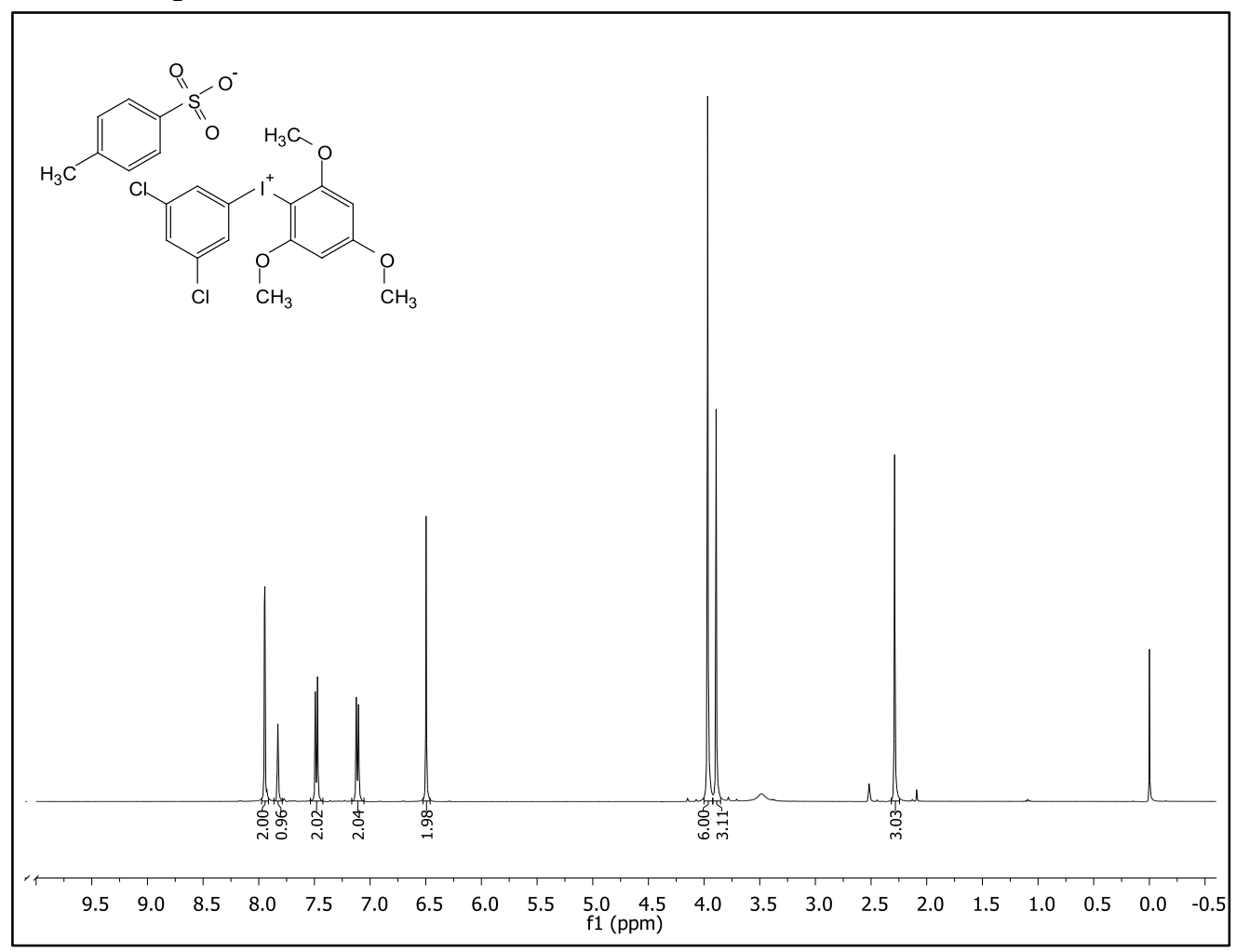

- ${ }^{13} \mathrm{C}$ NMR spectrum of 20 at $101 \mathrm{MHz}$ in DMSO- $d_{6}$ at $298 \mathrm{~K}$

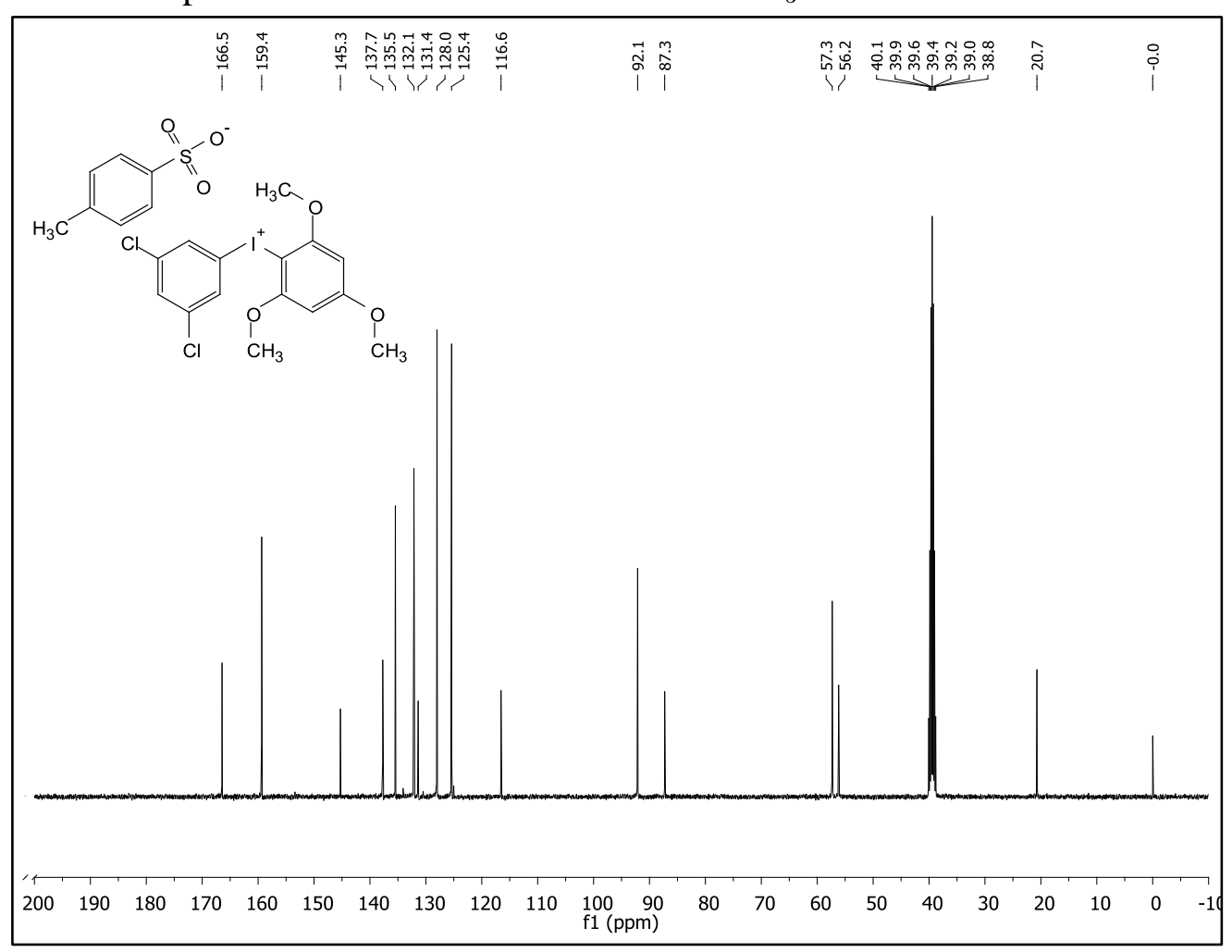


- ${ }^{1} \mathrm{H}$ NMR spectrum of $\mathbf{2 1}$ at $400 \mathrm{MHz}$ in DMSO- $d_{6}$ at $298 \mathrm{~K}$
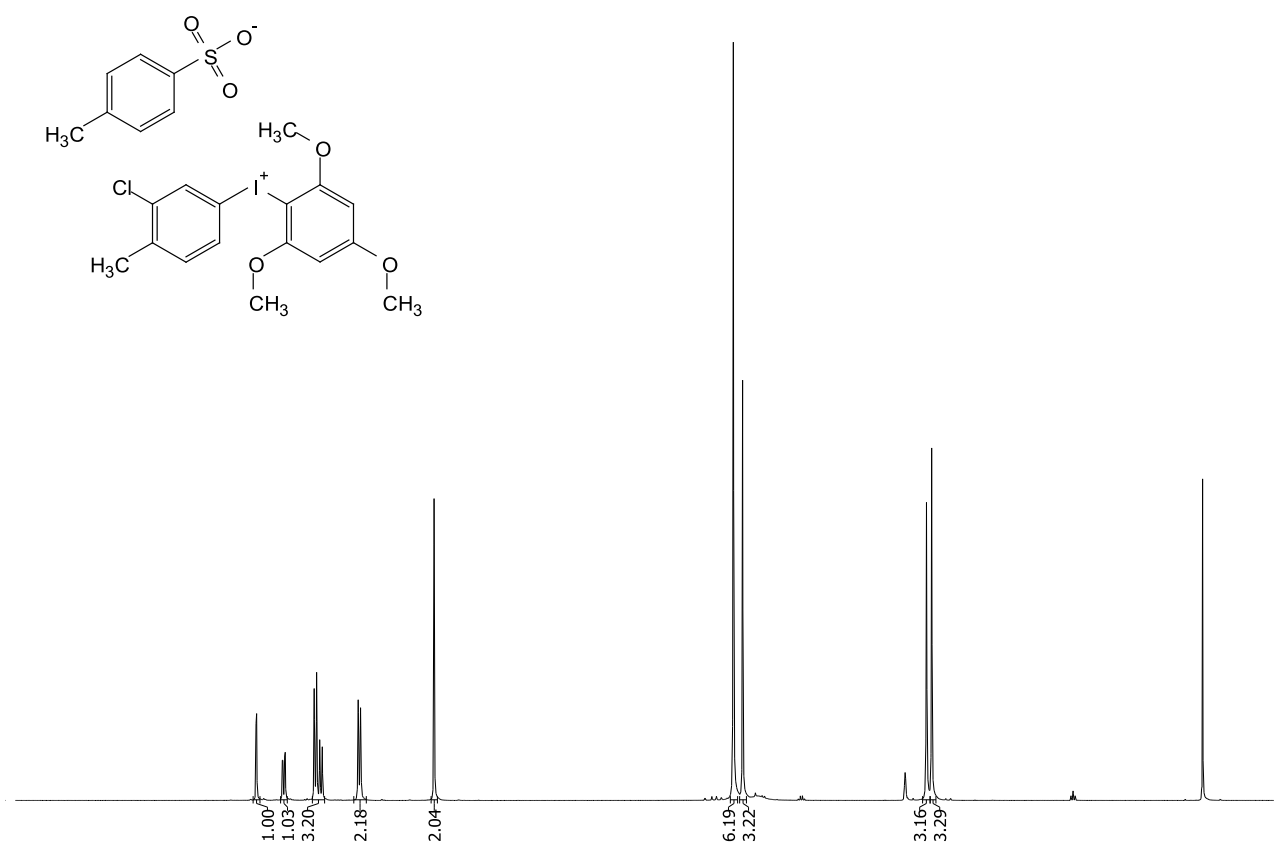

$\begin{array}{lllllllllllllllllllll}9.5 & 9.0 & 8.5 & 8.0 & 7.5 & 7.0 & 6.5 & 6.0 & 5.5 & \begin{array}{r}5.0 \\ \mathrm{f} 1(\mathrm{ppm})\end{array} & 4.0 & 3.5 & 3.0 & 2.5 & 2.0 & 1.5 & 1.0 & 0.5 & 0.0 & -0.5\end{array}$

- ${ }^{13} \mathrm{C}$ NMR spectrum of 21 at $101 \mathrm{MHz}$ in DMSO- $d_{6}$ at $298 \mathrm{~K}$

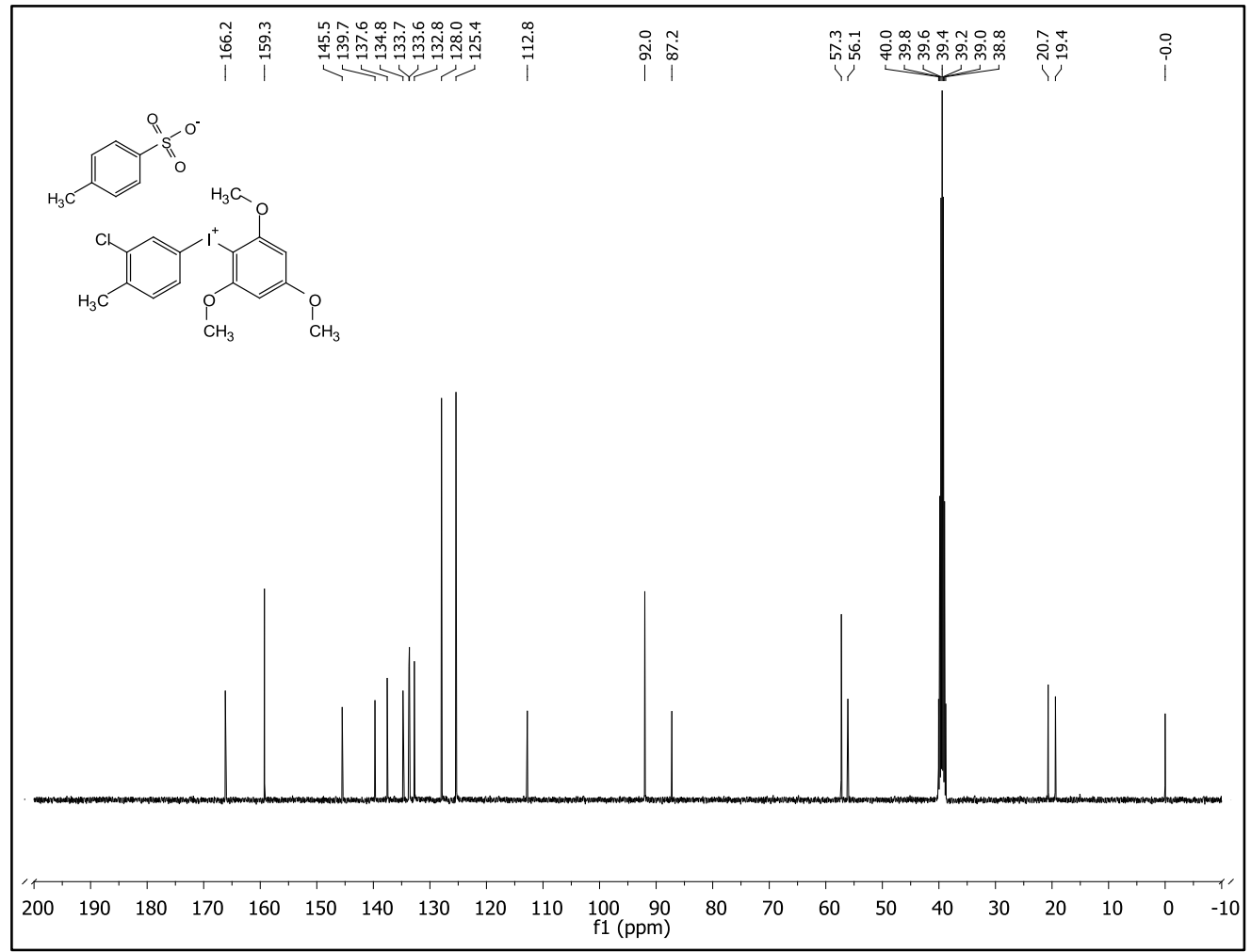


S33

- ${ }^{1} \mathrm{H}$ NMR spectrum of 22 at $400 \mathrm{MHz}$ in DMSO- $d_{6}$ at $298 \mathrm{~K}$

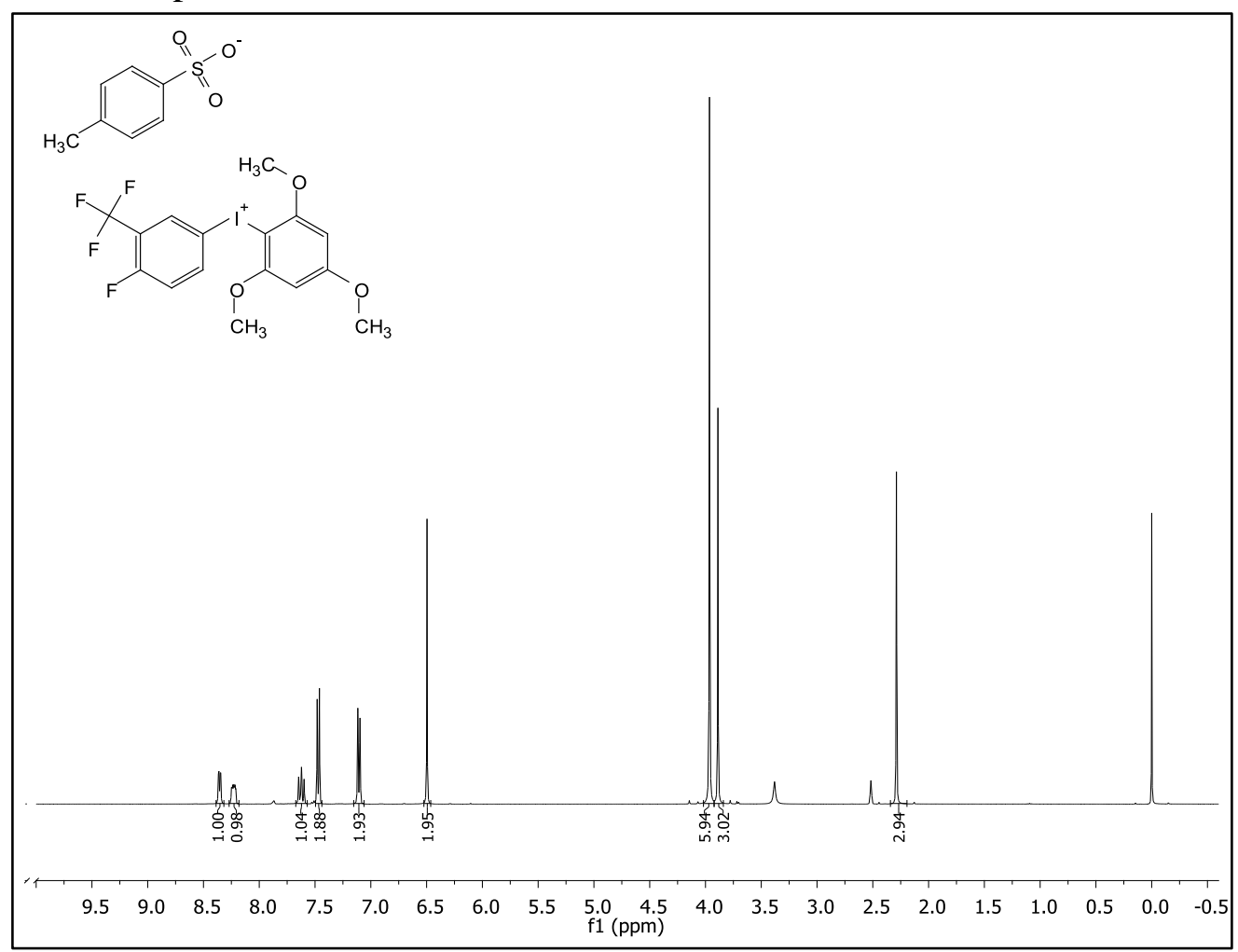

- ${ }^{13} \mathrm{C}$ NMR spectrum of 22 at $101 \mathrm{MHz}$ in DMSO- $d_{6}$ at $298 \mathrm{~K}$

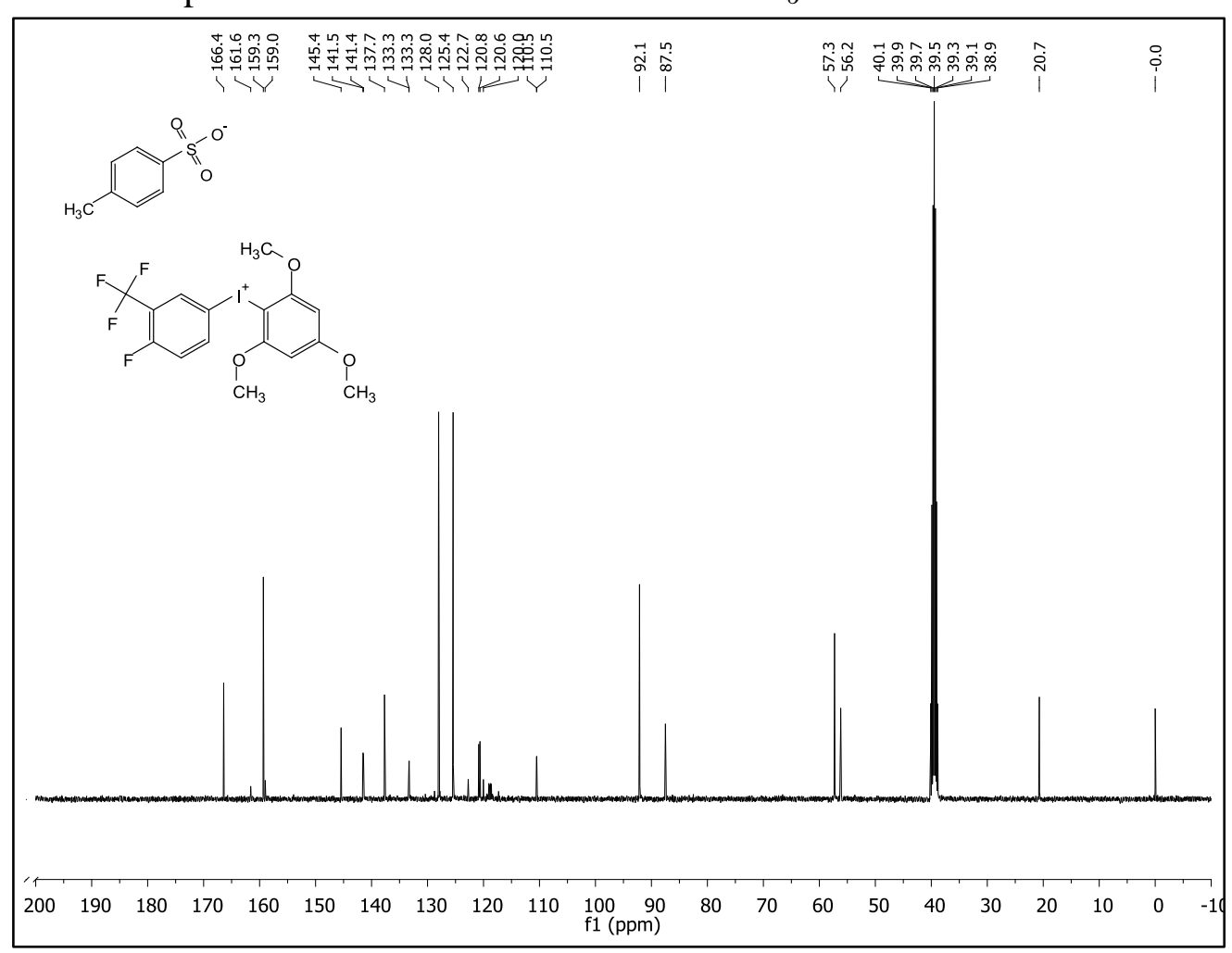


S34

- ${ }^{19} \mathrm{~F}$ NMR spectrum of 22 at $376 \mathrm{MHz}$ in DMSO- $d_{6}$ at $298 \mathrm{~K}$

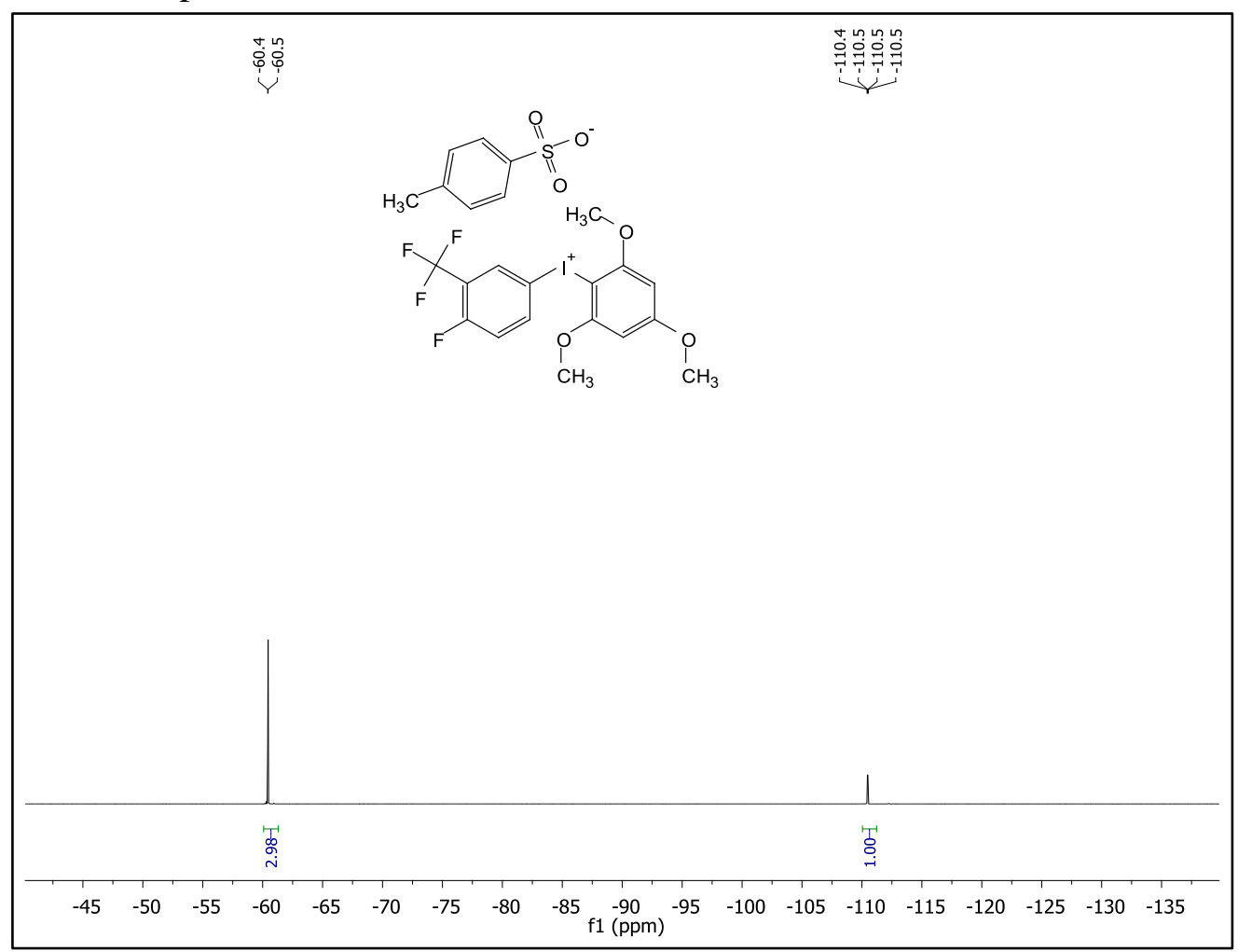

- ${ }^{1} \mathrm{H}$ NMR spectrum of 23 at $400 \mathrm{MHz}$ in DMSO- $d_{6}$ at $298 \mathrm{~K}$

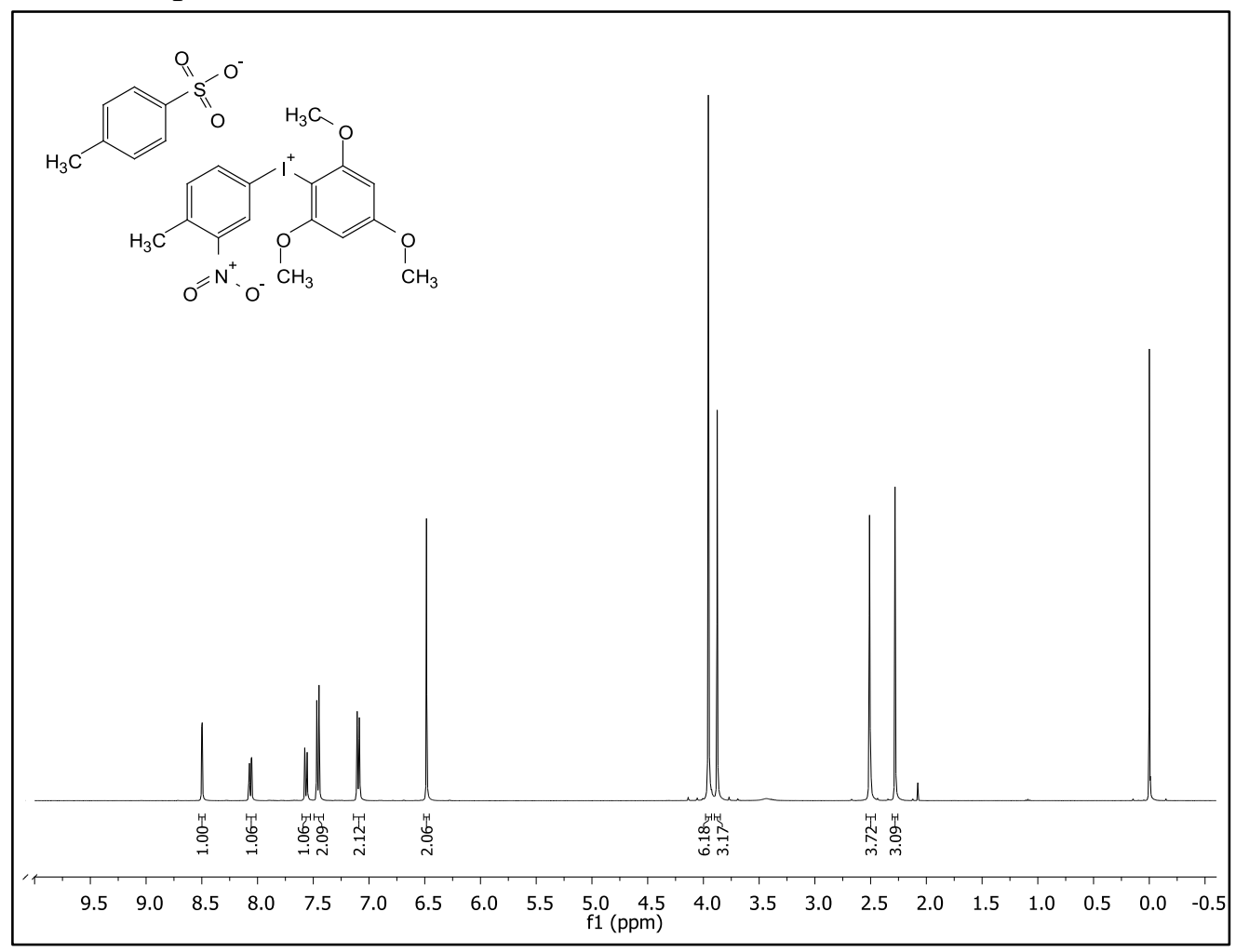


- ${ }^{13} \mathrm{C}$ NMR spectrum of 23 at $101 \mathrm{MHz}$ in DMSO- $d_{6}$ at $298 \mathrm{~K}$

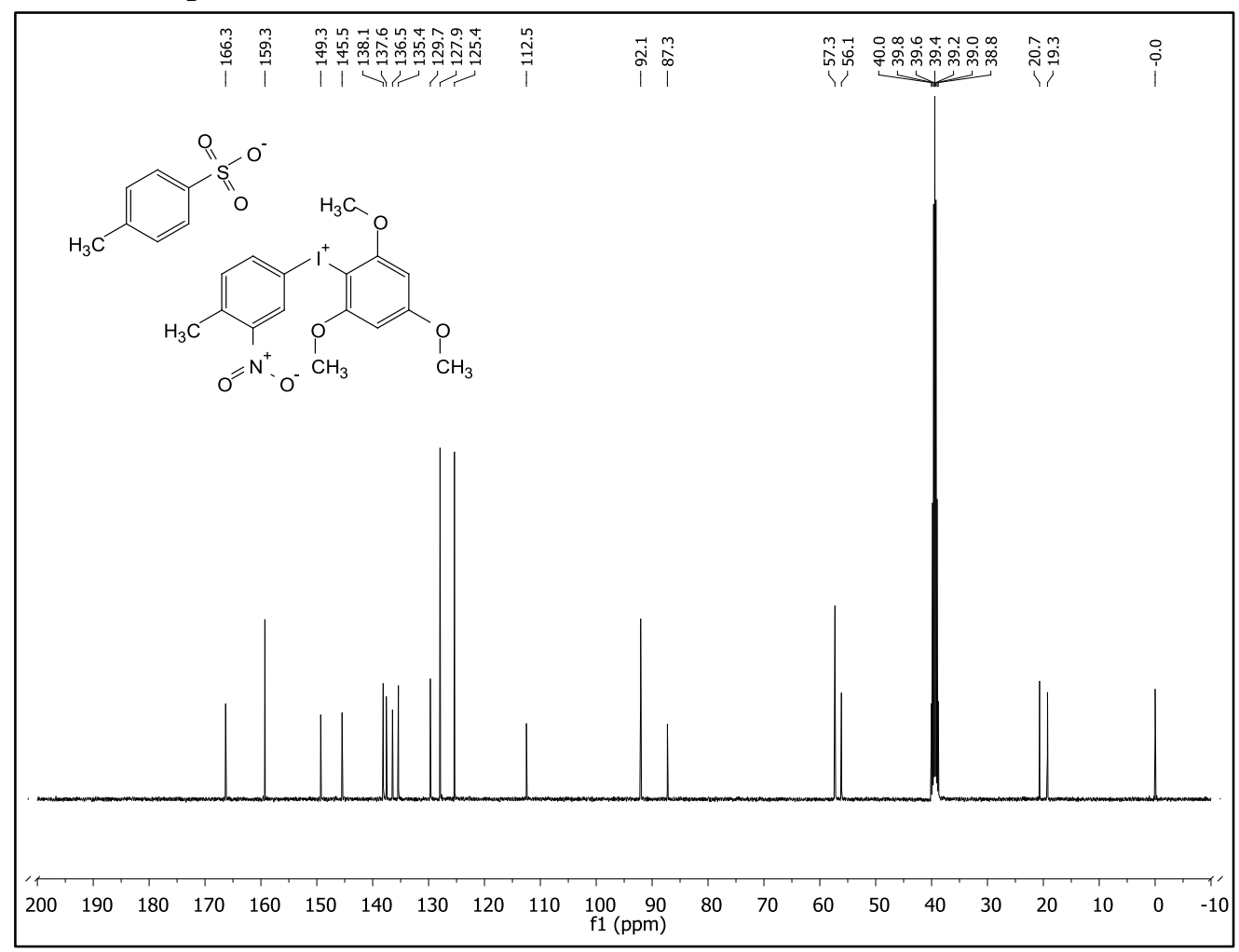

- ${ }^{1} \mathrm{H}$ NMR spectrum of 24 at $400 \mathrm{MHz}$ in DMSO- $d_{6}$ at $298 \mathrm{~K}$

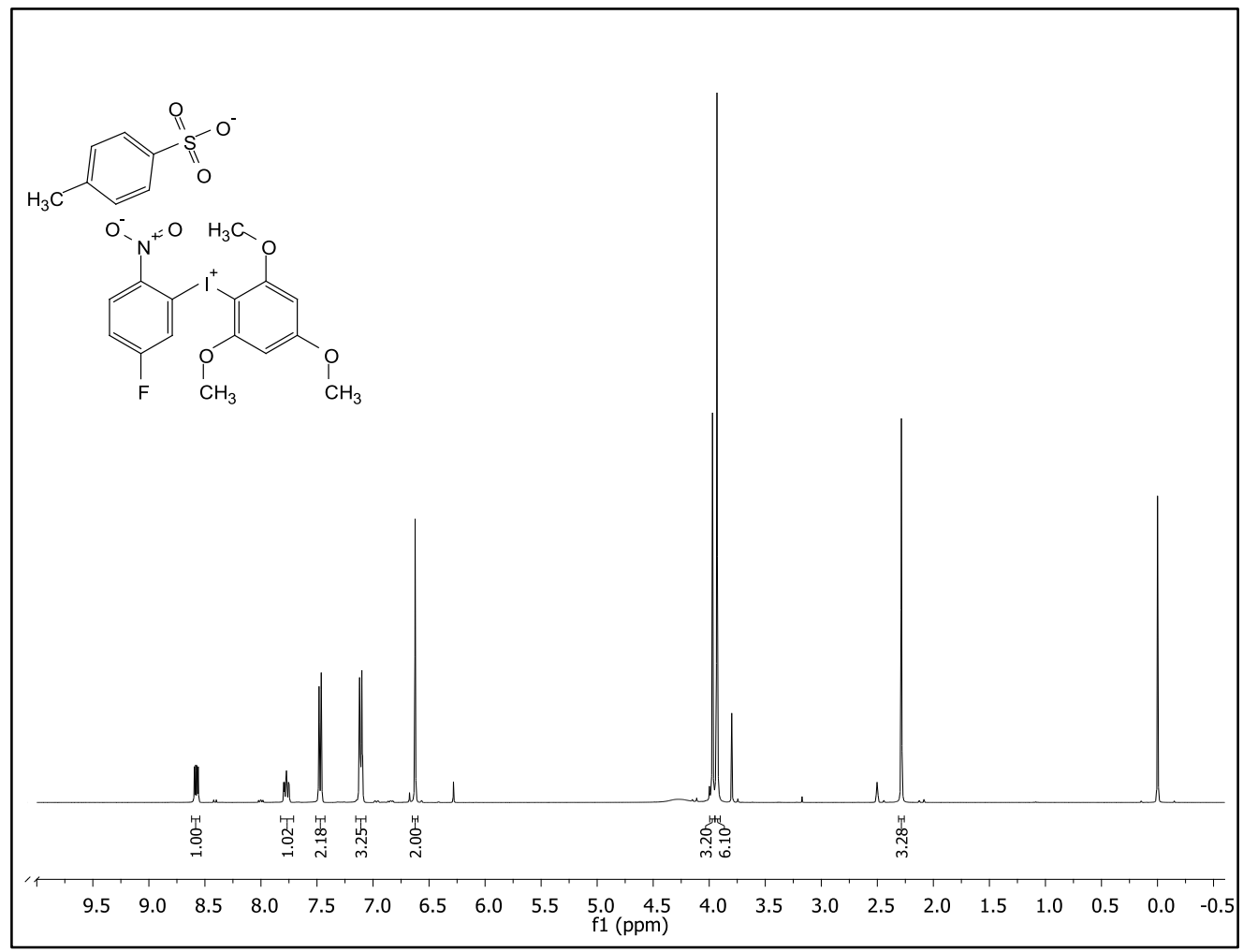


- ${ }^{13} \mathrm{C}$ NMR spectrum of $\mathbf{2 4}$ at $101 \mathrm{MHz}$ in DMSO- $d_{6}$ at $298 \mathrm{~K}$

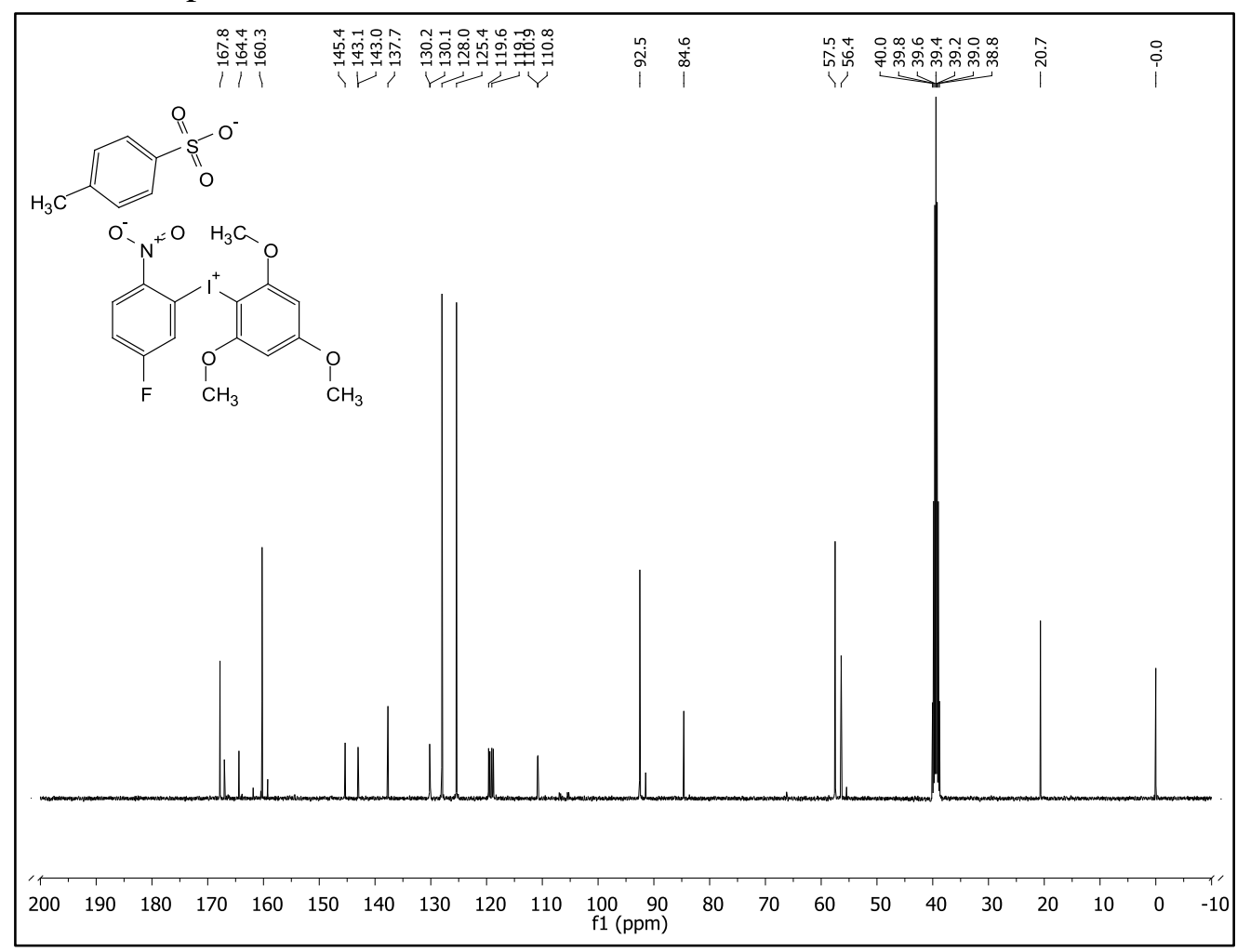

- ${ }^{19} \mathrm{~F}$ NMR spectrum of $\mathbf{2 4}$ at $376 \mathrm{MHz}$ in DMSO- $d_{6}$ at $298 \mathrm{~K}$

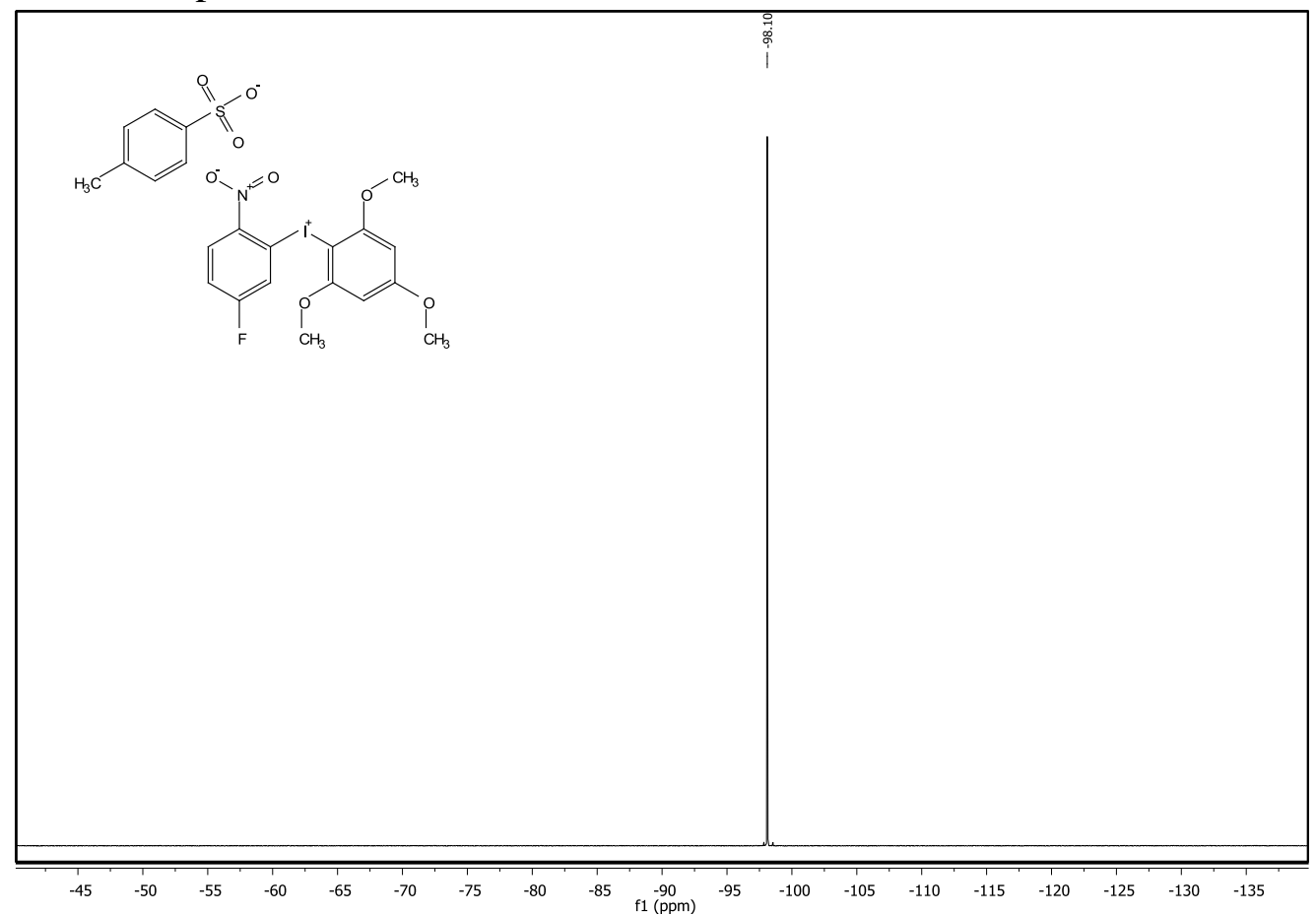


- ${ }^{1} \mathrm{H}$ NMR spectrum of $\mathbf{2 5}$ at $400 \mathrm{MHz}$ in DMSO- $d_{6}$ at $298 \mathrm{~K}$
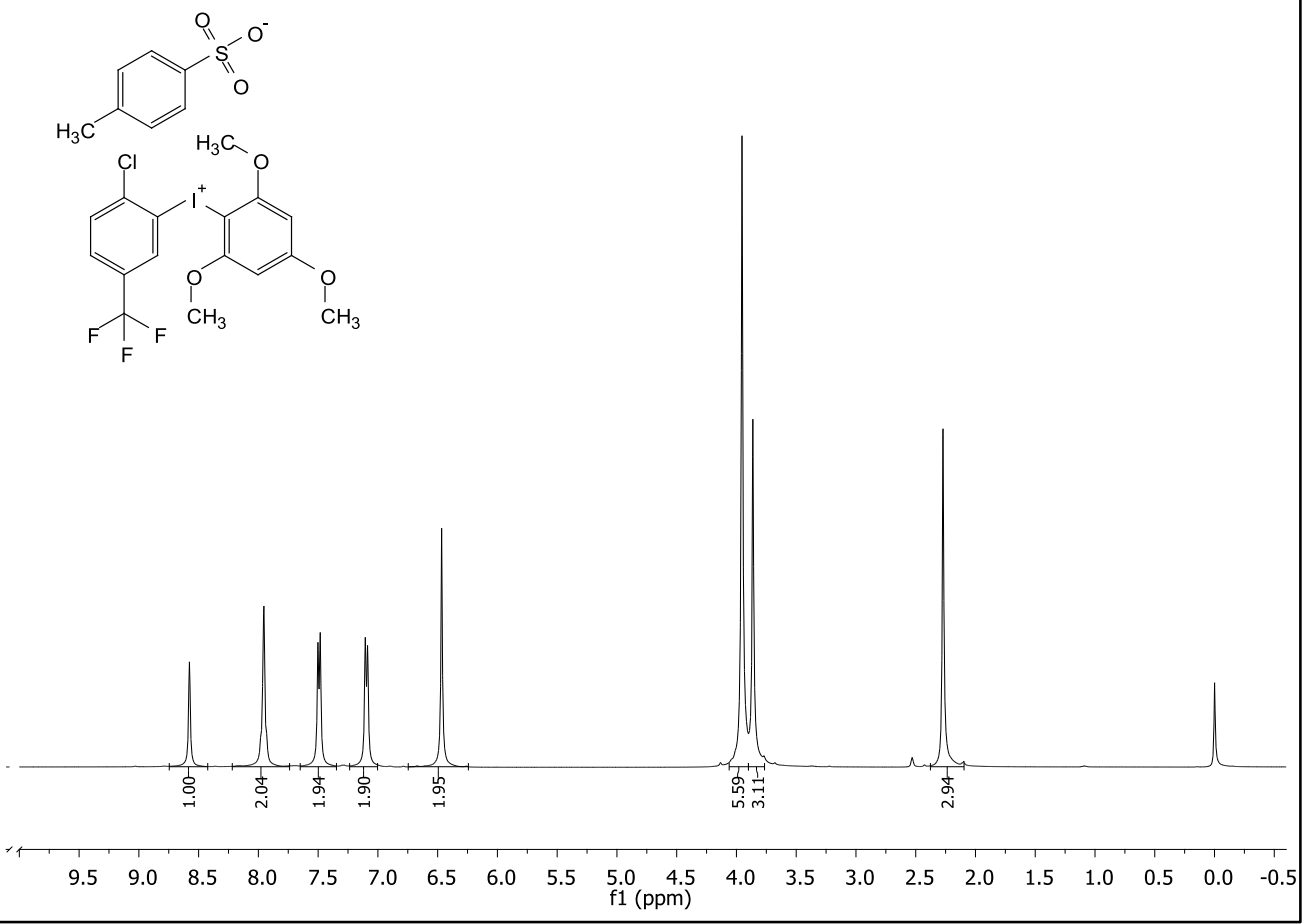

- ${ }^{13} \mathrm{C}$ NMR spectrum of 25 at $101 \mathrm{MHz}$ in DMSO- $d_{6}$ at $298 \mathrm{~K}$

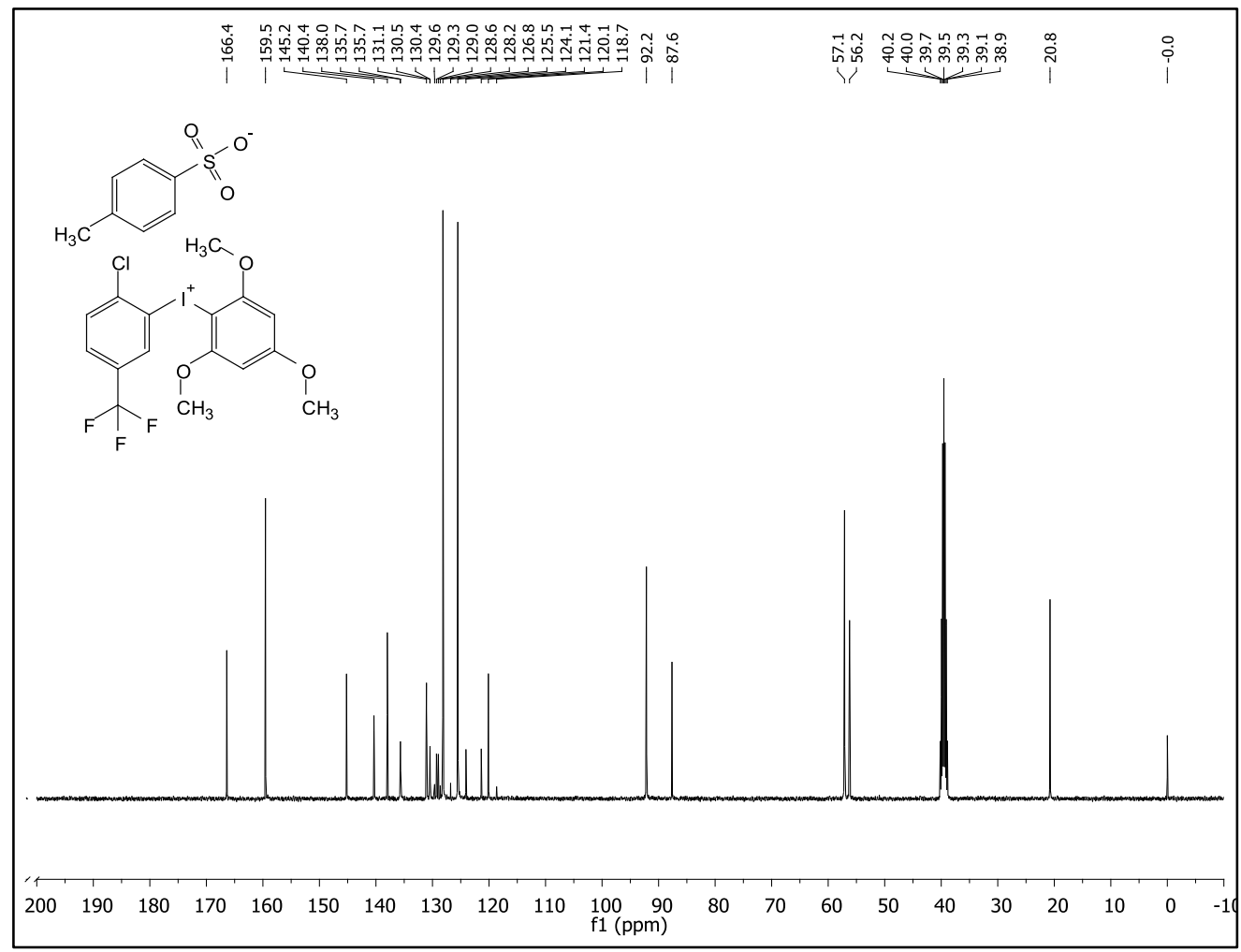


- ${ }^{19}$ F NMR spectrum of 25 at $376 \mathrm{MHz}$ in DMSO- $d_{6}$ at $298 \mathrm{~K}$

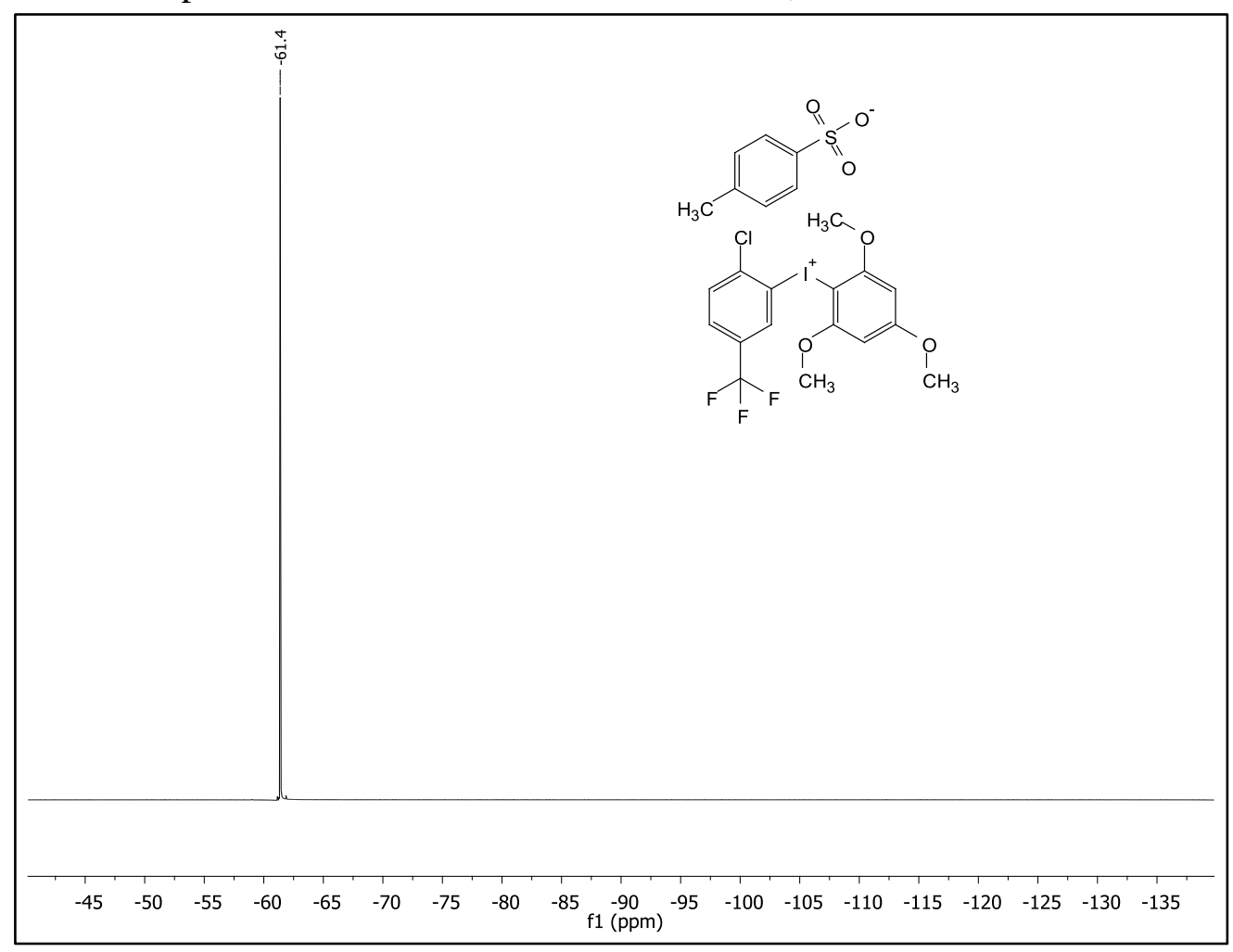

- ${ }^{1} \mathrm{H}$ NMR spectrum of $\mathbf{2 6}$ at $400 \mathrm{MHz}$ in DMSO- $d_{6}$ at $298 \mathrm{~K}$

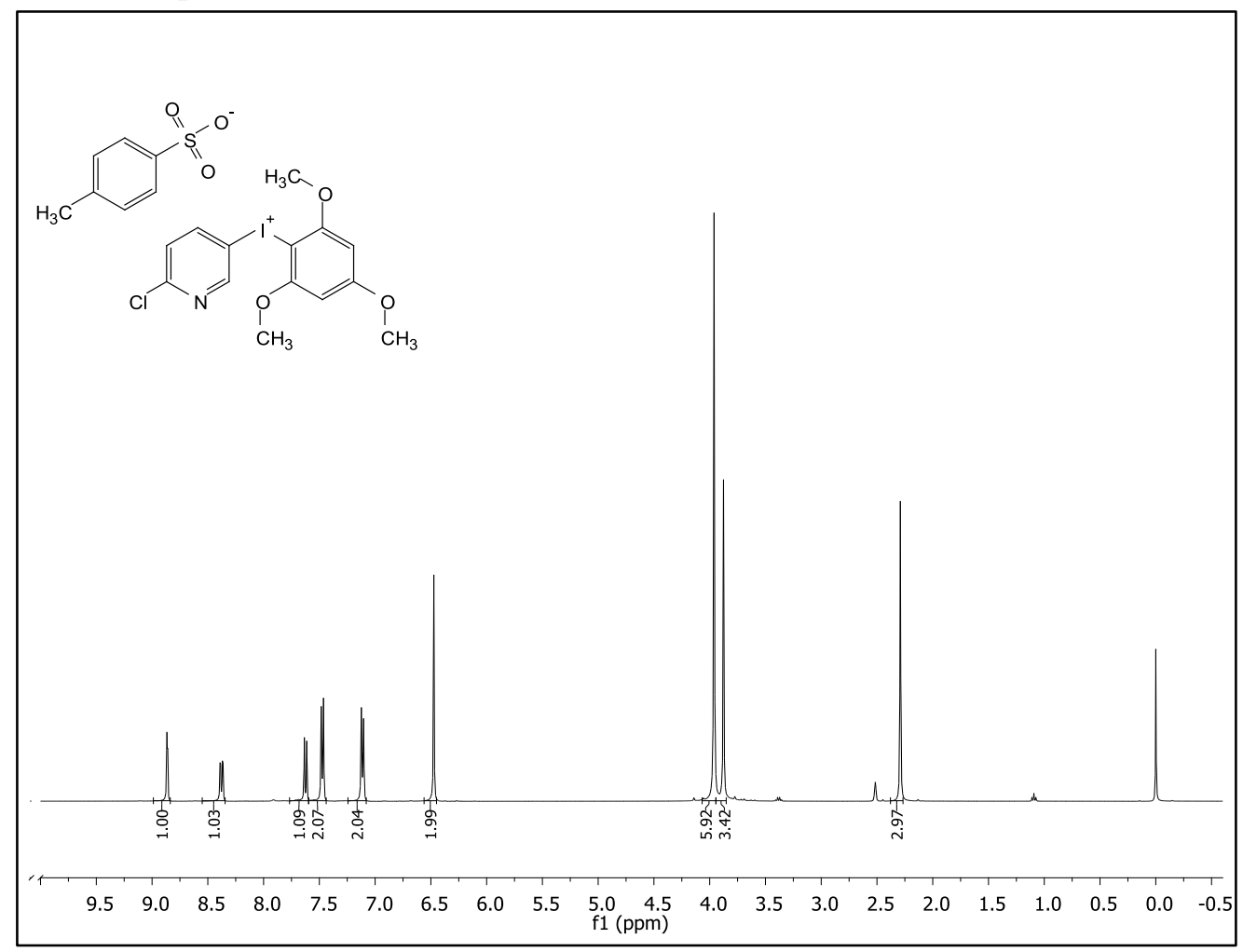


S39

- ${ }^{13} \mathrm{C}$ NMR spectrum of 26 at $101 \mathrm{MHz}$ in DMSO- $d_{6}$ at $298 \mathrm{~K}$

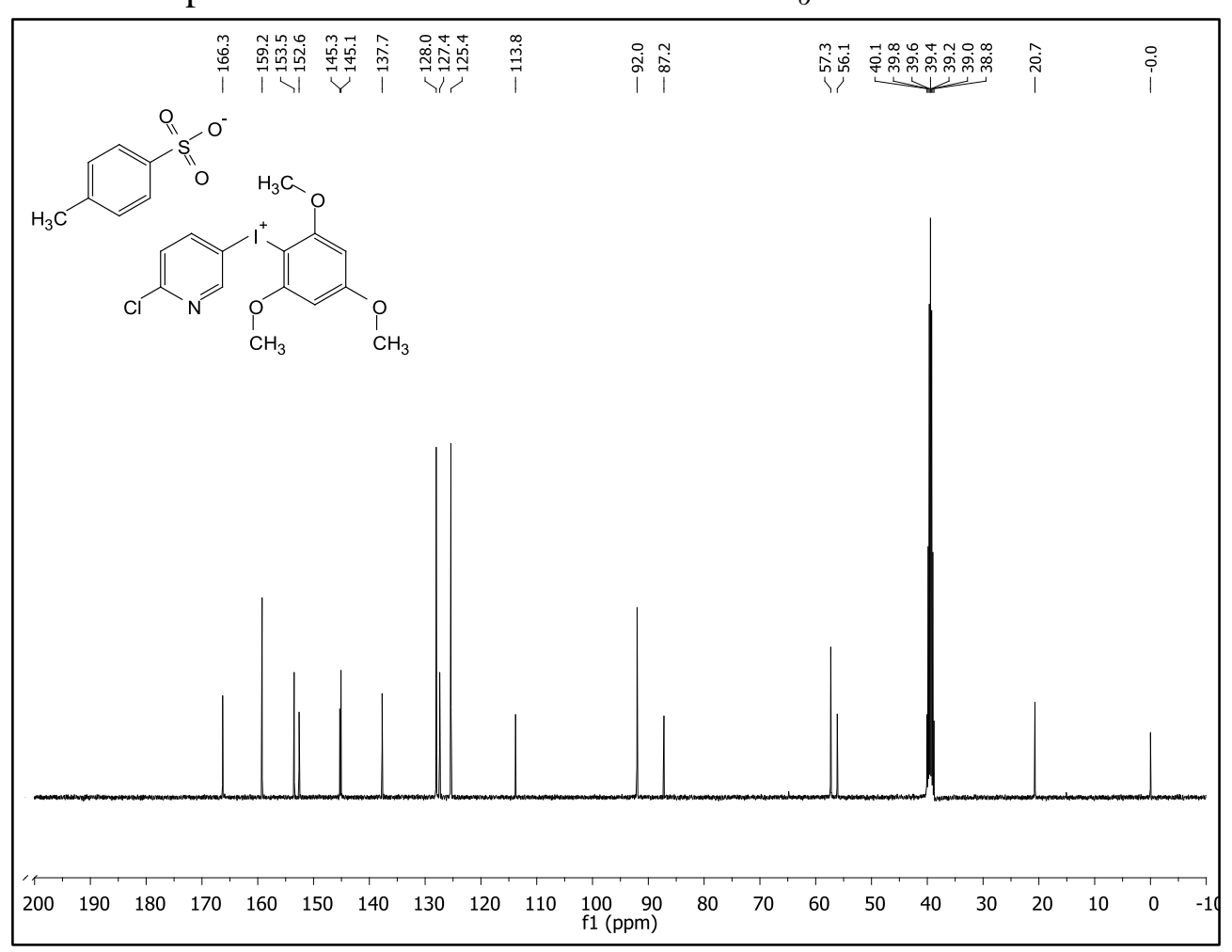

- ${ }^{1} \mathrm{H}$ NMR spectrum of 27 at $400 \mathrm{MHz}$ in DMSO- $d_{6}$ at $298 \mathrm{~K}$

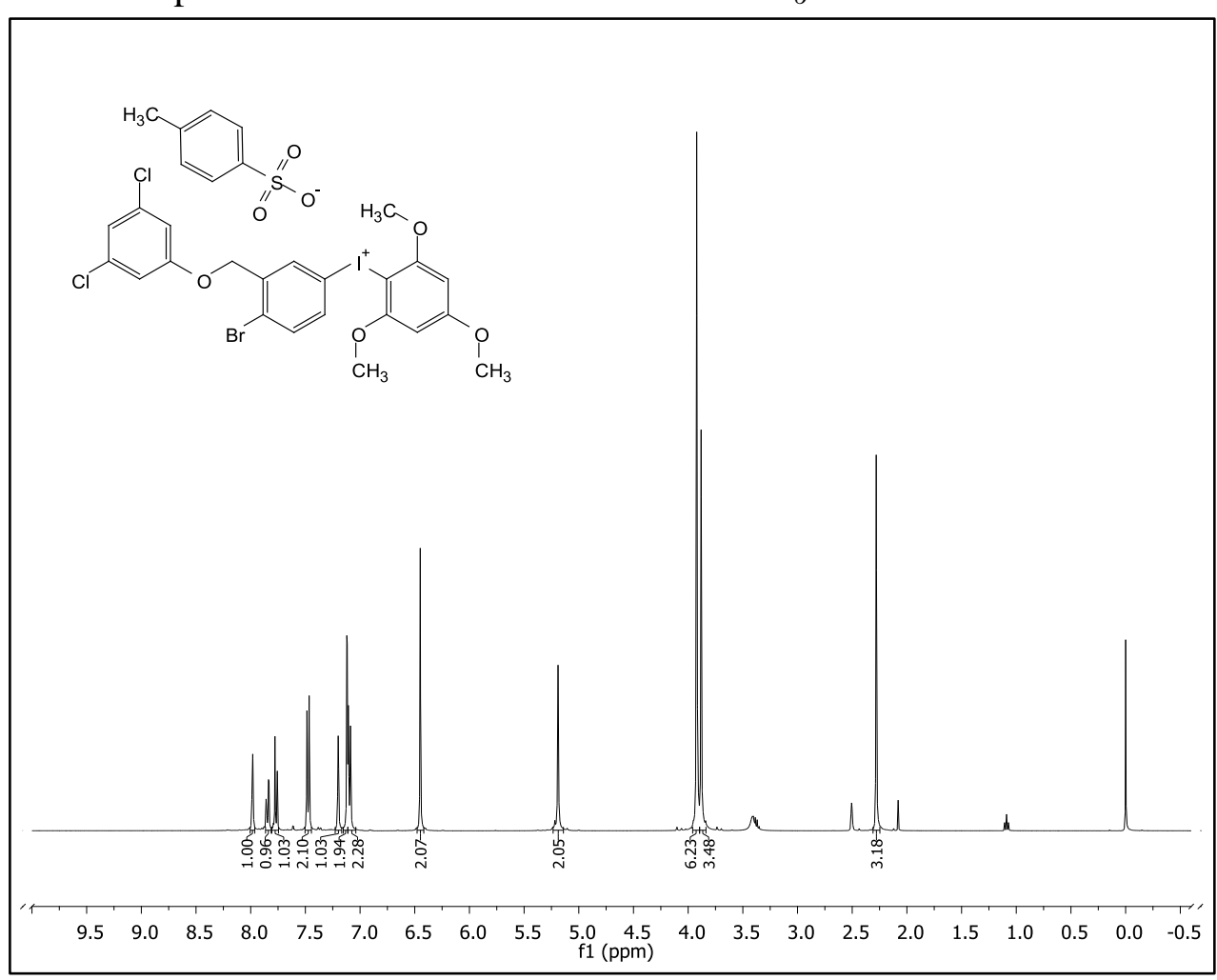


- ${ }^{13} \mathrm{C}$ NMR spectrum of 27 at $101 \mathrm{MHz}$ in DMSO- $d_{6}$ at $298 \mathrm{~K}$

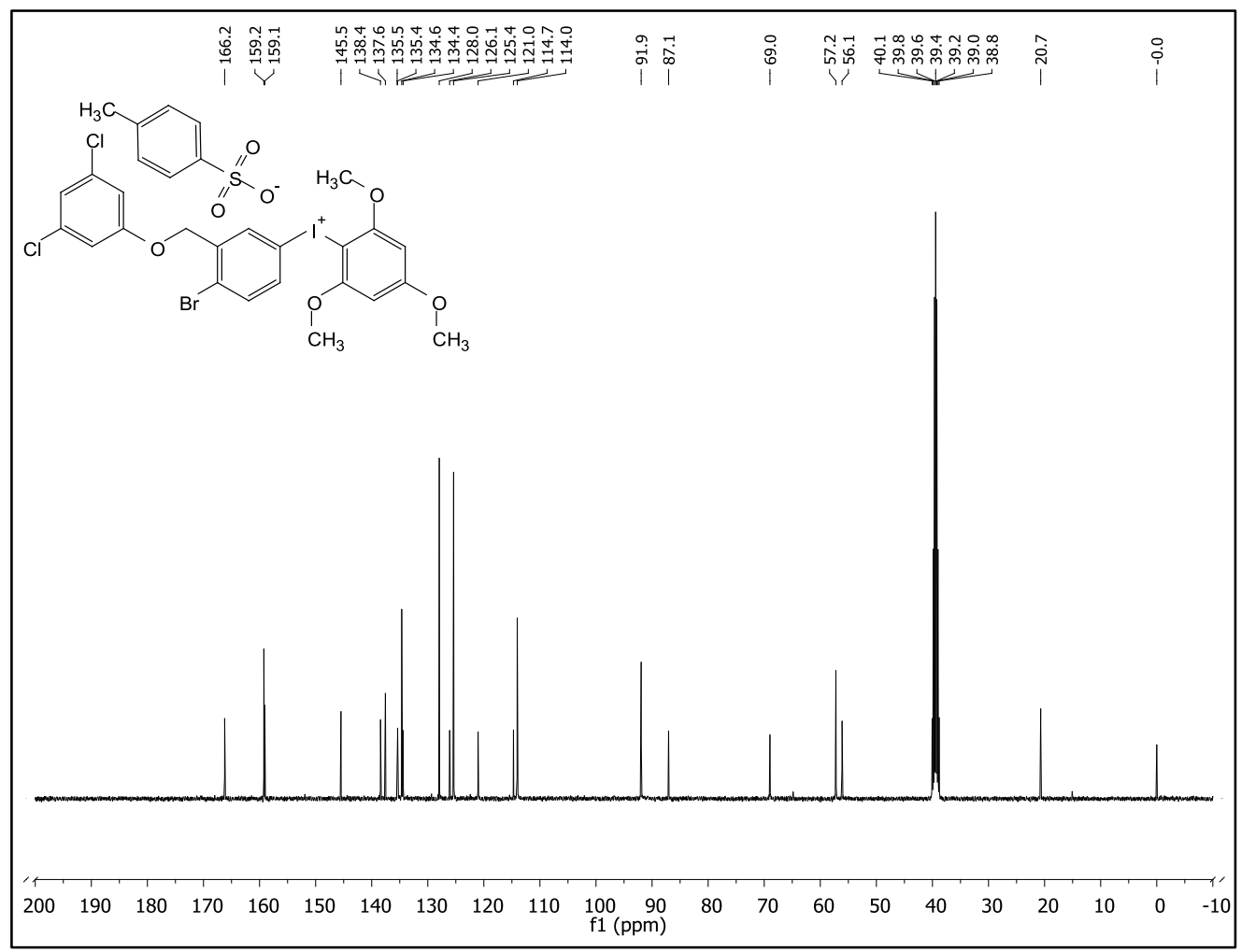

- ${ }^{1} \mathrm{H}$ NMR spectrum of $\mathbf{S 1}$ (precursor for 27 ) at $400 \mathrm{MHz}$ in $\mathrm{CDCl}_{3}$ at $298 \mathrm{~K}$

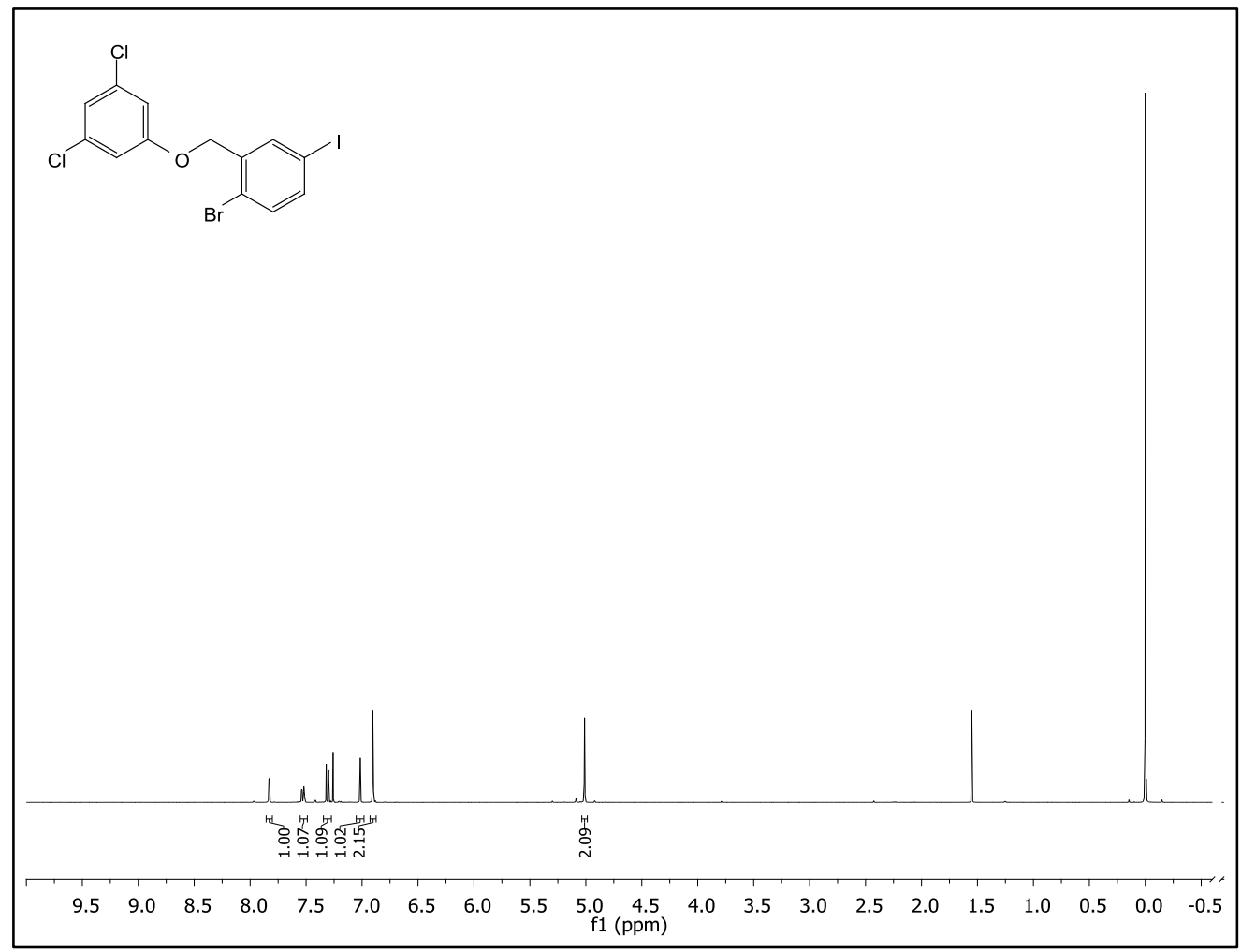


S41

- ${ }^{13} \mathrm{C}$ NMR spectrum of $\mathbf{S 1}$ (precursor for 27 ) at $101 \mathrm{MHz}$ in $\mathrm{CDCl}_{3}$ at $298 \mathrm{~K}$

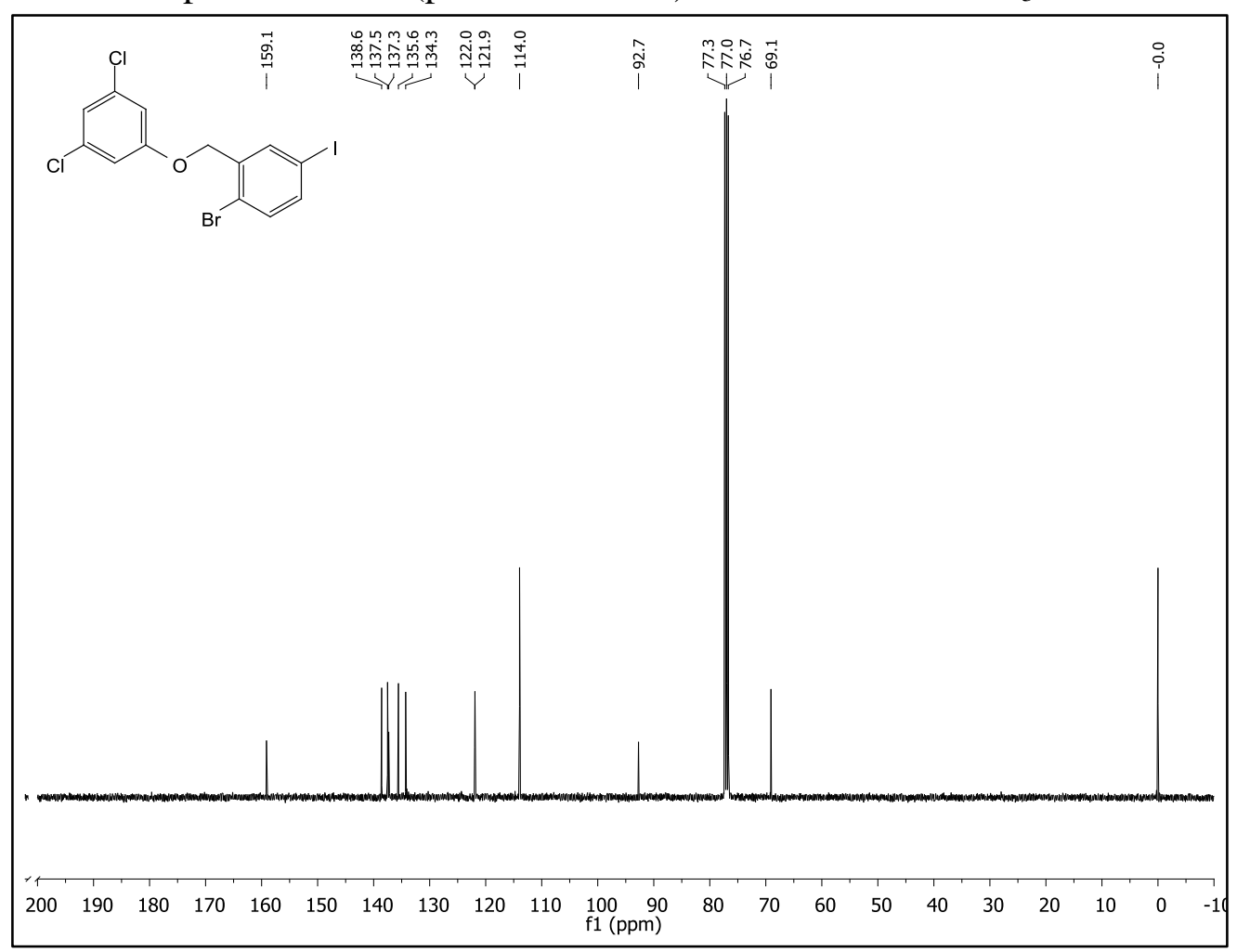

- $\quad{ }^{1} \mathrm{H}$ NMR spectrum of 28 at $400 \mathrm{MHz}$ in DMSO- $d_{6}$ at $298 \mathrm{~K}$

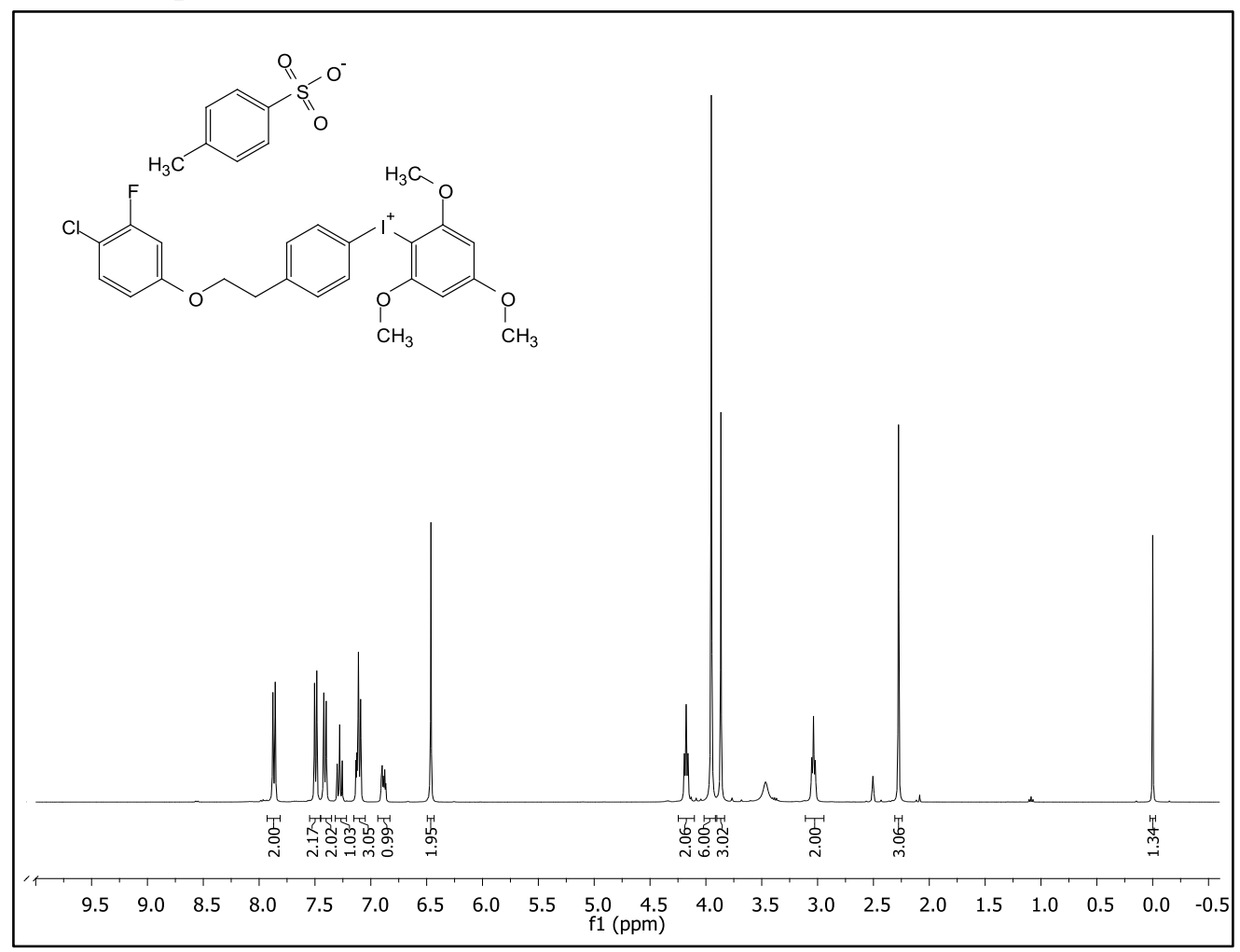


- ${ }^{13} \mathrm{C}$ NMR spectrum of 28 at $101 \mathrm{MHz}$ in DMSO- $d_{6}$ at $298 \mathrm{~K}$

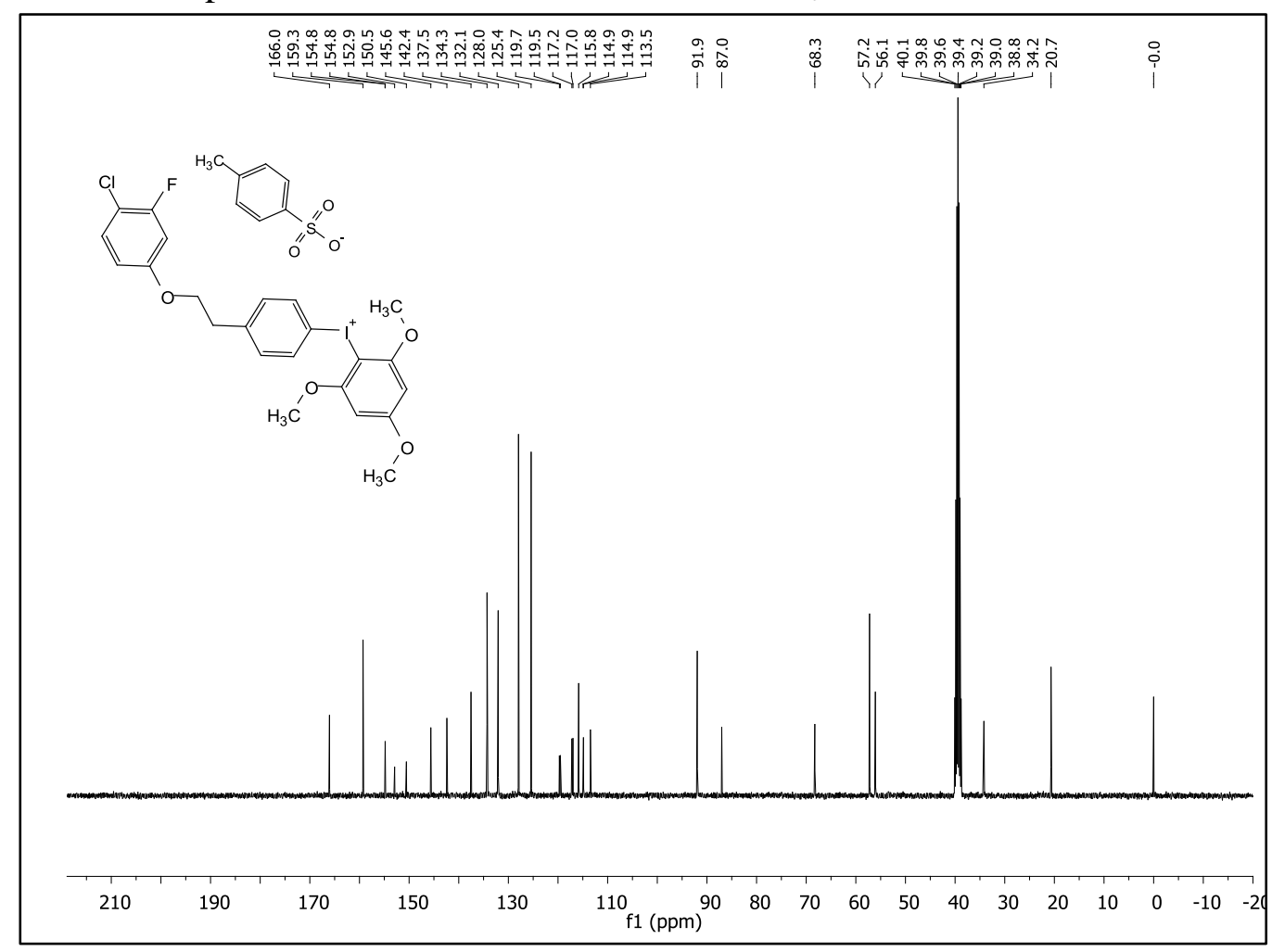

- ${ }^{19}$ F NMR spectrum of 28 at $376 \mathrm{MHz}$ in DMSO- $d_{6}$ at $298 \mathrm{~K}$

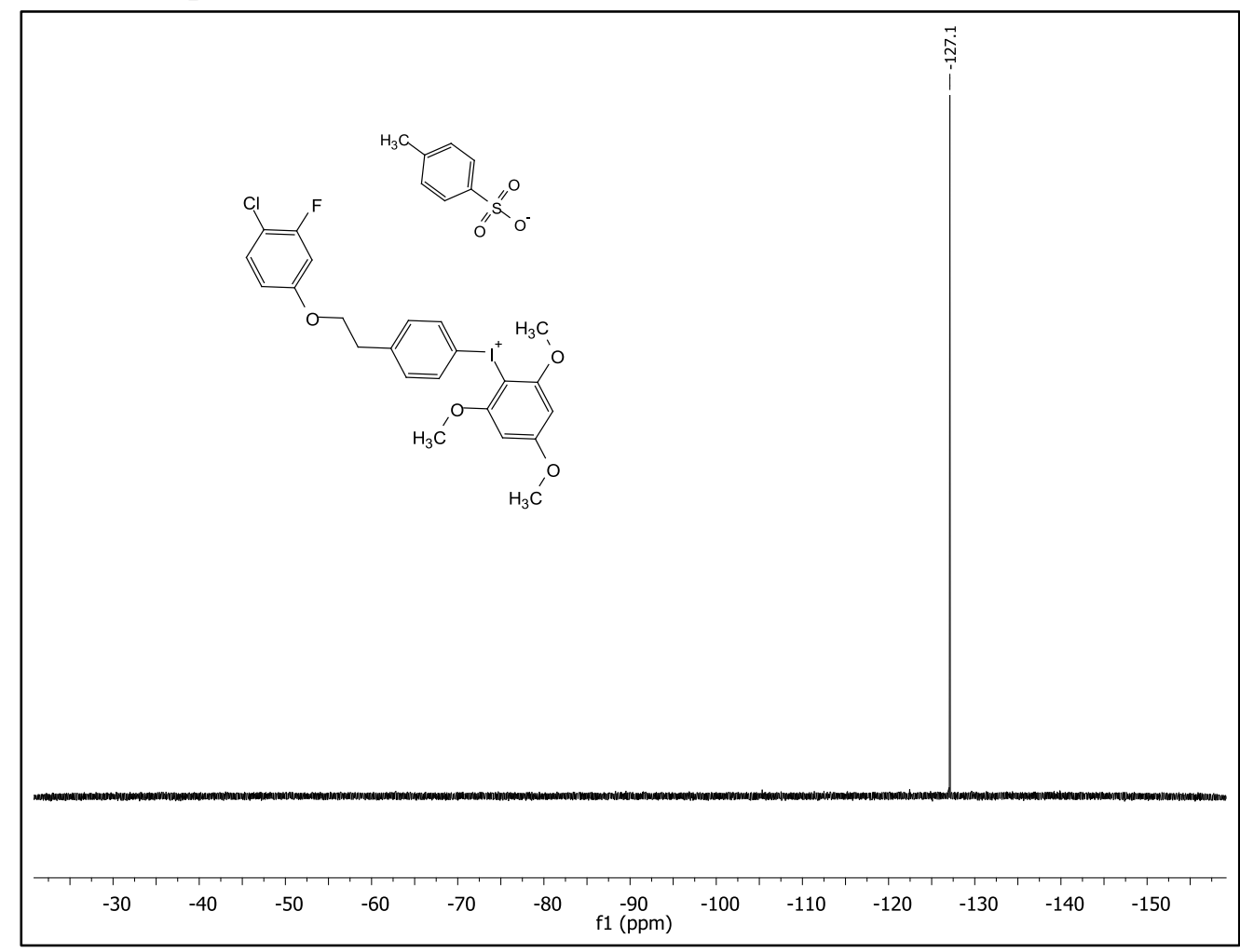


S43

- ${ }^{1} \mathrm{H}$ NMR spectrum of $\mathbf{S 2}$ (precursor of 28) at $400 \mathrm{MHz}$ in $\mathrm{CDCl}_{3}$ at $298 \mathrm{~K}$

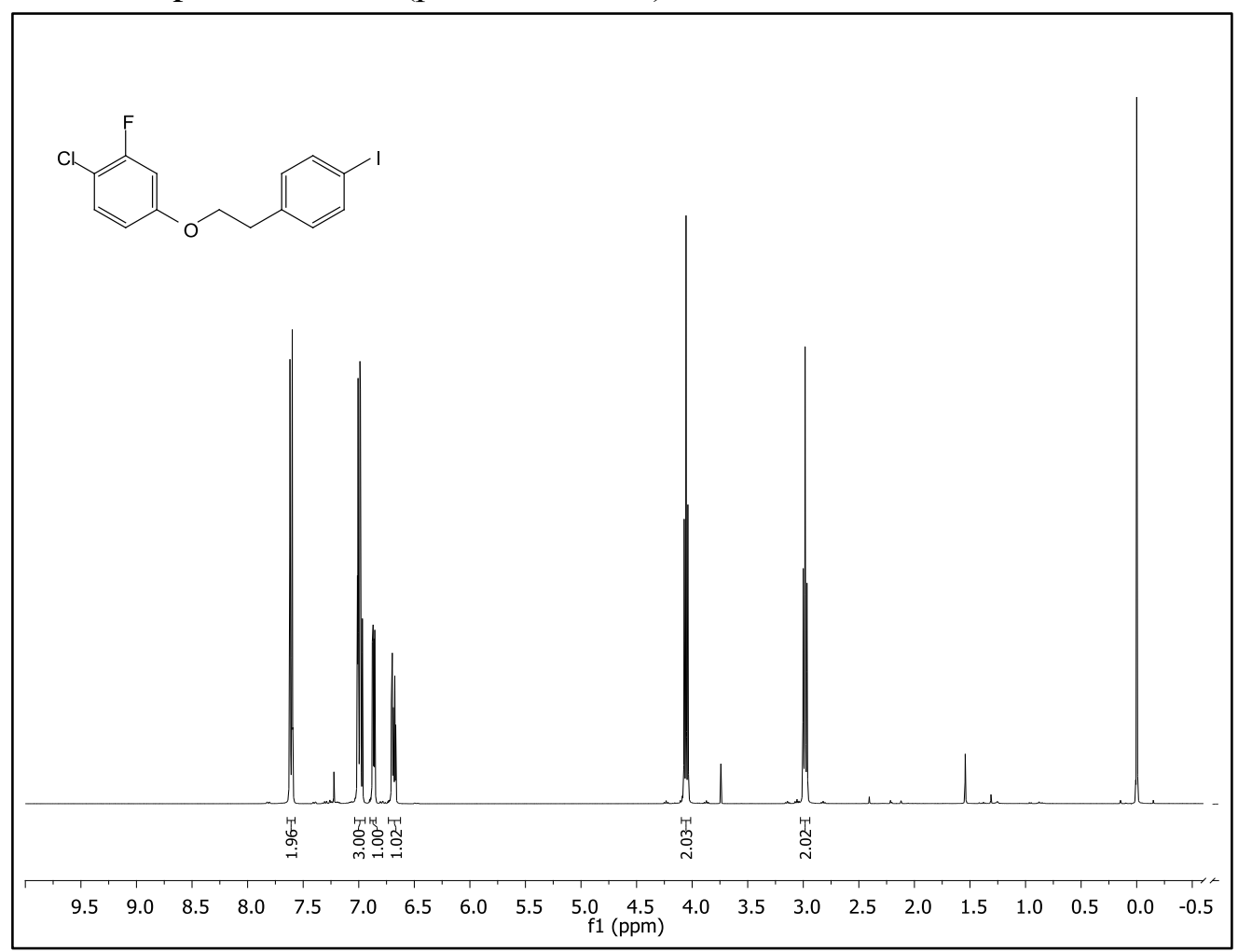

- ${ }^{13} \mathrm{C}$ NMR spectrum of $\mathbf{S 2}$ (precursor of 28) at $101 \mathrm{MHz}$ in $\mathrm{CDCl}_{3}$ at $298 \mathrm{~K}$

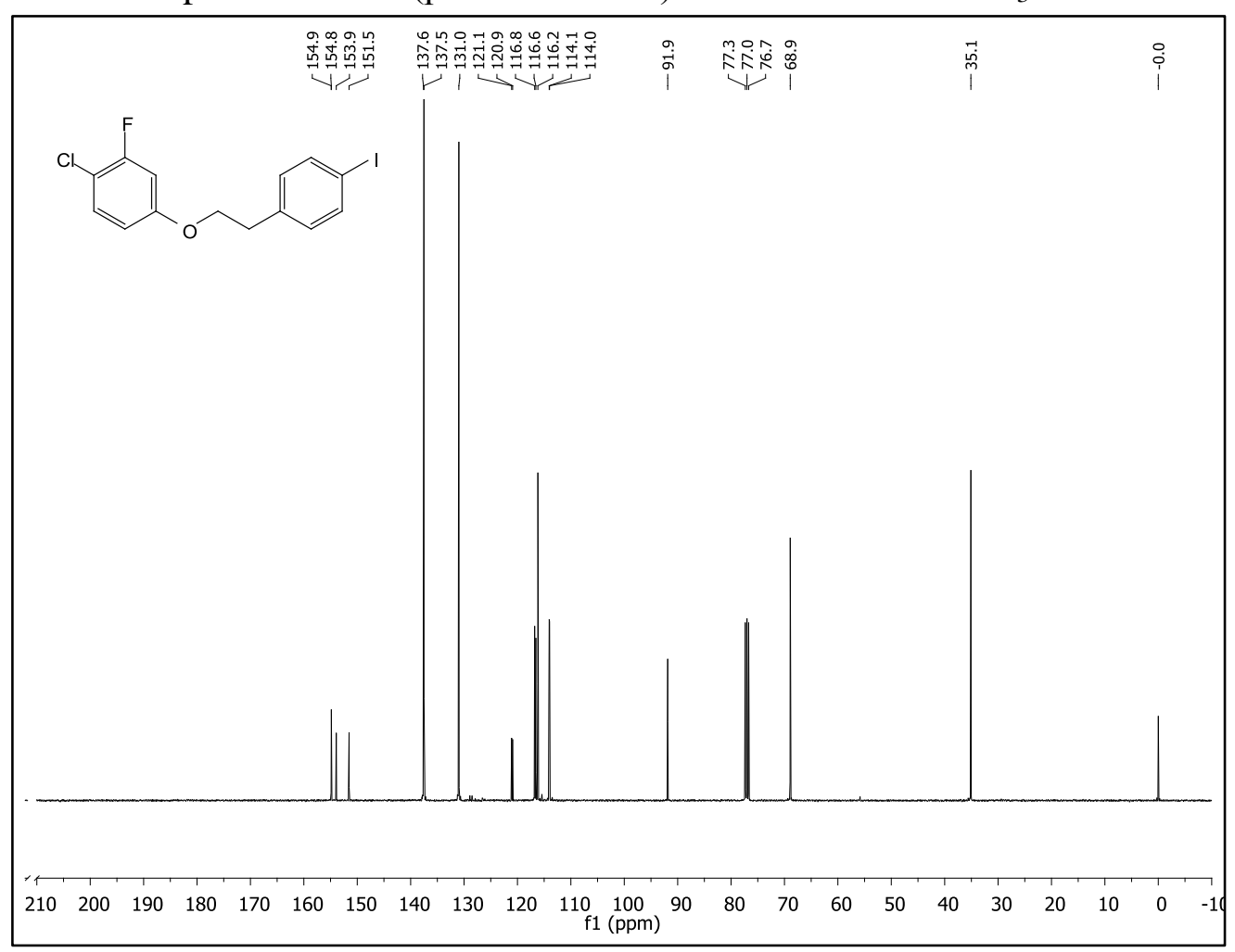


S44

- ${ }^{19} \mathrm{~F}$ NMR spectrum of $\mathbf{S 2}$ (precursor of 28) at $376 \mathrm{MHz}$ in $\mathrm{CDCl}_{3}$ at $298 \mathrm{~K}$

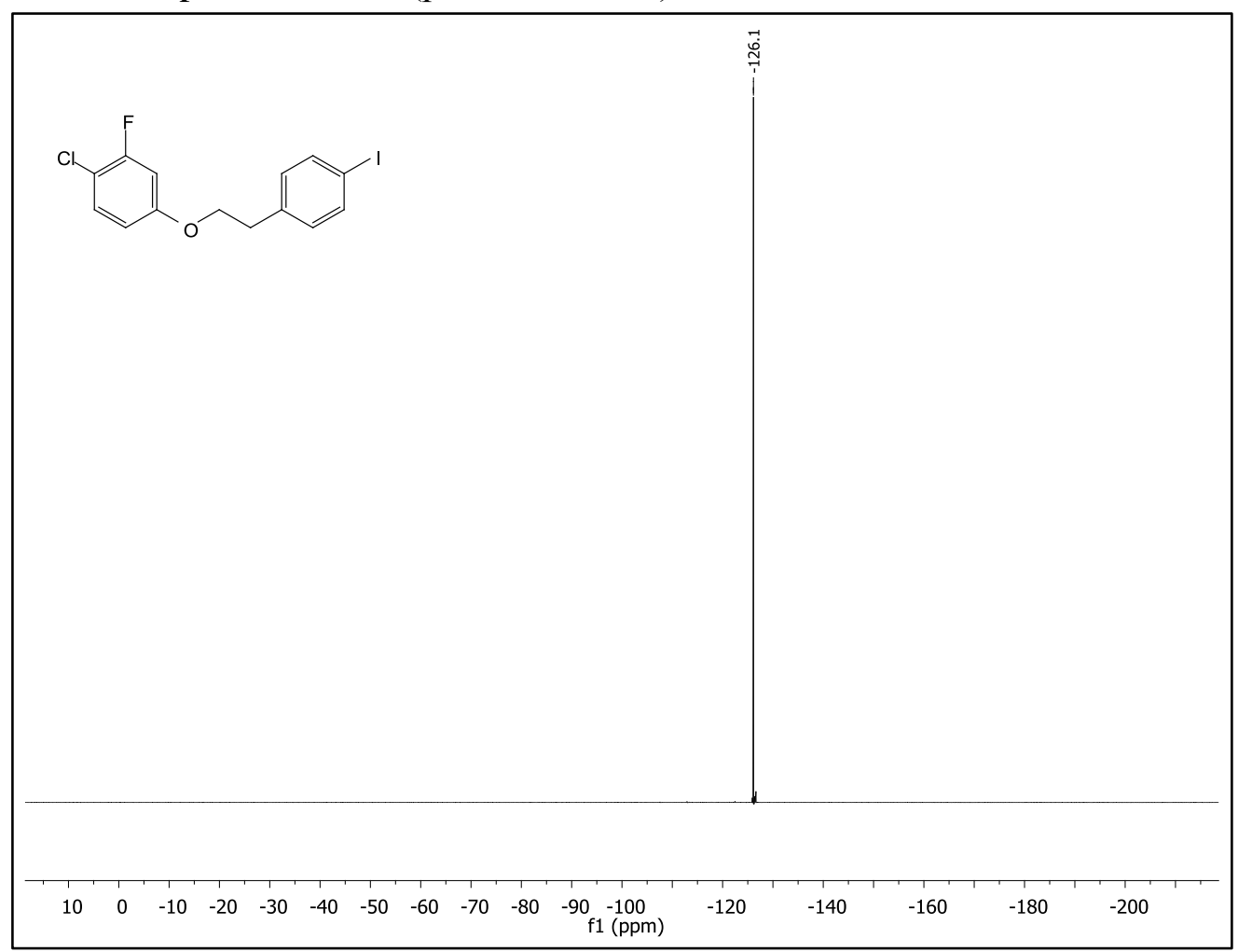

- ${ }^{1} \mathrm{H}$ NMR spectrum of 29 at $101 \mathrm{MHz}$ in DMSO- $d_{6}$ at $298 \mathrm{~K}$

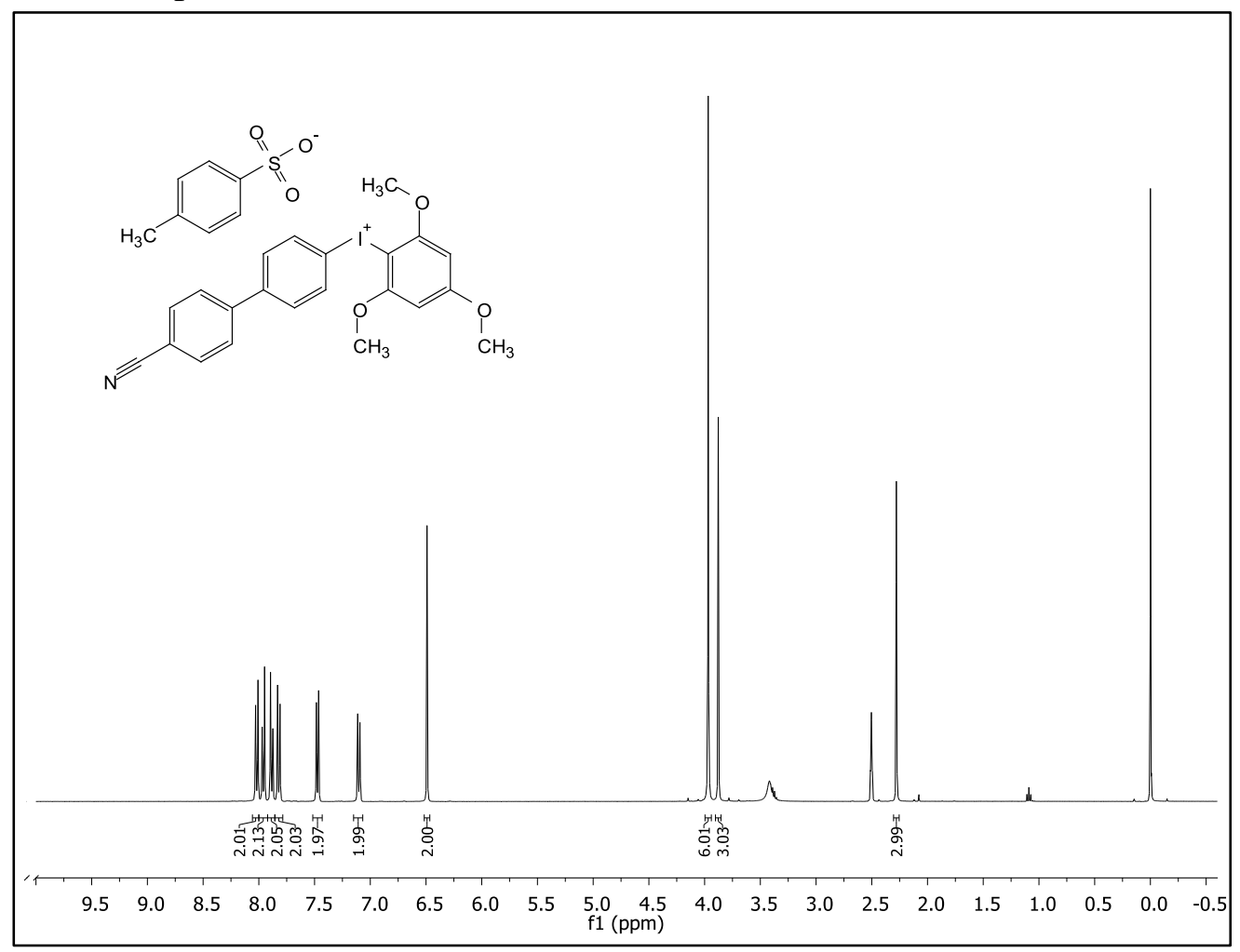


- ${ }^{13} \mathrm{C}$ NMR spectrum of 29 at $101 \mathrm{MHz}$ in DMSO- $d_{6}$ at $298 \mathrm{~K}$

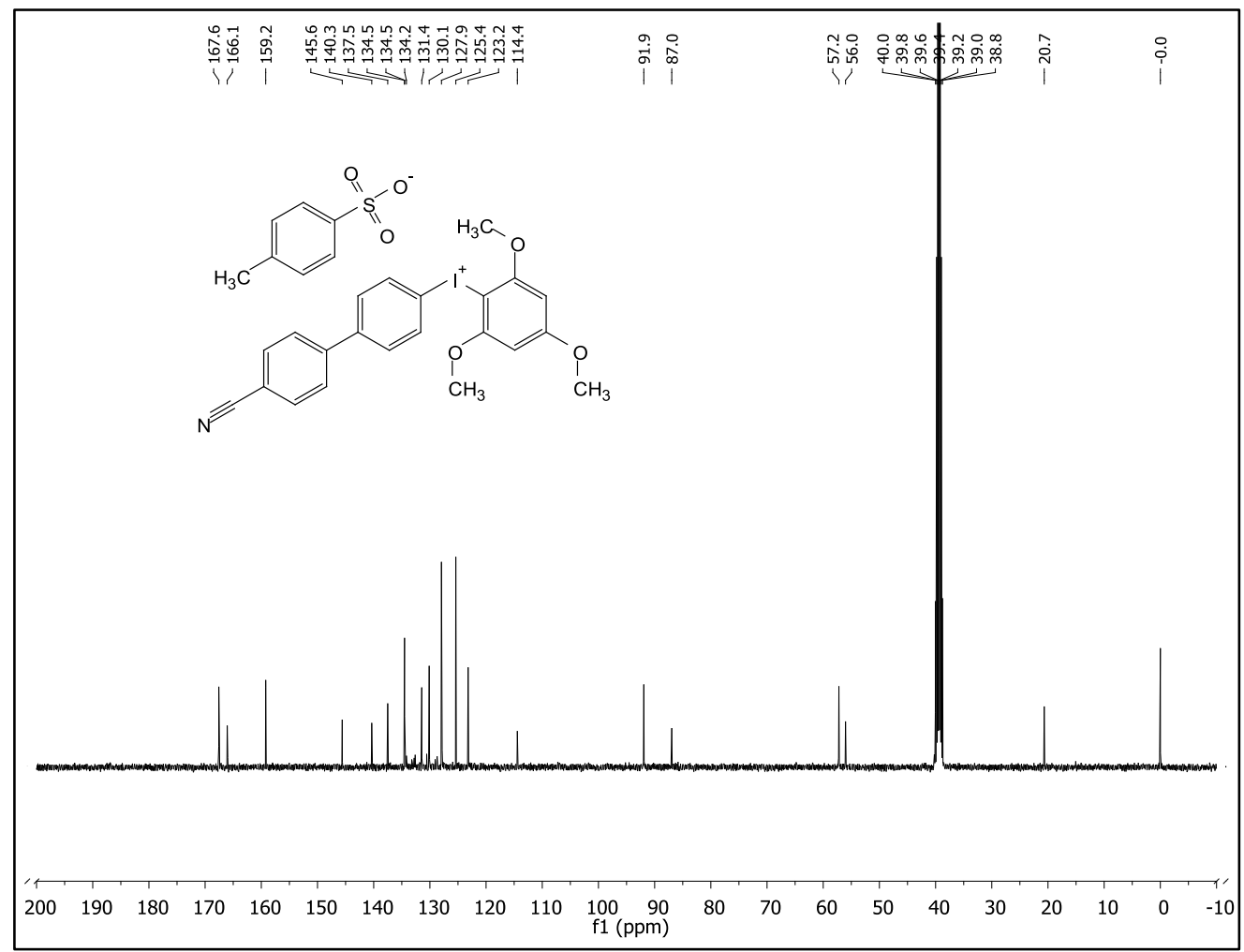

- ${ }^{1} \mathrm{H}$ NMR spectrum of $\mathbf{1 4 - B r}$ at $400 \mathrm{MHz}$ in DMSO- $d_{6}$ at $298 \mathrm{~K}$
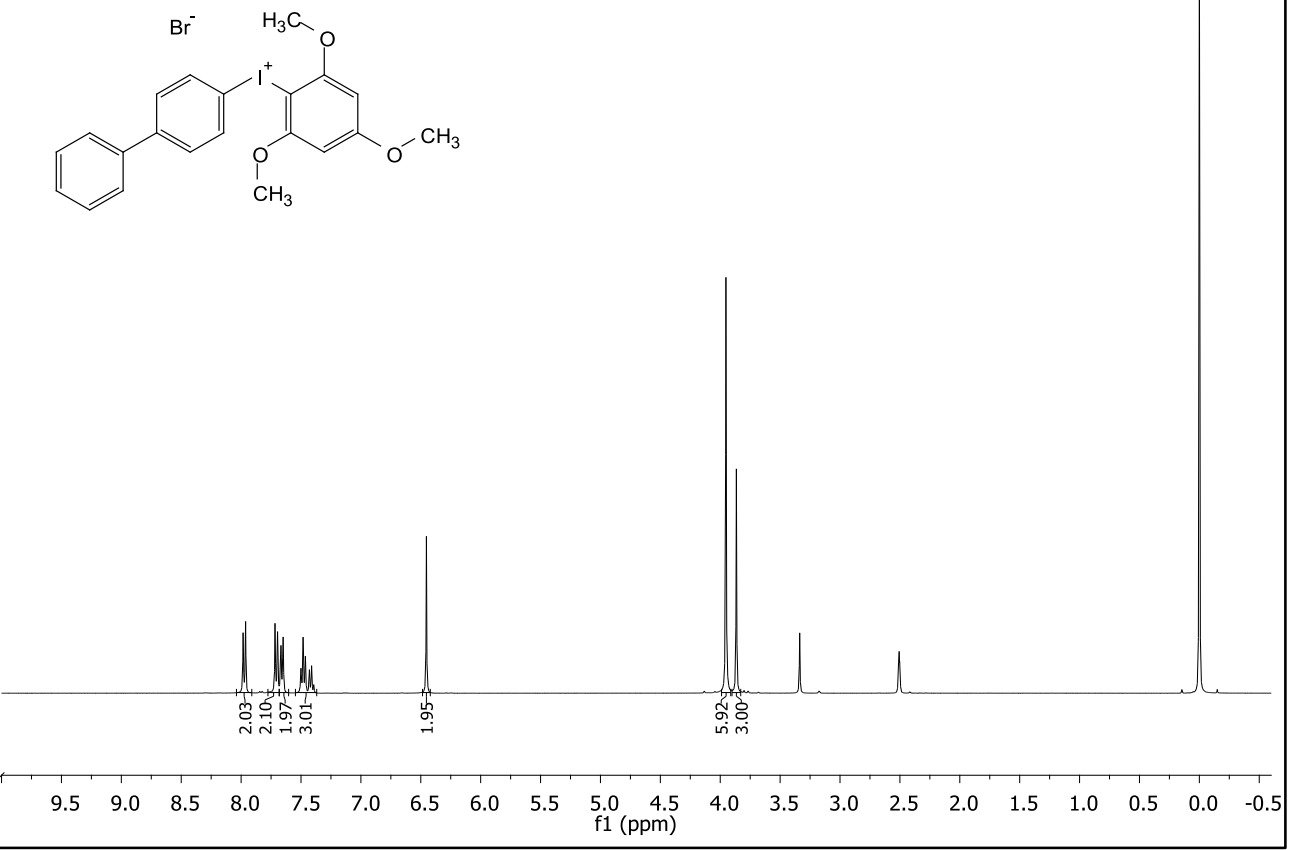
S46

- ${ }^{13} \mathrm{C}$ NMR spectrum of $\mathbf{1 4 - B r}$ at $101 \mathrm{MHz}$ in DMSO- $d_{6}$ at $298 \mathrm{~K}$

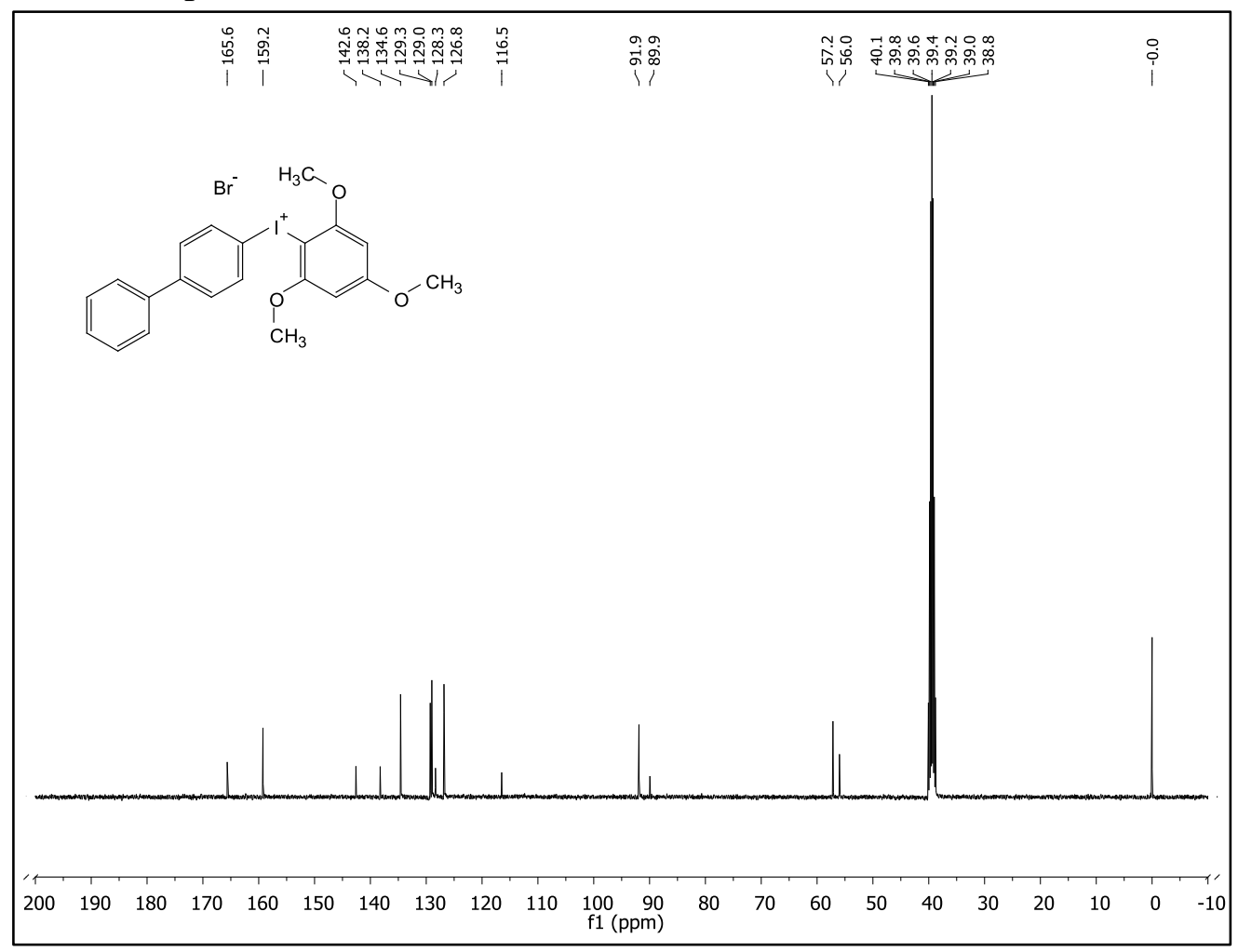

- ${ }^{1} \mathrm{H}$ NMR spectrum of 14-I at $400 \mathrm{MHz}$ in DMSO- $d_{6}$ at $298 \mathrm{~K}$

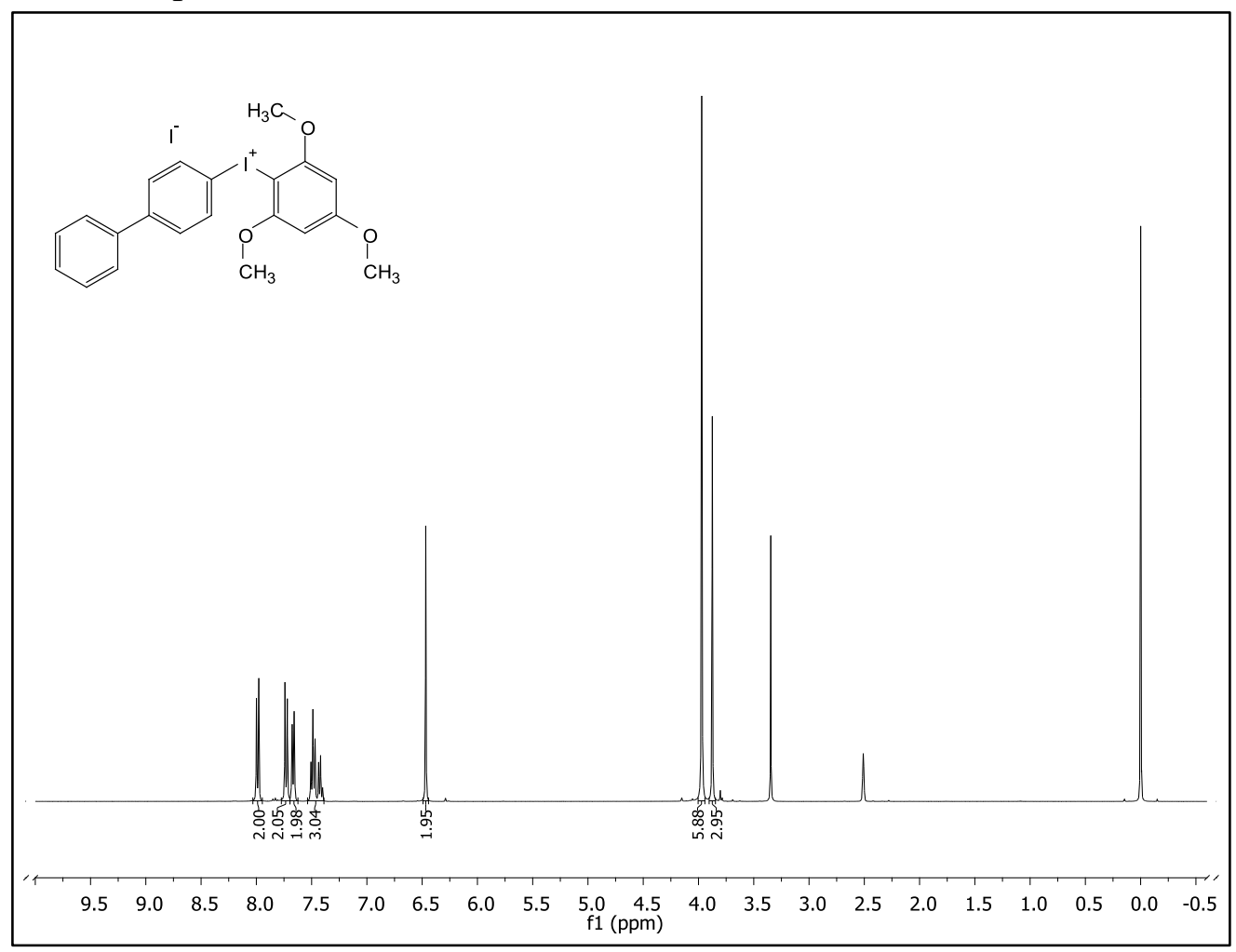


- ${ }^{13} \mathrm{C}$ NMR spectrum of 14-I at $101 \mathrm{MHz}$ in DMSO- $d_{6}$ at $298 \mathrm{~K}$

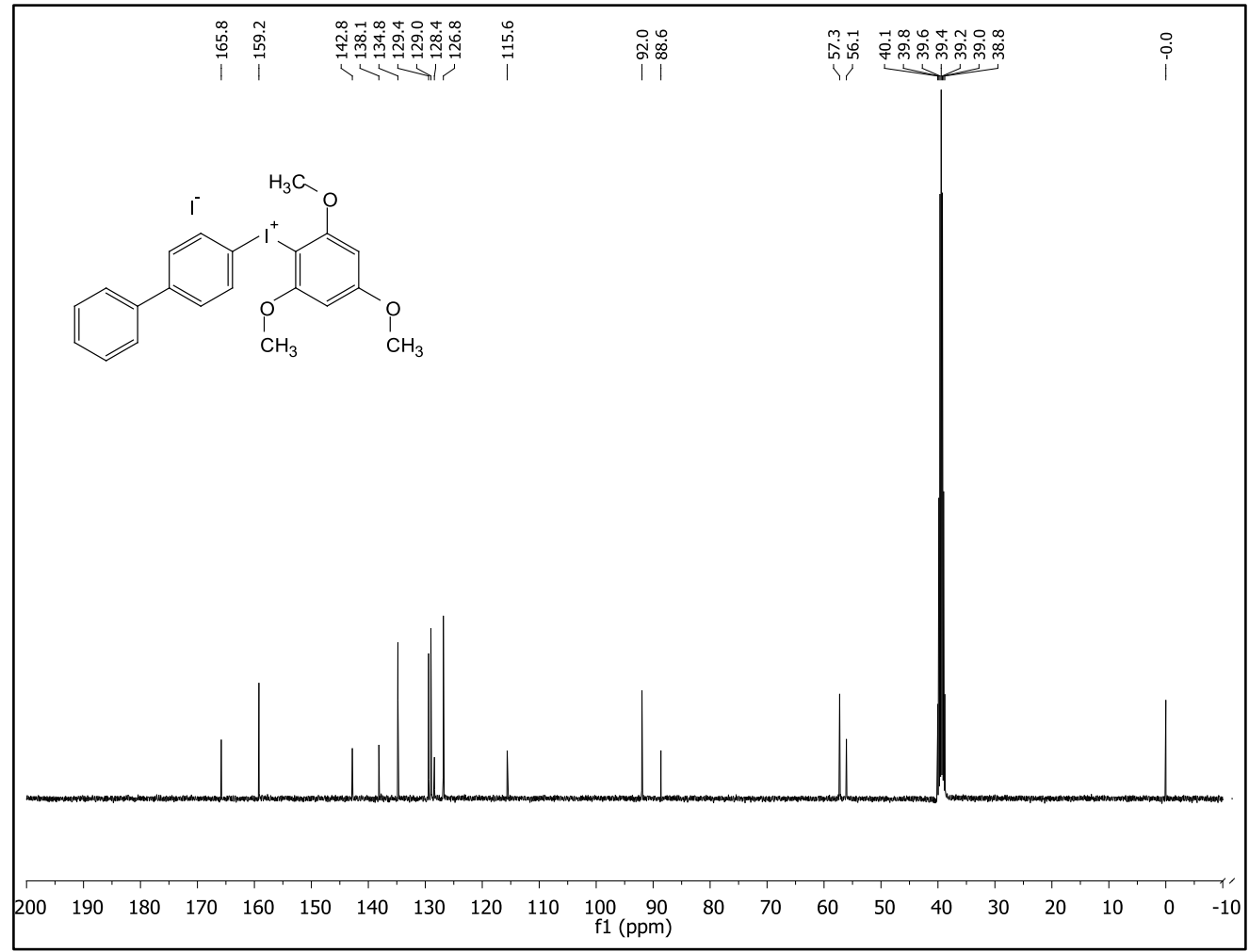

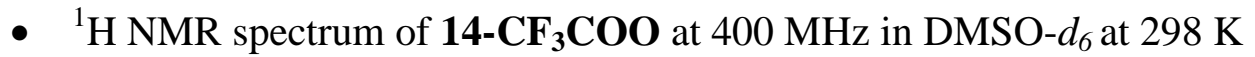

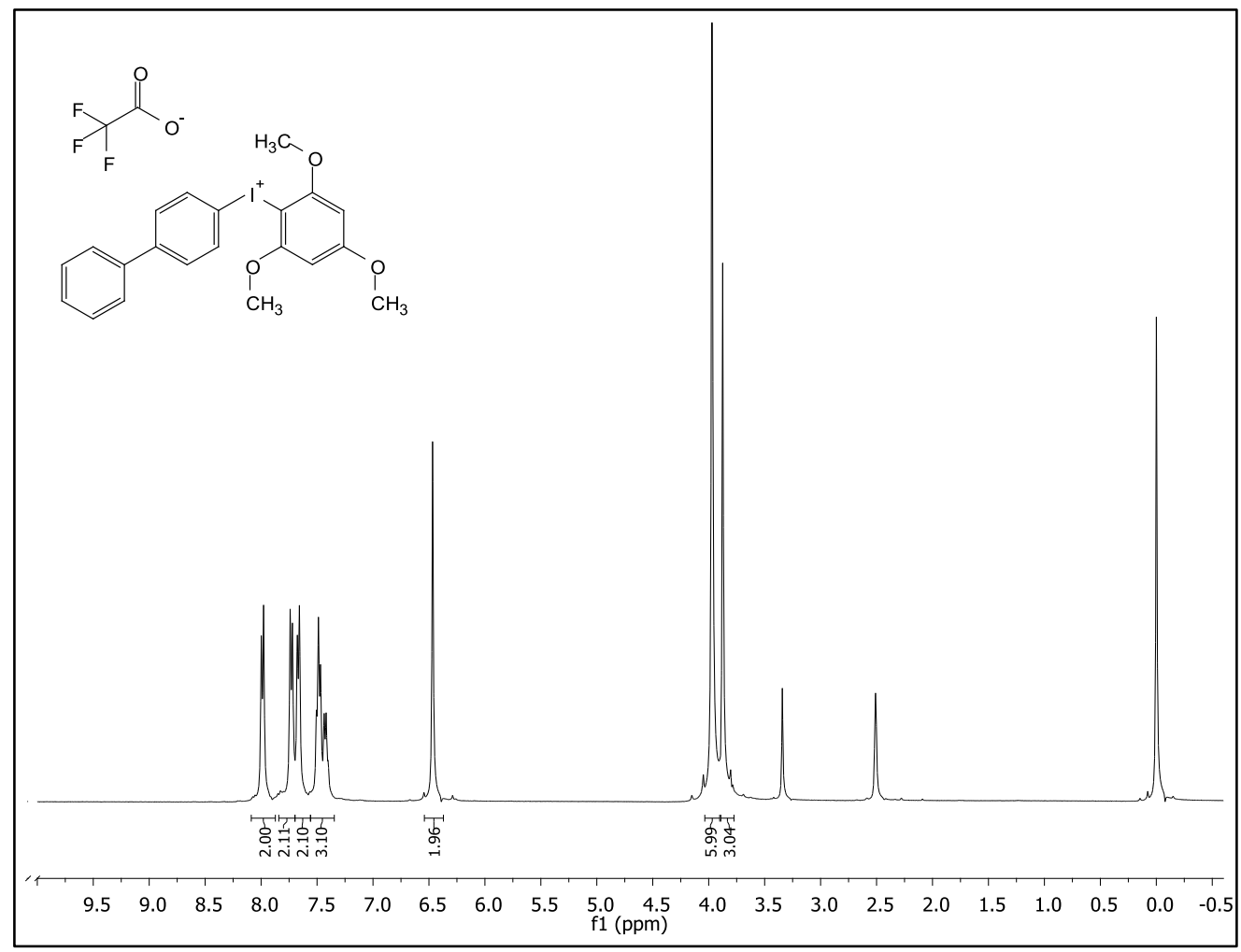




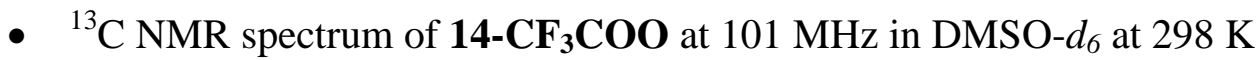

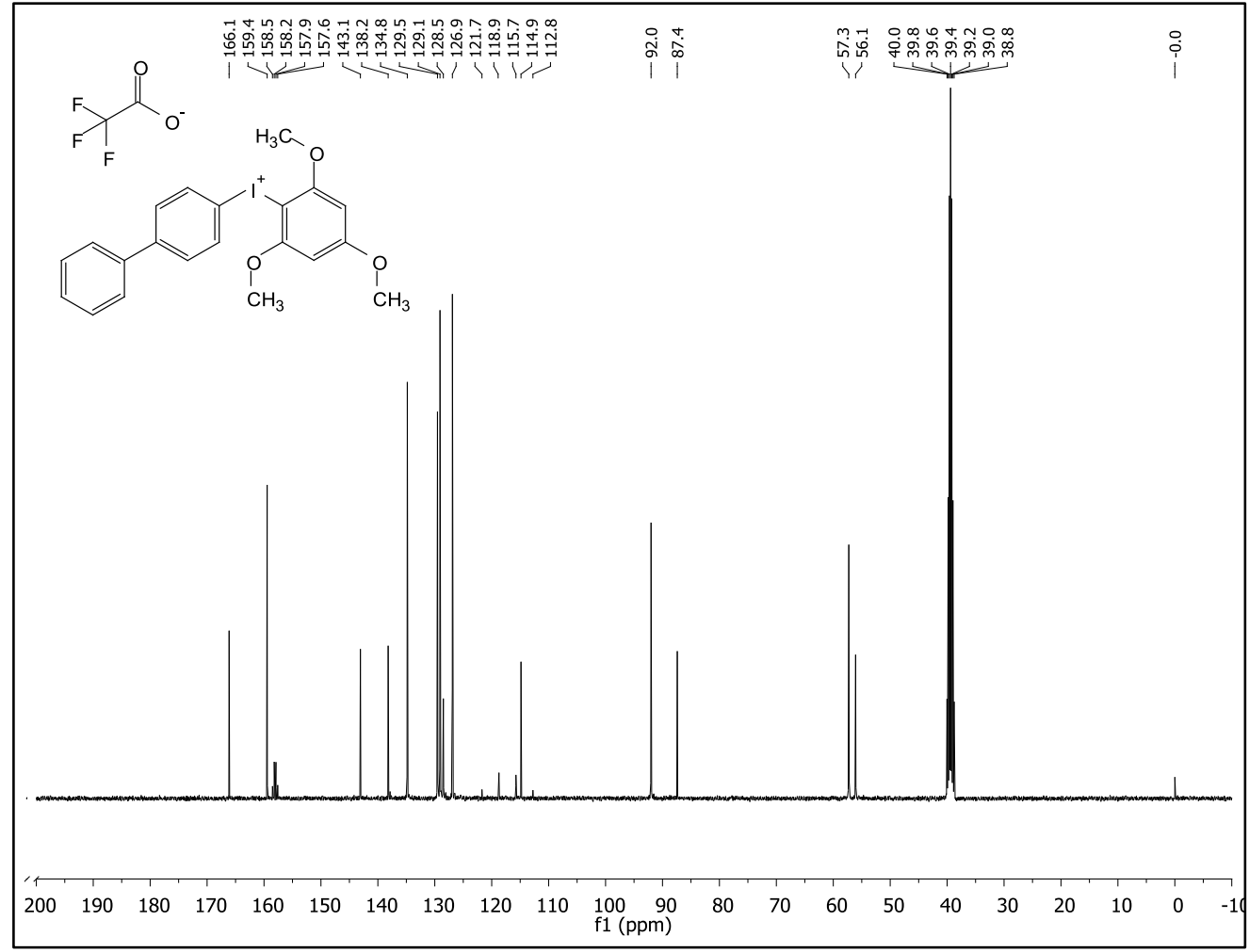

- ${ }^{19} \mathrm{~F}$ NMR spectrum of $\mathbf{1 4 -} \mathbf{C F}_{\mathbf{3}} \mathbf{C O O}$ at $376 \mathrm{MHz}$ in DMSO- $d_{6}$ at $298 \mathrm{~K}$

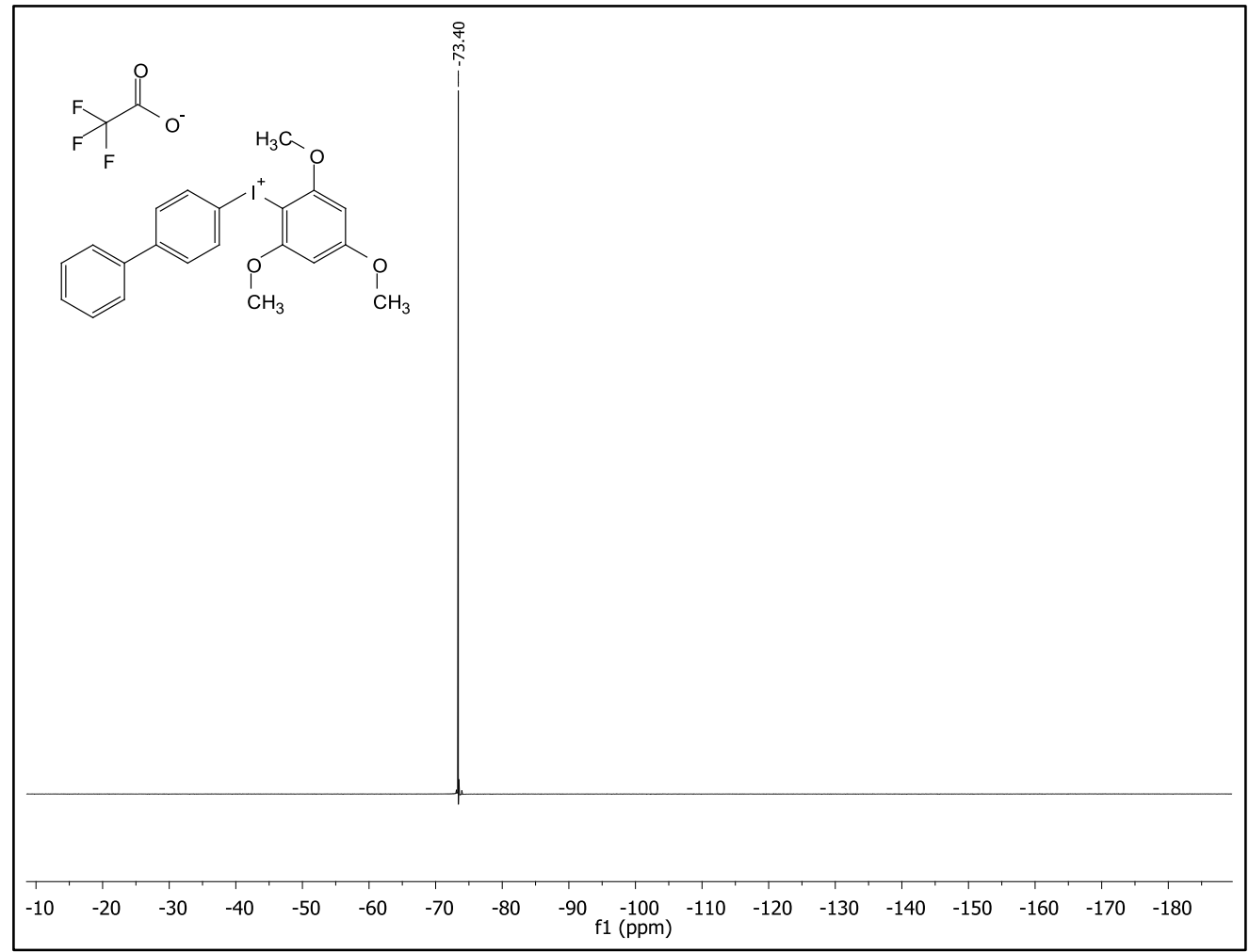


S49

- ${ }^{1} \mathrm{H}$ NMR spectrum of 14-OTf at $400 \mathrm{MHz}$ in DMSO- $d_{6}$ at $298 \mathrm{~K}$

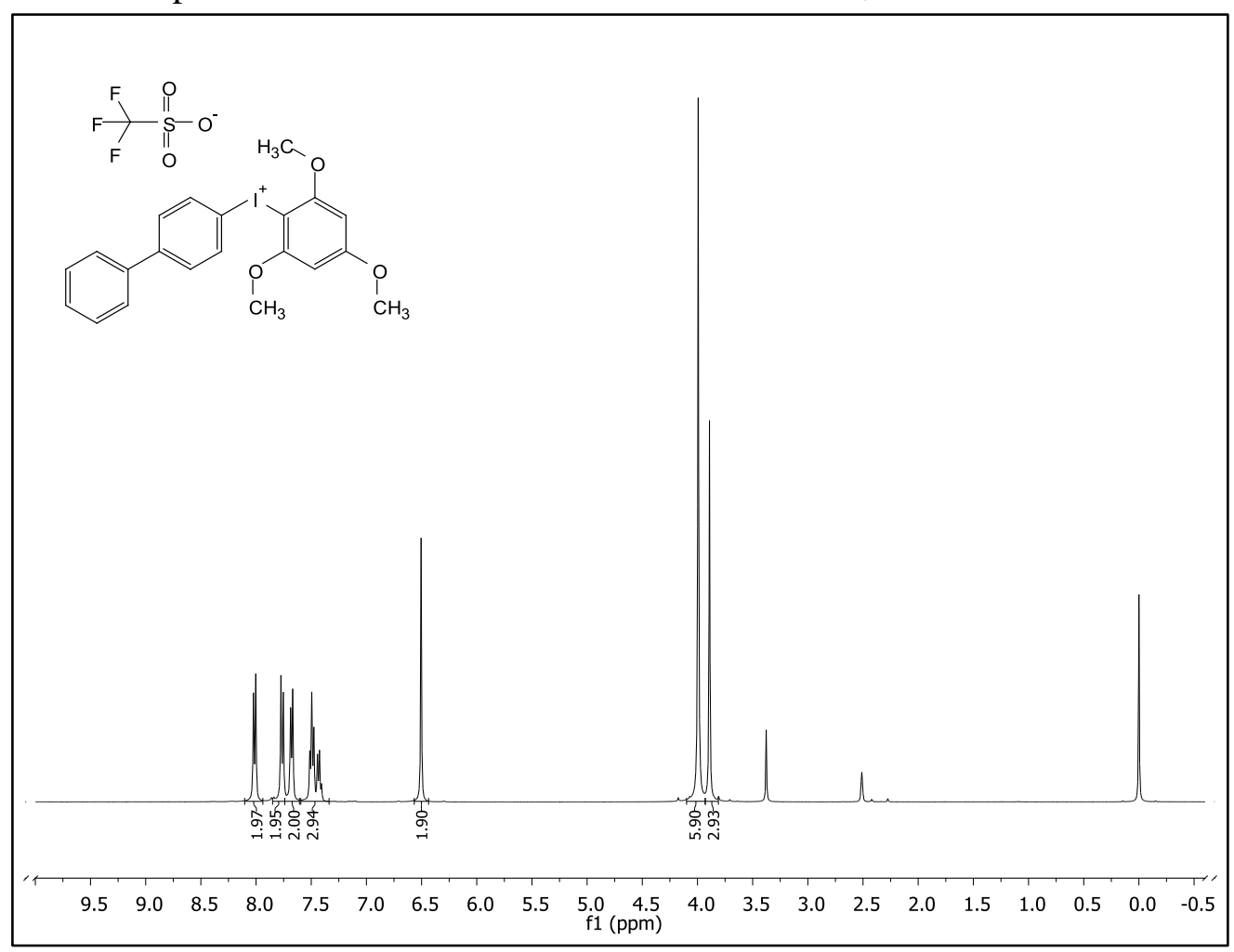

- ${ }^{13} \mathrm{C}$ NMR spectrum of 14-OTf at $101 \mathrm{MHz}$ in DMSO- $d_{6}$ at $298 \mathrm{~K}$

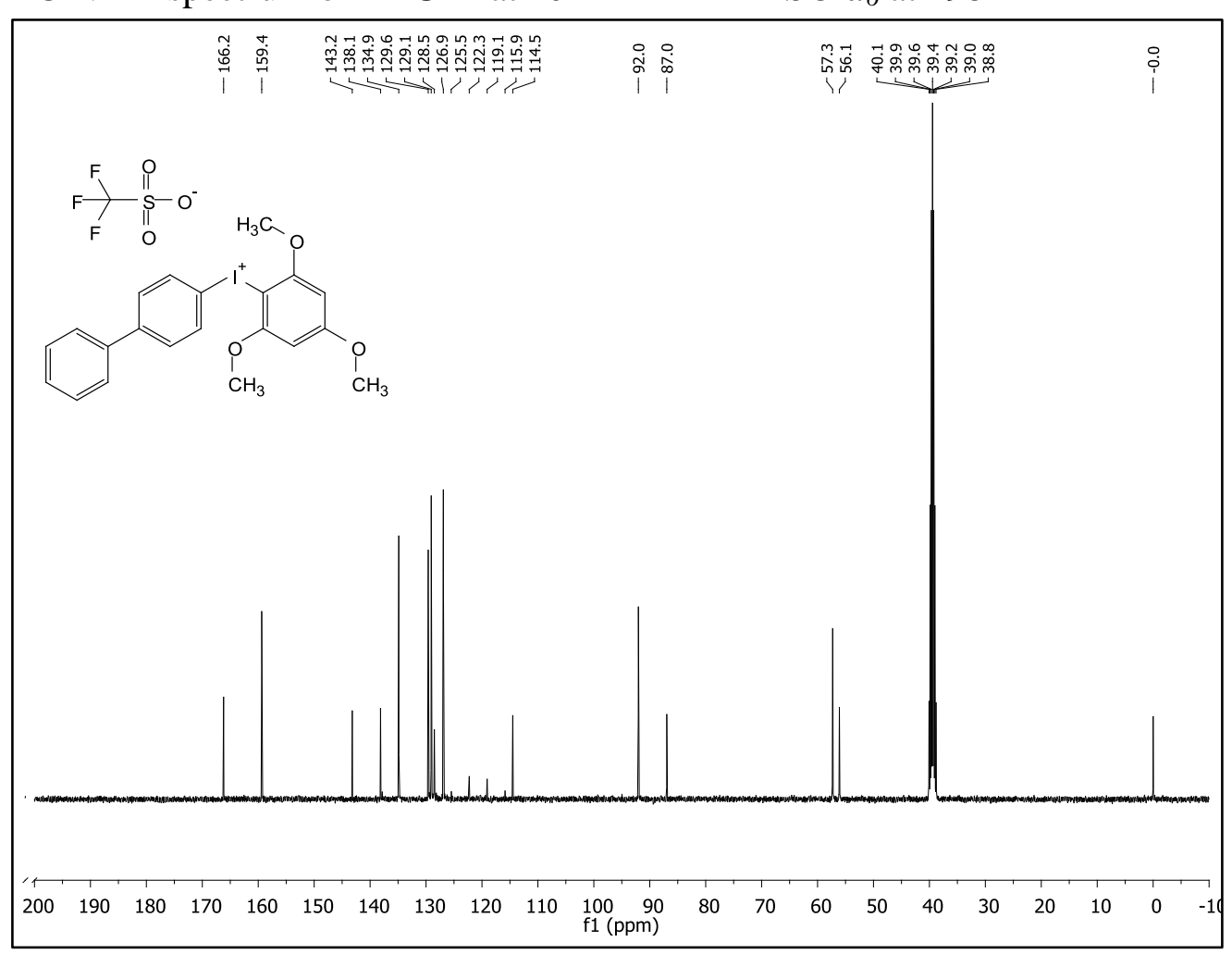


- ${ }^{19} \mathrm{~F}$ NMR spectrum of 14-OTf at $376 \mathrm{MHz}$ in DMSO- $d_{6}$ at $298 \mathrm{~K}$

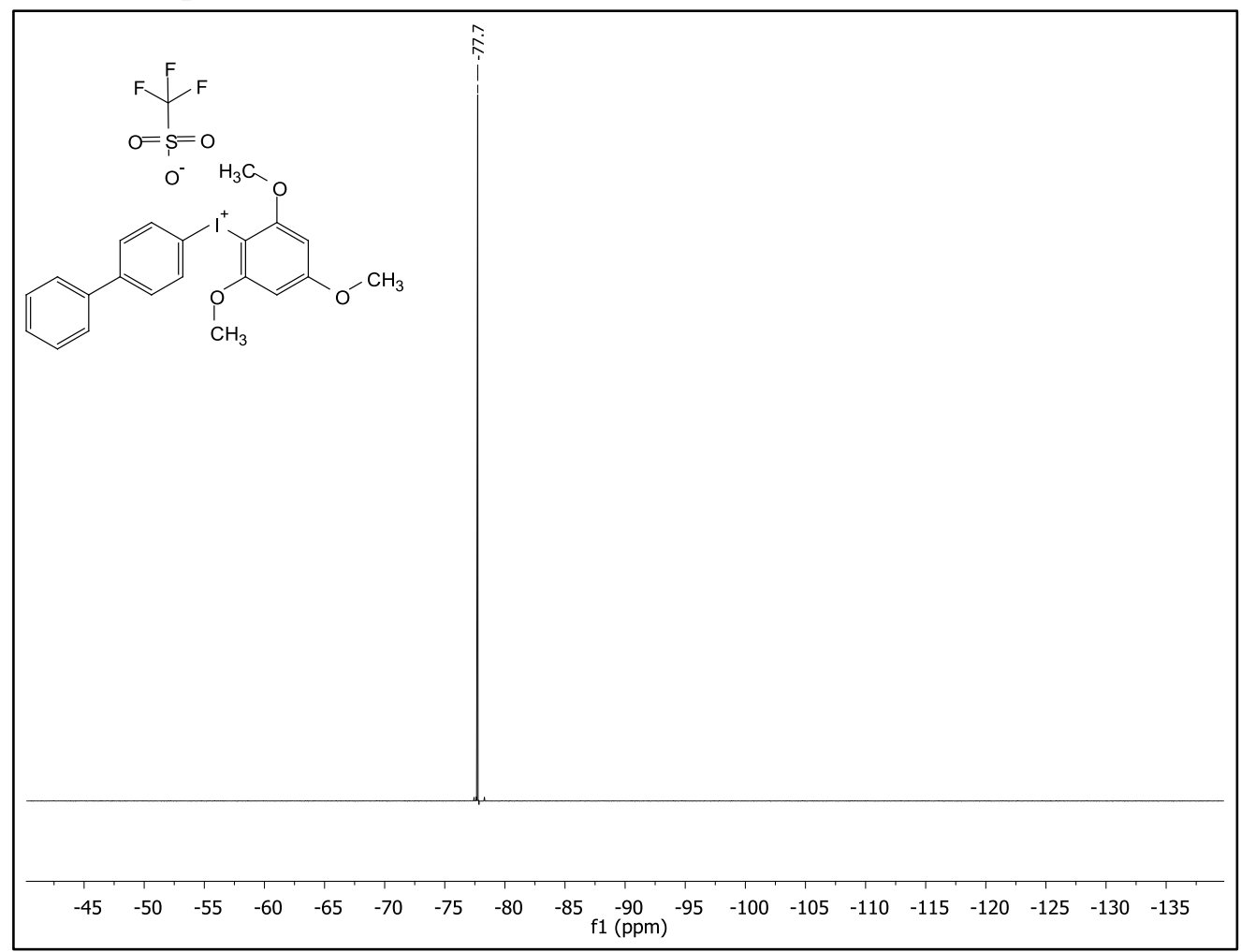

- ${ }^{1} \mathrm{H}$ NMR spectrum of $\mathbf{1 4 - \mathbf { P F } _ { 6 }}$ at $400 \mathrm{MHz}$ in DMSO- $d_{6}$ at $298 \mathrm{~K}$

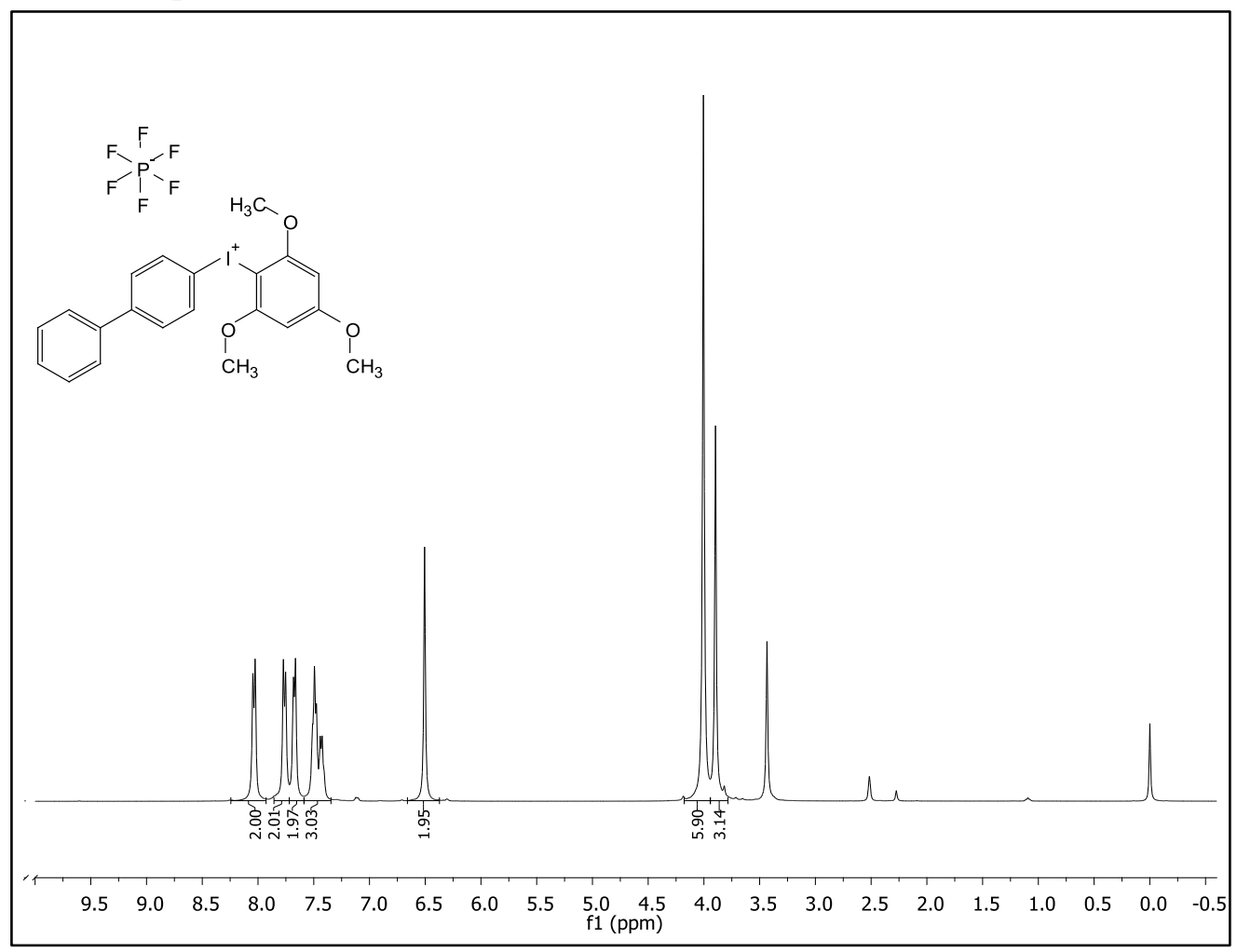


- ${ }^{13} \mathrm{C}$ NMR spectrum of $\mathbf{1 4 - \mathbf { P F } _ { \mathbf { 6 } }}$ at $101 \mathrm{MHz}$ in DMSO- $d_{6}$ at $298 \mathrm{~K}$

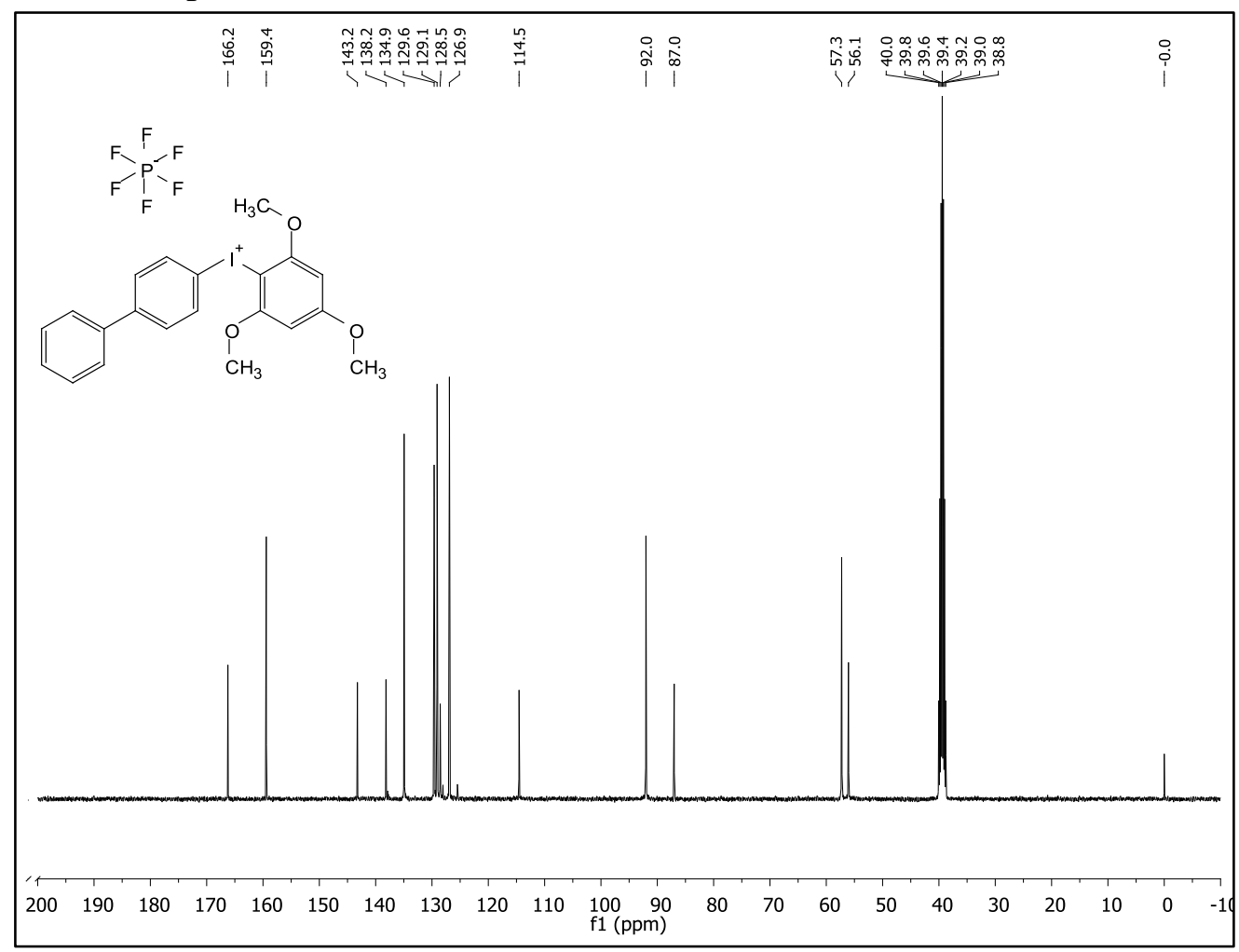

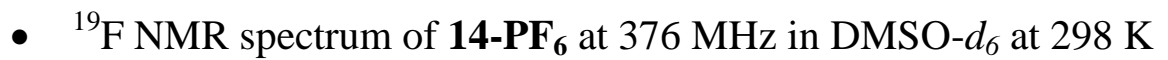

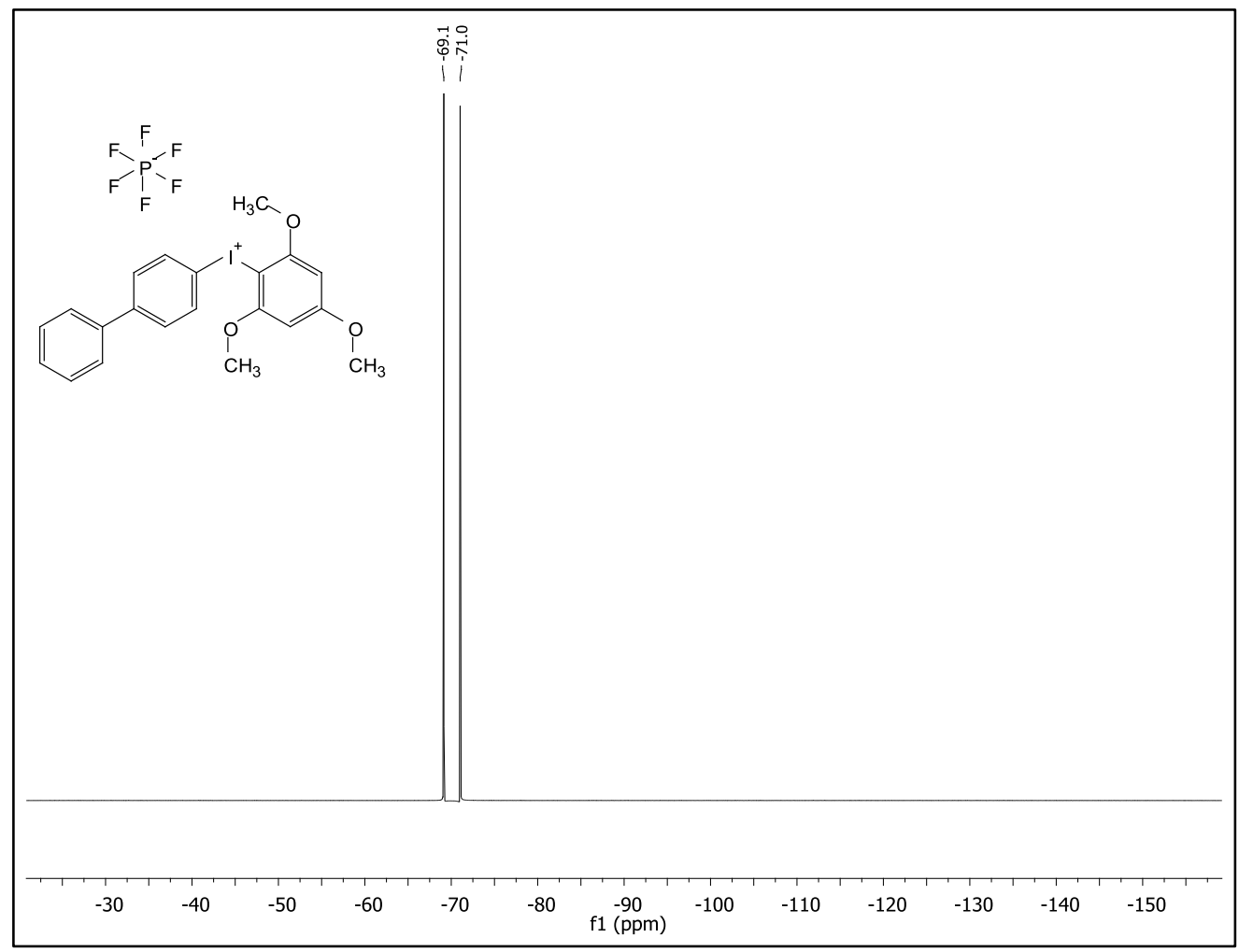


- ${ }^{1} \mathrm{H}$ NMR spectrum of $\mathbf{1 4 -} \mathbf{B F}_{4}$ at $400 \mathrm{MHz}$ in DMSO- $d_{6}$ at $298 \mathrm{~K}$

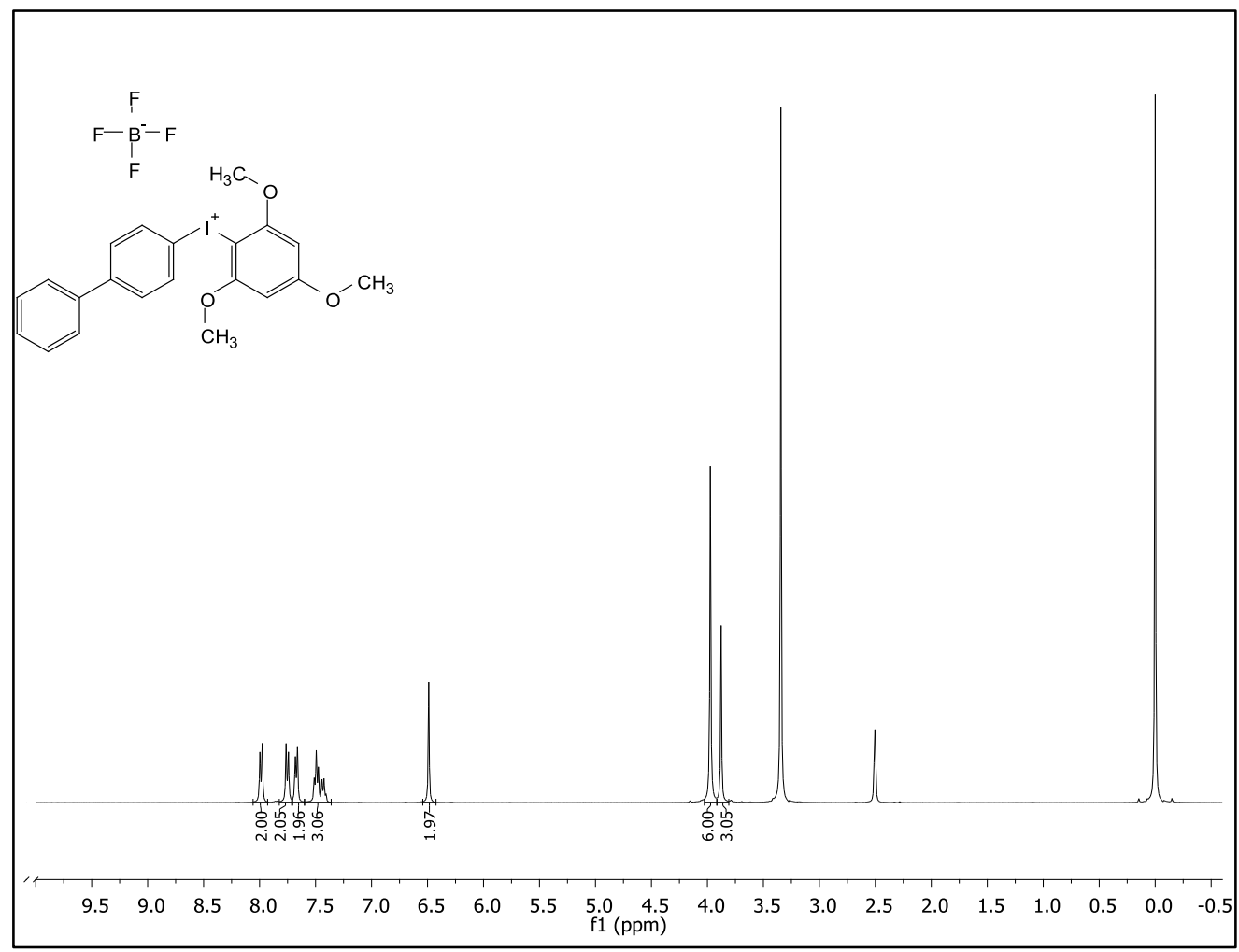

- ${ }^{13} \mathrm{C}$ NMR spectrum of $\mathbf{1 4 - \mathbf { B F } _ { 4 }}$ at $101 \mathrm{MHz}$ in DMSO- $d_{6}$ at $298 \mathrm{~K}$

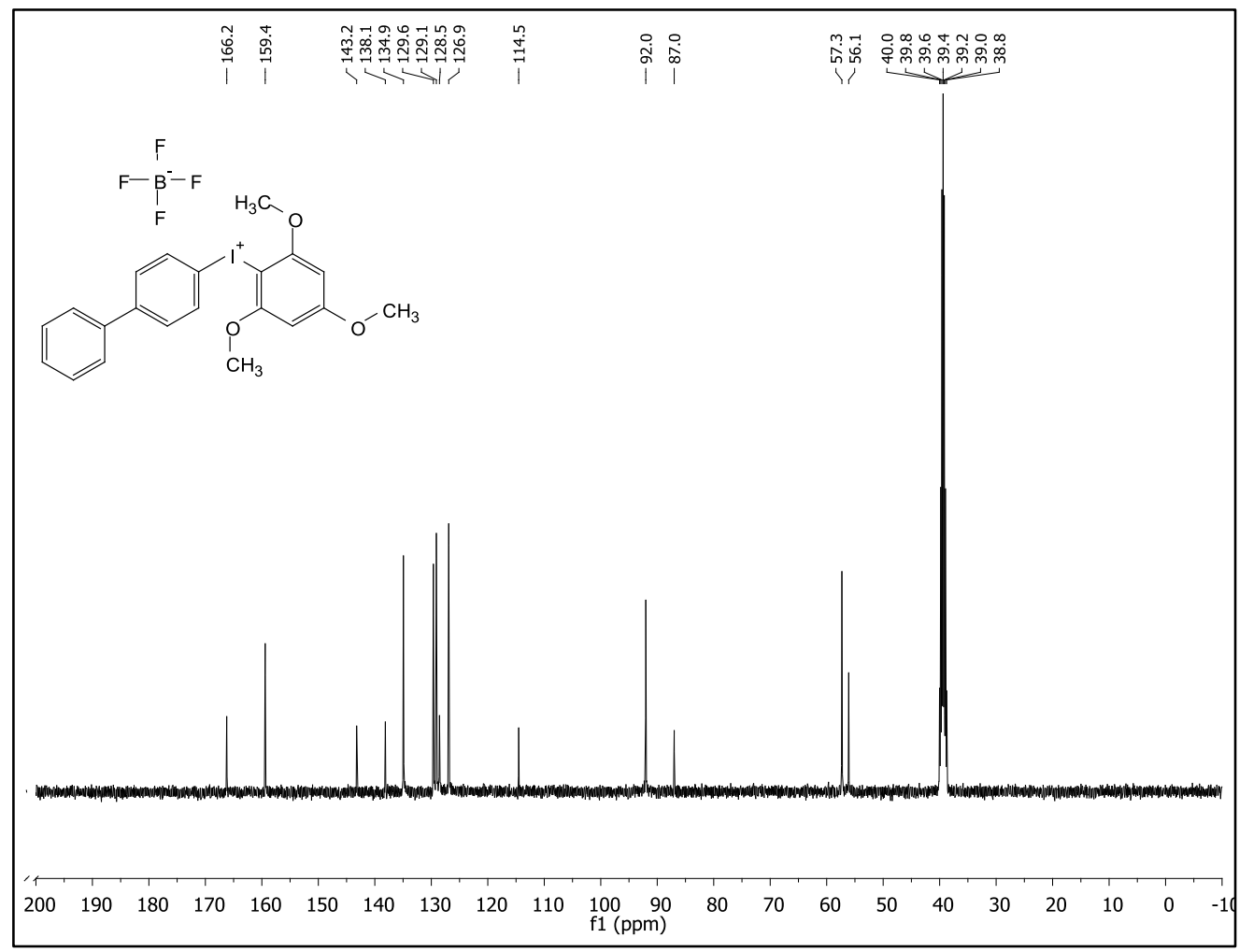


- ${ }^{19} \mathrm{~F}$ NMR spectrum of $\mathbf{1 4 - \mathbf { B F } _ { \mathbf { 4 } }}$ at $376 \mathrm{MHz}$ in DMSO- $d_{6}$ at $298 \mathrm{~K}$

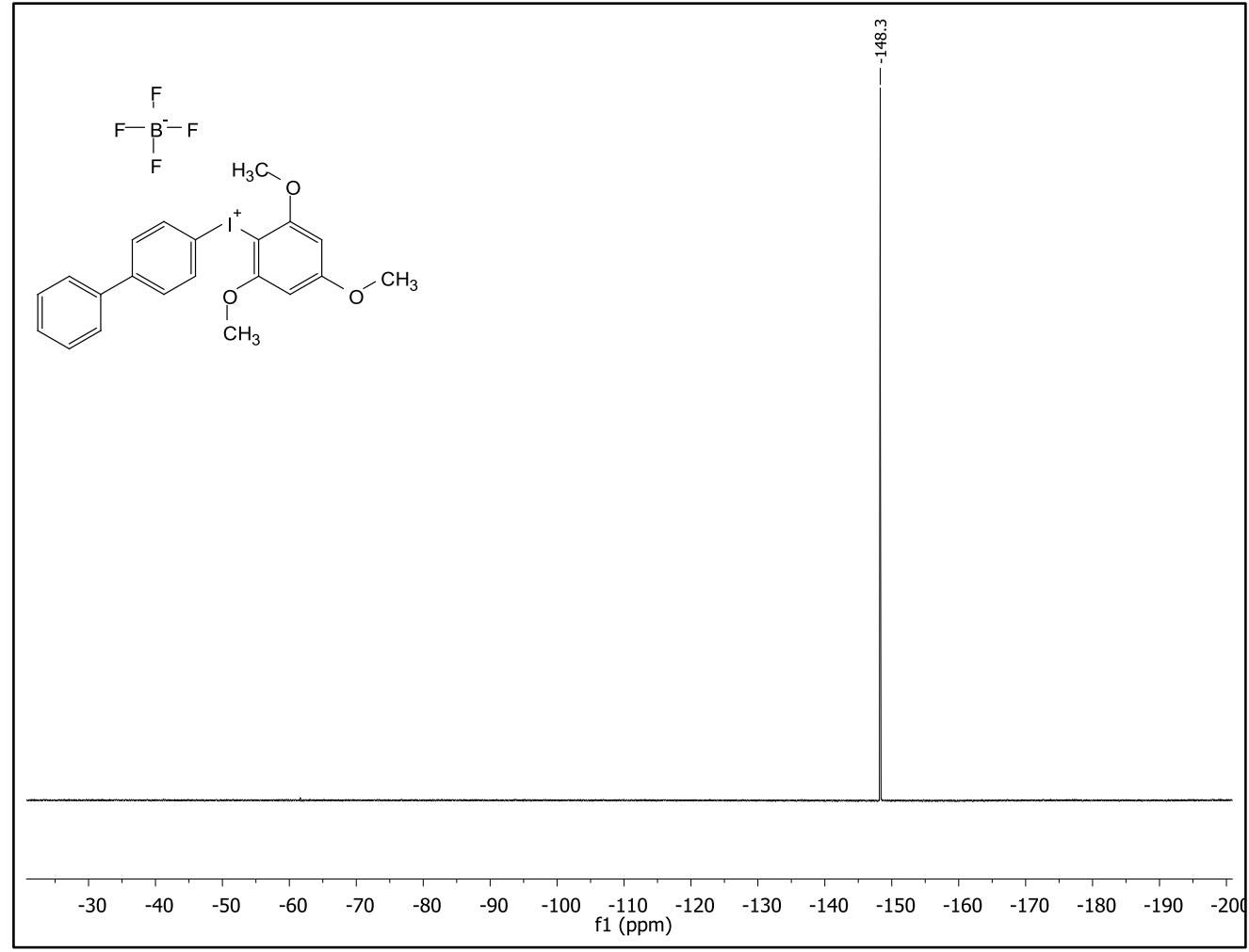

- $\quad{ }^{1} \mathrm{H}$ NMR spectrum of 4-Br at $600 \mathrm{MHz}$ in DMSO- $d_{6}$ at $298 \mathrm{~K}$

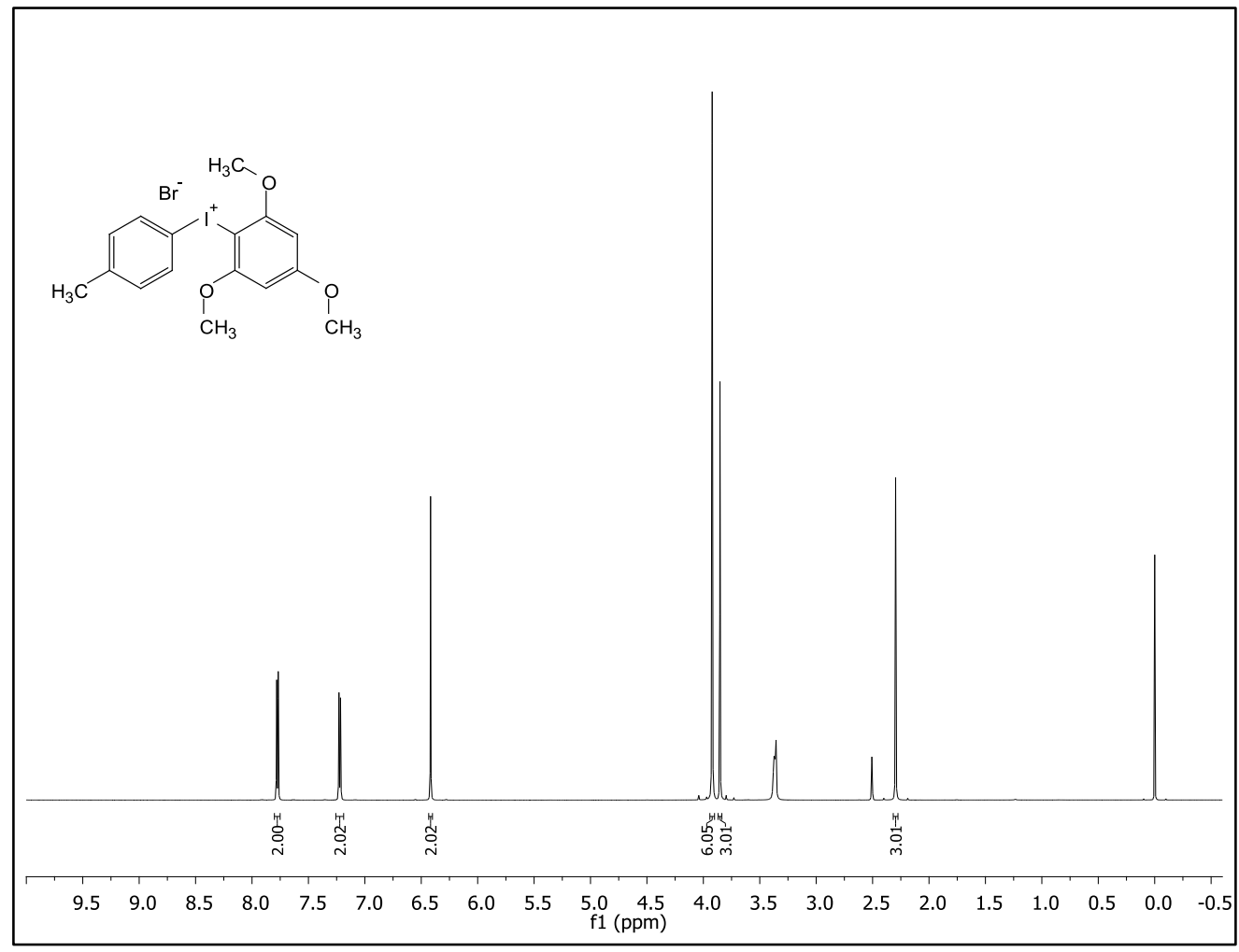


- ${ }^{13} \mathrm{C}$ NMR spectrum of 4-Br at $101 \mathrm{MHz}$ in DMSO- $d_{6}$ at $298 \mathrm{~K}$

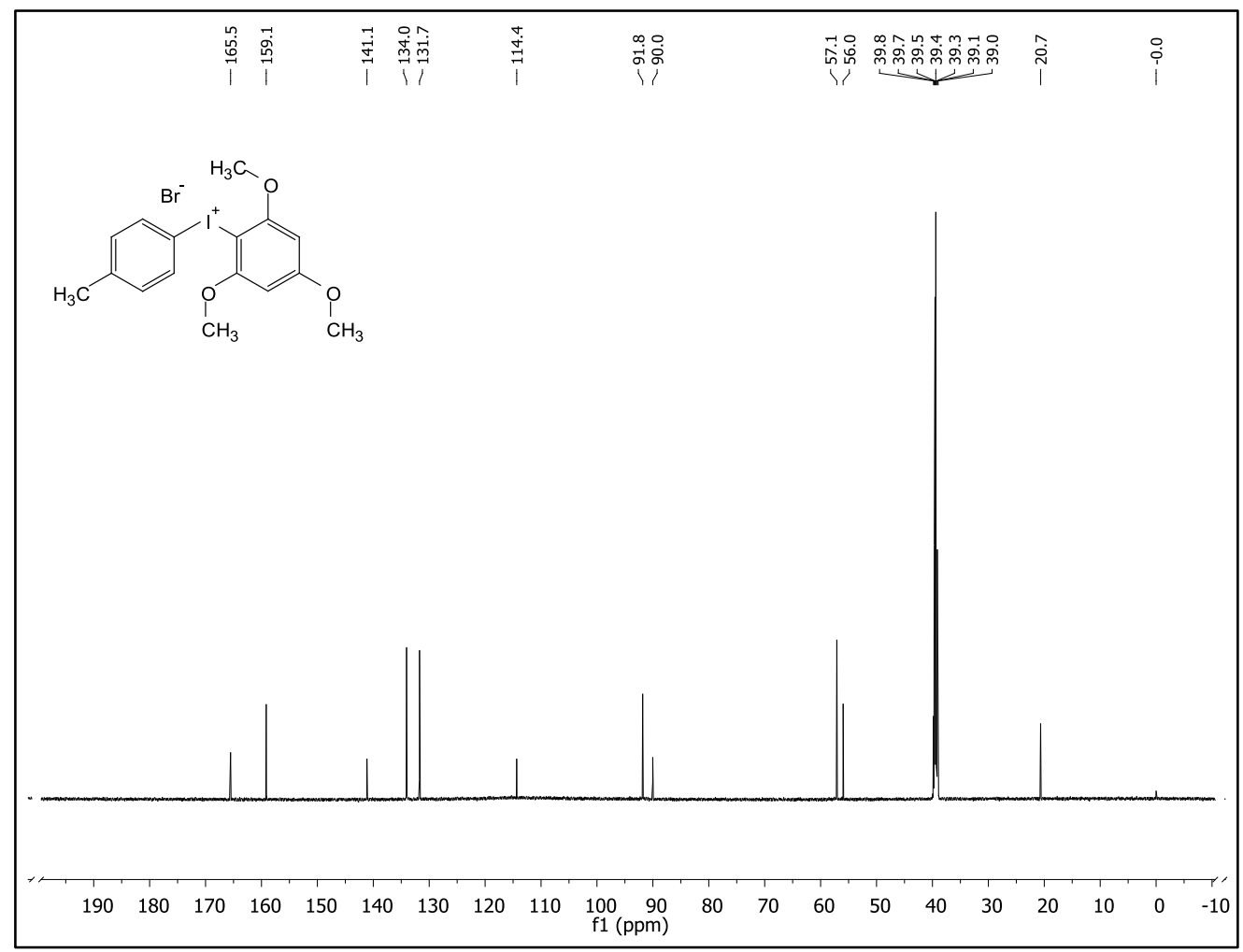

- ${ }^{1} \mathrm{H}$ NMR spectrum of 22-PF 6 at $600 \mathrm{MHz}$ in DMSO- $d_{6}$ at $298 \mathrm{~K}$

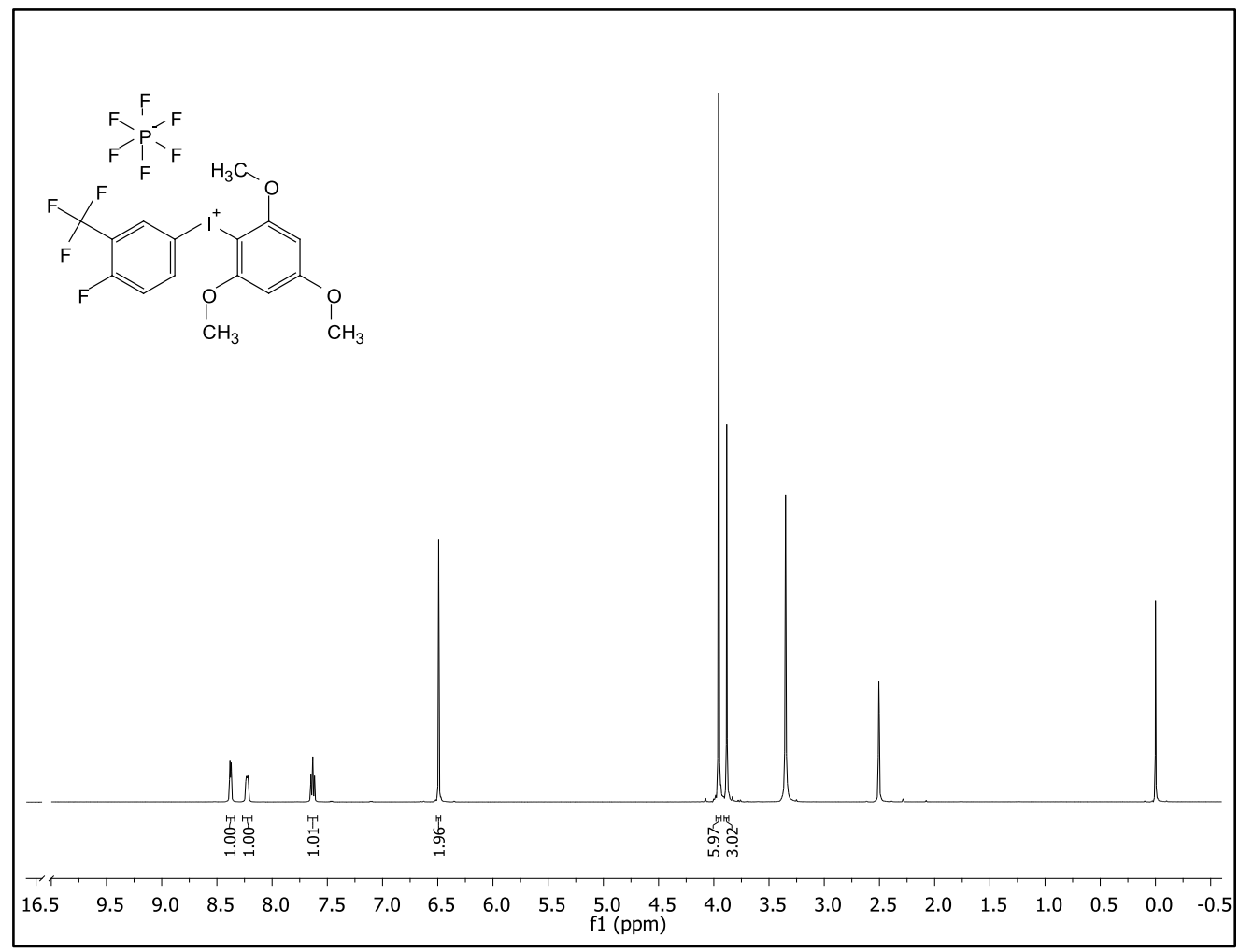


- ${ }^{13} \mathrm{C}$ NMR spectrum of $\mathbf{2 2 - \mathbf { P F } _ { \mathbf { 6 } }}$ at $101 \mathrm{MHz}$ in DMSO- $d_{6}$ at $298 \mathrm{~K}$

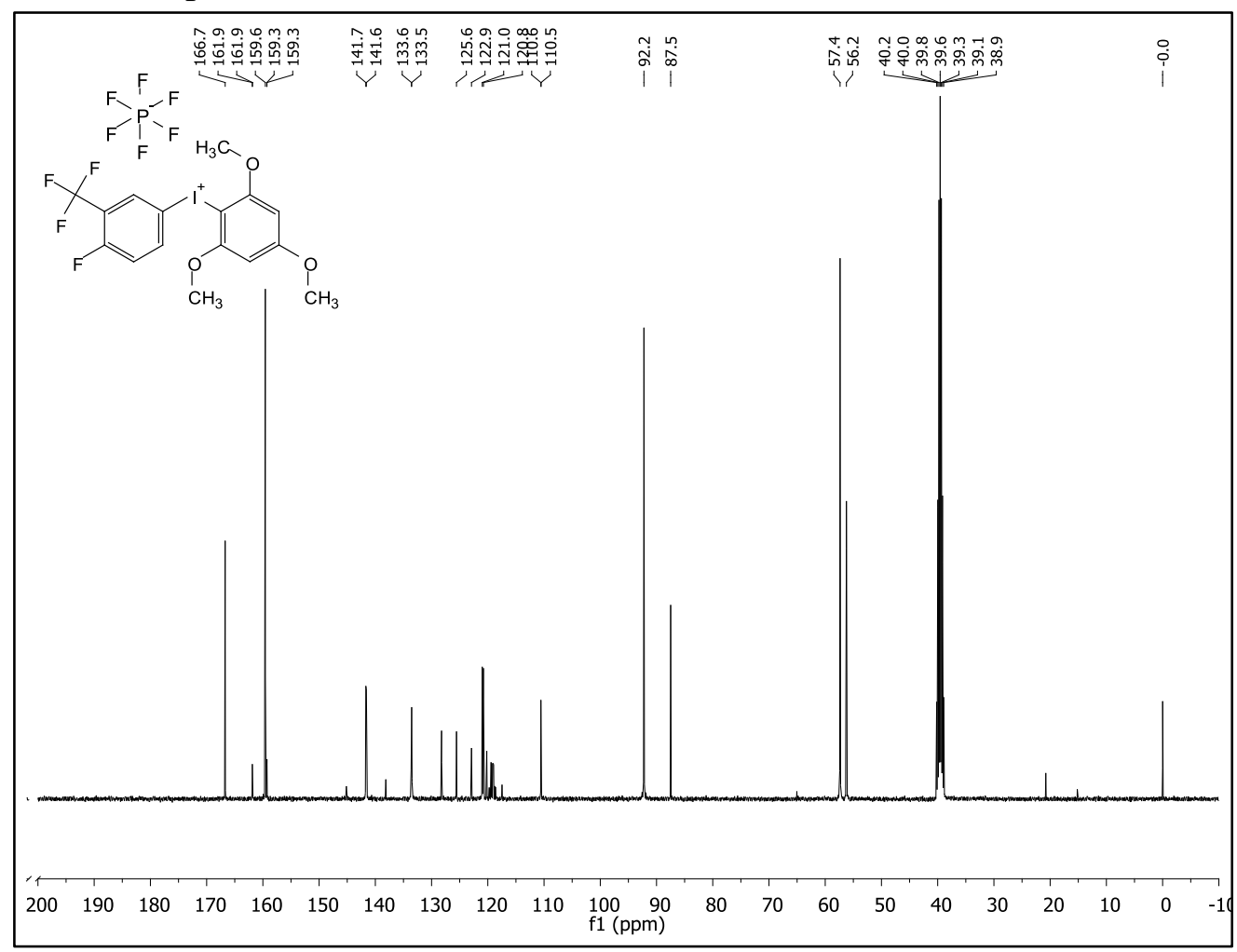

- ${ }^{19}$ F NMR spectrum of $22-\mathbf{P F}_{\mathbf{6}}$ at $376 \mathrm{MHz}$ in DMSO- $d_{6}$ at $298 \mathrm{~K}$

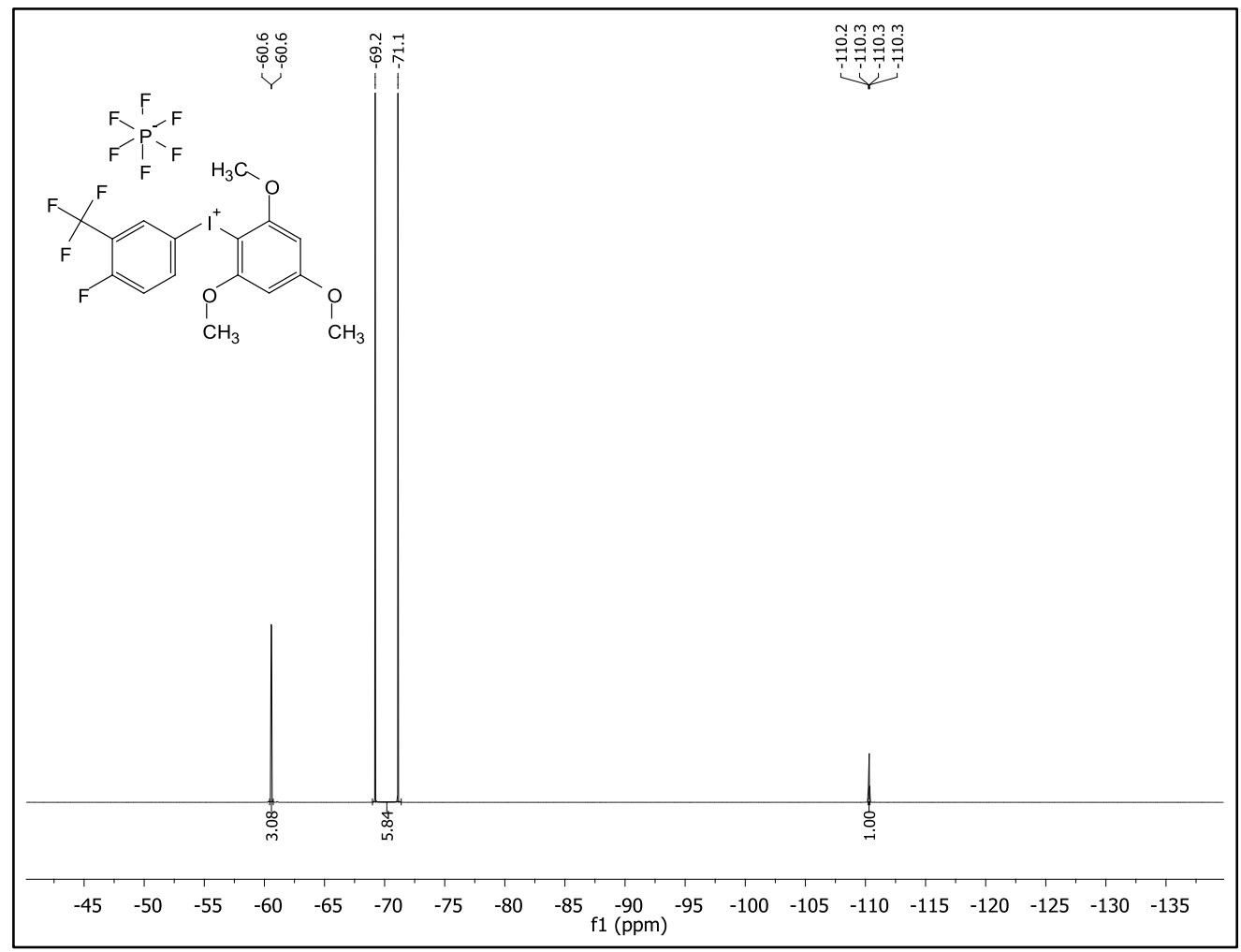


- ${ }^{1} \mathrm{H}$ NMR spectrum of 29-Br at $400 \mathrm{MHz}$ in DMSO- $d_{6}$ at $298 \mathrm{~K}$

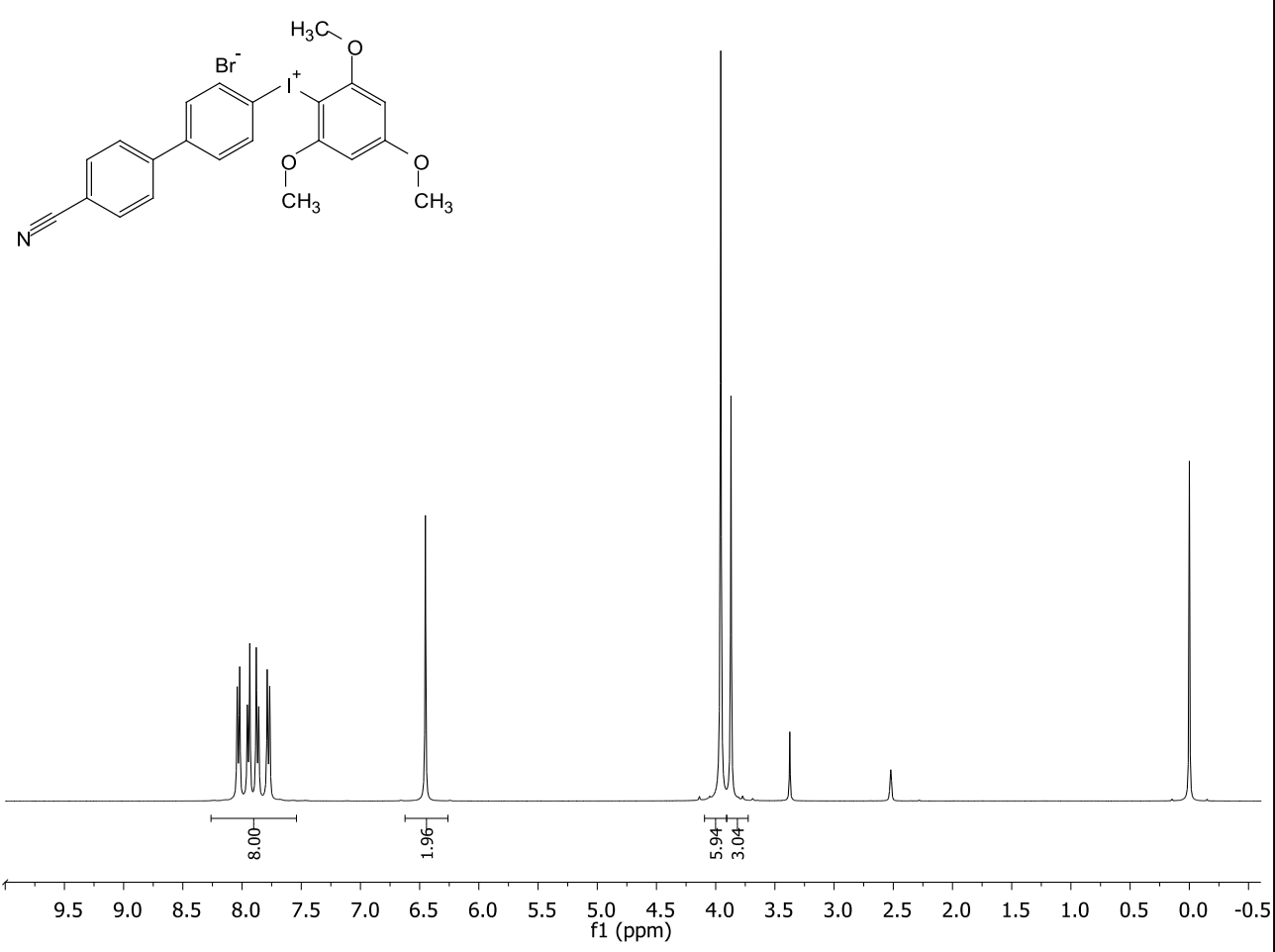

- ${ }^{13} \mathrm{C}$ NMR spectrum of 29-Br at $101 \mathrm{MHz}$ in DMSO- $d_{6}$ at $298 \mathrm{~K}$

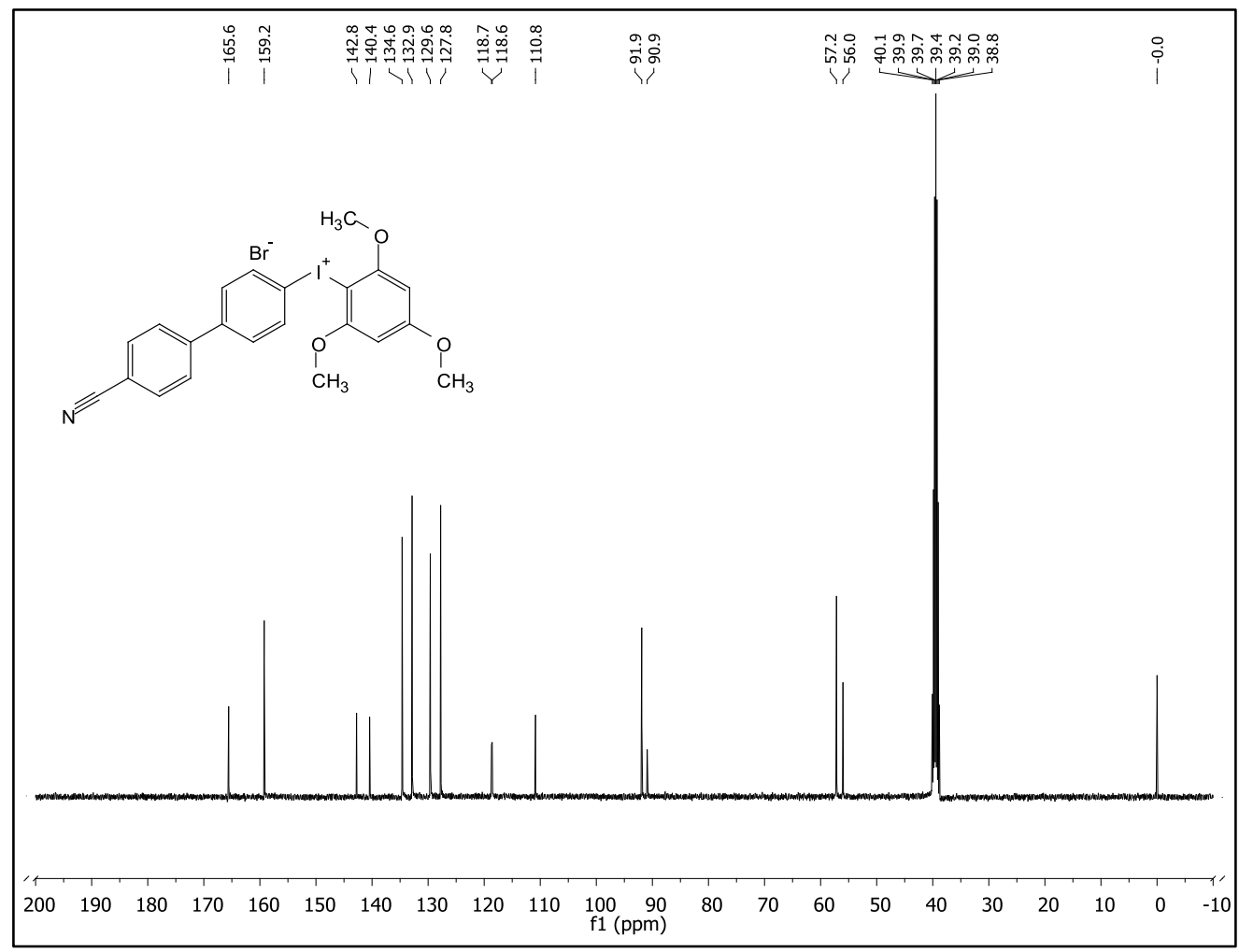


S57

- ${ }^{1} \mathrm{H}$ NMR spectrum of 23-Br at $400 \mathrm{MHz}$ in DMSO- $d_{6}$ at $298 \mathrm{~K}$

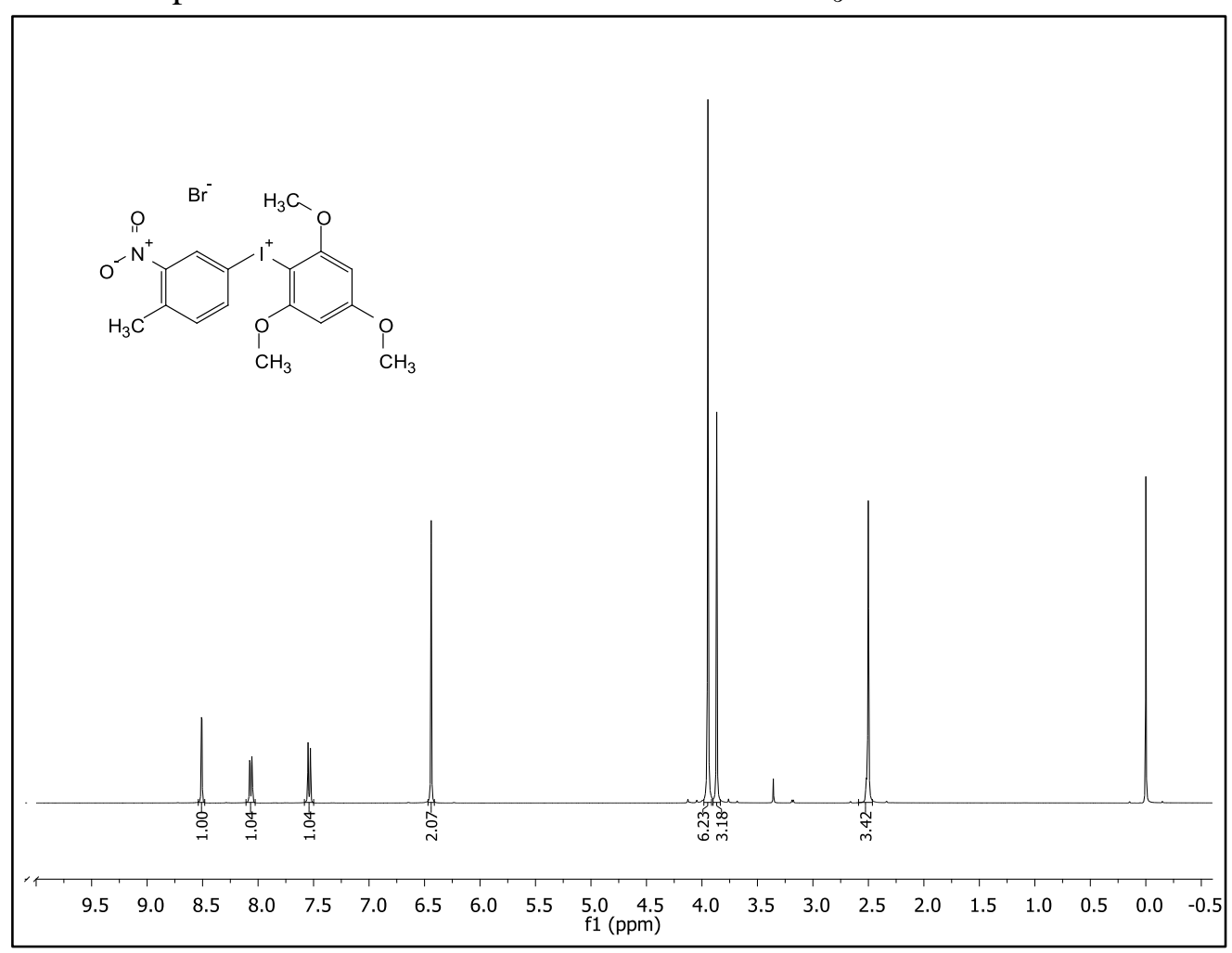

- ${ }^{13} \mathrm{C}$ NMR spectrum of $\mathbf{2 3 - B r}$ at $101 \mathrm{MHz}$ in DMSO- $d_{6}$ at $298 \mathrm{~K}$

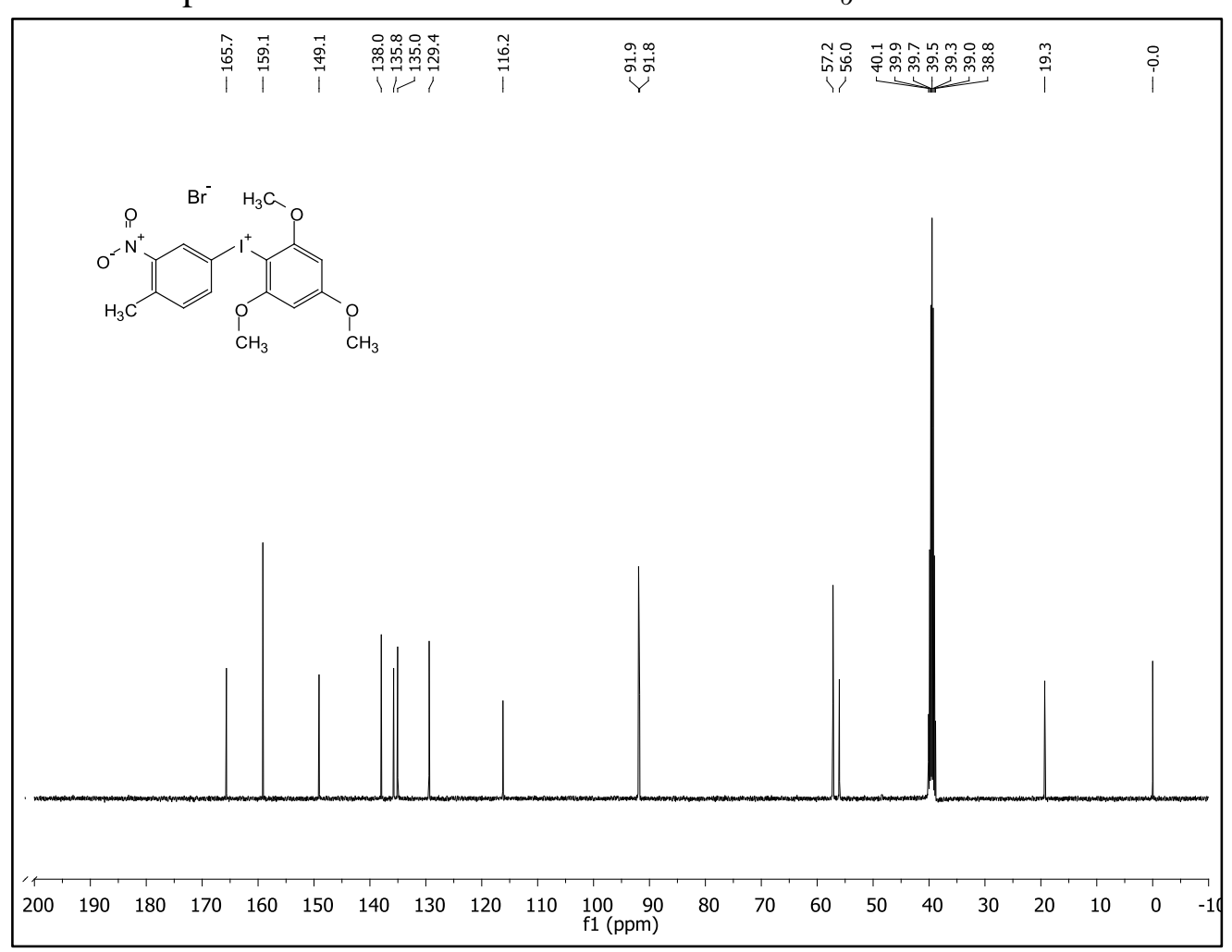


- ${ }^{1} \mathrm{H}$ NMR spectrum of 26-Br at $400 \mathrm{MHz}$ in DMSO- $d_{6}$ at $298 \mathrm{~K}$

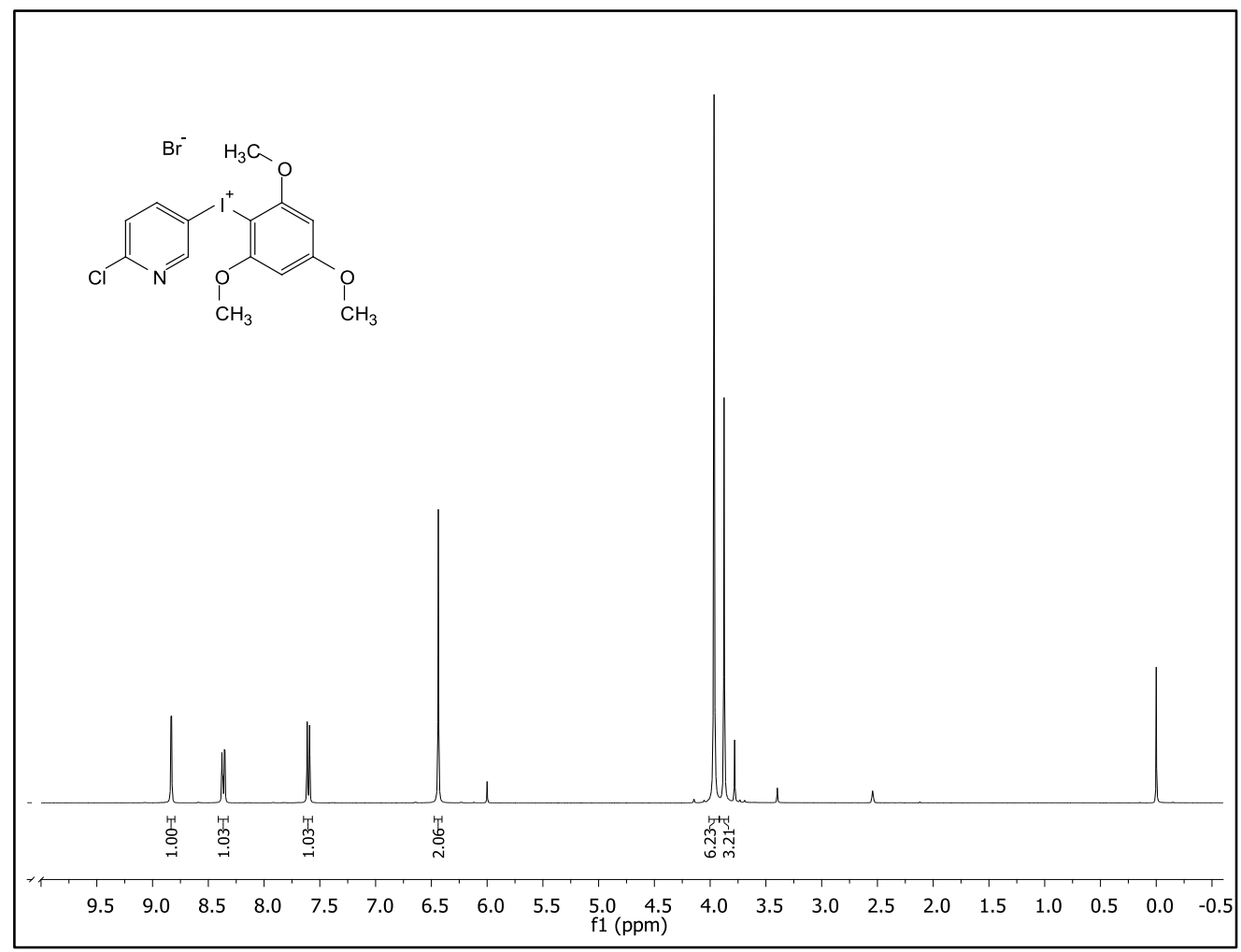

- ${ }^{13} \mathrm{C}$ NMR spectrum of 26-Br at $101 \mathrm{MHz}$ in DMSO- $d_{6}$ at $298 \mathrm{~K}$

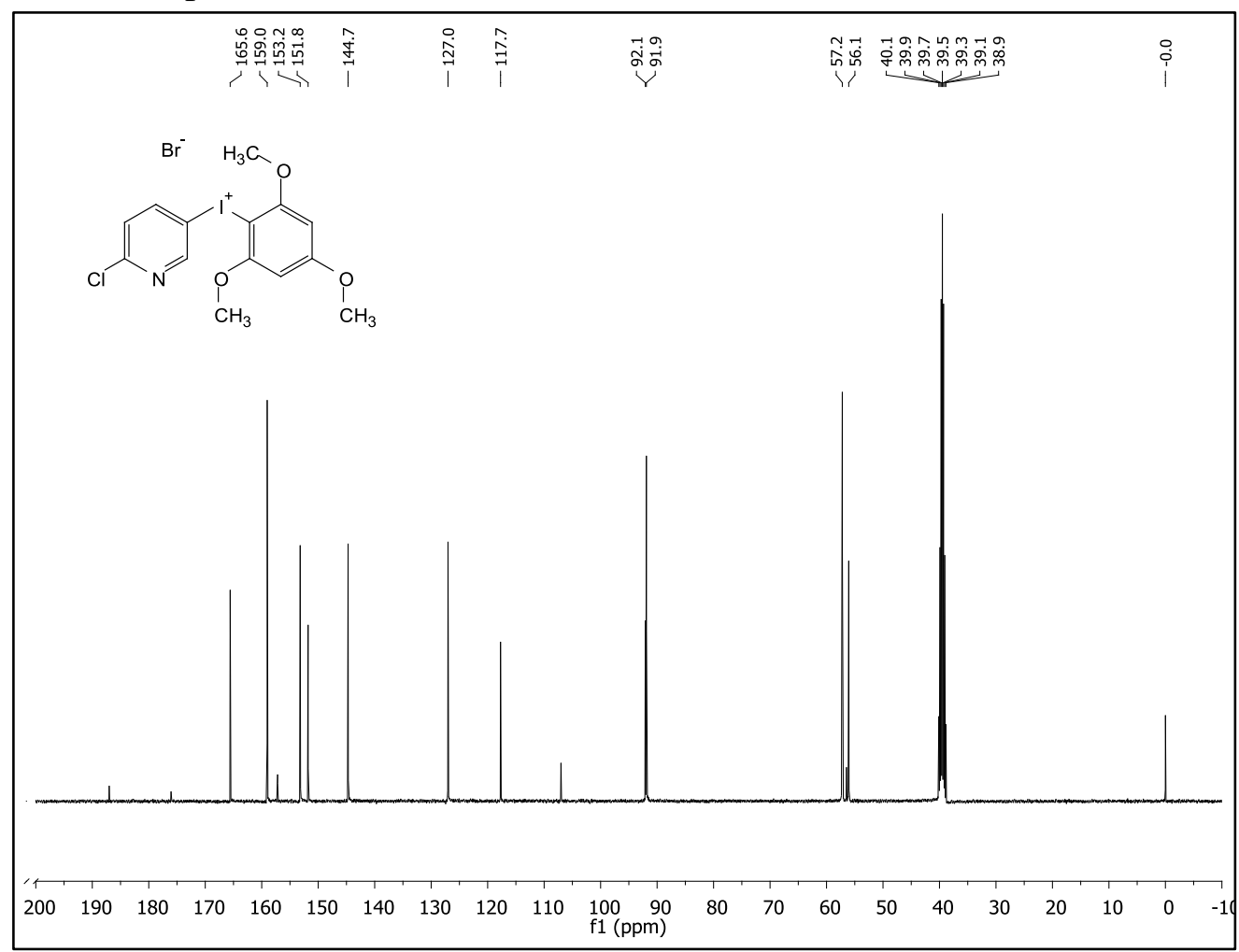




$$
5
$$


- ${ }^{1} \mathrm{H}$ NMR spectrum of $\mathbf{3 1}$ at $600 \mathrm{MHz}$ in $\mathrm{CDCl}_{3}$ at $298 \mathrm{~K}$

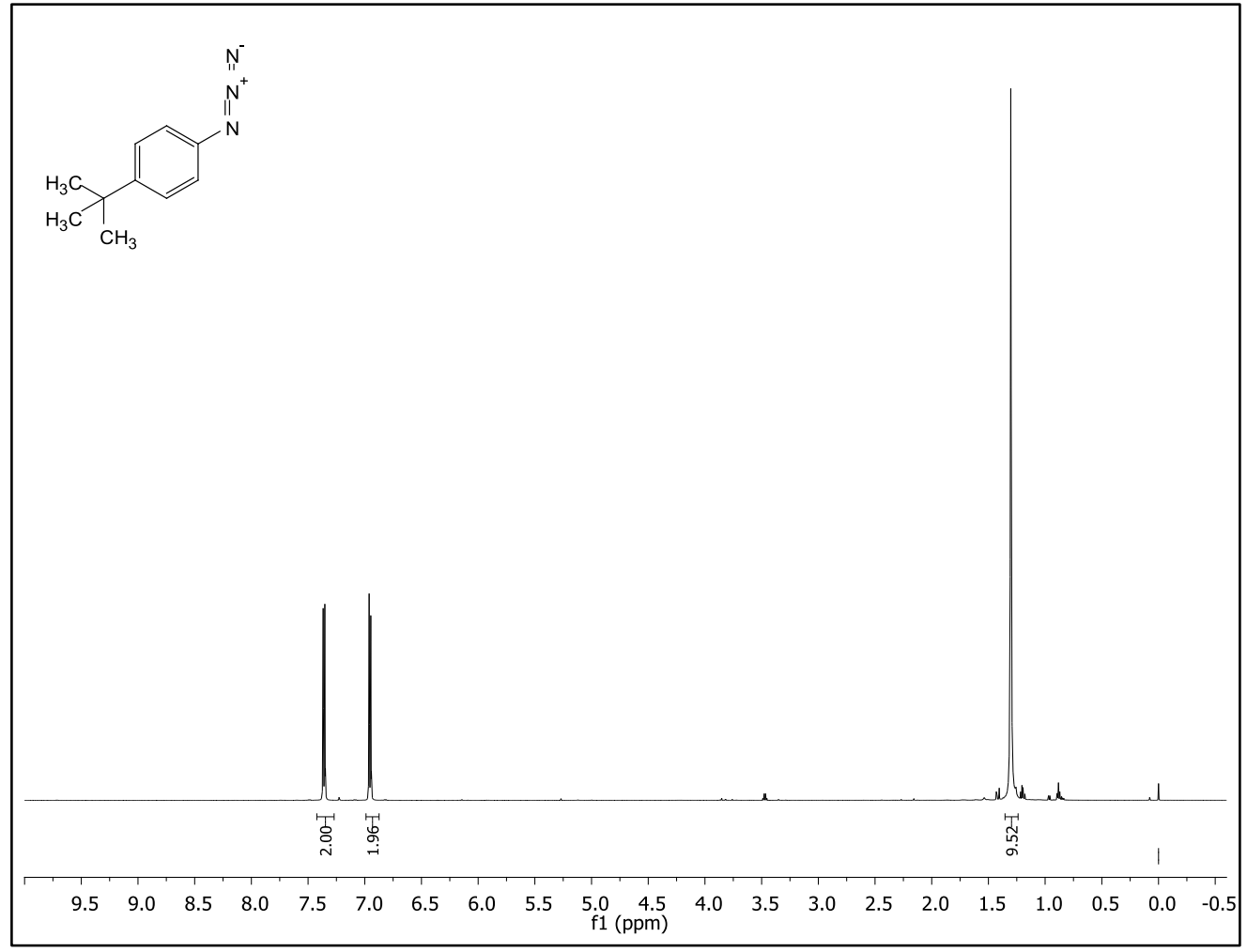

- ${ }^{13} \mathrm{C}$ NMR spectrum of $\mathbf{3 1}$ at $151 \mathrm{MHz}$ in $\mathrm{CDCl}_{3}$ at $298 \mathrm{~K}$

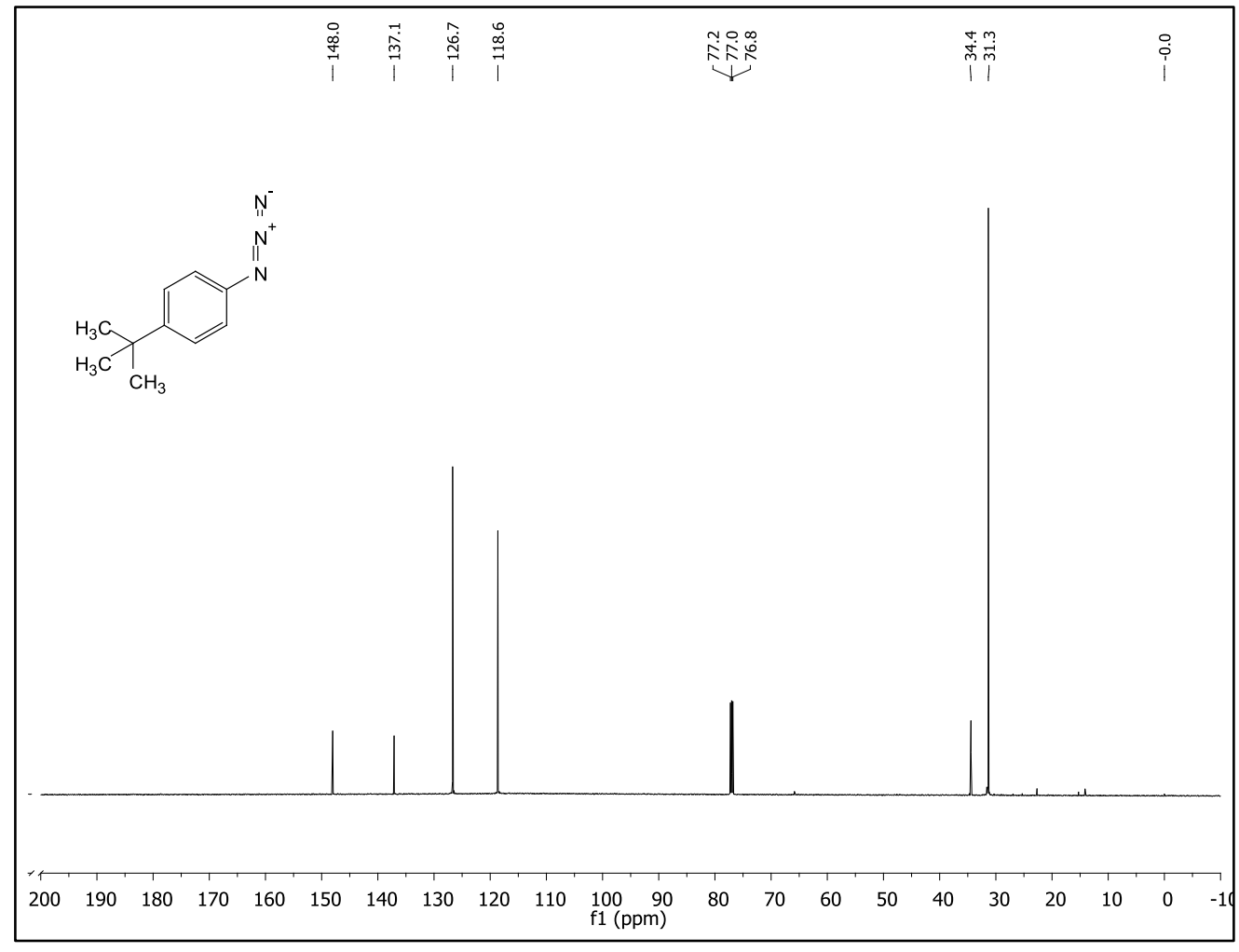


- ${ }^{1} \mathrm{H}$ NMR spectrum of $\mathbf{3 2}$ at $600 \mathrm{MHz}$ in $\mathrm{CDCl}_{3}$ at $298 \mathrm{~K}$

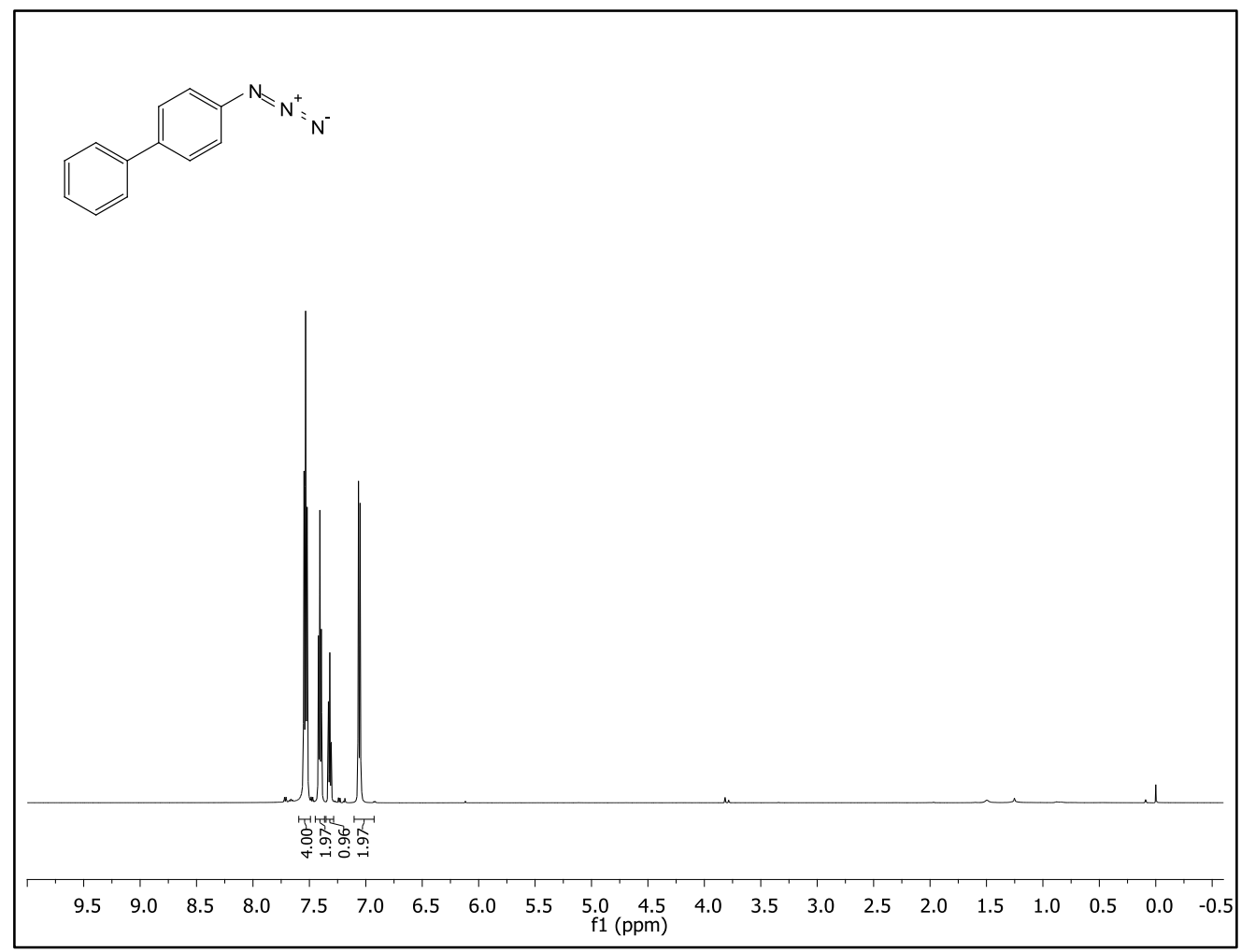

- ${ }^{13} \mathrm{C}$ NMR spectrum of $\mathbf{3 2}$ at $151 \mathrm{MHz}$ in $\mathrm{CDCl}_{3}$ at $298 \mathrm{~K}$

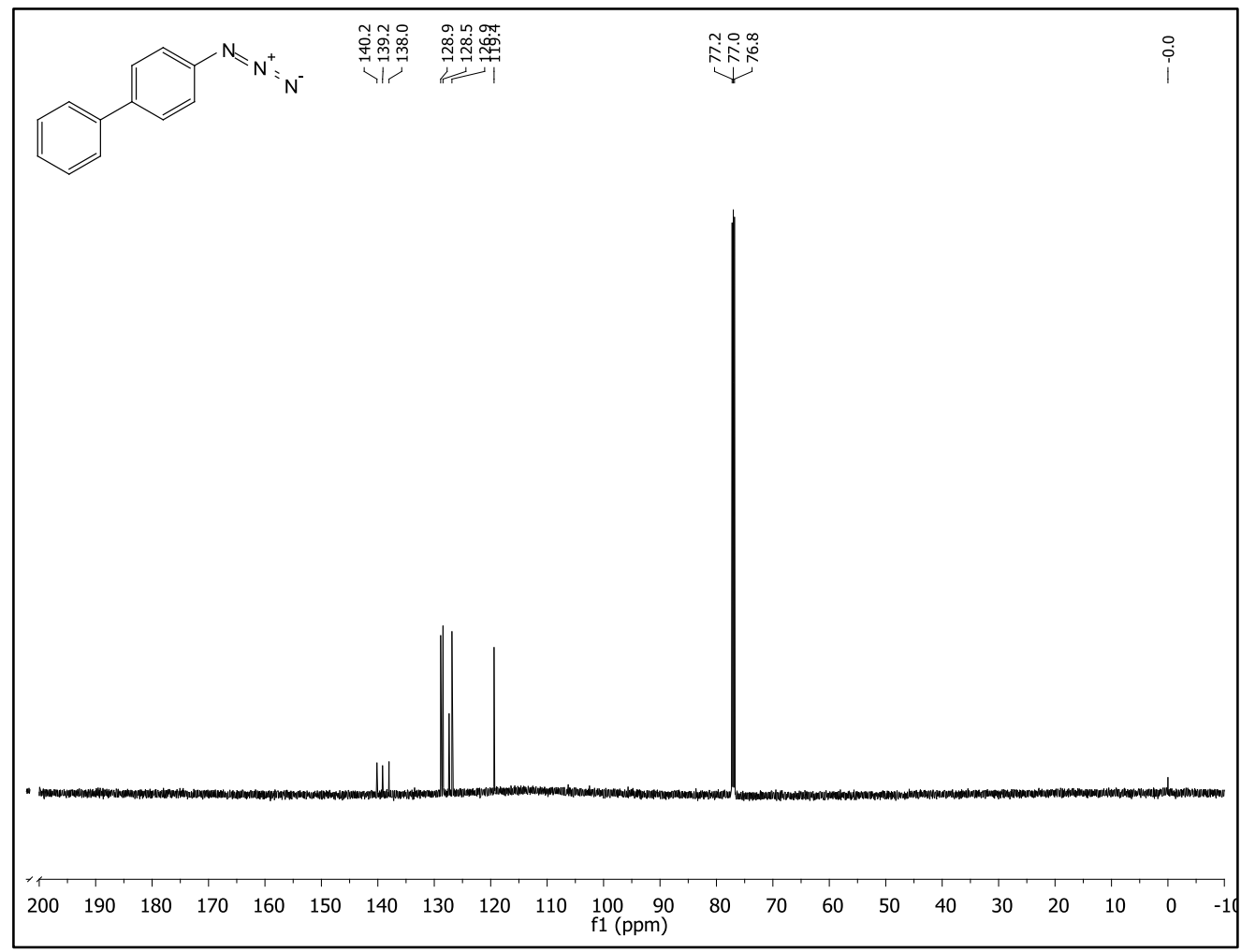


S62

- ${ }^{1} \mathrm{H}$ NMR spectrum of 33 at $400 \mathrm{MHz}$ in $\mathrm{CDCl}_{3}$ at $298 \mathrm{~K}$

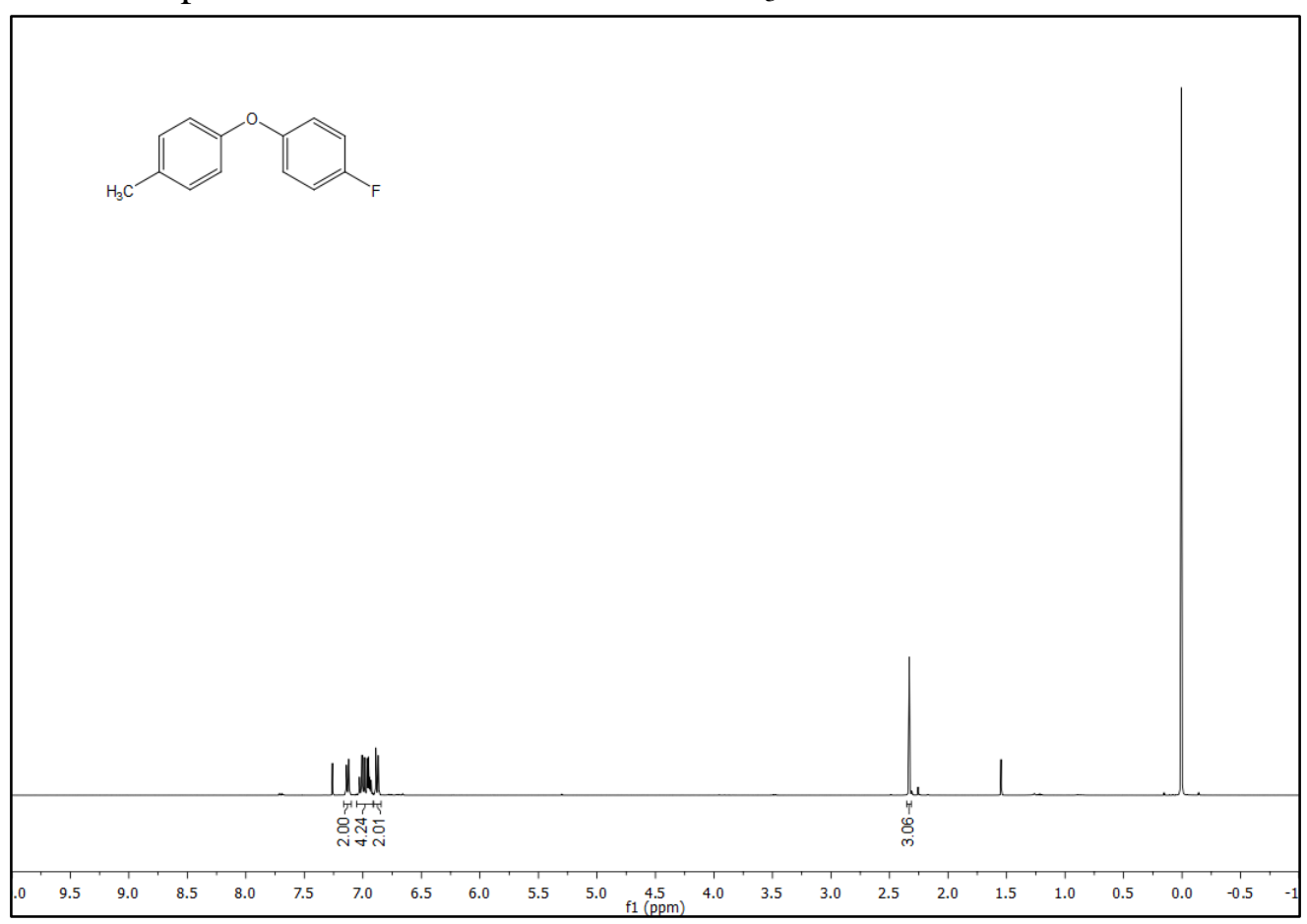

- ${ }^{13} \mathrm{C}$ NMR spectrum of $\mathbf{3 3}$ at $101 \mathrm{MHz}$ in $\mathrm{CDCl}_{3}$ at $298 \mathrm{~K}$

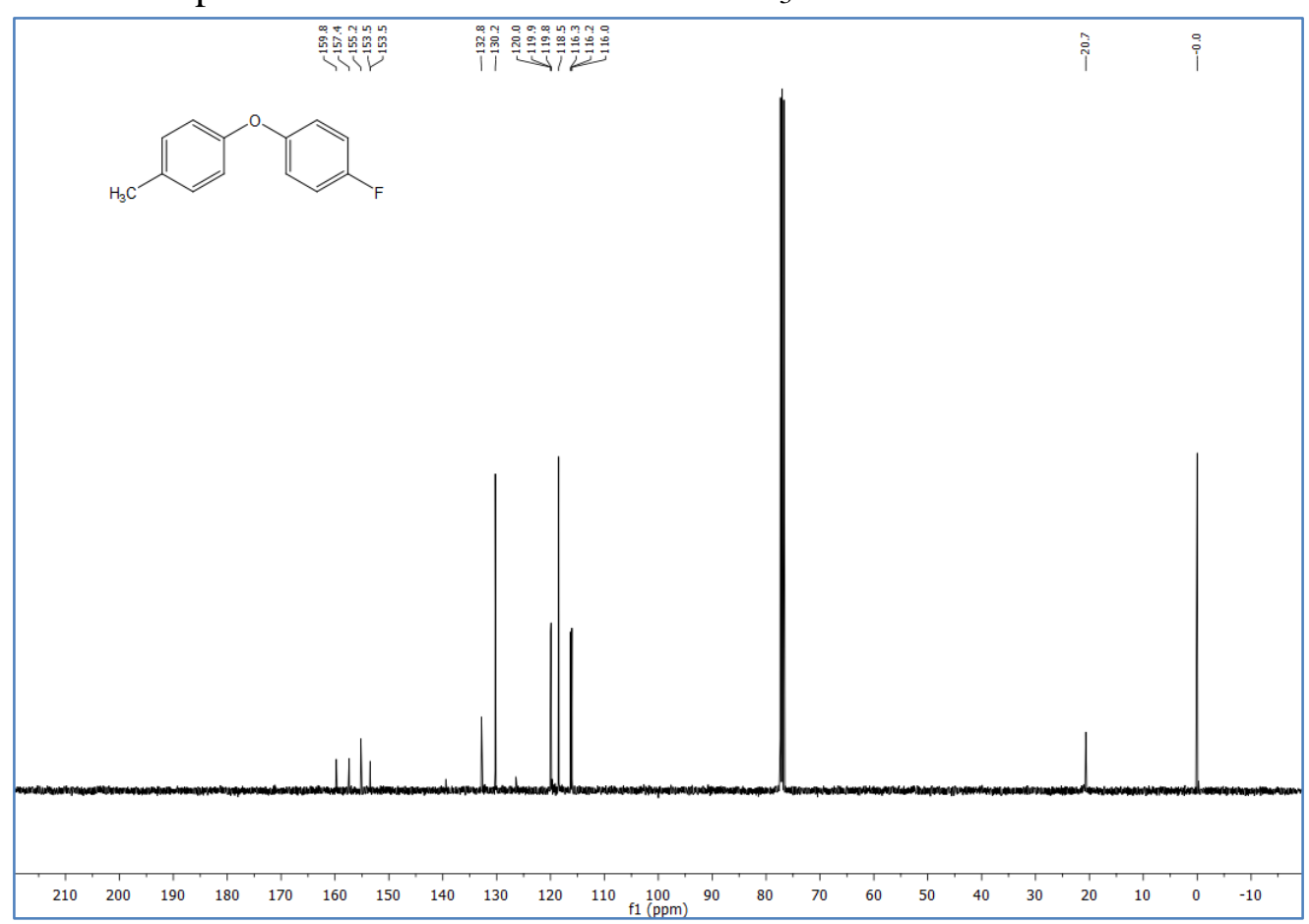


S63

- ${ }^{19} \mathrm{~F}$ NMR spectrum of 33 at $376 \mathrm{MHz}$ in $\mathrm{CDCl}_{3}$ at $298 \mathrm{~K}$

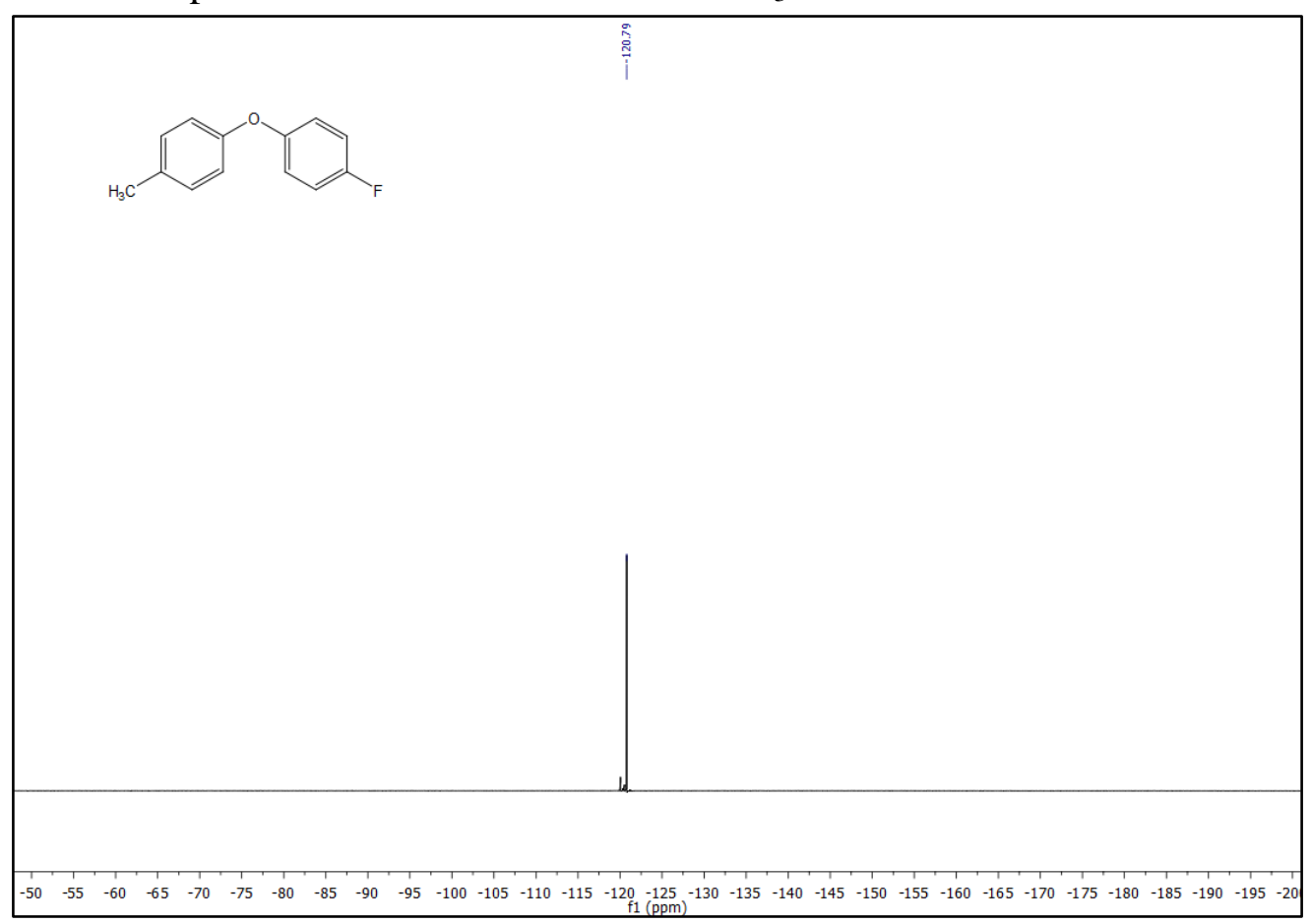

- ${ }^{1} \mathrm{H}$ NMR spectrum of 34 at $400 \mathrm{MHz}$ in $\mathrm{CDCl}_{3}$ at $298 \mathrm{~K}$

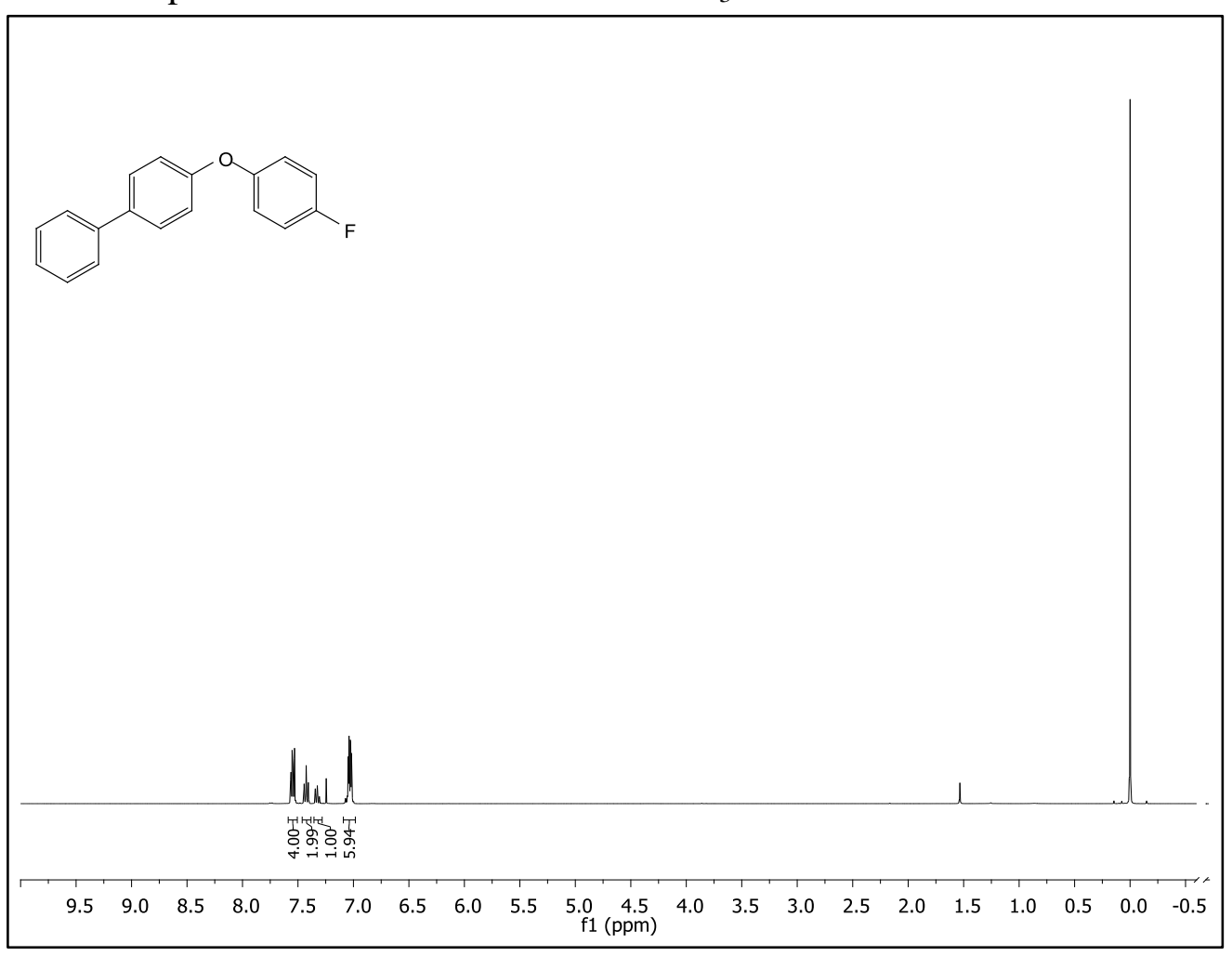


S64

- ${ }^{13} \mathrm{C}$ NMR spectrum of $\mathbf{3 4}$ at $101 \mathrm{MHz}$ in $\mathrm{CDCl}_{3}$ at $298 \mathrm{~K}$

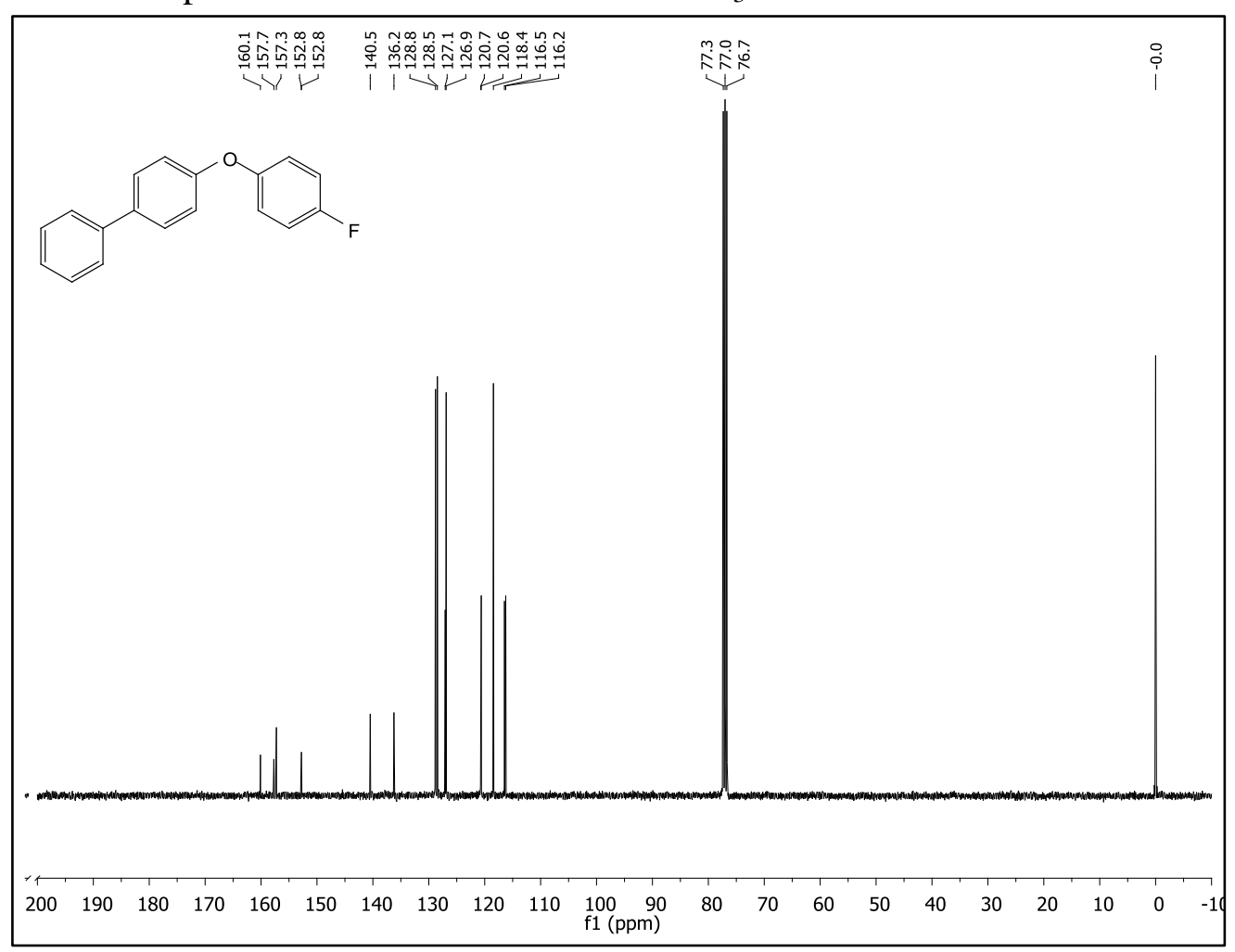

- ${ }^{19} \mathrm{~F}$ NMR spectrum of $\mathbf{3 4}$ at $376 \mathrm{MHz}$ in $\mathrm{CDCl}_{3}$ at $298 \mathrm{~K}$

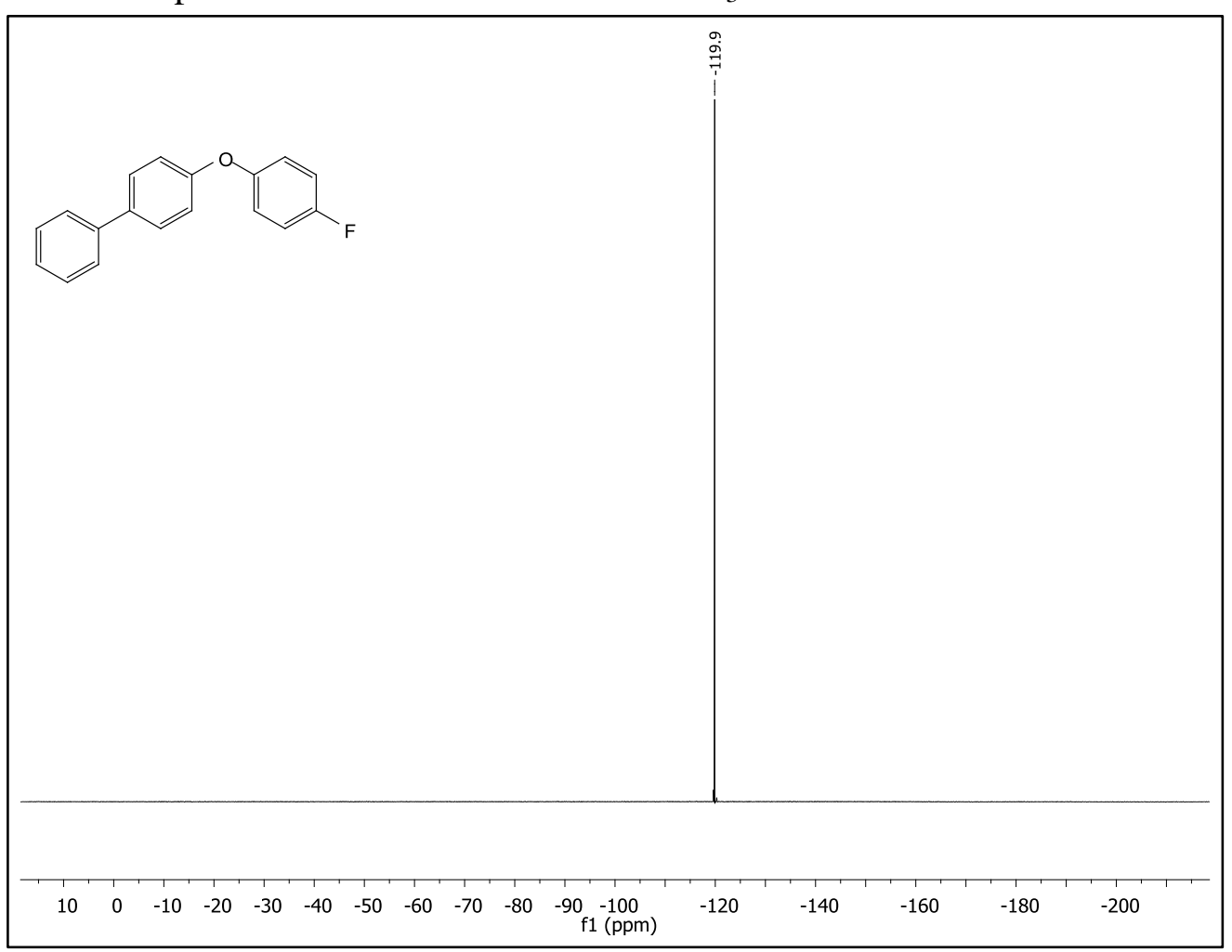


S65

- ${ }^{1} \mathrm{H}$ NMR spectrum of 35 at $400 \mathrm{MHz}$ in $\mathrm{CDCl}_{3}$ at $298 \mathrm{~K}$

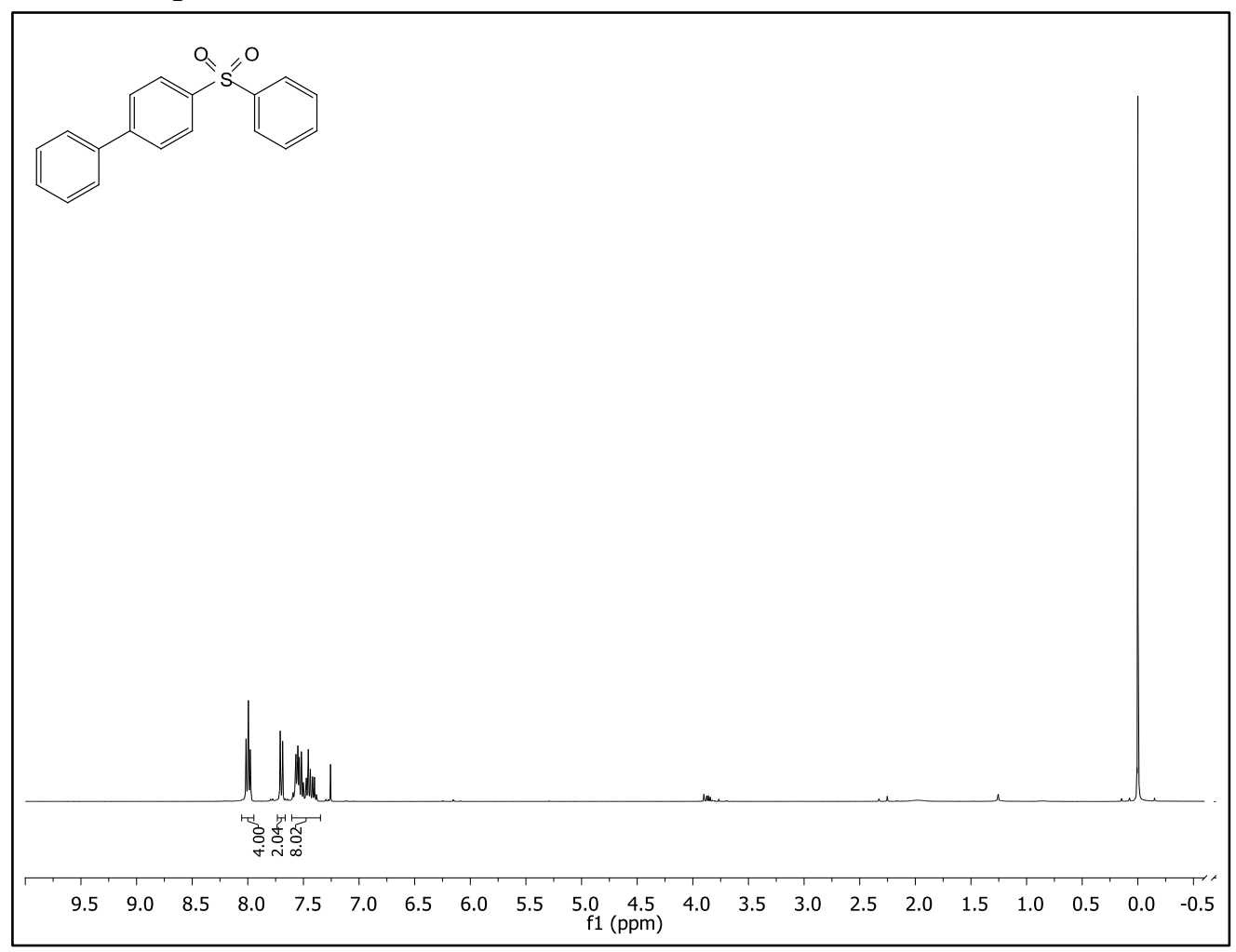

- ${ }^{13} \mathrm{C}$ NMR spectrum of 35 at $101 \mathrm{MHz}$ in $\mathrm{CDCl}_{3}$ at $298 \mathrm{~K}$

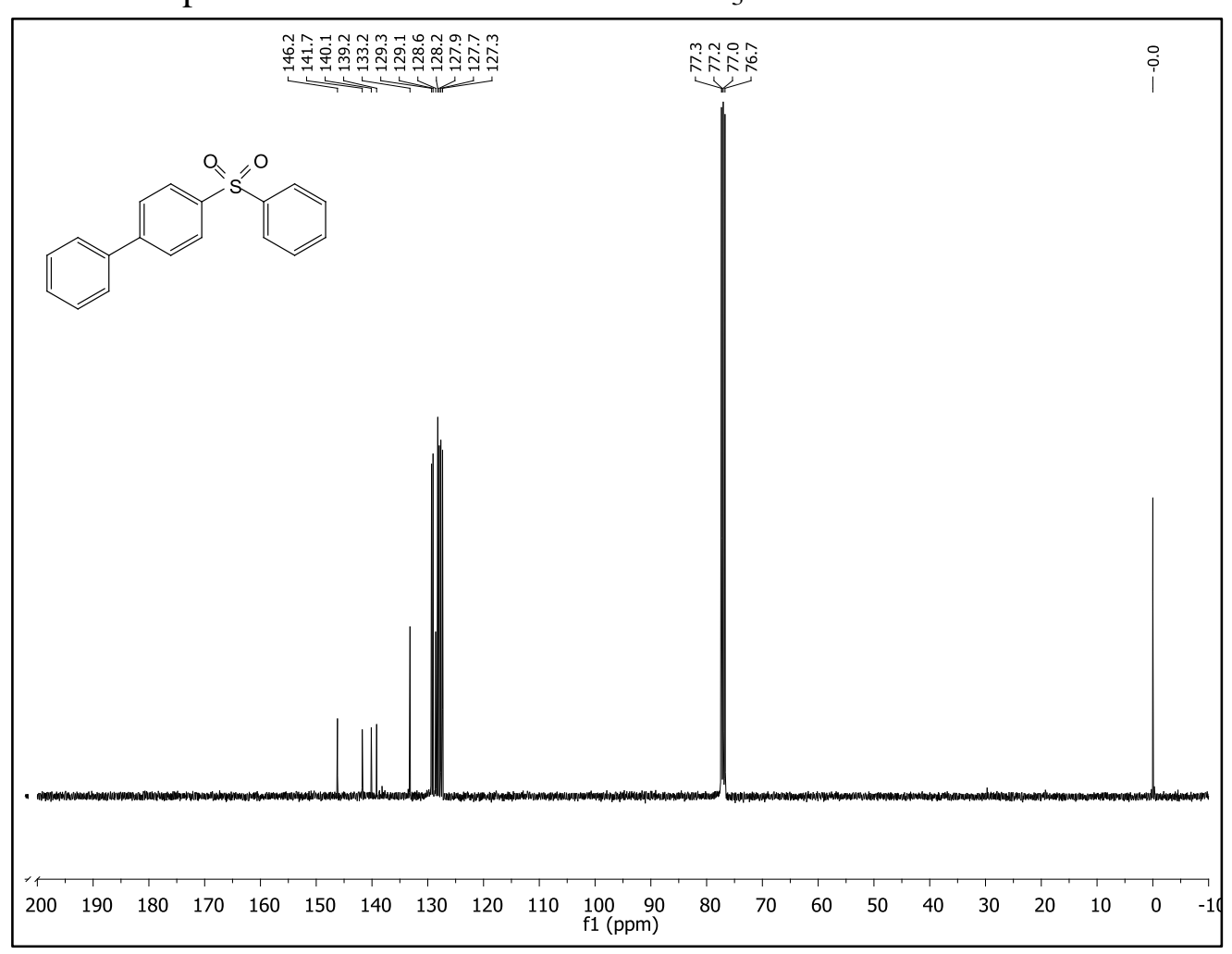


- ${ }^{1} \mathrm{H}$ NMR spectrum of $\mathbf{3 6}$ at $400 \mathrm{MHz}$ in $\mathrm{CDCl}_{3}$ at $298 \mathrm{~K}$

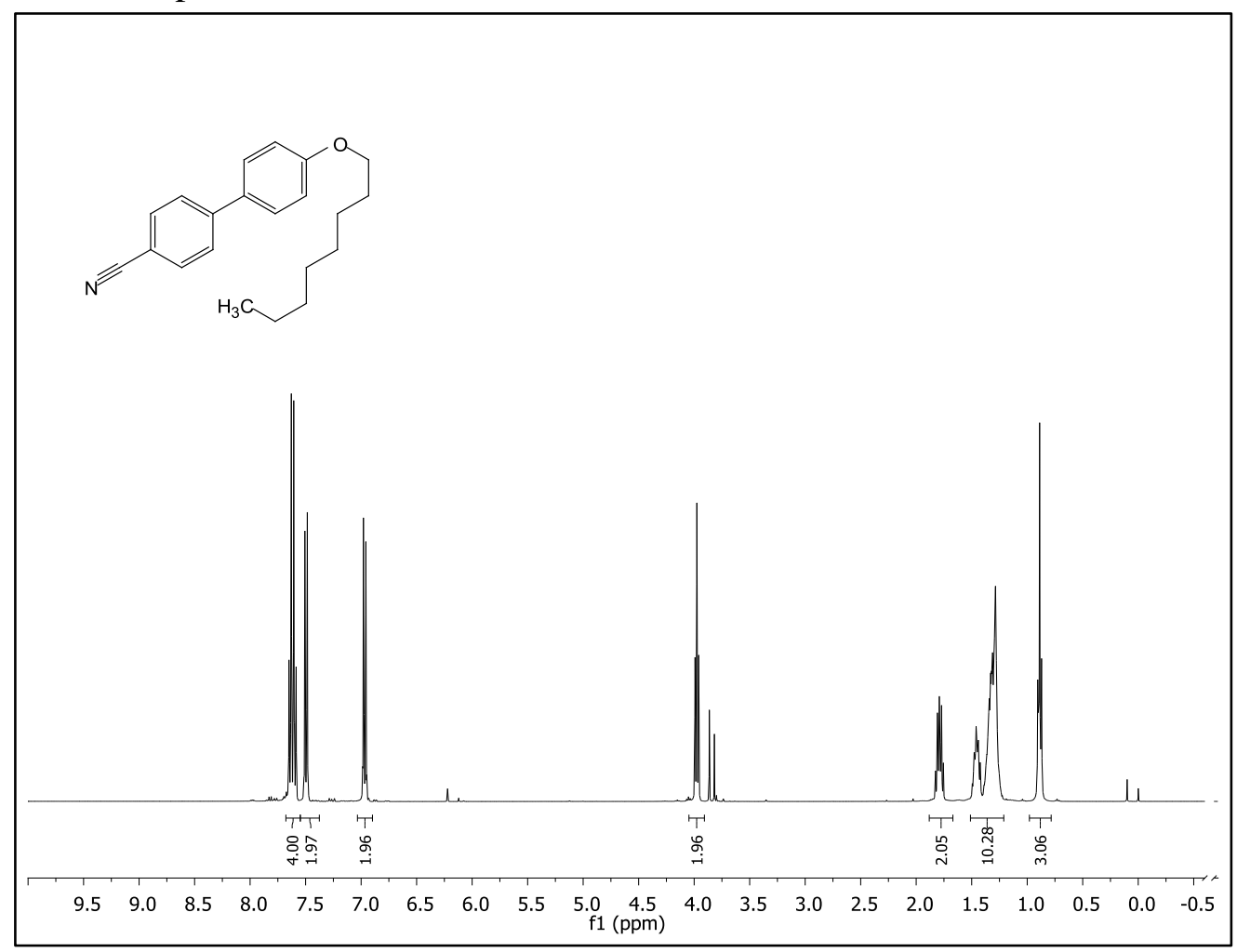

- ${ }^{13} \mathrm{C}$ NMR spectrum of 36 at $101 \mathrm{MHz}$ in $\mathrm{CDCl}_{3}$ at $298 \mathrm{~K}$

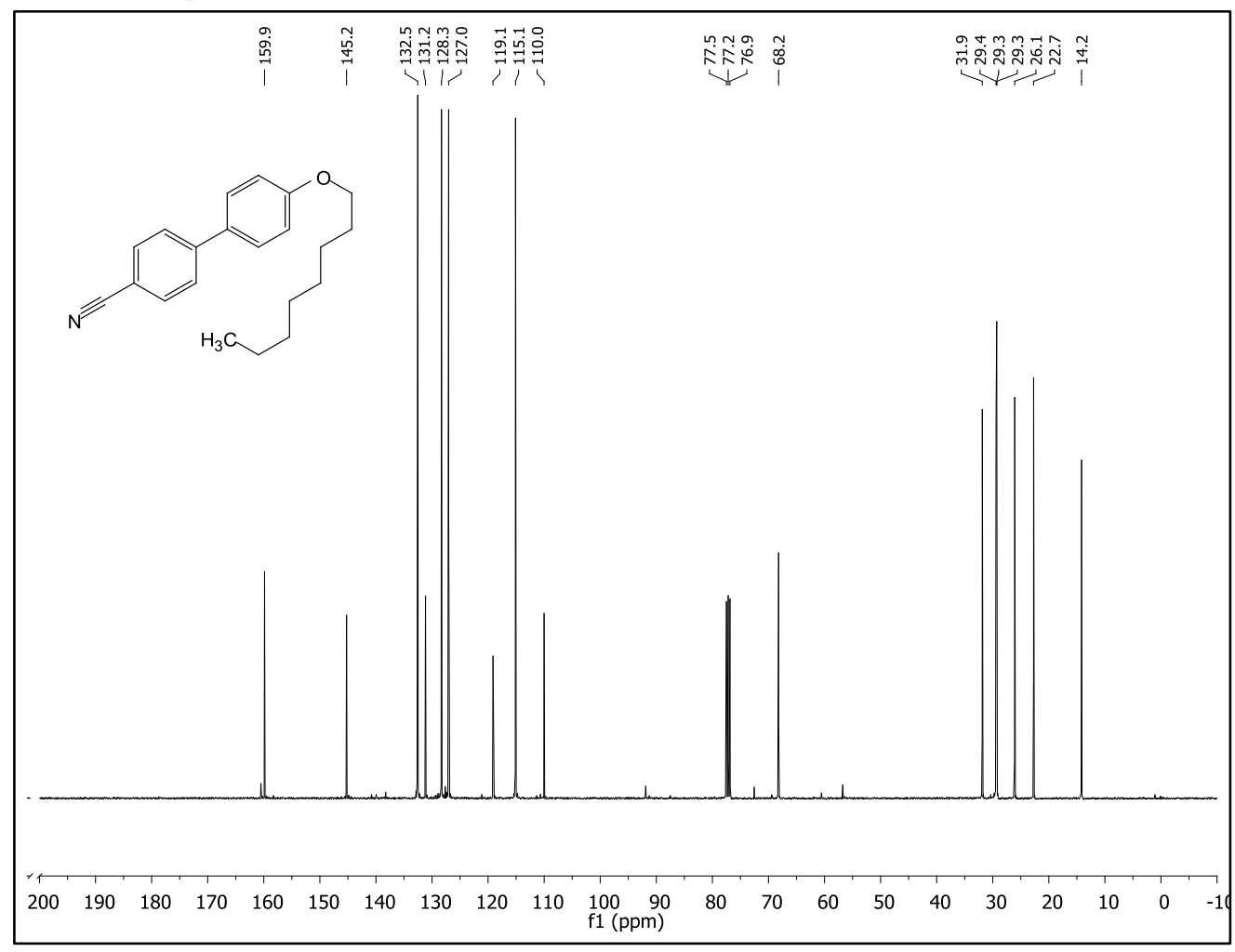

